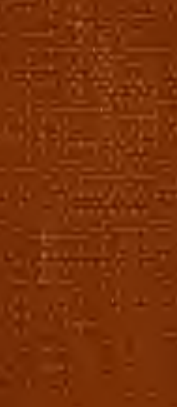

Q0.

W6.

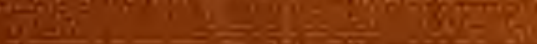

作
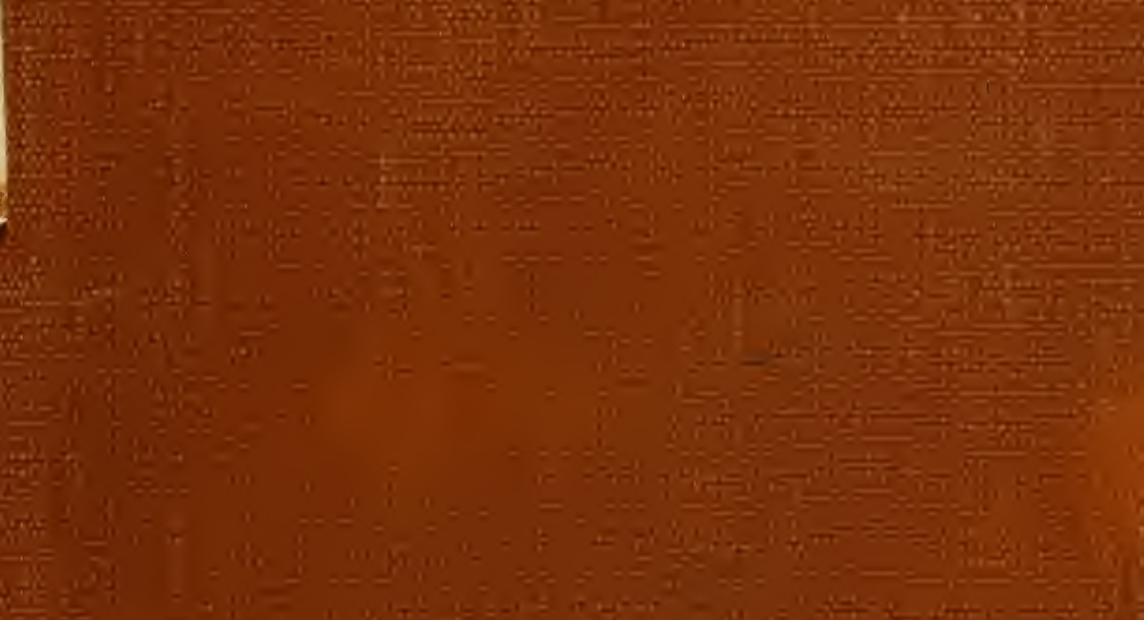

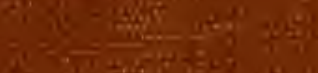

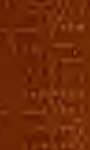

Mete

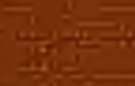

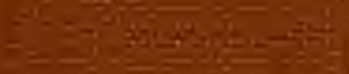

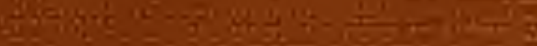

-

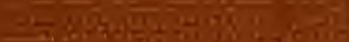

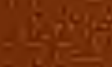

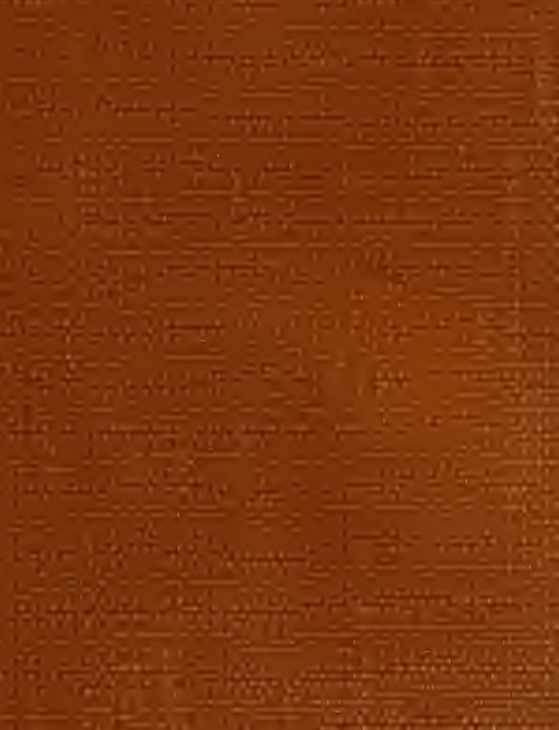




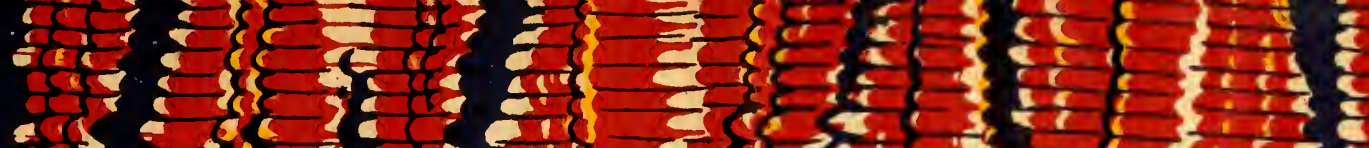
a.

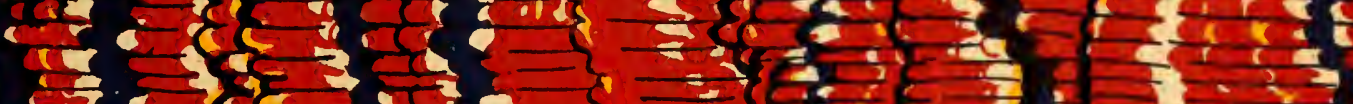

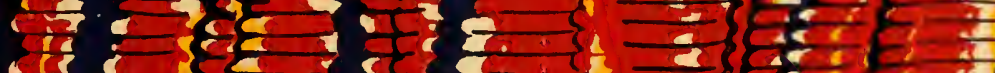

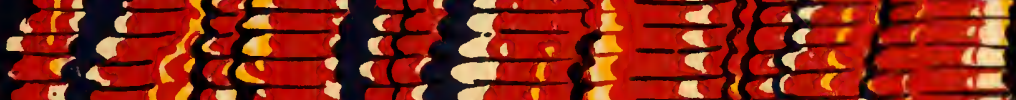

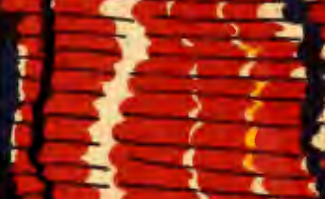

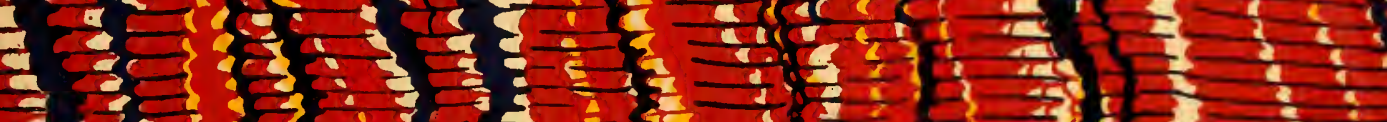

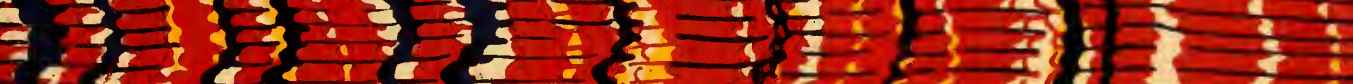

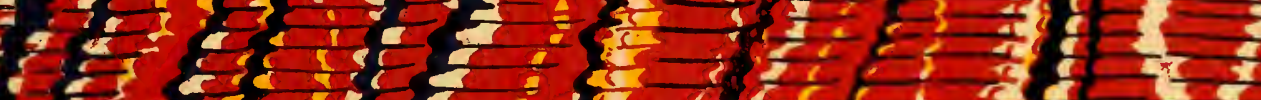

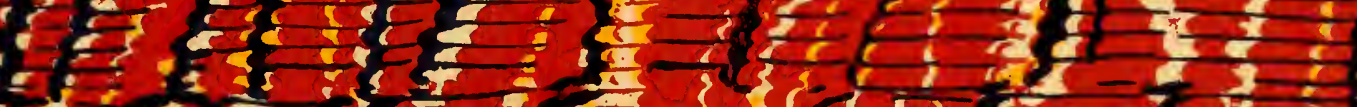

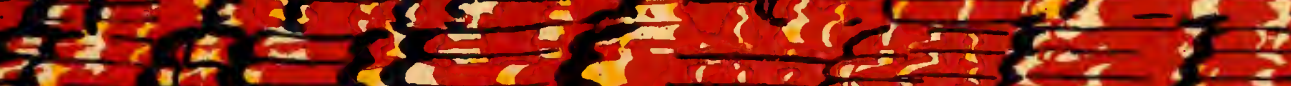

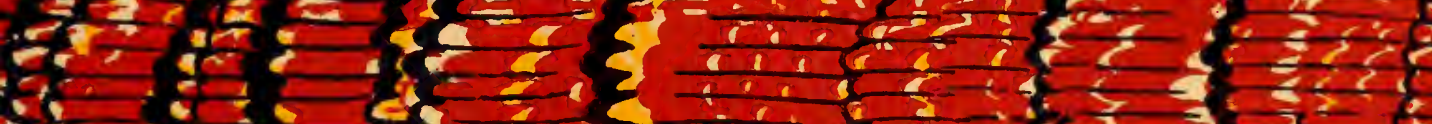

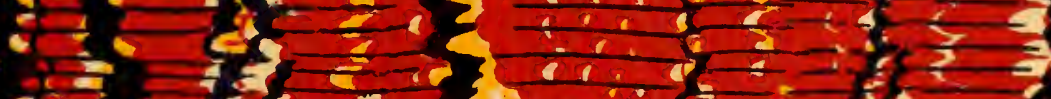

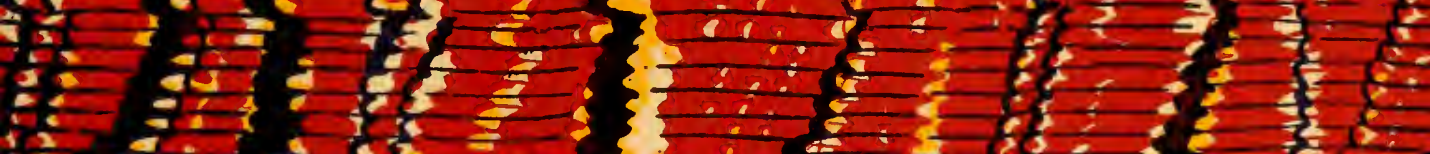

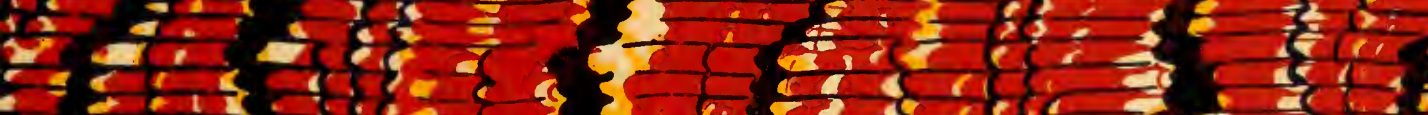

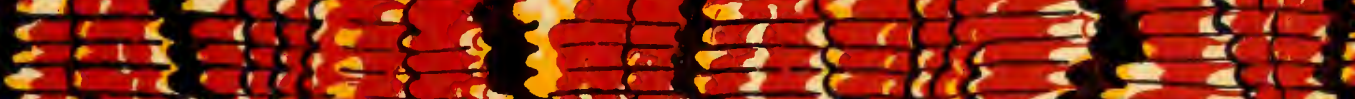

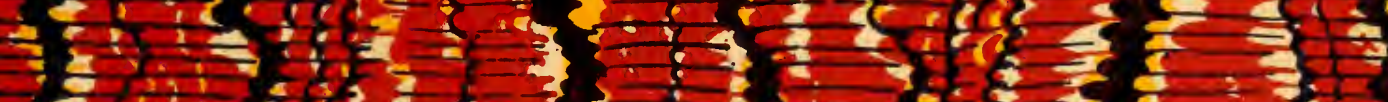

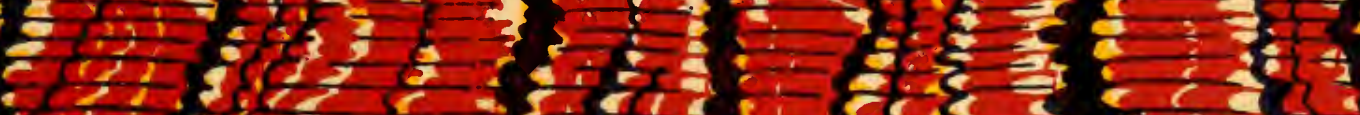

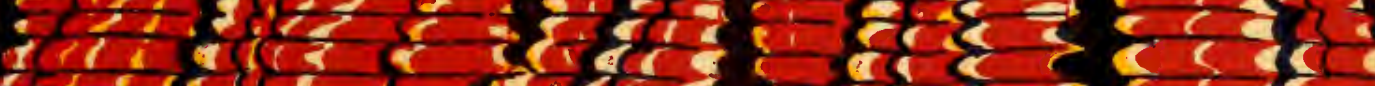

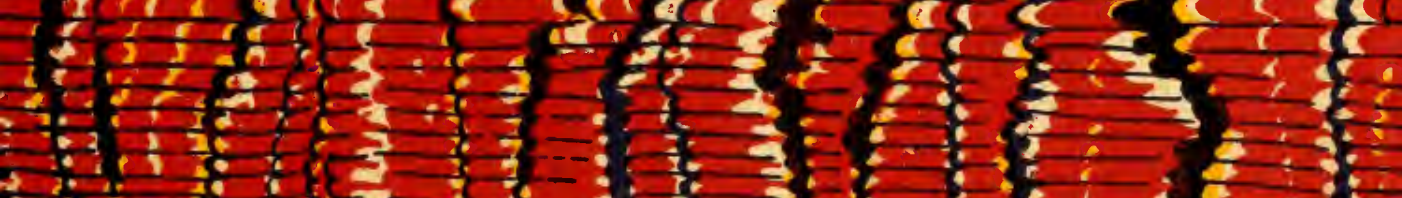

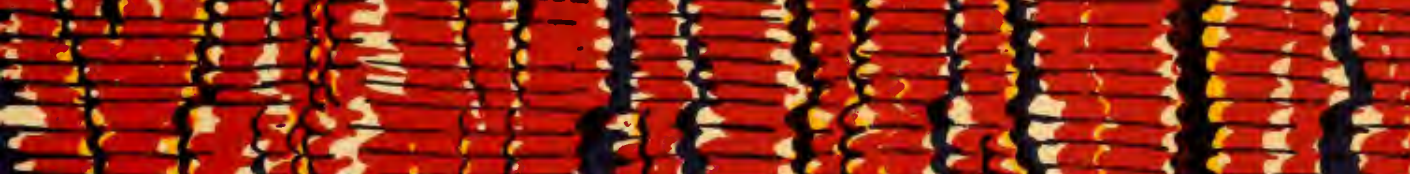

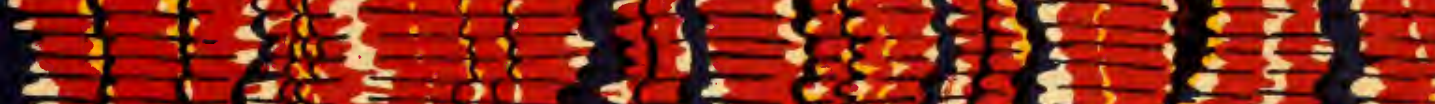

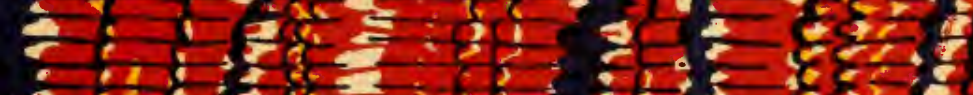

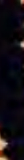

$\because 2 ; \frac{2}{2}+\frac{1}{2}=$

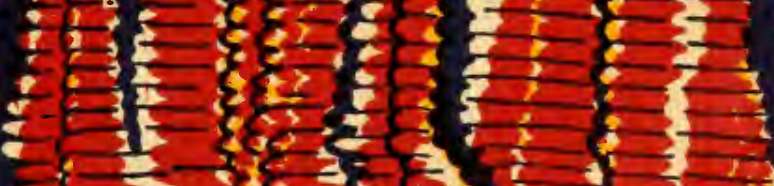

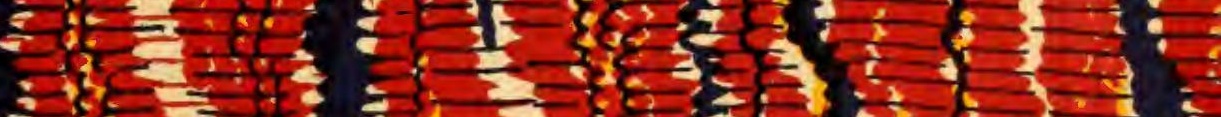

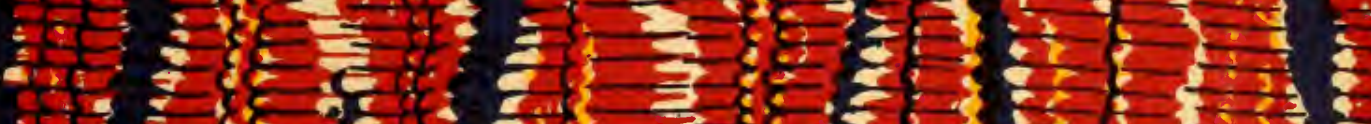

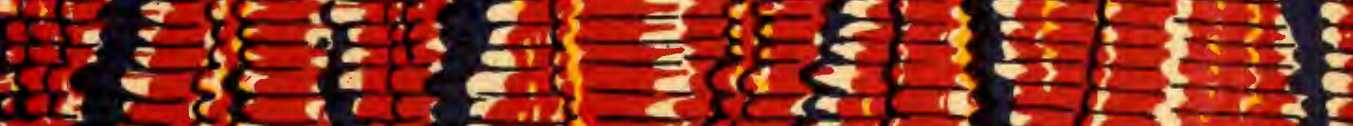
$\rightarrow 53$ its

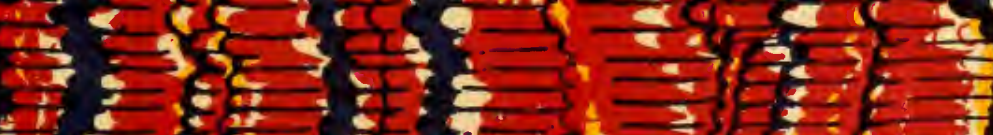

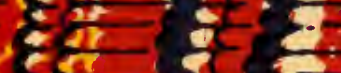

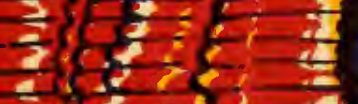

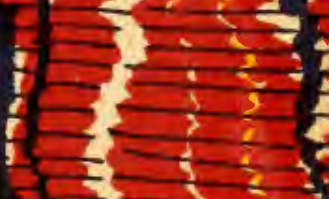

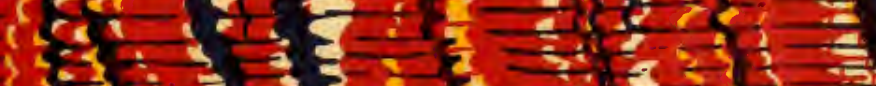

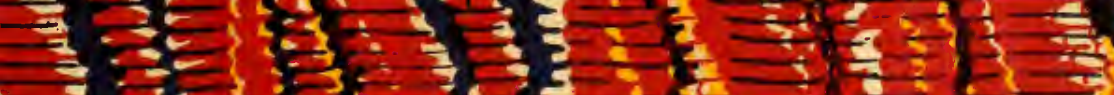
FELEDE 







\section{VARIATION AND CORRELATION IN THE CRAYFISH}

WITH SPECIAL REFERENCE TO THE INFLUENCE OF DIFFERENTIATION AND HOMOLOGY OF PARTS

BY

RAYMOND PEARL AND A. B. CLAWSON

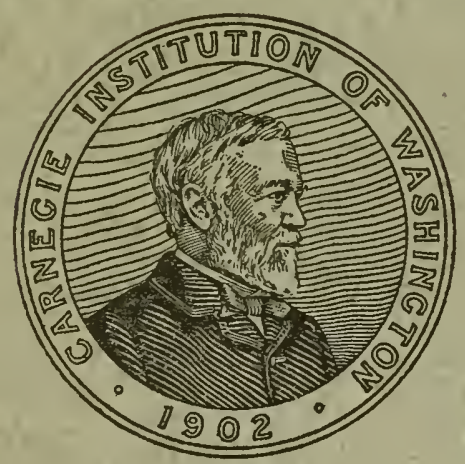

WASHINGTON, D. C.

Published by the Carnegie Institution of Washington 1907 



\section{VARIATION AND CORRELATION IN THE CRAYFISH}

WITH SPECIAL REFERENCE TO THE INFLUENCE OF

DIFFERENTIATION AND HOMOLOGY

OF PARTS

BY

RAYMOND PEARL AND A. B. CLAWSON

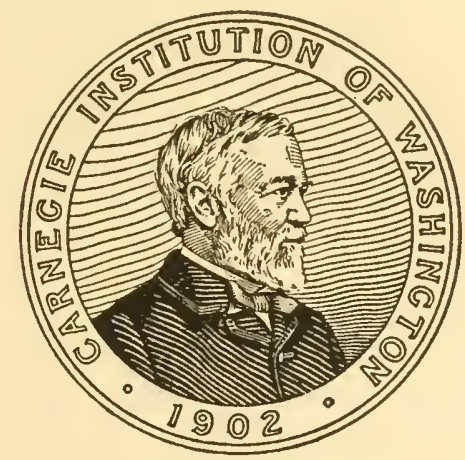

WASHINGTON, D. C.

Published by the Carnegie Institution of Washington 1907 
CARNEGIE INSTITUTION OF WASHINGTON Publication No. 64 


\title{
VARIATION AND CORRELATION IN THE CRAYFISH, WITH SPECIAL REFERENCE TO THE INFLUENCE OF DIFFERENTIA. TION AND HOMOLOGY OF PARTS.
}

\author{
By Raymond Pearl and A. B. Clawison.
}

\section{INTRODUCTION.}

The general purpose with which this study was undertaken was to investigate by biometrical analysis the laws of variation in a number of organs which, while serially homologous, were at the same time differentiated among themselves in varying degrees. Such systems of organs are of course well known. A very clear example is afforded by the appendages of a crustacean, say a decapod. In such an organism there is strict serial homology between the segments of the different appendages. At the same time, a given segment of any single appendage is distinctly differentiated from the homologous segments of the others. The primary and immediate aim of the present study was to obtain as definite answers as possible to the following two questions:

(I) What relation exists between the relative degree of variation exhibited by any particular organ or character and its degree of differentiation or specialization, as compared with other similar organs in a homologous series?

(II) What relation exists between degree of correlation on the one hand, and, on the other hand, the similarity of structure and position indicated in the homology of parts in such a series of organs as is presented, for example, by the segments of the crustacean appendage?

Naturally the data collected to answer these questions threw light on other problems of variation, which will be considered further on in the paper. Both of the main problems we had before us have been incidentally considered in several cases by earlier workers, but, so far as we are able to learn, no systematic investigation, aimed at their elucidation and working by quantitative metlods on a considerable number of characters of an organism, has ever been made. It seemed desirable that such an investigation should be undertaken. 
In looking about for an organism suitable for such a study, the common freshwater crayfish at once occurred to one as an especially favorable form. In the crayfish there is no doubt about the serial homology (attaching to the term the significance which it ordinarily has in comparative anatomy) of the several joints of the successive ambulatory appendages. The most anterior leg (the cheliped) is widely differentiated from the more posterior walking legs, among which as a class there is little differentiation. Thus we are enabled easily to compare the relative variability and correlation in slightly differentiated and greatly differentiated homologous parts. Further, the firm exoskeleton makes it possible to take measurements with a maximum of accuracy. Finally, it is possible to obtain fairly large numbers of adult individuals with relative ease.

The present paper forms one of a series in course of publication by one of the authors, all of which have as their general aim the analysis of the factors of variation and correlation, as a contribution toward the eventual determination of the fundamental physiological (morphogenetic) laws which underlie these phenomena. In different papers of the series the attempt has been made to analyze by experiment and observation, supplemented by biometrical methods, the influence of different factors on the degree and nature of the variation exhibited by particular sets of organs or characters. The number of factors which conceivably may play a part in influencing variation is of course very great. From the very complexity of the problem we are forced to the admittedly slow process of making detailed and thorough studies of but few of these factors at a time. The present paper deals with the influence on variation of two such conceivable factors, namely, the degree of differentiation or development of parts fundamentally similar in their structure, and the relationship between such parts expressed in the term "homology." In other papers of the series which either have appeared or will be published shortly other sets of factors have been considered. The underlying ideas which have been in the mind of the writer of this paper throughout the course of his work on variation are $(a)$ that the phenomena of continuous variation must themselves be thoroughly analyzed before we can get at the laws which underlie them, and (b) that the most certain way to make progress towards the desired goal is by following the method of quantitative analysis. As the work has progressed, the more firmly has the writer been convinced of the essential truth of these ideas. 
Having made clear the general problems with which this investigation has to do it will not be necessary to state here the specific subsidiary questions which we have attempted to answer. Instead these questions will be stated in the body of the paper in direct connection with the data bearing upon them.*

\section{MATERIAL.}

As material for this study a collection of crayfish belonging to the Zoölogical Museum of the University of Michigan was used. We have to thank Mr. C. C. Adams for kindly placing the material at our disposal. The collection included about 450 adult individuals of both sexes, all clearly belonging to the same species. The specimens were collected from the River Rouge, near Birmingham, Michigan, on July 24, 1903, by Mr. J. B. Field, and were by him presented to the University Museum. They may be considered to form a homogeneous sample of the crayfish population of that locality. The specimens belonged to the species Cambarus propinquus Girard. We have, then, a homogeneous sample of material belonging to the same species, all the individuals of which have probably been exposed to reasonably the same set of environmental factors during their development. In the collection males were about twice as numerous as females. We had at first intended to study the variation in both sexes, but on account of the relatively small number of the females, as well as for other reasons which need not be entered into, it was decided to confine the attention to the males. All specimens were discarded in which any one of the joints of the legs which were chosen for measurement was either lost or undergoing regeneration. There remained 283 normal males available for measurement. All these males measured belonged to the so-called "Form I." It was apart from the purpose of the present study to consider the relation of the dimorphism of the males in the genus Cambarus to variation, and hence only one form was used in the investigation. This dimorphism has been discussed by Hagen (1870), Faxon (1884), Harris (1901), and others.

* At this point I wish to acknowledge my great indebtedness to the Carnegie Institution of Washington for grants, during the tenure of which this work was done. It is impossible to make any adequate statement of the value of this aid in my biometric work. Under the best of conditions research in this field is very laborious and timeconsuming, and without adequate material facilities to lighten the burden of computation, and uninterrupted time for work, it is practically impossible to carry through any extensive plan of biometrical work in any reasonable length of time. It should be stated that I am alone responsible for the actual writing of this paper.-R. P. 
CHARACTERS STUDIED AND METHODS USED.

In choosing characters for measurement two somewhat conflicting things had to be kept in mind. In the first place, to get adequate evidence on the problems attacked it was necessary that several characters should be taken in each of several members of a homologous series of organs. In the second place, practical considerations with reference to the time which conld be given to the work demanded that the total number of measurements to be taken on each individual should not be too great. After careful consideration of the matter it was decided that the joints of the legs offered on the whole the best chance of getting light on the relation of variation to differentiation and homology. The legs are more satisfactory appendages to deal with than the maxillipeds, because of their greater size. Further, the morphological specialization of parts connected with the performance of special functions does not extend so far in the case of the legs.

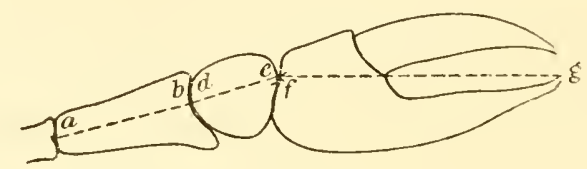

Frg. 1,-Outline of leg of crayfish bearing great chela.

It did not appear necessary for our purposes to take measurements of the same characters on both sides of the body. Consequently all measurements of bilateral characters were taken on the organs of the right side of the animal only. It will be understood without further reference to the matter that throughout the paper all statements regarding the joints of the legs are based on data from the appendages on the right side of the body. On each of the first three legs (i.e., the cheliped and the first two walking legs) the length of each of the three distal joints was measured. These distal joints were taken rather than more proximal ones, because of the greater degree of differentiation which they present. In addition to the measurements on the legs, the length of the cephalothorax and the breadth of the head were recorded. The following detailed statements in connection with fig. 1 will make plain the exact character of the measurements taken.

For verbal convenience we shall throughout the paper use the following conventions in referring to the different legs: The leg bearing the great chela will be designated as "leg I ;" the first walking leg as "leg II;" and the second walking leg as "leg III." 
Using the preceding terminology, the measurements made may be listed as follows:

(1) Length of the meripodite of leg I, from the edge of its proximal dorsal process for articulation with the ischiopodite to the distal edge of the joint on the median line. (Fig. 1, $a-b$.)

(2) Length of the meripodite of leg II. Measurements from the points corresponding to those given in (1).

(3) Length of the meripodite of leg mIr. Measurements from the points corresponding to those given in (1) and (2).

(4) Length of the carpopodite of leg I, from the proximal dorsal edge to the end of the distal dorsal process, where this joint articulates with the propodite. (Fig. 1, d-e.)

(5) Length of the carpopodite of leg II. Measurements from the points corresponding to those given in (4).

(6) Length of the carpopodite of leg III. Measurements from the points corresponding to those given in (1) and (5).

(7) Length of the propodite of leg I, from the proximal dorsal process where it articulates with the carpopodite to the extreme distal end. (Fig. 1, $f-g$.)

(8) Length of the propodite of leg II. Measurements from the points corresponding to those given in (7).

(9) Length of the propodite of leg IrI. Measurements from the points correspond. ing to those given in (7) and (8).

(10) Length of the cephalothorax, from the tip of the rostrum to the posterior margin on the dorsal median line.

(11) Breadth of the head, between symmetrical points on either side in the cervical groove just in front of the two lateral spines.

The dimensions were taken by means of a pair of fine-pointed dividers. They were then read off on a steel scale graduated to fifths of a millimeter. All readings were made with the aid of a hand lens. The records were made to tenths of a millimeter, and may certainly be considered accurate to fifths.

In reducing the material we have determined the correlation between every possible pair of characters. Since we are dealing with eleven characters, the number of possible pairs is $\frac{11 \times 10}{2}$, or 55. From this material we are enabled to analyze in detail the phenomena of correlation in the eleven characters enumerated.

In calculating the constants of the frequency distributions we have throughout used Sheppard's corrections for the moments. The work of computation was much facilitated by the use of a large Brunsviga arithmometer. 


\section{GENERAL DISCUSSION.}

The measurements upon which this work is based are given in the form of correlation tables in the Appendix (tables 22 to 32). The first thing which impresses one in studying these tables is the fact that we are dealing here with very high correlations, and almost perfect linearity of the regression. High correlation denotes, of course, a relatively great degree of constancy in the proportionality of the correlated parts. Our tables show that in the crayfish, so far as the range of the characters we have considered is concerned, there is very little variation in the array of one variable associated with a given type of the other. This means that there is a very strong tendency for definite and particular conditions of the different characters to be associated together. The fact that the characters which were chosen for this study are generally so highly correlated makes them especially favorable for the discussion of our problems, since high values for the coefficients of correlation give us low values for the probable errors, and hence we shall be able to estimate the probable significance of small differences with considerable accuracy.

It seems desirable to collect together in one place the constants measuring the degree of variation and correlation exhibited by the characters studied. These constants are given in tables 1 and 3. These form the fundamental reference tables; the data from them will be used in succeeding portions of the paper, to answer special problems. Table 1 gives the following variation constants for the distribution of each of the eleven characters: Mean, mode, standard deviation, coefficient of variation, moment coefficients, $\beta_{1}, \beta_{2}$, kurtosis $\left(\beta_{2}-3\right)$, skewness, and modal divergence. The unit for the "physical" constants is $1 \mathrm{~mm}$., while for the algebraical constants the unit is the unit of grouping, the value of which in millimeters is given in the second column of the table.

From table 1 we note at once the following general facts regarding variation in the characters under consideration:

(a) The relative variability in proportion to the size of the thing varying is of roughly the same order of magnitude in practically all the characters studied. With the single exception of the great chela (propodite of $\operatorname{leg} \mathrm{I}$ ), the coefficients of variation all fall between 11 and 14.3 per cent. The great chela is very significantly more variable than any of the other characters. It is of some interest to compare our results on this point with some of the data which have been given by other workers for variation in other Crustacea. Table 2 makes possible such comparison, and from the data there given one would conclude that in the dimensions of the body the crayfish is proportionately a much less variable form than is Eupagurus, and slightly more variable than Gelasimus. 
TABLE 1.-Constants of variation in the crayfish.

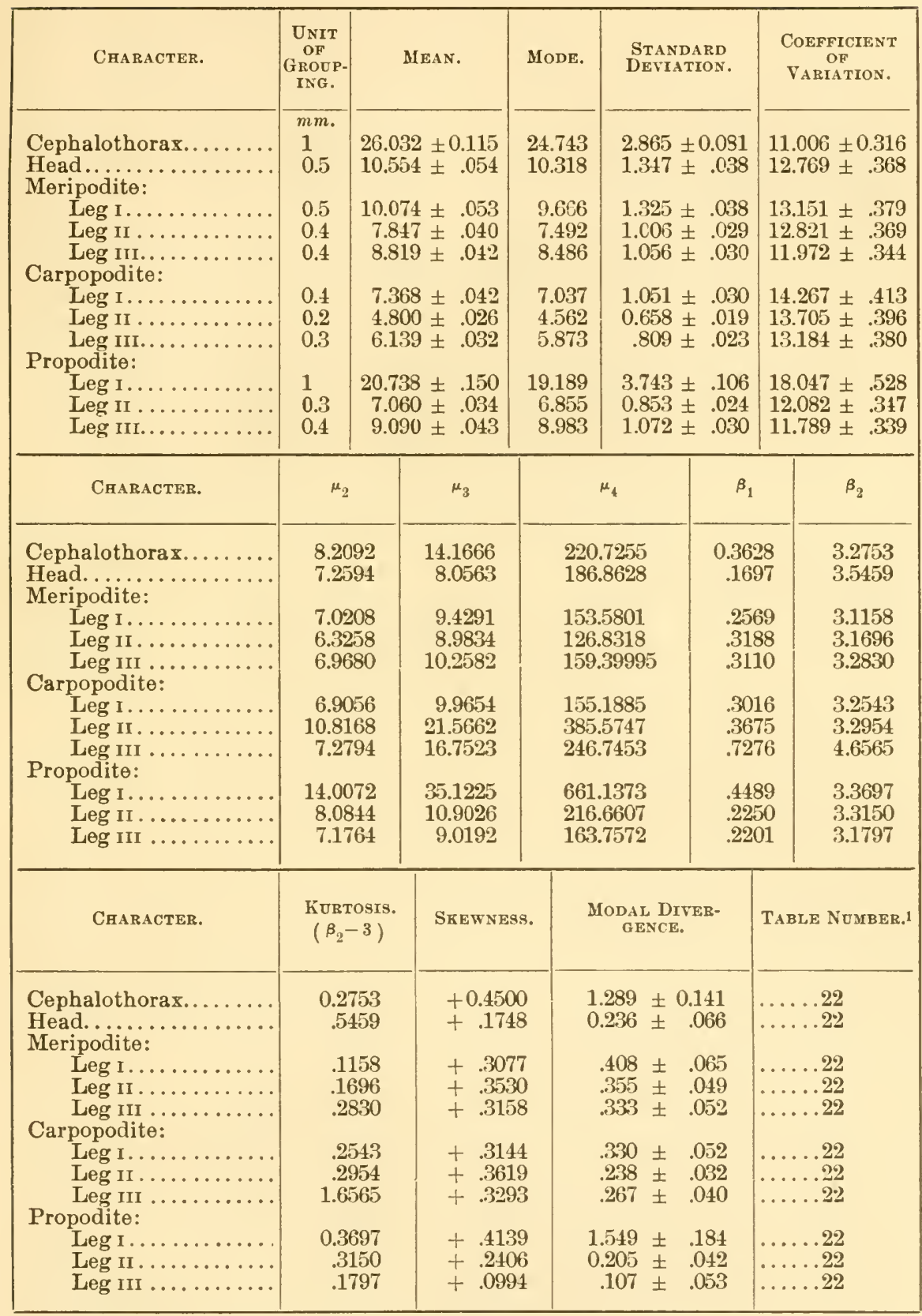

1 In this column are given the numbers of the correlation tables where will be found the dis. tributions from which the constants of table 1 are deduced. 
TABLE 2.-Coefficients of variation in Crustacea.

\begin{tabular}{|c|c|c|c|}
\hline Organism. & Character. & $\begin{array}{c}\text { COEFFICIENT } \\
\text { OF VARIATION. }\end{array}$ & AUtновIтY. \\
\hline 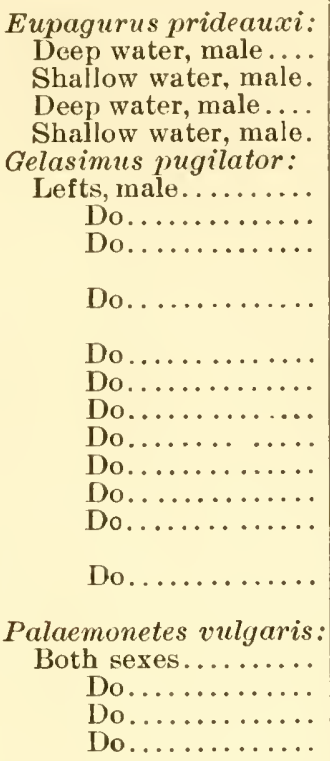 & 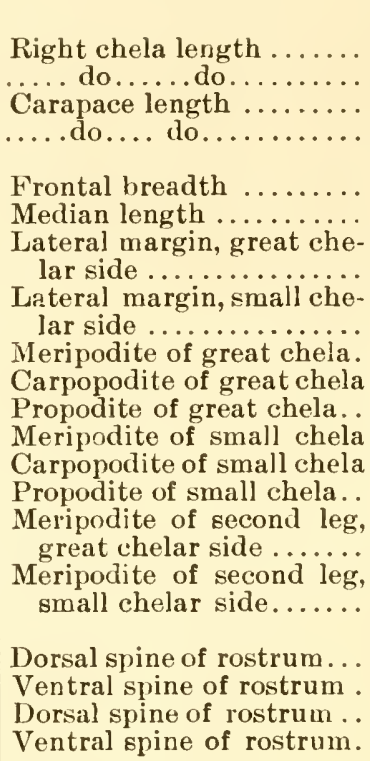 & $\begin{array}{c}26.313 \pm 0.609 \\
23.434 \pm .502 \\
19.446 \pm .438 \\
17.746 \pm .372 \\
7.471 \\
7.598\end{array}$ & $\begin{array}{c}\text { Schuster (1903) } \\
\text { Do. } \\
\text { Do. } \\
\text { Do. } \\
\text { Yerkes (1901) } \\
\text { Do. } \\
\text { Do. } \\
\text { Do. } \\
\text { Do. } \\
\text { Do. } \\
\text { Do. } \\
\text { Do. } \\
\text { Do. } \\
\text { Do. } \\
\text { Do. } \\
\text { Do. }\end{array}$ \\
\hline
\end{tabular}

(b) The variation in all the characters shows a distinct skewness in the positive direction. The value of the constant measuring the skewness ranges from 0.10 to 0.45 , being lowest in the case of the propodite of leg III, and highest for the length of the cephalothorax. That the distributions all deviate significantly from the symmetrical conditions given by the normal or Gaussian law is evident if we compare the values of the skewness and the modal divergence with the probable errors of these constants for the normal curve. In a normal distribution where $N$, the total number of individuals, is 283 we have

$$
\text { Probable error of skewness }= \pm 0.0491
$$

The probable error of the "modal divergence" for each case, on the assumption of normality, is given in table 1 . From these values we see that in only one case (the propodite of leg III) is the value of the skewness or the modal divergence less than three times the probable error. For this character the constant is in each case almost exactly twice the probable error. Now, if these distributions were to be regarded 


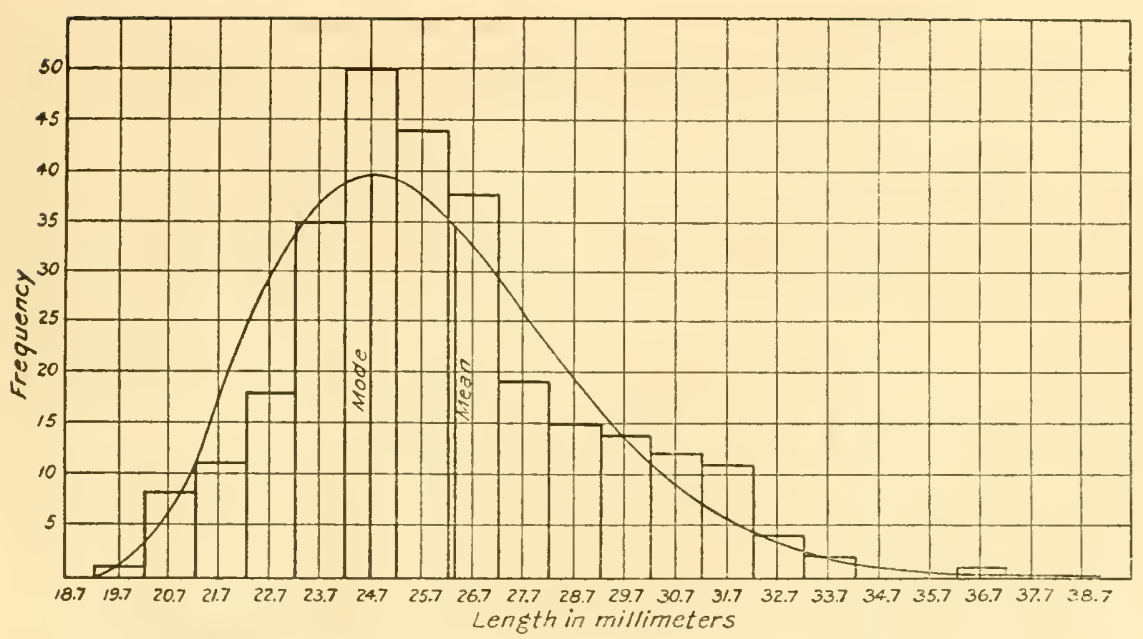

FIG. 2,--Frequency polygon and its fitted curve for variation in length of cephalothoras.

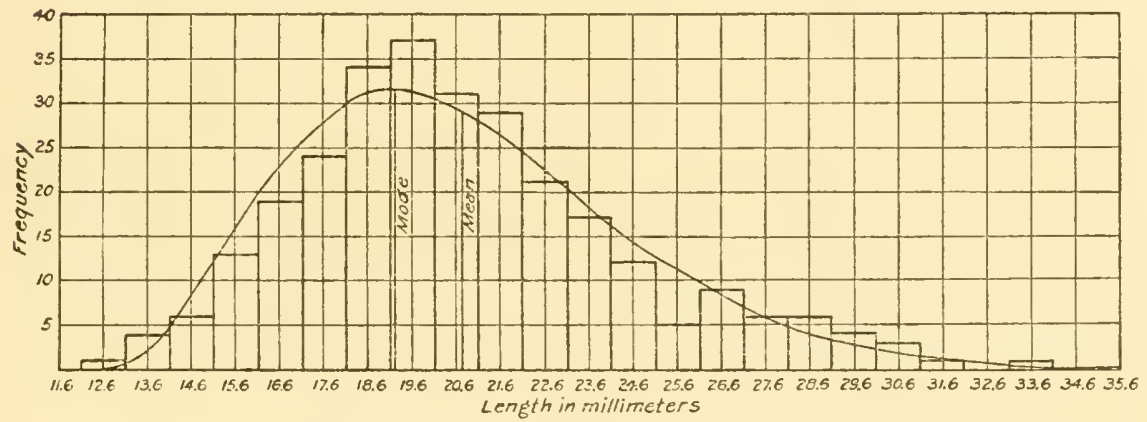

FIG. 3.-Frequency polygon and its fitted curve for variation in propodite of leg I.

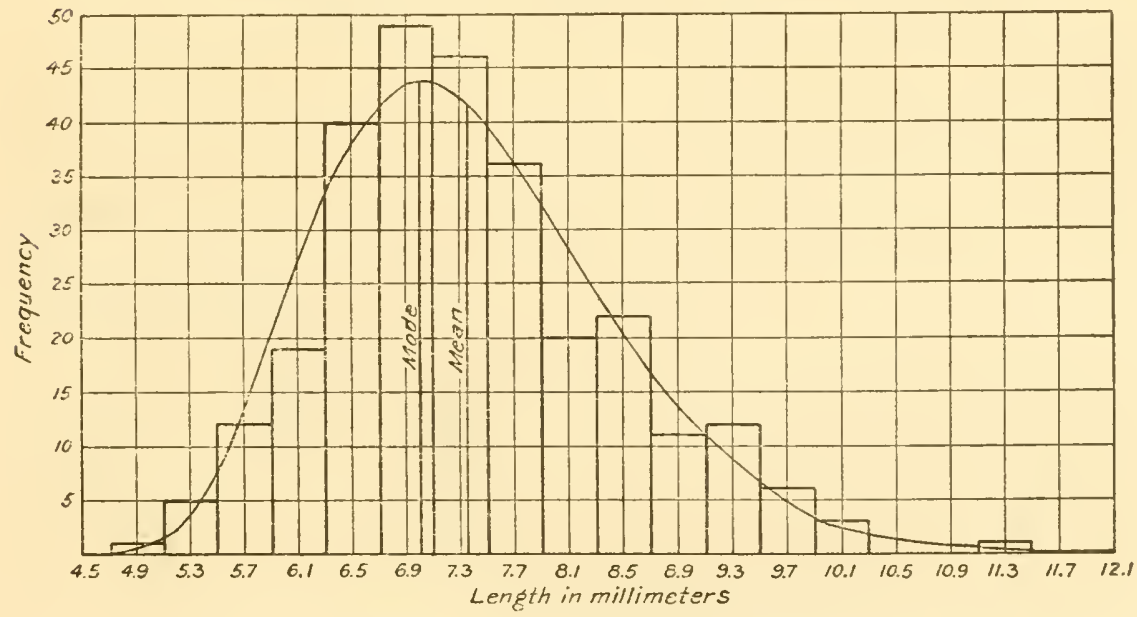

Fig. 4.- Erequency polygon and its fitted curve for variation in carpopodite of leg $\mathrm{I}$. 
as following the normal law within the limit of errors due to random sampling, neither of these constants should differ from zero by at most more than twice the probable errors given. But the values of the constants actually obtained, with a single exception, greatly exceed this limit. Hence there can be no doubt that we are dealing here with significantly skew variation. In order to make plain the character of these distributions with which we are dealing, figs. 2,3 , and 4 , have been prepared. They show the frequency polygons and their fitted curves for the variation in the following characters: Fig. 2, length of cephalothorax; fig. 3, propodite of leg I; fig. 4, carpopodite of leg I.

The curve for each of these three polygons is of Pearson's Type I, having the range limited in both distributions. The equations to the curves are as follows:

$$
\begin{aligned}
& \text { Length of cephalothorax, } y=40.0539\left(1+\frac{x}{5.7651}\right)^{3.3037}\left(1-\frac{x}{27.9892}\right)^{16.0392} \\
& \text { Propodite of leg I, } \quad y=30.9939\left(1+\frac{x}{6.5790}\right)^{2.6248}\left(1-\frac{x}{35.9791}\right)^{14.3542} \\
& \text { Carpopodite of leg I, } \quad y=43.3056\left(1+\frac{x}{6.2462}\right)^{4.6647}\left(1-\frac{x}{30.6862}\right)^{22.9167}
\end{aligned}
$$

It is evident from the diagrams that the curves give excellent graduations, quite as good as could be expected when dealing with less than 300 individuals in the observational series. There are some points regarding the curves which need especial mention. In the first place, we note from the equations that the theoretical range is large in each case. The actual values are as follows:

Length of cephalothorax, theoretical range $=33.7542 \mathrm{~mm}$.

Propodite of leg $\mathrm{I}$, theoretical range $\quad=42.5581 \mathrm{~mm}$.

Carpopodite of leg $\mathrm{I}$, theoretical range $\quad=14.7730 \mathrm{~mm}$.

These ranges evidently exceed considerably those observed, but this excess is practically entirely due to the extreme "tailing out" of the

\begin{tabular}{|c|c|c|c|c|}
\hline \multirow{2}{*}{ Character. } & \multicolumn{2}{|c|}{ Lower (-) Exd of RaNGe. } & \multicolumn{2}{|c|}{ UPPER (+) END of RaNGE. } \\
\hline & Observed.1 & Theoretical. & Observed.1 & Theoretical. \\
\hline & $\begin{array}{l}m m . \\
19.7\end{array}$ & $\begin{array}{c}m m . \\
18.978\end{array}$ & $\begin{array}{l}m m . \\
36.7\end{array}$ & $\begin{array}{c}m m . \\
52.732\end{array}$ \\
\hline Propodite of leg I... & 12.6 & 12.610 & 33.6 & 55.168 \\
\hline Carpopodite of $\operatorname{leg} \mathrm{I}$. & 4.9 & ${ }^{2} 4.539$ & 11.3 & ${ }^{2} 19.312$ \\
\hline
\end{tabular}
theoretical curve toward large values, i. e., on the + side of the mode. The truth of this statement is shown by the values of the following table:

1 The values in these columns are the centers of the extreme classes of the observed ranges.

2 It should be remembered that the apparent discrepancy between these values and those of $a_{1}$ and $a_{2}$ as given in the third oquation supra arises from the fact that the constants of the equation are given in units of grouping, while here they are in millimeters. 
No great stress is to be laid on the great overestimation by the theoretical curves of the ranges on the plus side, for two reasons. On the one hand, the constant $a_{2}$, which gives the range on the plus side of the mode, is subject to a large probable error. On the other hand, the total frequency beyond the observed upper limit of the range as given by the theoretical curve is so small as to be entirely negligible for all practical purposes. This will be evident from mere inspection of the ends of the curves, without going into the figures to prove it.

Inspection of the curves leaves no doubt as to the substantial deviation of the distributions from the symmetrical condition of the normal curve. That the skewness is positive for all the characters studied is directly connected with the fact that there is a very high degree of correlation between these characters. Given a positive skewness for one character, say length of cephalothorax, and we should expect that all other characters of the same organism which are closely correlated in size with the cephalothorax would also exhibit positive skewness. This is evident if we consider that positive skewness in the character mentioned merely means that there are more individuals with the cephalothorax larger than the modal condition than there are individuals with it smaller than the mode. But if deviations from the mode in cephalothorax length have associated with them corresponding deviations in the same direction of the other size characters, clearly we should expect a similar sort of skewness in the frequency distributions of these other characters. In the present case we actually do find a very high degree of correlation or association existing between the different pairs, and hence that all should show skewness in the same direction is no more than is to be expected.

The explanation of the fact that the direction of the skewness is positive is possibly in part that individuals in different molts were included in the sample. This, however, can at most account for only a minor part of the observed condition. It seems to us idle to speculate as to the fundamental causes concerned in the production of skew variation in cases of this kind. We can only hope to determine them by experimental investigations conducted rad hoc.

(c) The kurtosis is in every case positive, or, in other words, $\beta_{2}>3$. In order to get an idea of the relative significance of this constant it is necessary to compare the value of $\beta_{2}-3$ with the probable error of $\beta_{2}$ for the normal curve. Working from the well-known formula we have, when $N=283$,

Probable error of $\beta_{2}= \pm 0.1564$ 
We see at once that in the case of the distributions for breadth of head and for the length of the carpopodite of leg III, there is a certainly significant deviation from the mesokurtic condition of the normal curve. The distributions for the propodites of legs I and II are probably significantly different from the condition of mesokurtosis. In the other cases the values of $\beta_{z}-3$ are less than twice the probable error and hence taken singly would have to be considered as probably not significant. Due weight must, however, be given to the fact that all the distributions show deviations from mesokurtosis in the same direction.

(d) Putting all the data together, we may safely conclude that the continuous variation in the characters of the crayfish which we have studied can not be adequately described by the normal or Gaussian curve. Both in respect to the symmetry of the variation about the mean or modal condition and in respect to the kurtosis the crayfish distributions deviate in a uniform manner from the normal curve. They demand skew curves for graduation.

We have in table 3 the coefficients of correlation, together with their probable errors, for every possible pair of the eleven characters studied. It is at once evident that we are dealing here with very high correlations. The lowest coefficient in the table is 0.84 , and from this the values run up to as high as 0.973 . These high correlations are in accord with what has been found by other workers who have studied correlation in other Crustacea. (Cf. Yerkes, 1901, and Schuster, 1903, for example.) The correlations between the different characters of the crayfish here studied are of the same order of magnitude as has generally been found for the correlation between bilaterally homologous organs or characters.*

In order to show graphically the closeness to linearity of the regressions between these different characters of the crayfish we have prepared the diagrams shown in figs. 5 and 6 . Fig. 5 shows the regression of the length of the propodite of leg I on the length of the cephalothorax, and fig. 6 the regression of the length of the meripodite of leg III on the length of the meripodite of leg $\mathrm{I}$. These two cases were taken at random merely as samples of what holds generally for all the other characters studied.

* Cf., for example, a table of the coefficients for such bilateral characters given as table III in Davenport (1903). 
TABLE 3.-Coeficients of correlation in the crayfish.

\begin{tabular}{|c|c|c|c|c|}
\hline Character. & Cephalothorax. & HEAD. & $\begin{array}{l}\text { MERIPODITE OF } \\
\text { LEG I. }\end{array}$ & $\begin{array}{l}\text { MERIPODITE OF } \\
\text { LEG II. }\end{array}$ \\
\hline $\begin{array}{l}\text { Cephalothorax } \\
\text { Head }\end{array}$ & \multirow{2}{*}{$\begin{array}{c}1 \\
0.9358 \pm 0.0050\end{array}$} & $0.9358 \pm 0.0050$ & \multirow{2}{*}{$\begin{array}{r}0.9627 \pm 0.0029 \\
.9282 \pm .0056\end{array}$} & $0.9314 \pm 0.0053$ \\
\hline Meripodite: & & \multirow[b]{2}{*}{$.9282 \pm .0056$} & & $.9184 \pm .0063$ \\
\hline Leg I ..... & $.9627 \pm .0029$ & & 1 & $.9665 \pm .0026$ \\
\hline Leg I & \multirow{2}{*}{$\begin{array}{ll}.9314 \pm & .0053 \\
.9582 \pm & .0033\end{array}$} & \multirow{2}{*}{$\begin{array}{ll}.9184 \pm & .0063 \\
.9233 \pm & .0059\end{array}$} & $.9665 \pm .0026$ & 1 \\
\hline Leg III & & & $.9686 \pm .0025$ & $.9729 \pm .0021$ \\
\hline Carpopodite: & \multirow{3}{*}{$.9485 \pm .0040$} & \multirow{2}{*}{$.9156 \pm .0065$} & & \\
\hline Leg I...... & & & $.9588 \pm .0032$ & $.9502 \pm .0039$ \\
\hline Leg II ... & & \multirow{2}{*}{$\begin{array}{ll}.8753 \pm & .0094 \\
.8395 \pm & .0118\end{array}$} & $.8913 \pm .0080$ & $.9083 \pm .0070$ \\
\hline Propodite: & \multirow{3}{*}{$\begin{array}{l}.9349 \pm .0051 \\
.9535 \pm .0036\end{array}$} & & $.8602 \pm .0101$ & $.8632 \pm .0102$ \\
\hline & & $.9106 \pm .0068$ & $.9439 \pm .0044$ & $.9440 \pm .0044$ \\
\hline Leg I & & \multirow{2}{*}{$.9304 \pm .0054$} & $.9578 \pm .0033$ & $.9696 \pm .0024$ \\
\hline Leg III. & $.9525 \pm .0037$ & & $.9579 \pm .0033$ & $.9559 \pm .0035$ \\
\hline Character. & $\begin{array}{l}\text { MERIPODITE OF } \\
\text { LEG III. }\end{array}$ & $\begin{array}{c}\text { CARPOPODITE OF } \\
\text { LEG I. }\end{array}$ & $\begin{array}{c}\text { CA RPOPODITE OF } \\
\text { LEQ II. }\end{array}$ & $\begin{array}{c}\text { CARPOPODITE OF } \\
\text { LEG III. }\end{array}$ \\
\hline Cephalothorax & \multirow{2}{*}{$\begin{array}{c}0.9582 \pm 0.0033 \\
.9233 \pm .0059\end{array}$} & \multirow{2}{*}{$\begin{array}{c}0.9485 \pm 0.0040 \\
.9156 \pm .0065\end{array}$} & $0.8948 \pm 0.0080$ & \multirow{2}{*}{$\begin{array}{r}0.8590 \pm 0.0105 \\
.8395 \pm .0118\end{array}$} \\
\hline Head.... & & & $.8753 \pm .0094$ & \\
\hline $\begin{array}{l}\text { Meripodite } \\
\text { Leg I... }\end{array}$ & \multirow{2}{*}{$\begin{array}{ll}.9686 \pm & .0025 \\
.9729 \pm & .0021\end{array}$} & \multirow{2}{*}{$\begin{array}{l}.9588 \pm .0032 \\
.9502 \pm .0039\end{array}$} & $8943+0080$ & \multirow{3}{*}{$\begin{array}{l}.8652 \pm .0101 \\
.8632 \pm .0102 \\
.8742 \pm .0095\end{array}$} \\
\hline Leg II. & & & $.9083 \pm .0070$ & \\
\hline Leg III... & & $.9601 \pm .0031$ & $.9021 \pm .0075$ & \\
\hline Carpopodite: & \multirow[b]{2}{*}{$.9601 \pm .0031$} & & & \\
\hline Leg I....... & & 1 & $.9069 \pm .0071$ & $.8685 \pm .0099$ \\
\hline Leg I & $.9021 \pm .0075$ & $.9069 \pm .0071$ & som & $.8888 \pm .0084$ \\
\hline $\begin{array}{l}\text { Leg I } \\
\text { Propodi }\end{array}$ & $.8742 \pm .0095$ & $.8685 \pm .0095$ & $.8888 \pm .0084$ & 1 \\
\hline Leg I.. & $.9539 \pm .0036$ & $.9677 \pm$ & $.8932 \pm .0081$ & $.8613 \pm .0104$ \\
\hline & $.9670 \pm .0026$ & $.9531 \pm .0037$ & $.9036 \pm .0074$ & $.8673 \pm .0099$ \\
\hline Leg III... & $.9736 \pm .0021$ & $.9463 \pm .0042$ & $.9027 \pm .0074$ & $.8757 \pm .0093$ \\
\hline Chabacter. & & $\begin{array}{l}\text { OPODITE OF } \\
\text { LEG I. }\end{array}$ & $\begin{array}{l}\text { Propodite of } \\
\text { LEG II. }\end{array}$ & $\begin{array}{l}\text { Propodite oF } \\
\text { LEG III. }\end{array}$ \\
\hline Cephalothor & & $349 \pm 0.005$ & \pm 0.0036 & $0.9525 \pm 0.0037$ \\
\hline Head & & $106 \pm .006$ & $.9209 \pm .006$ & $.9304 \pm .0054$ \\
\hline $\begin{array}{l}\text { Meri } \\
\text { Le }\end{array}$ & & & & \\
\hline Le & & $\begin{array}{l}3.0 \pm \\
40 \pm .00\end{array}$ & .95 & .95 \\
\hline Le & & $539 \pm .0036$ & $.9670 \pm .0026$ & $.9736 \pm .0021$ \\
\hline Carpop & & & & \\
\hline Leg I & & $677 \pm .0025$ & $.9 \overline{5} 31 \pm .0037$ & $.9463 \pm .0042$ \\
\hline & & $932 \pm .003$ & $.9036 \pm .0074$ & $.9027 \pm .0074$ \\
\hline Leg III.. & & $613 \pm .0104$ & $.8673 \pm .0099$ & $.8757 \pm .0093$ \\
\hline Prop & & & & \\
\hline $\begin{array}{l}\text { Le } \\
\text { Le }\end{array}$ & & $6+$ & $.9506 \pm .0039$ & $.9402 \pm$ \\
\hline Leg II & & $102 \pm .0016$ & $.9610 \pm .0031$ & 1 \\
\hline
\end{tabular}




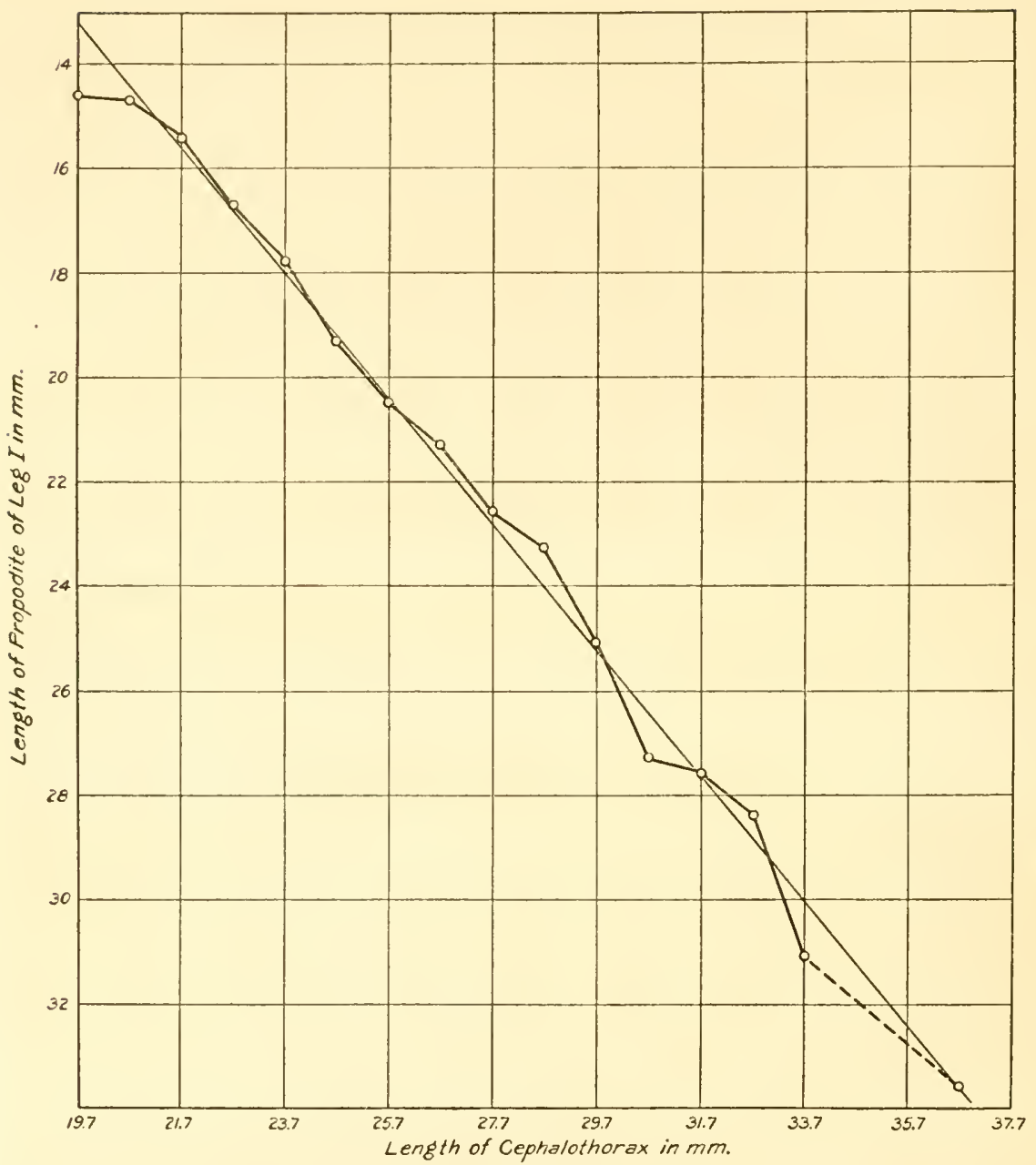

FIG. 5.-Diagram showing the regression of the propodite of leg I on the cephalothorax. The circles connected by a zigzag line give the means of the arrays of propodite length for given types of cephalothorax length. The straight line is the calculated line of regression.

The characteristic equations connecting the characters are as follows, where $P_{\mathrm{I}}$ denotes probable mean length in millimeters of the propodite of leg I for a given cephalothorax length $C$; and $M_{\text {III }}$ denotes probable mean length in millimeters of the meripodite of leg III for a given length, $M_{\mathrm{I}}$, of the meripodite of $\operatorname{leg} \mathrm{I}$ :

$$
\begin{aligned}
& P=1.2214 C-11.057 \ldots . \text { (I) } \\
& M_{\mathrm{HII}}=.7720 M_{1}+1.042 \ldots \text { (II) }
\end{aligned}
$$




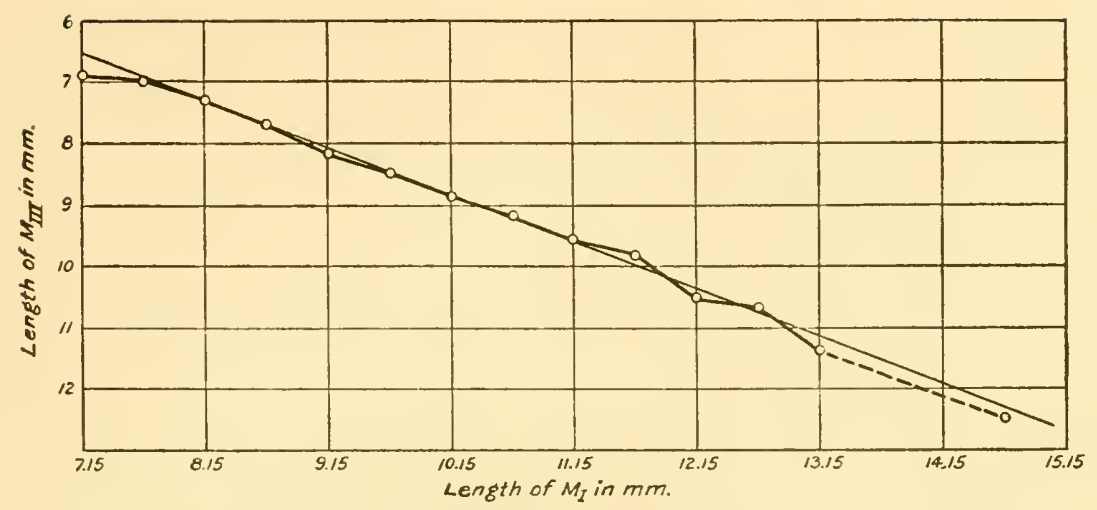

FrG. 6.-Diagram showing the regression of the meripodite of leg III on the meripodite of leg I. Significance of the lines as in fig. 5.

There can be no doubt as to the linearity of these regressions.

With these general data tables in hand we may proceed at once to the discussion of special topics.

\section{VARIATION AND DIFFERENTIATION.}

The question with which we have to do in this section is that of the relation of variation to differentiation and morphological specialization. In respect to all of the joints investigated, legs I, II, and III are differentiated from each other. In the case of leg $\mathrm{I}$ this differentiation is of course obvious. We have in the cheliped a part which has developed to a high degree in comparison with its serial homologues, the walking legs. This specialization in respect to size and form is associated with the performance of an altogether different set of functions from those of the walking legs. An examination of the following table shows at once that there is a sensible, if less marked, differentiation between corresponding joints of legs II and III.

TABLE 4.-Comparison of the mean length of corresponding joints in legs II and III.

[Means from table 1.]

\begin{tabular}{|c|c|c|c|}
\hline JoINTE. & LEG II. & LEG III. & Difference. \\
\hline Meripodite.... & $7.847 \pm 0.040$ & $8.819 \pm 0.042$ & $0.972 \pm 0.058$ \\
\hline Carpopodite............ & $4.800 \pm .026$ & $6.139 \pm .032$ & $1.339 \pm .041$ \\
\hline Propodite.................. & $7.060 \pm .034$ & $9.090 \pm .043$ & $2.030 \pm .055$ \\
\hline
\end{tabular}


Each joint of leg III is larger than the corresponding joint of leg II, by an amount which is in every case many times its probable error. Not only are legs II and III differentiated from one another in absolute size, but also in their proportions, as the following ratios show.

$$
\begin{aligned}
& \frac{100 \times \text { Carpopodite }}{\text { Meripodite }}, \operatorname{leg} I I=61.2 \text { per cent.; leg } I I I=69.6 \text { per cent. } \\
& \frac{100 \times \text { Carpopodite }}{\text { Propodite }}, \operatorname{leg} I I=68.0 \text { per cent.; leg } I I I=67.5 \text { per cent. } \\
& \frac{100 \times \text { Propodite }}{\text { Meripodite }}, \operatorname{leg} I I=90.0 \text { per cent.; leg } I I I=103.1 \text { per cent. }
\end{aligned}
$$

How do these differentiated appendages compare with respect to relative variability? Does the degree of variability run parallel to the degree of morphological specialization, or does the reverse relation hold? To show the bearing of our results on these questions, table 5 has been prepared. This gives the coefficient of variation for each joint of each leg. On account of the differentiation of the legs in absolute size it is idle to use the standard deviation as a measure of comparative variability.

\begin{tabular}{|c|c|c|c|}
\hline JOINT. & LEG I. & LEG II. & LEG III. \\
\hline Meripodite.. & $13.151 \pm 0.379$ & $12.821 \pm 0.369$ & $11.972 \pm 0.344$ \\
\hline Carpopodite & $14.267 \pm .413$ & $13.705 \pm .396$ & $13.184 \pm .380$ \\
\hline Propodite... & $18.047 \pm .528$ & $12.082 \pm .347$ & $11.789 \pm .339$ \\
\hline Mean. & 15.155 & 12.869 & 12.315 \\
\hline
\end{tabular}

TABLE 5.-Comparative variability of different appendages-coefficients of variation.

From this table we note the following points:

(a) Leg I is the most variable of the three; leg II stands next, and leg III is the least variable, but the differences between the last two are practically insignificant.

(b) The differences between corresponding joints of the different legs in respect to relative variability are, on the whole, small as compared with their probable errors. The only marked exception is the propodite in leg $\mathrm{I}$.

(c) The considerable excess of the mean variability of the joints of leg I over the means for legs II and III is largely due to the great variability of the propodite of leg I (i. e., the great chela). This is by far the most variable of any of the characters studied. The high variability of the great chela has been noted by other students of variation in the Crustacea (cf. Yerkes, 1901, and Schuster, 1903). 
From these results we conclude that the appendage which is most highly developed and specialized morphologically is also relatively the most variable. This may be taken as a confirmation of Darwin's law that highly developed parts tend to be more variable than corresponding parts of ordinary size. It is in agreement with Yerkes' (1901) results on Gelctsimus.

So far we have been considering the variability in proportion to the absolute size. Another equally important point to be considered is the variation, not in the absolute size of the parts, but in the proportions of the body. Thus it is conceivable that the great chela might be relatively the most variable part of the body in its absolute size, and yet that the proportionate length of this organ in relation, say, to the length of the cephalothorax would be one of the least variable dimensions. Having determined the relative variability of the parts in respect to absolute size, we must next study the variability in respect to proportions. This we may of course do by expressing each dimension in the form of an index. Thus, we may express the length of each joint of the legs as a percentage of the cephalothorax length, instead of in terms of millimeters or other absolute units. The variation of these indices will then measure the extent to which the proportions, as distinct from the size of the parts of the body are varying. In order to determine the variation shown by these indices we may resort to the theorem given by Pearson (1897). He has shown that if we let $i_{13}$ denote the mean value of an index, $x_{1} / x_{3} ; \Sigma_{13}$ the standard deviation of this index; and $v_{1}$ and $v_{3}$ the coefficients of variation of $x_{1}$ and $x_{3}$ and $r_{13}$ the coefficient of correlation between the same characters, then

$$
i_{13}=\frac{m_{1}}{m_{3}}\left(1+v_{3}{ }^{2}-r_{13} v_{1} v_{3}\right) \ldots \ldots \ldots \ldots \ldots \ldots \ldots \ldots \text { (I) }
$$

where $m_{1}$ and $m_{3}$ are the means of the characters $x_{1}$ and $x_{3}$, and

$$
\Sigma_{13}=i_{13} \sqrt{\left(v_{1}^{2}+v_{3}^{2}-2 r_{13} v_{1} v_{3}\right)} .
$$

In the present case it seems best to use the length of the cephalothorax as the basis of reference in determining the relative proportions of the different joints of the legs. That is, in the index fraction $x_{1} / x_{3}, x_{3}$ will denote in every case the length of the cephalothorax, while for $x_{1}$ will be put successively the different joints of the different legs. Proceeding in this way, and putting the result in each case in the form of a percentage, we shall have the length of each joint of the legs measured in hundredths of the cephalothorax length. 
Working in this way from formula (I) above, we have for the mean indices, or the mean proportions of the joints of the legs in comparison with cephalothorax length, the results set forth in table 6 .

\section{TABLE 6.-Mean proportions of the different joints of the legs.}

[Unit = 1 per cent. of cephalothorax length.]

\begin{tabular}{|c|c|c|c|}
\hline JoINT. & LEG I. & LEG II. & LEG III. \\
\hline 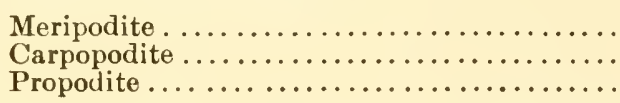 & $\begin{array}{l}38.63 \\
28.22 \\
79.15\end{array}$ & $\begin{array}{l}30.11 \\
18.44 \\
27.11\end{array}$ & $\begin{array}{l}33.86 \\
23.57 \\
34.91\end{array}$ \\
\hline
\end{tabular}

By this table of mean proportions the differentiation between the legs is again clearly shown. In passing it may be remarked that the values for the proportions of the different joints of the legs as given in this table will perhaps be useful for diagnostic purposes in defining the species, since they represent the mean of a considerable number of specimens. In this connection, however, the point brought out in a later section of the paper, dealing with "index correlations" (pp. 40-45), must be kept in mind.

Turning to the question of the relative variability in the proportions of the different legs, we have the results given in table 7 . The values in this table are the standard deviations of the indices whose means are given in table 6 .

TABLE 7.-Variability of the proportions of the different joints of the legs.

[Unit $=1$ per cent. of cephalothorax length.]

\begin{tabular}{|c|c|c|c|}
\hline \multirow{2}{*}{ JOINT. } & \multicolumn{3}{|c|}{ Standard DEviation. } \\
\hline & Leg I. & Leg II. & Leg III. \\
\hline Meripodite.. & $1.516 \pm 0.043$ & $1.433 \pm 0.041$ & $1.170 \pm 0.033$ \\
\hline Carpopodite & $1.461 \pm .041$ & $1.150 \pm .033$ & $1.593 \pm .045$ \\
\hline Propodite .... . & $6.875 \pm .195$ & $0.997 \pm .028$ & $1.255 \pm .036$ \\
\hline Mean. & 3.284 & 1.193 & 1.339 \\
\hline
\end{tabular}

From this table the following points are to be noted:

(a) Leg I, the most highly developed and differentiated of the three under consideration, is the most variable in its proportionate as well as in its absolute size. 
(b) When the proportionate size is considered, the order of comparative variability of the legs is I, III, and II, whereas when we deal with absolute size the order is I, II, and III, as shown in table 5 above. The difference between legs II and III in mean variability is relatively greater for the proportionate than for the absolute dimensions.

(c) The great excess in variability indicated by the mean of the "leg I" column of the table is, as before, clearly due in large measure to the extreme variability of a single joint, the great chela. However we measure this joint it is far and away the most variable of the lot.

(d) The extremely low variability of all the appendage-cephalothorax indices (with the exception of that involving the propodite of leg I) is noteworthy. It is another expression of the fact of extremely high correlation in the parts of the crayfish body, which we have already seen. Schuster (loc. cit.) found a very low variability of the chela index in Eupagurus.

Putting all our results together, we have seen that when we compare the several joints of three differentiated but serially homologous appendages of the crayfish in respect to relative variability, it is found that the leg bearing the great chela is, in all the joints studied, the most variable. This is true whether we deal with the variation of the parts in their absolute sizes or with the variations in their proportionate dimensions referred to the cephalothorax length as a base. But it is obvious that the leg bearing the great chela is the one of those studied which is most widely differentiated from the primitive type of the decapod limb, and is also most highly specialized for the performance of a particular set of functions. We hence conclude that, in the present case at least, a relatively high degree of morphological differentiation and specialization has associated with it a relatively high degree of variability in the parts concerned. This, so far, is merely a statement of a fact regarding the external morphology of the crayfish, and involves no theory as to the nature or cause of such a relationship. An obvious suggestion as to the cause of the greater variation shown by leg I is that since this is the appendage which is on the whole most liable to injury, it will most often be in process of regeneration. It might perhaps be maintained that our sample contained a considerable number of individuals regenerating in this leg, and that the greater variation really arose because of the inclusion of different regeneration stages. It is possible that a part of the observed result is to be explained in this way, but in our opinion the influence of the possible inclusion of regenerating individuals must be 
altogether insignificant in bringing about our observed results. There are several reasons for this opinion. In the first place, as has been stated above (p. 3), before the measuring was begun the material was very carefully examined and in every case where there was the slightest evidence that regeneration in any of the appendages measured was going on, the specimen was put aside and not included in the measuring. This would at once exclude all but those in which regeneration was very nearly complete, and that there should have been any considerable portion of the sample in which the right chela was in such an advanced stage of regeneration as to be indistinguishable from the normal under careful examination, is very unlikely. Furthermore the facts that (I) each of the three joints studied is more variable in leg $I$ than in either of the two other legs, and (II) that the propodite of leg I is much more variable than either the meripodite or carpopodite of that leg when taken together, seem to us very difficult if not impossible of explanation on the assumption that the observed degree of variation in leg I is in any considerable part the result of the inclusion of non-homogeneous regenerating material.

The matter may be looked at in another way. It might be assumed, with a fair degree of probability, that in any random sample whatever of adult crayfish taken from their natural habitat there would be a definite, perhaps even considerable, proportion of individuals which had regenerated at some previous time one or both of the great chelæ. If, then, it be further assumed that there is a tendency for a regenerated structure to be formed with less quantitative precision - that is, in the aggregate with greater variation - than when it is originally formed in the normal ontogeny, we have at once an explanation for the greater observed variation of leg I as compared with legs II and III. The chief difficulty with this hypothesis is that we are in absolute ignorance as to the validity of the second assumption. No systematic biometrical study of the relative variability of original and regenerated structures has ever been made, though the field to be opened up by such work is a most promising one. It leads at once to the general problem of the relative precision with which different morphogenetic processes operate. I have discussed this problem in some detail for the normal ontogeny* and have been able to demonstrate for one form, at least, that parts successively produced tend to become less variable with each successive formation. If the same law should hold true for regenerated structures as for successive formations

*Cf. Pearl, Pepper, and Hagle, 1907. 
in the normal ontogeny, then clearly the second assumption made at the beginning of this paragraph is incorrect, and the suggested explanation of our present results would fail. It is impossible to reach any conclusion regarding the point until biometrical studies on regeneration have been made.

One further point in this connection is of interest. There is no reasonable doubt that the differentiated, specialized condition of the leg bearing the great chela is phylogenetically a relatively late acquisition. In other words, it is not a primitive morphological condition. But we find that this part which has been modified most recently phylogenetically is also the most variable of the three appendages studied. In so far we have direct statistical confirmation in a single case of the dictum that phylogenetically young structures tend to be more variable than those older and more primitive. In our opinion, however, no particular stress is to be laid on this fact. The real cause of the greater variability of the cheliped appears to us to lie most probably in ontogenetic (in particular, growth) rather than phylogenetic factors.

So far we have discussed the variation in the appendage as a whole. We may now consider very briefly the different segments of the leg separately with reference to their comparative variability. The data are given in convenient form in tables 5 and 7 . It has already been noted that the most variable single joint of all those on which we have data is the propodite of leg I. Leaving this out of account as a specialized organ, and comparing the other segments, it is seen from table 5 that in both legs II and III the carpopodite is relatively the most variable. Also in the case of leg I the carpopodite is more variable than the meripodite. A relatively high degree of variability of the carpopodite, as compared with meripodite and propodite, is shown in Yerkes' (1901) figures for Gelasimus pugilator. Our results thus stand in agreement with his on this point. In legs II and III the meripodite and propodite are substantially equally variable. The differences in the coefficients are almost certainly insignificant in comparison with their probable errors. These are the results when the variation is measured from the absolute dimensions. If we consider the variation in the proportions of the different segments as given in table 7 the results are not quite so regular. Leaving out the great chela as before, we see that in legs II and III the meripodite is more variable than the carpopodite. The difference is probably not significant in the case of leg I, but it certainly is in leg II. In leg III the carpopodite is again the most variable joint. It might be thought that the 
terminal segment of a series such as that presented by the leg of the crayfish would occupy an extreme position with respect to relative variability, but such does not appear to be the case. The propodite is neither the most variable nor the least variable joint uniformly.

We may next examine somewhat more in detail the facts regarding the skewness in the different segments of the appendages. In table 8 the data are arranged in convenient form for comparison.

TABLE 8.-Skewness in variation of the different joints.

\begin{tabular}{|c|c|c|c|}
\hline \multirow{2}{*}{ Segment of Leg. } & \multicolumn{3}{|c|}{ SkEWNess (+ IN ALL Cases). } \\
\hline & Leg I. & Leg II. & Leg III. \\
\hline 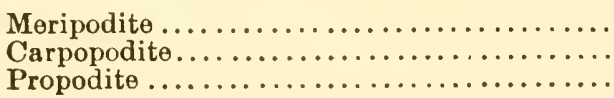 & $\begin{array}{r}0.3077 \\
.3144 \\
.4139\end{array}$ & $\begin{array}{r}0.3530 \\
.3619 \\
.2406\end{array}$ & $\begin{array}{r}0.3158 \\
.3293 \\
.0994\end{array}$ \\
\hline 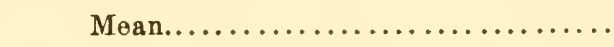 & .3453 & .3185 & .2482 \\
\hline
\end{tabular}

We see from this table that-

(a) Considering the means of the columns, leg I shows the greatest skewness in its variation, and there is a steady decrease as we pass to legs II and III. Great weight, however, is not to be laid on this conclusion drawn from the means, for the reason that it is obvious that the excess of the mean skewness for leg I over that for leg II is due entirely to the influence of a single joint, the propodite of leg $\mathrm{I}$. It was shown above that the great chela was the most variable single segment, and it is now seen that it also has the greatest skewness in its distribution. In other words, the most specialized structure of those studied shows a maximum degree not only of variability but also of skewness.

(b) Leaving the great chela out of account, the segment which in each leg gives the distribution with the greatest skewness is the carpopodite. The difference between carpopodites and meripodites in skewness is not large, but since in every case it is in the same direction, it is probably safe to conclude that there is a slight tendency for the former to have generally the more asymmetrical distributions. Here, as in $(a)$, we find degree of skewness and degree of variability going parallel, it having been shown above (p. 16) that the carpopodite is the most variable of the joints after the great chela is put aside.

(c) The low degree of skewness in the distributions for the propodites of legs II and III is noteworthy. In fact, the propodite distribution for leg III is, within the limits of error from random sampling, symmetrical. 
Summarizing the results of the section: It has been shown that in the system of organs given by the joints of the crayfish leg, the most highly differentiated and specialized organ of those studied, the great chela, exhibits the greatest amount of variation and the highest degree of skewness in its variation. Aside from the great chela the most variable single segment on each leg is the carpopodite. This joint also shows the greatest skewness in its distributions. In the cases where the differentiation between segments is not very great in amount, there is very little difference in the relative variabilities. So far as our variation results go they suggest the following conclusions:

(I) That relative degree of morphological development or specialization and relative degree of variability run parallel.

(II) That degree of skewness and degree of variation tend to run parallel.

It is to be understood that these are only the statements of results obtained from the present material. They are not offered as generalizations, but rather as suggestions of questions on which any additional data will be welcome.

\section{CORRELATION AND LOCATION OF PARTS.}

The discussion of the correlation results may conveniently be begun with the consideration of the problem of the influence of the relative position of two organs on the correlation between them. Is the correlation between two contiguous organs or parts in general greater than the correlation between two organs more or less widely separated from one another? Or, put more generally, is there any definite relation between degree of correlation and relative location of parts within the organism? It is obvious that a definite answer to this question would be of importance in any attempt to formulate a general theory of the origin and laws of organic correlation. In their elaborate study of the correlation between the different bones of the human hand Lewenz and Whiteley (1902) found in several instances clear evidence of such a "rule of neighbourhood," as they term it. Thus they find (p. 360) that:

Generally there is a "rule of neighbourhood," $\mathrm{i}$. e., any bone is more closely correlated with a second of the same series than with any other from which it is separated by that second. Speaking roundly this is true for both lateral and longitudinal series; but there are apparently significant deviations from this rule, the most notable of which are, perhaps, those of the distal phalanges, which on all of the fingers of both hands tend to be more highly correlated with the metacarpal bones or the proximal phalanges than with the middle phalanges. 'The middle phalanges, however, obey the general rule. 
In his study of correlation in Gelasimus pugilator Duncker (1903) finds evidence of a law of contiguity. He says (p. 319):

Der wie bei bilateral homologen Merkmalen überhaupt stets positive Korrelationskoeffizient der untersuchten Paare homologer Dimensionen ist um so grôsser, je nahher die gemessenen Organe einander liegen.

With our present material it is obvious that we may consider the question of contiguity and correlation from two standpoints. First, we may take the structures in contiguous or non-contiguous metameres, i. e., in the antero-posterior series; and again, we may test the matter on the contiguous and non-contignous segments within the single metamere. This last gives what may be called a lateral series.

Taking first the location of parts in successive metameres, table 9 has been arranged to bring together the results in most convenient form for direct comparison. Since we have data from three legs, it is evident that there are three possible combinations of pairs, viz, I with II, I with III, and II with III. In the second, third, and fourth vertical columns of the table the correlation coefficients for the joints of these three combinations of legs are given. The particular pair of joints to which an individual coefficient belongs is given in the first column of the table. The first joint of each pair as they are entered in this column always belongs to the first leg of each of the three pairs at the heads of the columns. Thus, to take a single example to illustrate how the table is to be read, by looking at the point where the sixth row and the second column of figures meet, the entry 0.9601 is seen; this is the coefficient measuring the correlation between the carpopodite of the cheliped and the meripodite of the second walking leg. Finally, in the last column of the table a plus sign $(+)$ is entered whenever the correlation between a contiguous pair of legs is greater than the correlation between a non-contiguous pair. When the correlation is greater for a non-contiguous pair a minus sign $(-)$ is entered.

TABLE 9.-Correlation and location of segments.

\begin{tabular}{|c|c|c|c|c|}
\hline Segments. & LEGS I AND II. & LEGS I AND III. & LEGS II AND III. & Excess. \\
\hline Meripodite with meripodite.. & $0.9665 \pm 0.0026$ & $0.9686 \pm 0.0025$ & $0.9729 \pm 0.0021$ & -+ \\
\hline Carpopodite with carpopodite. & $.9069 \pm .0071$ & $.8685 \pm .0099$ & $.8888 \pm .0084$ & \\
\hline Propodite with propodite..... & $.9506 \pm .0039$ & $.9402 \pm .0046$ & $.9601 \pm .0031$ & ++ \\
\hline Meripodite with carpopodite.. & $.8943 \pm .0080$ & $.8652 \pm .0101$ & $.8632 \pm .0102$ & +- \\
\hline Meripodite with propodite.... & $.9578 \pm .0033$ & $.9579 \pm .0033$ & $.9559 \pm .0035$ & - - \\
\hline Carpopodite with meripodite.. & $.9502 \pm .0039$ & $.9601 \pm .0031$ & $.9021 \pm .0075$ & $=-$ \\
\hline Carpopodite with propodite... & $.9531 \pm .0037$ & $.9463 \pm .0042$ & $.9027 \pm .0074$ & +- \\
\hline Propodite with meripodite. & $.9440 \pm .0044$ & $.9539 \pm .0036$ & $.9670 \pm .0026$ & -+ \\
\hline Propodite with carpopodite... & $.8932 \pm .0081$ & $.8613 \pm .0104$ & $.8673 \pm .0099$ & $+t$ \\
\hline
\end{tabular}


From this table it is seen at once that the results with homologous joints are quite different from those with non-homologous. Considering only the pairs of homologous joints at the upper end of the table, there is only one case out of the possible six in which the correlation is higher between the non-contiguous pair of legs. In that case the difference between the two coefficients is altogether insignificant in comparison with its probable error (difference $=0.0021 \pm 0.0036$ ). The "rule of neighbourhood" thus evidently holds for the correlation between homologous joints of the different legs. The result may be stated in the following way: The correlation between the homologous segments of two legs is higher when these two legs belong to contiguous metameres than when they are separated by an intervening metamere.

There are twelve chances of comparison when the correlations of the non-homologous segments are considered. A reference to the last column of the table shows that in six of these cases the correlation is higher in the non-contiguous pair of legs; while in five cases it is ligher in the contiguous pairs. In one case there is practically exact equality between the coefficients, the difference being only 0.0001 . The indication clearly is that, so far as the non-homologous joint correlations are concerned, it is about an even chance whether the excess will be in favor of the contiguous or the non-contiguous pairs of legs. Before definitely accepting this conclusion, however, it will be well to determine whether the plus $(+)$ differences are in the aggregate larger than the minus (-), or vice versa. Further, it is clear that it will be better to compare the proportions of the differences to their probable errors rather than to the absolute values. Accordingly, in table 10 is given for each plus $(+)$ and minus $(-)$ difference in the lower half of table 9 , the value of the ratio of the difference to its probable error (i. e., Diff. /P. E. Diff.).

$\mathrm{T}_{\mathrm{ABLE}}$ 10.-Correlation differences, to show the relative significance of the plus (+) and minus (-) entries in the last column of table 9.

\begin{tabular}{|c|c|}
\hline \multicolumn{2}{|c|}{ Diff. / P.E. Diff. } \\
\hline Plus (†). & Minus (-). \\
\hline 2.26 & 0.14 \\
1.21 & .42 \\
2.98 & 1.98 \\
2.42 & 7.16 \\
0.42 & 5.13 \\
$\cdots$. & 1.74 \\
\hline 11.86 & 12.76 \\
\hline
\end{tabular}

1 Mean, 
From this table it is quite clear that neither the plus $(+)$ nor the minus (-) set of differences can be discarded as probably merely a result of random sampling. Instead it must be concluded that there are real and definite exceptions to the rule of contiguity when the correlations of nouhomologous joints are considered. The most striking exceptions to the rule are the correlations which involve as one variable the carpopodite of leg I. Three out of the four of these correlations give minus ( - ) excesses and two are very large, the differences ratios being 7.16 and 5.13, the largest in the table. On the whole we may conclude that in the correlation of non-homologous segments of legs belonging to different metameres there is no definite evidence in favor of the rule of contiguity. The most striking exceptions to the rule are the correlations involving the carpopodite of the cheliped.

We may next consider the problem of the influence of position on correlation within the metamere. The question here is: Are contiguous segments of the same leg more highly correlated than non-contiguous segments? To answer this table 11 has been prepared on the same general plan as table 9. As before, the excess is designated plus $(+)$ when the contiguous joint correlations are the larger.

TABLE 11.-Correlation and position within the same metamere.

\begin{tabular}{|c|c|c|c|c|}
\hline LEG. & $\begin{array}{l}\text { MERIPODITE WITH } \\
\text { CARPOPODITE. }\end{array}$ & $\begin{array}{l}\text { MERIPODITE WITh } \\
\text { Propodite. }\end{array}$ & $\begin{array}{c}\text { CARPOPODITE } \\
\text { WITH PEOPODITE. }\end{array}$ & ExcEss. \\
\hline $\begin{array}{r}\text { I } \ldots . \\
\text { II } \ldots \\
\text { III } \ldots\end{array}$ & $\begin{array}{rrr}0.9588 & \pm & 0.0032 \\
.9083 & \pm .0070 \\
.8742 & \pm & .0095\end{array}$ & 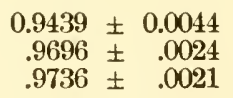 & $\begin{array}{c}0.9677 \pm 0.0025 \\
.9036 \pm .0074 \\
.8757 \pm .0093\end{array}$ & 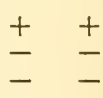 \\
\hline
\end{tabular}

It is evident that we have here the exact opposite of the rule of contiguity, except in the case of leg I. There the two correlations involving the carpopodite are high, just as they were found to be in the crosscorrelations considered above. In legs II and III the non-contiguous joint correlations are greatly in excess of the contiguous. Too much stress can not be laid on this result, however, because of the fact that we are dealing with only three joints. Both of the contiguous joint correlations necessarily involve the carpopodite as one of the variables. Now, a study of table 3 will show that generally the carpopodite correlations of legs II and III are low, irrespective of the relative positions of the joints correlated. On the other hand the carpopodite correlations of leg I are relatively high. There is apparently some other special factor influencing 
carpopodite correlations which is strong enough to outweigh any potential influence of position. The question as to whether the rule of contiguity holds within the metamere can not be definitely settled until a larger number of segments than is here considered has been dealt with from each leg.

The results set forth in this section of the paper may be summarized as follows: The rule that structures occupying positions within the organism contiguous to one another are more highly correlated together than non-contiguous structures is found to hold (with a single insignificant exception) for the correlations of the homologous segments of different legs; it also holds for about half of the correlations between the non-homologous joints of different legs; it fails signally in those correlations involving a carpopodite as one of the variables, both in the case of the non-homologous joint correlations of the different legs and in the case of the correlations of the joints of the same leg. These exceptions are probably due to the influence of some special factor concerned in the carpopodite correlations.

\section{CORRELATION AND HOMOLOGY.*}

The problems to be considered in this section are as to the influence of morphological homology on the degree of correlation between parts. Are homologous structures in general more highly correlated than functionally similar but non-homologous structures? Our data furnish abundant material from which light may be gained on this and the subsidiary questions which are suggested by it. We may first attack the general problem according to the following plans: It is evident that the same segments of the different legs are serially homologous. The correlations between these will furnish data for the "homologous"

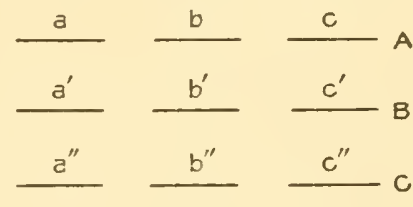

FIG. 7.-For explanation see text. side of the comparison. What shall be compared with these to make a fair test? It is clear that there are several possible ways to proceed. The correlation between joint $a$ of leg A (fig. 7) and its homologue, joint $a$ of $\operatorname{leg} \mathrm{B}$, may be compared with the correlations (I) between joint $a^{\prime}$ of leg A and joint $b^{\prime}$ of $\operatorname{leg} \mathrm{B}$; (II) between joint $a$ of $\operatorname{leg} \mathrm{A}$ and joint $c^{\prime}$ of leg $\mathrm{B}$.

* A preliminary paper dealing with the subject taken up in this section has been published by Clawson (1905). An entire recalculation of the constants after the publication of this preliminary paper led to the discovery of several minor arithmetical errors. These have now been corrected with the effect of making the whole system of correlations somewhat smoother, but without essentially affecting the conclusions. 
Similar combinations may be made for joint $a^{\prime}$ of leg B and joint $a^{n}$ of leg c. The whole system so formed will afford a comparison between (a) the correlation of a joint in a first leg with its homologue in a second leg, and $(\beta)$ the correlation of the first joint with the non-homologous joints of the second leg. It is clear that in such a system of comparison we avoid entirely any possible conflicting influence of the two factors homology and contiguity of parts within the metamere. In order to detect what the relative influence may be of homology and contiguity in an antero-posterior direction (i. e., between metameres), we have merely to separate the data in the appropriate way in the tables. In all of these tables a plus $(+)$ entry in the column headed "excess" means that the constants for a pair of homologous joints is greater than that for the corresponding nou-homologous pair. The data are given in table 12.

TABLe 12.

(A) MERIPODITES OF LEGS I AND II, AND II AND III (CONTIGUOUS METAMERES).

\begin{tabular}{|c|c|c|c|c|c|}
\hline 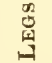 & $\begin{array}{l}\text { HOMOLOGOUS } \\
\text { JoINTS. }\end{array}$ & CoEfficient. & Excess. & Coefficient. & Non-номоLOgOUs JoINTs. \\
\hline 四 & $\begin{array}{c}\text { Meripodite II } \\
\text { with meripo- } \\
\text { dite III } \\
\left.a^{\prime \prime}\right) .\end{array}$ & $0.9665 \pm 0.0026$ & $\begin{array}{l}+(8.60) \\
+(2.07) \\
+(3.51) \\
+(4.41) \\
+(10.55) \\
+(4.25) \\
+(9.19) \\
+(1.79)\end{array}$ & $\begin{array}{l}0.8943 \pm 0.0080 \\
.9578 \pm .0033 \\
.0502 \pm .0039 \\
.9440 \pm .0044 \\
.8632 \pm .0102 \\
.9559 \pm .0035 \\
.9021 \pm .0075 \\
.9670 \pm .0026\end{array}$ & $\begin{array}{l}\text { Meripodite I with car- } \\
\text { popodite II }\left(a b^{\prime}\right) \text {. } \\
\text { Meripodite I with pro- } \\
\text { podite II }\left(a c^{\prime}\right) \text {. } \\
\text { Meripodite II with car- } \\
\text { popodite I }\left(a^{\prime} b\right) \text {. } \\
\text { Meripodite II with pro- } \\
\text { podite I }\left(a^{\prime} c\right) \text {. } \\
\text { Meripodite II with car- } \\
\text { popodite III }\left(a^{\prime} b^{\prime \prime}\right) \text {. } \\
\text { Meripodite II with pro- } \\
\text { podite III }\left(a^{\prime} c^{\prime \prime}\right) \text {. } \\
\text { Meripodite III with } \\
\text { carpopodite II }\left(a^{\prime \prime} b^{\prime}\right) \text {. } \\
\text { Meripodite II with pro- } \\
\text { podite I }\left(a^{\prime \prime} c^{\prime}\right) \text {. }\end{array}$ \\
\hline
\end{tabular}

(B) MERIPODITES F LEGS I AND III (NON-CONTIGUOUS METAMERES).

\begin{tabular}{|c|c|c|c|c|c|}
\hline $\begin{array}{l}\Xi \\
\Xi \\
\Xi \\
\Xi \\
\varpi\end{array}$ & $\left.\begin{array}{c}\text { Meripodite I } \\
\text { with meripo- } \\
\text { dite In }\left(a a^{\prime \prime}\right) .\end{array}\right\}$ & $0.9686 \pm 0.0025$ & $\begin{array}{l}+(9.94) \\
+(2.61) \\
+(2.18) \\
+(3.42)\end{array}$ & $\begin{array}{r}0.8652 \pm 0.0101 \\
.9579 \pm .0033 \\
.9601 \pm .0031 \\
.9539 \pm .0036\end{array}$ & $\begin{array}{l}\text { Meripodite I with car- } \\
\text { popodite II }\left(a b^{\prime \prime}\right) \text {. } \\
\text { Meripodite I with pro- } \\
\text { podite III }\left(a c^{\prime \prime}\right) \text {. } \\
\text { Meripodite III with } \\
\text { carpopodite I }\left(\alpha^{\prime \prime} b\right) \text {. } \\
\text { Meripodite III with } \\
\text { propodite I }\left(a^{\prime \prime} c\right) \text {. }\end{array}$ \\
\hline
\end{tabular}

1 The letters in parentheses in this and succeeding tables refer to fig. 7. 
The results shown in table 12 are very regular. In every case the correlation is greater between the homologous joints than it is between the non-homologous, though some of the differences are absolutely small. The figures in the "excess" column show the relative significance of these differences in comparison with their probable errors. These figures are the values of the ratio Difference/Probable error of difference. Taking into consideration the values of this ratio in the different cases and also the fact that in every case the difference is in the same direction, it is clearly justifiable to conclude that there is a uniform and definite tendency for the meripodite of any leg to be more highly correlated with the homologous segment (i. e., the meripodite of a second leg) than with any other segment of that second leg. It is, of course, to be understood that this statement is made only for those legs and joints studied in this work.

We may turn next to the carpopodite correlations (table 13), treating the data in the same way.

TABLE 13.

(A) CARPOPODITES OF LEG I AND II, AND II AND III (CONTIGUOUS METAMERES).

\begin{tabular}{|c|c|c|c|c|c|}
\hline $\begin{array}{l}\text { 离 } \\
\text { 桼 }\end{array}$ & $\begin{array}{l}\text { HomoLoGơs } \\
\text { JoINTs. }\end{array}$ & Coefficient. & Excess. & Coefficient. & Non-HoMoLOGOUs JoINTs. \\
\hline 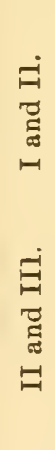 & $\begin{array}{l}\text { Carpopodite I } \\
\text { with carpo- } \\
\text { podite II } \\
\left(b b^{\prime \prime}\right) \text {. }\end{array}$ & $0.9069 \pm 0.0071$ & $\begin{array}{l}-(5.35) \\
-(5.78) \\
+(1.18) \\
+(1.28) \\
-(1.19) \\
-(1.24) \\
+(1.94) \\
+(1.67)\end{array}$ & $\begin{array}{r}0.9502 \pm 0.0039 \\
.9531 \pm .0037 \\
.8943 \pm .0080 \\
.8932 \pm .0081 \\
.9021 \pm .0075 \\
.9027 \pm .0074 \\
.8632 \pm .0102 \\
.8673 \pm .0099\end{array}$ & $\begin{array}{c}\text { Carpopodite I with } \\
\text { meripodite II }\left(b a^{\prime}\right) \text {. } \\
\text { Carpopodite I with } \\
\text { propodite II }\left(b c^{\prime}\right) \text {. } \\
\text { Carpopodite II with } \\
\text { meripodite I }\left(b^{\prime} a\right) \text {. } \\
\text { Carpopodite II with } \\
\text { propodite I }\left(b^{\prime} c\right) \text {. } \\
\text { Carpopodite II with } \\
\text { meripodite II }\left(b^{\prime} a^{\prime \prime}\right) \text {. } \\
\text { Carpopodite II with } \\
\text { propodite III }\left(b^{\prime} c^{\prime \prime}\right) \text {. } \\
\text { Carpopodite II with } \\
\text { meripodite II }\left(b^{\prime \prime} a^{\prime}\right) \text {. } \\
\text { Carpopodite III with } \\
\text { propodite II }\left(b^{\prime \prime} c^{\prime}\right) \text {. }\end{array}$ \\
\hline$\underset{\Xi}{\Xi}$ & $\begin{array}{c}\text { Carpopodite I } \\
\text { with carpo- } \\
\text { podite III } \\
\left(b b^{\prime \prime}\right) .\end{array}$ & $0.8685 \pm 0.0099$ & $\begin{array}{l}-(8.89) \\
-(7.27) \\
+(0.23) \\
+(0.50)\end{array}$ & $\begin{array}{r}0.9601 \pm 0.0031 \\
.9463 \pm .0012 \\
.8652 \pm .0101 \\
.8613 \pm .0104\end{array}$ & $\begin{array}{l}\text { Carpopodite I with } \\
\text { meripodite III }\left(b a^{\prime \prime}\right) \text {. } \\
\text { Carpopodite I with } \\
\text { propodite III }\left(b c^{\prime \prime}\right) \text {. } \\
\text { Carpopodite III with } \\
\text { meripodite I }\left(b^{\prime \prime} a\right) \text {. } \\
\text { Carpopodite III with } \\
\text { propodite I }\left(b^{\prime \prime} c\right) \text {. }\end{array}$ \\
\hline
\end{tabular}


Table 13 shows perfect regularity in the trend of the "excess," but it is of a quite different kind from that observed in table 12. Here there is no uniform rule that the homologous joints show the higher correlations. Instead there appears to be a special factor governing the carpopodite correlations which leads to a rule which may be formulated in the following way: (I) The carpopodite of any given leg is correlated to a relatively high degree with the meripodite and propodite of each of the legs which lie posterior to it, and further, the correlations of carpopodite with meripodite and propodite are practically equal; (II) the carpopodite of any given leg is correlated to a relatively low degree with the meripodite and propodite of each of the legs anterior to it, and again these correlations are substantially equal. Consequently we find that the "homologous joint" carpopodite correlations are higher than the nonhomologous joint correlations when the latter are directed anteriorly (by II), and lower when they are directed posteriorly (by I). Consequently, as a result of special factors influencing carpopodite correlations, the effect of homology is in part overshadowed. It is clear from the figures in parentheses in the excess column that the minus (-) differences are relatively, as well as absolutely, greater than the plus $(+)$.

The clata for the propodite correlations are given in table 14 .

The results here are rather more irregular than one could wish. There is clearly no uniform tendency for the homologous joint correlations to be higher than the non-homologous. In both the contiguous metamere and non-contiguous metamere groups there is a mixture of plus $(+)$ and minus (-) entries in the excess column. Consequently, in order to get a notion of the general trend of the results, we are thrown back on an estimate of the relative magnitude of the plus and minus differences. From the figures in the excess column it is evident that on the whole the plus differences run distinctly larger than the minus. The average of all the plus difference ratios is 5.32, while for the minus ratios it is 1.62. From this it appears reasonable to conclude that on the whole there is a distinct, though very slight, tendency for the correlations of homologous propodite segments to be higher than those of non-homologous joint pairs involving a propodite as one variable.

Putting all the results set forth in tables 12 to 14 together, we may conclude that in general, so far as indicated by our present material, there is a slight but distinct tendency for homologous pairs of joints to be more closely correlated than non-homologous pairs. In the case of 
pairs involving a carpopodite as one variable this tendency is outweighed by special positional influences affecting the variations and correlations of this joint. In general the influence of homology on correlation is a comparatively weak one-not nearly so strong as would probably have been predicted.

TABLE 14.

(A) PROPODITES OF LEGS I AND II, AND II AND III (CONTIGUOUS METAMERES).

\begin{tabular}{|c|c|c|c|c|c|}
\hline $\begin{array}{l}\dot{D} \\
\text { D } \\
\text { 思 }\end{array}$ & $\begin{array}{l}\text { HOMOLOGOU⿴ } \\
\text { JoINTS. }\end{array}$ & COEFFicient. & EXCESS. & Coefficient. & NON-HOMOLOGOUg JoINTs. \\
\hline 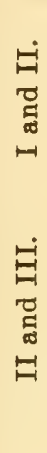 & $\left.\begin{array}{c}\text { Propodite I } \\
\text { with propo- } \\
\text { dite II }\left(c c^{\prime}\right) .\end{array}\right\}$ & $0.9506 \pm 0.0039$ & $\begin{array}{l}+(1.14) \\
+(6.45) \\
-(1.41) \\
-(0.47) \\
-(1.50) \\
+(9.01) \\
+(1.11) \\
+(7.29)\end{array}$ & $\begin{array}{l}0.9440 \pm 0.0044 \\
.8932 \pm .0081 \\
.9578 \pm .0033 \\
.9531 \pm .0037 \\
.9670 \pm .0026 \\
.8673 \pm .0099 \\
.9559 \pm .0035 \\
.9027 \pm .0074\end{array}$ & $\begin{array}{l}\text { Propodite I with meri- } \\
\text { podite II }\left(c a^{\prime}\right) \text {. } \\
\text { Propodite I with car- } \\
\text { popodite II }\left(c b^{\prime}\right) \text {. } \\
\text { Propodite II with meri- } \\
\text { podite I }\left(c^{\prime} a\right) \text {. } \\
\text { Propodite II with car- } \\
\text { popodite I }\left(c^{\prime} b\right) \text {. } \\
\text { Propodite II with meri- } \\
\text { podite III }\left(c^{\prime} a^{\prime \prime}\right) \text {. } \\
\text { Propodite II with car- } \\
\text { popodite II }\left(c^{\prime} b^{\prime \prime}\right) \text {. } \\
\text { Propodite III with meri- } \\
\text { podite II }\left(c^{\prime \prime} a^{\prime}\right) \text {. } \\
\text { Propodite III with car- } \\
\text { popodite II }\left(c^{\prime \prime} b^{\prime}\right) \text {. }\end{array}$ \\
\hline
\end{tabular}

(B) PROPODITES OF LEGS I AND III (NON-CONTIGUOUS METAMERES).

\begin{tabular}{|c|c|c|c|c|c|}
\hline 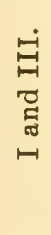 & $\left.\begin{array}{c}\text { Propodite I } \\
\text { with propo- } \\
\text { dite III }\left(c c^{\prime \prime}\right) .\end{array}\right\}$ & $0.9402 \pm 0.0046$ & $\begin{array}{l}-(2.36) \\
+(6.92) \\
-(3.16) \\
-(0.98)\end{array}$ & $\begin{array}{r}0.9539 \pm 0.0086 \\
.8613 \pm .0104 \\
.9579 \pm .0033 \\
.9463 \pm .0042\end{array}$ & $\begin{array}{l}\text { Propodite I with meri- } \\
\text { podite III }\left(c a^{\prime \prime}\right) \text {. } \\
\text { Propodite I with car- } \\
\text { popodite III }\left(c b^{\prime \prime}\right) \text {. } \\
\text { Propodite III with meri- } \\
\text { podite I }\left(c^{\prime \prime} a\right) \text {. } \\
\text { Propodite II with car- } \\
\text { popodite I }\left(c^{\prime \prime} b\right) \text {. }\end{array}$ \\
\hline
\end{tabular}

The next problem to be considered with reference to the influence of homology on correlation is as to the relative effect of homology and of contiguity within the metamere on the degree of correlation. Is a given segment in general more or less highly correlated with the homologous segment in another leg than it is with the other segments (contiguous and non-contiguous) of the leg to which it belongs itself? The data on this question are presented in tables 15 to 17 , which are arranged on the same plan as tables 12 to 14 . 
From table 1.5 it would appear that, so far as meripodite correlations are concerned, there is a distinct tendency for homologous joints of two different legs to be more highly correlated together than are the different joints of the same leg, whether contiguous or not. There are only three exceptions to the rule, and in these cases the differences are insignificant in comparison with their probable errors (cf. excess column).

TABLE 15.

(A) MERIPODITES OF LEGS I AND II, AND II AND III (CONTIGUOUS METAMERES).

\begin{tabular}{|c|c|c|c|c|c|}
\hline 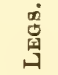 & $\begin{array}{l}\text { Homologovs } \\
\text { JorNTS. }\end{array}$ & Confficient. & Excess. & Coeffichent. & $\begin{array}{l}\text { NON-HOMOLOGOUS } \\
\text { JOINTS OF SAME LEO. }\end{array}$ \\
\hline $\begin{array}{l}\text { 回 } \\
\text { 芯 } \\
\text { 曰 }\end{array}$ & $\left.\begin{array}{r}\text { Meripodite I } \\
\text { with meripo-- } \\
\text { dite II }\left(a a^{\prime}\right) .\end{array}\right\}$ & $0.9665 \pm 0.0026$ & $\begin{array}{l}+(1.88) \\
+(7.76) \\
+(4.43) \\
-(0.89) \\
+(8.85) \\
+(10.18) \\
+(1.06) \\
-(0.23)\end{array}$ & $\begin{array}{r}0.9588 \pm 0.0032 \\
.9083 \pm .0070 \\
.9439 \pm .0044 \\
.9696 \pm .0024 \\
.9083 \pm .0070 \\
.8742 \pm .0095 \\
.9696 \pm .0024 \\
.9736 \pm .0021\end{array}$ & $\begin{array}{l}\text { Meripodite I with car- } \\
\text { popodite I }(a b) \text {. } \\
\text { Meripodite II with car- } \\
\text { popodite II }\left(a^{\prime} b^{\prime}\right) \text {. } \\
\text { Meripodite I with } \\
\text { propodite I }(a c) \text {. } \\
\text { Meripodite II (with } \\
\text { propodite II }\left(a^{\prime} c^{\prime}\right) \text {. } \\
\text { Meripodite II with car- } \\
\text { popodite III }\left(a^{\prime} b^{\prime}\right) \text {. } \\
\text { Meripodite III with car- } \\
\text { popodite III }\left(a^{\prime \prime} b^{\prime \prime}\right) \text {. } \\
\text { Meripodite II with } \\
\text { propodite II }\left(a^{\prime} c^{\prime}\right) \text {. } \\
\text { Meripodite II with } \\
\text { propodite III }\left(a^{\prime \prime} c^{\prime \prime}\right) \text {. }\end{array}$ \\
\hline & (D) 1 & & AND III & 25 & \\
\hline 岑 & $\left.\begin{array}{c}\text { Meripodite I } \\
\text { with meripo- } \\
\text { dite In }\left(a a^{\prime \prime}\right) .\end{array}\right\}$ & $0.9686 \pm 0.0025$ & $\begin{array}{l}+(2.39) \\
+(9.63) \\
+(4.84) \\
-(1.52)\end{array}$ & $\begin{array}{r}0.9588 \pm 0.0032 \\
.8742 \pm .0095 \\
.9439 \pm .0044 \\
.9736 \pm .0021\end{array}$ & $\begin{array}{l}\text { Meripodite I with car- } \\
\text { popodite I }(a b) \text {. } \\
\text { Meripodite III with car- } \\
\text { popodite III }\left(a^{\prime \prime} b^{\prime \prime}\right) \text {. } \\
\text { Meripodite I with pro- } \\
\text { podite I (ac). } \\
\text { Meripodite III with } \\
\text { propodite III }\left(a^{\prime \prime} c^{\prime \prime}\right) \text {. }\end{array}$ \\
\hline
\end{tabular}

Table 16 demonstrates that in the case of the carpopodites, on the whole, the contiguous joints of the same leg are more highly correlated than homologous joints of different legs. In only three cases out of twelve is the excess in favor of the homologous joints, and in those cases the differences are relatively small. The carpopodite correlations thus show exactly the reversed relation to what the meripodite correlations do, though the differences, as shown by the ratios in the excess column, are relatively smaller than in the former case. 
TABLE 16.

(A) CARPOPODITES OF LEGS I AND II, AND II AND III (CONTIGUOUS METAMERES).

\begin{tabular}{|c|c|c|c|c|c|}
\hline $\begin{array}{l}\text { 离 } \\
\text { 莦 }\end{array}$ & $\begin{array}{l}\text { HoMOLOGOUS } \\
\text { JoINTs. }\end{array}$ & COEFFICIENT. & Excess. & CoEfFicient. & $\begin{array}{l}\text { NON-HOMOLOGOUS } \\
\text { JOINTS OF SAME LEG. }\end{array}$ \\
\hline 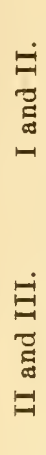 & $\begin{array}{c}\text { Carpopodite I } \\
\text { with carpo- } \\
\text { podite II } \\
\left(b b^{\prime}\right) .\end{array}$ & $0.9069 \pm 0.0071$ & $\begin{array}{l}-(6.65) \\
-(6.77) \\
-(0.14) \\
+(.32) \\
-(1.79) \\
-(1.32) \\
+(1.15) \\
+(1.05)\end{array}$ & $\begin{array}{l}0.9588 \pm 0.0032 \\
.9677 \pm .0025 \\
.9083 \pm .0070 \\
.9036 \pm .0074 \\
.9083 \pm .0070 \\
.9036 \pm .0074 \\
.8742 \pm .0095 \\
.8757 \pm .0093\end{array}$ & $\begin{array}{l}\text { Carpopodite I with } \\
\text { meripodite I (ba). } \\
\text { Carpopodite I with } \\
\text { propodite ( }(b c) \text {. } \\
\text { Carpopodite II with } \\
\text { meripodite II }\left(b^{\prime} a^{\prime}\right) \text {. } \\
\text { Carpopodite II with } \\
\text { propodite II }\left(b^{\prime} c^{\prime}\right) \text {. } \\
\text { Carpopodite II with } \\
\text { meripodite II }\left(b^{\prime} a^{\prime}\right) \text {. } \\
\text { Carpopodite II with } \\
\text { propodite II }\left(b^{\prime} c^{\prime}\right) \text {. } \\
\text { Carpopodite III with } \\
\text { meripodite III }\left(b^{\prime \prime} a^{\prime \prime}\right) \text {. } \\
\text { Carpopodite III with } \\
\text { propodite II }\left(b^{\prime \prime} c^{\prime \prime}\right) \text {. }\end{array}$ \\
\hline \multicolumn{6}{|c|}{ (B) CARPOPODITES OF LEGS I AND III (NON-CONTIGUOUS METAMERES). } \\
\hline$\underset{\Xi}{\rightleftarrows}$ & $\left.\begin{array}{l}\text { Carpopodite I } \\
\text { with carpo- } \\
\text { podite III } \\
\left(b b^{\prime \prime}\right) .\end{array}\right\}$ & $0.8685 \pm 0.0099$ & $\begin{array}{l}-(8.68) \\
-(9.73) \\
-(0.42) \\
-(.53)\end{array}$ & $\begin{array}{r}0.9588 \pm 0.0032 \\
.9677 \pm .0025 \\
.8742 \pm .0095 \\
.8757 \pm .0093\end{array}$ & $\begin{array}{l}\text { Carpopodite I with } \\
\text { meripodite I }(b a) \text {. } \\
\text { Carpopodite I with } \\
\text { propodite I }(b c) \text {. } \\
\text { Carpopodite III with } \\
\text { meripodite III }\left(b^{\prime \prime} a^{\prime \prime}\right) \text {. } \\
\text { Carpopodite III with } \\
\text { propodite III }\left(b^{\prime \prime} c^{\prime \prime}\right) \text {. }\end{array}$ \\
\hline
\end{tabular}

We have, finally, the data for the propodites in table 17 , and here we find that in the case of the propodite correlations there is nothing approaching a uniform rule of higher correlation in the homologous joint pairs over the pairs from the same leg. In seven cases out of the twelve the pairs of joints from the same leg have the higher coefficient, and in five the opposite relation holds. No stress can be laid on such a small majority, however. Turning to the amounts of the individual differences, we find for the plus difference ratios a mean value of 5.76 and for the minus ratios a mean of 3.70. The plus differences are clearly the larger on the average. 
TABLE 17.

(A) PROPODITES OF LEGS I AND II, AND II AND III (CONTIGUOOS METAMERES) .

\begin{tabular}{|c|c|c|c|c|c|}
\hline $\begin{array}{l}\text { 题 } \\
\text { 蚫 }\end{array}$ & $\begin{array}{l}\text { Homologovs } \\
\text { JoINTA. }\end{array}$ & Coefficient. & Excess. & Coefficient. & NoN-HомоLоGOUs JoINts. \\
\hline 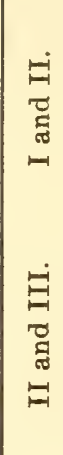 & $\left.\begin{array}{r}\text { Propodite I } \\
\text { with propo- } \\
\text { dite II }\left(\mathrm{cc}^{\prime}\right) .\end{array}\right\}$ & $0.9506 \pm 0.0039$ & $\begin{array}{l}-(3.72) \\
+(5.60) \\
+(1.14) \\
-(4.13) \\
+(7.18) \\
+(8.70) \\
-(2.21) \\
-(3.41)\end{array}$ & $\begin{array}{l}0.9677 \pm 0.0025 \\
.9036 \pm .0074 \\
.9439 \pm .0044 \\
.9696 \pm .0024 \\
.9036 \pm .0074 \\
.8757 \pm .0093 \\
.9696 \pm .0024 \\
.9736 \pm .0021\end{array}$ & $\begin{array}{l}\text { Propodite I with car- } \\
\text { popodite I }(c b) \text {. } \\
\text { Propodite II with car- } \\
\text { popodite II }\left(c^{\prime} b^{\prime}\right) \text {. } \\
\text { Propodite I with } \\
\text { meripodite I (ca). } \\
\text { Propodit II with } \\
\text { meripodite II }\left(c^{\prime} a^{\prime}\right) \text {. } \\
\text { Propodite II with car- } \\
\text { popodite II }\left(c^{\prime} b^{\prime}\right) \text {. } \\
\text { Propodite III with car- } \\
\text { popodite III }\left(c^{\prime \prime} b^{\prime \prime}\right) \text {. } \\
\text { Propodite II with } \\
\text { meripodite II }\left(c^{\prime} a^{\prime}\right) \text {. } \\
\text { Propodite II w } \text { w }^{\prime} \text {. } \\
\text { meripodite III }\left(c^{\prime \prime} a^{\prime \prime}\right) \text {. }\end{array}$ \\
\hline
\end{tabular}

(B) PROPODITES OF LEGS I AND III (NON-CONTIGUOUS METAMERES).

\begin{tabular}{|c|c|c|c|c|c|}
\hline 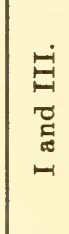 & $\left.\begin{array}{c}\text { Propodite I } \\
\text { with propo- } \\
\text { dite III (cc"). }\end{array}\right\}$ & $0.9402 \pm 0.0046$ & $\begin{array}{l}-(5.29) \\
+(6.20) \\
-(0.58) \\
-(6.55)\end{array}$ & $\begin{array}{r}0.9677 \pm 0.0025 \\
.8757 \pm .0093 \\
.9439 \pm .0044 \\
.9736 \pm .0021\end{array}$ & $\begin{array}{l}\text { Propodite I with car- } \\
\text { popodite I }(c b) \text {. } \\
\text { Propodite III with car- } \\
\text { popodite III }\left(c^{\prime \prime} b^{\prime \prime}\right) \text {. } \\
\text { Propodite I w ith } \\
\text { meripodite I }(c a) \text {. } \\
\text { Propodite III with } \\
\text { meripodite III }\left(c^{\prime \prime} a^{\prime \prime}\right) \text {. }\end{array}$ \\
\hline
\end{tabular}

Putting our results together we see that $(a)$ in the case of meripodites the influence of homology outweighs that of contiguity of parts; (b) in the case of carpopodites the positional (contiguity) influence is the greater; and finally $(c)$ in the case of propodites there is a fairly even balance between the two factors. Clearly it is impossible to lay down any rule that in general the morphological relationship implied in homology has a stronger influence in determining degree of correlation between parts than does the relative position of the parts in the organism (contiguity or separation). It would appear rather that relative position of parts and homology are about equally effective in influencing correlation. The important point, however, is that the influence of both these factors is very slight. Our results indicate that both position and homology are factors having a real influence on degree of correlation, but the amount of these influences might, on general grounds, very easily be-in fact probably has been-overrated. 
While the figures set forth in the tables of this section show that in general there is some tendency for homologous joint pairs to be more highly correlated together than are non-homologous, yet they equally show that this influence may be quite outweighed by special factors influencing particular joints. The carpopodite correlations are clear illustrations of this point. Now, there can be little doubt that these other factors which come in to influence correlations are in general factors connected with the functional relations of the parts; that is, in a broad sense, physiological factors. Perhaps the most obvious of such physiological factors is growth. In the next section it will be shown that on the average more than 50 per cent. of the observed gross correlations between the joints of the crayfish appendages is due to a true growth correlation factor. In comparison with such an effect as this it is obvious that the influence of homology on correlation is practically a negligible one. From these facts we are compelled to conclude that in comparison with physiological factors the influence of morphological relationship, as implied in homology, on correlation is relatively insignificant. This conclusion is in entire agreement with certain results which have been obtained by Davenport (1903, p. 130). Studying the correlation between the anteroposterior diameter and the dorso-ventral diameter of the lower valve of Pecten opercularis, he finds a very high degree of correlation between them. These axes are morphologically independent, but by the position which the animal takes they are brought into the same relation to the bottom. The coefficient of correlation between these two axes is in each of three samples $>0.969$. Regarding this result Davenport says:

Here the correlation coefficients of non-bilateral dimensions are extremely high, as high as in many of the highest human coefficients between bilateral dimensions. As a result of the newly assumed position of the scallop, two formerly largely independent axes have come to vary simultaneously just because they have similar relations to the bottom. Pecten has gained a new kind of symmetry; namely, a radial symmetry. The fact points very forcibly to another conclusion; namely, that physiological factors are much more important in determining correlations than morphological relationship when the two come into conflict.

Though the influence of homology on correlation is a relatively slight one, that it is nevertheless a real one is evidenced by the fact that work on other organisms than the crayfish has shown its existence. In his memoir on the variation and correlation of the human skeleton Warren (1897) includes a section on "The Correlation of Homologous Parts" (pp. 179-182) in which he discusses the relative degree of correlation between pairs of homologous and non-homologous limb bones. He finds that the 
femur and humerus are "distinctly more closely correlated" than are the femur and the radius. The tibia and radius appear to be "slightly more correlated" than the tibia and humerus. His general conclusion is that "serially homologous bones tend to be more closely correlated than nonhomologous bones." Similar results have been obtained by Lewenz and Whiteley (loc. cit.). In their study of the intercorrelations of the bones of the hand they found that homologous bones from two digits tend to be more closely correlated than contiguous bones of the same digit. Their statement (p. 350) is: "The next highest correlations* are between lateral and not between longitudinal neighbours, each bone being on the average more nearly related to the corresponding bone on the next digit, than to the adjacent bone on the same digit."

It may be said, then, that the evidence at present available indicates that the morphological relationship implied in the homology of parts is probably a real factor in influencing the degree of correlation in the variation of these parts, but that this influence is nowhere a marked one.

\section{PARTIAL CORRELATIONS.}

We have so far been discussing the gross correlations between different pairs of characters. It is of importance now to examine the "net" or "partial" correlations of the joints of the legs with one another. The nature and properties of the coefficients measuring partial correlation have been fully discussed by Pearson (1902 and earlier papers), and it will not be necessary here to discuss them in detail. We may, however, note briefly certain fundamental points in the mathematical theory of multiple correlation.

Let $x_{1}, x_{2}, x_{3}$, be any three characters of a population of organisms varying about their respective means with standard deviations $\sigma_{1}, \sigma_{2}$ and $\sigma_{3}$, and organically correlated together to the degree indicated by coefficients $r_{12}, r_{13}, r_{23}$. Then suppose a group of individuals to be selected from the population with reference to the character $x_{1}$, so that after the selection the variability of this character will be that indicated by a standard deviation $s_{1}$. It has been shown by Pearson (loc. cit.) that in this selected group of individuals the correlation between $x_{2}$ and $x_{3}$ will be given by a coefficient

$$
\mathfrak{r}_{23}=\frac{\left(r_{23}-r_{13} r_{12}\right)\left(1-\frac{s_{1}{ }^{2}}{\sigma_{1}{ }^{2}}\right)+\frac{s_{1}{ }^{2}}{\sigma_{1}{ }^{2}} r_{23}}{\sqrt{\left\{1-\left(1-\left(\frac{s_{1}}{\sigma_{1}}\right)^{2}\right) r_{12}{ }^{2}\right\}\left\{1-\left(1-\left(\frac{s_{1}}{\sigma_{1}}\right)^{2}\right) r_{13}{ }^{2}\right\}}}
$$

* The highest correlations were found to be between corresponding bones of the right and left hands. 
Now suppose that we so select our group of individuals that they shall all be exactly the same with reference to the character $x_{1}$, or, in other words, so that after selection there shall be no variation in respect to $x_{1}$. The standard deviation after selection, $s_{1}$, will thus of course be zero. Putting $s_{1}=0$ in ( $\mathrm{I}$ ) we have at once

$$
\mathfrak{r}_{23}=\frac{\left(r_{23}-r_{13} r_{12}\right)}{\sqrt{\left(1-r_{12}^{2}\right)\left(1-r_{13}^{2}\right)}}
$$

which is the well-known expression for a partial correlation coefficient. This coefficient measures the correlation between $x_{2}$ and $x_{3}$ in a group of individuals where $x_{1}$ is constant. If, for example, we let $x_{1}$ denote length of cephalothorax, $x_{2}$ length of the great chela, and $x_{3}$ length of the carpopodite of the cheliped, then $\mathfrak{r}_{23}$ measures the correlation between the last two characters in a group of individuals all having the same length of cephalothorax.

The partial correlations of the different joints of the legs with each other were studied in order to get further light on the factors which influence the degree of the gross correlations. It was decided to determine the partial correlation between every possible pair of joints available in our data when the cephalothorax length was made a constant. The length of the cephalothorax may be taken as an adequate index of the size of the body, and was on this account chosen as the character to make constant in the calculations. Calculating from (II) above, and making cephalothorax length in every case the $x_{1}$ character, we have found the system of partial correlation coefficients between the different joints of the legs given in table 18. In the calculations the gross coefficients which were substituted in equation II were kept to six places of figures.

TABLE 18. - Partial correlation coefficients between the joints of the legs, the cephalothorax length being kept constant.

\begin{tabular}{|c|c|c|c|c|c|c|c|c|c|}
\hline \multirow{2}{*}{ SEGMENT. } & \multicolumn{3}{|c|}{ Meripodite. } & \multicolumn{3}{|c|}{ CARPOPODITE. } & \multicolumn{3}{|c|}{ Propodite. } \\
\hline & I. & II. & III. & I. & II. & III. & I. & II. & III. \\
\hline Meripodite: & & & & & & & & & \\
\hline I $\ldots . . .$. & 1 & 0.7087 & 0.5963 & 0.5328 & 0.2721 & 0.2761 & 0.4570 & 0.4892 & 0.4969 \\
\hline & 0.7087 & 1 & .7722 & .5793 & .4606 & .3385 & .5669 & .7429 & .6203 \\
\hline III $\ldots . .$. & \begin{tabular}{|l}
.5968 \\
\end{tabular} & .7722 & 1 & .5647 & .3501 & .3486 & .5717 & .6184 & .6988 \\
\hline $\begin{array}{r}\text { Carpopodite: } \\
\text { I ......... }\end{array}$ & .5328 & .5793 & .5647 & 1 & .4112 & .3312 & .7200 & .5105 & .4443 \\
\hline II $\ldots \ldots$ & .2721 & .4606 & .3501 & .4112 & 1 & .5256 & .3580 & .3750 & .3713 \\
\hline III ........ & .2761 & .3385 & .3486 & .3312 & .5256 & 1 & .3204 & .3127 & .3688 \\
\hline $\begin{array}{c}\text { Propodite: } \\
\text { I......... }\end{array}$ & .4570 & .5669 & .5717 & .7200 & .3580 & .3204 & 1 & .5534 & .4605 \\
\hline II ........... & .4892 & .7429 & .6184 & .5105 & .3750 & .0204 & $\begin{array}{c}1 \\
.5534\end{array}$ & $\begin{array}{l}.32004 \\
1\end{array}$ & .5000 \\
\hline III... & .4969 & .6203 & .6988 & .4443 & .3713 & .3688 & .4605 & .5759 & 1 \\
\hline
\end{tabular}


The most striking fact about these coefficients which one notices at once is that they are uniformly considerably smaller than the corresponding gross correlation coefficients. This means that in a group of individuals all having the same length of cephalothorax the correlation is much less close between different segments of the legs than when individuals of all sizes are considered together. Or, in other words, the result shows that a considerable portion of the high gross correlations between joints arises from the fact that both the joints of the given pair are correlated with the length of the cephalothorax. When we get rid of the effect of these general "size" correlations by making cephalothorax length a constant we have left the measure of the net relationship between parts. This net correlation measures the true organic relationship which exists between a given pair of organs, quite apart from the fact that both the organs have their dimensions correlated with the size of the body as a whole. The biological interpretation of the excess of gross over partial correlation coefficients appears to us to be that it measures the portion of the total correlation, which is a true growth correlation.

It is of interest to see what proportion the partial bears to the total correlation in the case of the different legs and segments. This may be done by expressing the partial coefficient as a percentage of the total. Doing this for the three possible joint pairs of each leg, we have the result set forth in table 19.

TABLE 19. - Proportion of net to total correlation in the different legs.

\begin{tabular}{|c|c|c|c|}
\hline \multirow{2}{*}{ Segment Pair. } & \multicolumn{3}{|c|}{ Percentage of net to total Coefficient. } \\
\hline & Leg I. & Leg II. & Leg III. \\
\hline $\begin{array}{l}\text { Meripodite with carpopodite } \ldots \ldots \ldots \ldots \ldots \ldots \ldots \\
\text { Carpopodite with propodite } \ldots \ldots \ldots \ldots \ldots \ldots \ldots \\
\text { Meripodite with propodite } \ldots \ldots \ldots \ldots \ldots \ldots\end{array}$ & $\begin{array}{l}55.6 \\
74.4 \\
48.4\end{array}$ & $\begin{array}{l}50.7 \\
41.5 \\
76.6\end{array}$ & $\begin{array}{l}39.9 \\
42.1 \\
71.8\end{array}$ \\
\hline Mean... & 59.5 & 56.3 & 51.3 \\
\hline
\end{tabular}

From this table, considering first the means of the columns, we see that on the average the net correlation forms the largest proportion out of the total correlation in the ease of leg I, less in leg II, and least in leg III. Or, put in another way, the fact that the joints are correlated with cephalothorax length measuring size of body accounts for the smallest 
part of the observed total correlations between the joints in the case of leg I, and as we pass to more posterior legs the effect of this factor increases. From the individual values we begin to get a closer insight into the relative effects of the different factors influencing the intercorrelations of the joints of the legs. It is clear that leg $\mathrm{I}$ shows distinctly different relations than do legs II and III. In the case of legs II and III, a very considerable proportion ( $>50$ per cent.) of the total correlation of joint pairs involving the carpopodite as one variable arises from the fact that these joints are correlated with the length of the cephalothorax. In the joint pair which does not involve a carpopodite, a very small proportion of the total correlation is due to this "general size" factor. On the other hand, leg I shows exactly the opposite relation. There the net relation is least in the joint pair which does not involve the carpopodite and greatest in the cases where the carpopodite is included. Leg I follows an entirely different rule in the correlation of its joints than legs II and III. In leg I the bulk of the total correlation represents net organic relationship between the joints, whereas in the other legs a very large portion of the total correlation arises in an indirect way through the correlation of the joints with the size of the body as a whole.

Turning again to the values in table 18 , we have calculated the mean values of the net coefficients for the correlations between homologous joints of the different legs with the following results: Mean net correlation between homologous joints: Meripodites $=0.6926$; carpopodites $=0.4227$; propodites $=0.5299$.

For all possible pairs of non-homologous joints of contiguous legs ( 12 cases) the mean net coefficient is 0.4789 , while for the six cases of non-homologous joints of non-contiguous legs the mean is 0.4457 , or, in other words, there is no evidence in these correlations of an effect of the contiguity of metameres. From the means of the net correlations we see that just as in the case of the total correlations there is clear evidence that homologous segments tend to the more highly correlated than nonhomologous, but as before the carpopodite correlations form an exception. These results point to the conclusion that the higher gross correlations of contiguous parts arise through the growth correlation factor, while for the higher correlation of homologous parts another explanation must be sought. 


\section{INDEX CORRELATIONS.}

It has been elsewhere pointed out by the writer of this paper (Pearl 1906 and 1907) that it is of considerable theoretical importance to determine for as many organisms as possible whether there is or is not a sensible correlation between the proportionality of the parts in a differentiated system of organs and the absolute size of the system. An essential part of Driesch's so-called "first proof of the autonomy of vital phenomena" (cf. Driesch 1901) depends on the assumption that such a correlation does not exist, but that, on the other hand, proportionality of parts and absolute size are quite independent in the organism. Fortunately the matter is one which can be quantitatively tested and a definite answer reached by direct appeal to the facts. The proportionality of a series of parts can always be measured by forming from the absolute dimensions of these parts a series of indices which will give the percentage which the size of a given part is of the size of some other part or of some dimension measuring the size of the whole organism. Having determined these indices, in order to answer our question we have merely to calculate by now well-known mathematical methods the correlation between a given index and any chosen measure of the absolute size of the organism. The mathematical theory of index correlations was first investigated by Pearson (1897) and Galton (1897). A discussion and illustration of the meaning of the formulæ has been given by the present writer in another paper (Pearl 1907) and need not be repeated here. We need merely to note that if $x_{1} / x_{3}$ be any index, then the gross correlation between this index and the absolute dimension $x_{3}$ is given by the expression

$$
\rho=\frac{r_{13} v_{1}-v_{3}}{\sqrt{v_{1}^{2}+v_{3}^{2}-2 r_{13} v_{1} v_{3}}}
$$

and the spurious correlation between the two characters which exists when all organic correlation between $x_{1}$ and $x_{3}$ is destroyed is given by

$$
\rho_{0}=-\frac{v_{3}}{\sqrt{v_{1}^{2}+v_{3}^{2}}}
$$

where $r_{13}$ is the coefficient of correlation between $x_{1}$ and $x_{3}$, and $v_{1}$ and $v_{8}$ are the coefficients of variation of these two characters.

In the crayfish appendages we have a system of parts in which definite proportions are maintained with a very high degree of constancy. This is an obvious fact from even cursory observation, and quantitative proof of it is given in table 6 above. It seems an especially suitable object on which to test our question as to whether or not these proportions are correlated with the absolute size of the body. To get at the question in a 
practical way we have determined the correlations between $(a)$ the index formed by dividing the length of a joint of a given leg by the length of the cephalothorax, and $(b)$ the latter dimension, for each segment of the three legs studied. In other words, we have put for $x_{3}$ length of cephalothorax and for $x_{1}$ the length of each joint of the legs taken individually. The results are shown in table 20 .

TABLE 20.-Index correlations in the crayfish.

\begin{tabular}{|c|c|c|}
\hline Correlated Characters. & $\begin{array}{c}\text { Gross } \\
\text { CorRELAtion. }\end{array}$ & $\begin{array}{c}\text { SPURIOUS } \\
\text { CORRELATION. }\end{array}$ \\
\hline Head-Cephalothorax index, with cephalothorax... & 0.2049 & -0.6529 \\
\hline Mer. I. Cephalothorax index, with cephalothorax.. & .4213 & -.6418 \\
\hline Mer. II. Cephalothorax index, with cephalothorax. & .1965 & -.6514 \\
\hline Mer. IIl. Cephalothorax index, with cephalothorax.. & .1347 & -.6768 \\
\hline Carp. I. Cephalothorax index, with cephalothorax. . & .4879 & -.6108 \\
\hline Carp. II. Cephalothorax index, with cephalothorax. . & .2011 & -.6262 \\
\hline Carp. III. Cephalothorax index, with cephalothorax.. & .0473 & -.6408 \\
\hline Prop. I. Cephalothorax index, with cephalothorax. & .6753 & -.5207 \\
\hline Prop. II. Cephalothorax index, with cephalothorax. . & .1397 & -.6734 \\
\hline Prop. III. Cephalothorax index, with cephalothorax.. & .0617 & -.9824 \\
\hline
\end{tabular}

From this table we see that in every case the gross correlation between the index and the absolute length of the cephalothorax is positive. The values of the coefficients vary greatly for the different indices. As is to be expected for arithmetical reasons, the spurious correlation is in all cases negative (cf. formula for $\rho_{0}$ above). It is to be noted that the value of the spurious correlation runs much more closely the same for all the indices than does the gross correlation. This is, of course, what we should expect a priori, from the very fact that we are dealing with a spurious correlation; that is, one whose origin is arithmetic rather than organic.

The fact that, as shown in this table, the observed correlations between index and absolute size all have the positive sign, while the spurions correlations all have the negative sign, demonstrates the essential point at issue, namely, that there is a true organic correlation between the indices (measuring the proportions of the different parts) and the absolute size of the body as measured by the length of the cephalothorax. There is no possibility in this case of the argument being made that the interpretation of the results is doubtful, because we can not be absolutely certain as to what portion of the observed correlation is organic and what portion spurious. Here the spurious correlation must in the nature of the case be negative. But the actually observed gross correlations are in every case positive. In other words, the tendency toward a negative correlation 
indicated by the high spurious coefficients has been overcome and there is in every case an additional balance on the positive side. This shifting of the correlation from the negative direction of the spurious through zero to the positive side, as observed in the gross coefficients, can only be due to the influence of a positive organic correlation between index and absolute size. It is immaterial for the essential problem what the exact amount of this correlation is, or how it shall be measured.* The figures show beyond any doubt $(a)$ that an organic correlation between the indices and the absolute dimension exists; $(b)$ that this correlation is in the positive direction; and $(c)$ that while it varies for the different characters it is generally high, and certainly to be regarded as significant.

The relation of gross and spurious coefficients in these index correlations may be illustrated by fig. 8 .

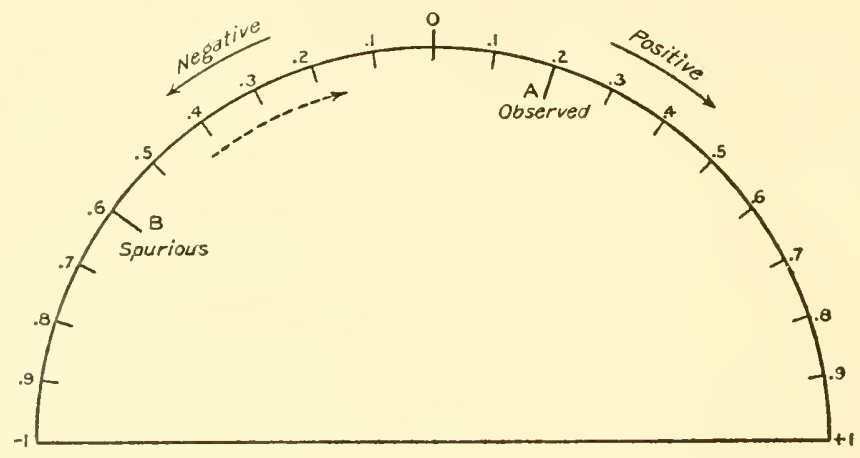

FIG. 8.- To illustrate the relation of gross and spurious coefficients in index correlation. (Explanation in text.)

In this diagram the semicircular arc is taken to represent the whole possible range of values of a correlation coefficient from -1 through 0 to +1 . The positive correlations are on the right of 0 and the negative on the left, the directions being indicated by the outside arrows. The heavy line at $A$ we may consider to represent the actual value of the correlation between an index, say, carpopodite of leg II/cephalothorax, and the length of the cephalothorax which one would find if he were to calculate the index for each individual from a correlation table, and

* Pearson has suggested the expression $\rho-\rho_{0}$ as a measure of the intensity of the "net" organic correlation, in the case of indices. It is obviously defective, in that it is not necessarily limited in the values it may take to the 0 and \pm 1 of a true coefficient of correlation. There can be no doubt, though, that in a general way it measures the "shift" of the correlation. This point has been more fully discussed and illustrated in the papers of the present writer referred to above (p. 40). 
evaluate the coefficient in the usual way. Now, if in calculating the indices the carpopodite lengths and cephalothorax lengths were put together in pairs quite at random (say the carpopodite length of individual $X$ was divided by the cephalothorax length of another individual, $Y$, instead of by its own), instead of as they actually occur, there would still be a correlation between these indices and the length of the cephalothorax. This correlation we know would be negative, and its amount may be indicated by the heavy line at $B$. Now, if there were no organic correlation between our two characters, index and absolute dimensions, obviously we should expect that the observed correlation would be that which arises for arithmetic reasons solely. In other words, we should expect observed and spurious to be equal, or, on the diagram, $A$ and $B$ to coincide. But the two are not equal. From the spurious or arithmetic correlation value at $B$ there has been a shift in the direction of the inside dotted arrow, through "no correlation" at zero to a positive correlation measured by the observed coefficient at $A$. This shift is the result of the organic correlation between the index and the absolute dimension. A study of the values of table 20 in connection with the diagram will, we believe, convince even the non-mathematical reader of the reality of the result that the proportions of the crayfish body are not independent of its absolute size, but that, instead, the two things are correlated together to a definite and significant degree.

In order to bring out in another way the generality of this result we have resorted to a still different method. We have directly determined the correlation between an index and an absolute dimension which does not enter as one of the factors in the index. In this case there is no spurious correlation; the total observed relationship is organic in origin, just as truly as the correlation between two absolute dimensions is organic. On account of the considerable arithmetical labor involved we have worked out completely only one of these cases, but it will serve to demonstrate the point made. Other examples were carried far enough to show that essentially the same results would be obtained with them, the differences being only in the numerical values of the coefficients. In order to make the tests as fair as possible the characters which were to go to form the indices were chosen at random. The first pair of characters which were drawn were $(a)$ meripodite of leg I, and $(b)$ propodite of leg I. The quotient of $a / b$ was directly calculated for each individual and entered on the record cards. Then a correlation table was formed between these 
index values as one variable, and the length of the cephalothorax as the other variable. Now, it is obvious that since cephalothorax does not enter into the index fraction, there can be no spurious correlation here. The resulting table is table 21 .

TABLE 21.-Correlation surface for the correlation between the index

Meripodite I/Propodite I, and the length of the cephalothorax.

\begin{tabular}{|c|c|c|c|c|c|c|c|c|c|c|c|c|c|c|c|c|c|c|c|}
\hline \multirow[b]{2}{*}{$\begin{array}{l}\text { INDEX IN } \\
\text { PER CENT. }\end{array}$} & \multicolumn{18}{|c|}{ Length of Cephalothorax. } & \multirow[b]{2}{*}{ TotAL } \\
\hline & 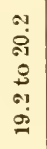 & 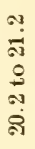 & 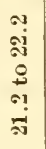 & 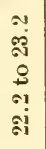 & 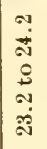 & 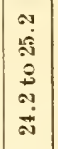 & 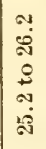 & 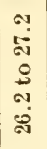 & 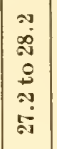 & 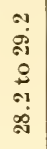 & 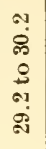 & 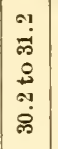 & 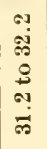 & 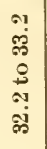 & 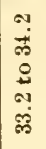 & 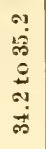 & 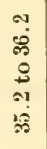 & 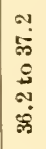 & \\
\hline $\begin{array}{l}41 \text { to } 43 . \\
43 \text { to } 45 . \\
45 \text { to } 47 . \\
47 \text { to } 49 . \\
49 \text { to } 51 . \\
51 \text { to } 53 . \\
53 \text { to } 55 . \\
55 \text { to } 57 . \\
57 \text { to } 59 . \\
59 \text { to } 61 . \\
61 \text { to } 63 .\end{array}$ & $\begin{array}{l}\because \\
\because \\
\because \\
\ddot{1} \\
\cdots \\
\cdots \\
\because \\
\cdots\end{array}$ & $\begin{array}{l}\because \\
\because \\
\ddot{1} \\
4 \\
3 \\
\therefore \\
\therefore \\
.\end{array}$ & $\begin{array}{c}\cdots \\
\ddot{1} \\
\ddot{1} \\
5 \\
2 \\
1 \\
\ddot{1} \\
.\end{array}$ & $\begin{array}{l}. . \\
\because \\
\because \\
1 \\
5 \\
9 \\
3 \\
\cdots \\
\cdots \\
\cdots\end{array}$ & $\begin{array}{r}\cdots \\
0 \\
1 \\
8 \\
11 \\
10 \\
1 \\
2 \\
1\end{array}$ & \begin{tabular}{r|}
1 \\
$\because$ \\
2 \\
17 \\
12 \\
11 \\
5 \\
2 \\
.. \\
. \\
.
\end{tabular} & $\begin{array}{r}1 \\
8 \\
13 \\
9 \\
6 \\
4 \\
3 \\
3 \\
\cdots\end{array}$ & $\begin{array}{r}0 . \\
0 \\
7 \\
14 \\
10 \\
3 \\
2 \\
2 \\
\cdots \\
\cdots\end{array}$ & $\begin{array}{r}. . \\
.5 \\
10 \\
3 \\
. . \\
\ddot{1} \\
. . \\
. . \\
. .\end{array}$ & $\begin{array}{c}3 \\
3 \\
4 \\
3 \\
3 \\
\ddot{1} \\
\ddot{1} \\
\cdots \\
\ldots\end{array}$ & $\begin{array}{l}0 \\
2 \\
7 \\
4 \\
1 \\
\cdots \\
\cdots \\
\cdots \\
\cdots \\
\cdots\end{array}$ & \begin{tabular}{c|}
1 \\
5 \\
4 \\
1 \\
1 \\
$\cdots$ \\
. \\
. \\
. \\
. \\
..
\end{tabular} & $\begin{array}{l}1 \\
2 \\
4 \\
2 \\
1 \\
. . \\
i \\
\text {. } \\
\therefore \\
. .\end{array}$ & 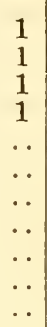 & $\begin{array}{l}1 \\
1 \\
. \\
. \\
\because . \\
\cdots \\
\because \\
\because \\
\therefore \\
\therefore\end{array}$ & 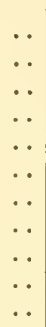 & $\begin{array}{l}\cdots \\
\cdots \\
\cdots \\
\cdots \\
\cdots \\
\cdots \\
\cdots \\
\cdots \\
\cdots \\
.\end{array}$ & $\begin{array}{l}1 \\
\cdots \\
\cdots \\
\cdots \\
\cdots \\
\cdots \\
\cdots \\
\cdots \\
\cdots\end{array}$ & $\begin{array}{r}5 \\
16 \\
44 \\
74 \\
58 \\
49 \\
21 \\
9 \\
5 \\
1 \\
1\end{array}$ \\
\hline Total. & 1 & 8 & 11 & $\overline{18}$ & 35 & 50 & 44 & 38 & 19 & 15 & 14 & 12 & $\overline{11}$ & 4 & 2 & $\ldots$ & . & 1 & 283 \\
\hline
\end{tabular}

This table shows at once that there is a distinct correlation between the two variables, and that this correlation is negative. Calculating from the frequency distribution given by this table and using Sheppard's correction of the second moment, we find the following values for the mean and variability of the index:

Mean index $=49.428 \pm 0.133$

Standard deviation of index $=3.325 \pm .094$

For the correlation between the index and absolute dimensions, length of cephalothorax we find

$$
r=-0.4621 \pm 0.0397
$$

This is clearly a sensible value in comparison with its probable error, and we must conclude, since there is no possibility here of any spurious or "arithmetic" correlation, that there is a real organic correlation between the index formed by dividing the length of the meripodite of the cheliped by the length of the propodite of the sume leg, and the absolute size of the body as measured by the length of the cephalothorax. In other words, the proportion existing between the length of the meripodite and 
that of the propodite of leg I is not the same on the average in large crayfish that it is in small. On the contrary, the proportion of these two joints relative to each other, changes in a definite and orderly manner as we pass from small to large individuals. By taking the indices formed by the lengths of other joints of the legs we should reach the same conclusion from them, the numerical values of the coefficients differing, of course, in each different case.

An essential part of Driesch's vitalistic argument appears to depend on the assumption that the proportionality of the parts in a differentiated system is independent of the size of the system. As a result of quantitative studies of the proportionality of various parts and characters of the body it has been shown that the proportions and absolute size are not independent, but instead are correlated to a sensible degree in the following organisms: Chilomonas and Paramecium (Pearl 1906 and 1907); the crayfish (the present paper); in the aphid Hyalopterus trirhodus (Warren 1902); and in the case of various proportions of the human skull by Fawcett (1902) and Macdonell (1904). The writer has in hand unpublished data showing the same thing for several other organisms. It is not our purpose to enter here upon a theoretical discussion of Driesch's "first proof," as the writer's position has already been set forth elsewhere (loc. cit.). Our present aim is merely to give in detail the additional evidence afforded by this study of the crayfish on the point made in the earlier paper. Putting all the evidence together, it would appear that the assumption that proportionality is independent of absolute size in the organism is not substantiated when an exact quantitative study of the facts is made. Only by such quantitative study can it be determined with any degree of precision whether or not there is a definite association between two varying phenomena. 


\section{SUMMARY OF RESULTS AND CONCLUSIONS.}

This study, dealing with eleven characters of the body and appendages of the crayfish, had for its primary purpose the determination of the relation of variation and correlation to the morphological factors, differentiation and homology. The results and the conclusions drawn therefrom may be summarily stated as follows:

(1) Variation in all the characters studied is skew rather than symmetrical in its distribution. The skewness is in all cases positive, or the mean lies above the mode. In respect to the degree of flat-toppedness or kurtosis the variation curves all deviate from the mesokurtic condition of the normal curve. In general, we conclude that the variation in the characters of the crayfish studied can not possibly be adequately described by the normal or Gaussian curve of errors.

(2) The correlations between the different characters studied are generally of an unusually high order of magnitude. The coefficients are in general of about the same magnitude as those which have been found for the correlation between bilaterally homologous organs in other animals. The regressions are linear throughout.

(3) It is found that the cheliped, which is the most differentiated leg, is more variable in all the joints studied than is either the first or the second ambulatory appendage. This result is obtained whether we measure the variation in the absolute size of the organs or in their relative proportions when referred to some other dimension of the body as a standard base.

(4) The most variable and the most differentiated and specialized single part of all those studied is the great chela.

(5) The frequency distributions for the different joints of the cheliped have, on the average, the greatest skewness of any of the characters studied. Degree of skewness and degree of relative variability appear to run parallel in the variation of the characters we have considered.

(6) The correlation between the homologous segments of two legs is higher when these legs are contiguous than when they are separated by an intervening leg. In so far, the crayfish furnishes evidence in favor of a "rule of neighborhood" in correlation such as has been found by Lewenz and Whiteley in the correlations of the bones of the human hand.

(7) When the correlations of the non-homologous joints of the different legs are considered such a "rule of neighborhood" is not found to hold uniformly. 
(8) The evidence as a whole points to the conclusion that homology is a factor of relatively very slight importance in determining degree of correlation between parts. In the case of certain joints of the legs (the meripodites) homologous joint pairs are significantly more highly correlated together than are non-homologous joints. Such a relation does not hold uniformly for all joints, however, and, furthermore, in the cases where it does obtain the differences between homologous and non-homologous joint pairs in respect to degree of intercorrelation are absolutely very small. The results indicate that, as compared with physiological factors, morphological relationship is, for practical purposes, a factor of negligible significance in influencing degree of correlation between parts.

(9) A study oi the partial correlations between the joints of the legs when the cephalothorax length is kept constant leads to the conclusion that a very considerable part of the gross observed correlations between the different segments of the legs arises through the high correlation between the size of these segments and the size of the body as a whole. In other words, it appears that the degree of gross correlation between parts in the crayfish is in each case the resultant of two sets of influences. There is first a general growth correlation factor which accounts for a considerable part, but not all, of the observed gross correlation. Besides this growth correlation sensu strictu, there is left a portion of the gross correlation, to account for which other physiological factors must be adduced. In the analysis of these factors by experimental investigation lies the hope of progress in the problem of the origin of organic correlation.

(10) The data show that in the crayfish there is in general a substantial degree of correlation between the proportionality of the parts and the absolute size of the organism. We are thus able to add one more to the list of organisms in which this relationship has been shown by quantitative methods to be true. The bearing of this result on certain of Driesch's theoretical deductions regarding a vitalistic hypothesis is discussed. 
TABLES OF MEASUREMENTS.

The fifty-five correlation tables which furnish the data for this paper are given in the present section. In each case the measurements are given in millimeters. In order to save space a special rubric is not given for each table. Instead, on the top and left side of each table are stated the two characters whose correlation is given by the table. The plan according to which the tables have been arranged will be selfevident on inspection.

TABLE 22.

\begin{tabular}{|c|c|c|c|c|c|c|c|c|c|c|c|c|c|c|c|c|c|c|c|}
\hline \multirow[b]{2}{*}{$\begin{array}{c}\text { LENaTh } \\
\text { OF } \\
\text { MERIPODITE. }\end{array}$} & \multicolumn{19}{|c|}{ Cephalothorax Length. } \\
\hline & 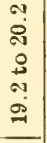 & 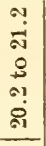 & 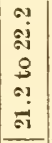 & 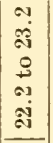 & 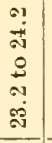 & 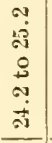 & 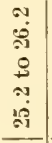 & $\begin{array}{c}01 \\
\vdots \\
51 \\
0 \\
0 \\
0 ! \\
01 \\
01 \\
01\end{array}$ & 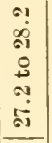 & 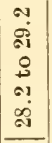 & 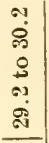 & $\begin{array}{c}01 \\
\dot{m} \\
0 \\
\dot{3} \\
01 \\
8 \\
8\end{array}$ & 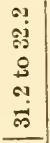 & 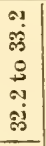 & 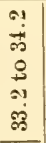 & 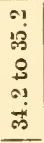 & 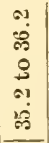 & 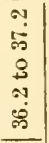 & 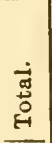 \\
\hline $\begin{array}{r}\text { LEG I. } \\
6.9 \text { to } 7.4 \ldots \\
7.4 \text { to } 7.9 . \ldots \\
7.9 \text { to } 8.4 \ldots \\
8.4 \text { to } 8.9 . \ldots \\
8.9 \text { to } 9.4 . \\
9.4 \text { to } 9.9 . \ldots \\
9.9 \text { to } 10.4 \ldots \\
10.4 \text { to } 10.9 . \ldots \\
10.9 \text { to } 11.4 \ldots \\
11.4 \text { to } 11.9 . \\
11.9 \text { to } 12.4 \ldots \\
12.4 \text { to } 12.9 . \ldots \\
12.9 \text { to } 13.4 \ldots \\
13.4 \text { to } 13.9 . \\
13.9 \text { to } 14.4 \ldots \\
14.4 \text { to } 14.9 .\end{array}$ & 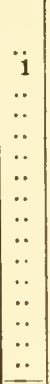 & \begin{tabular}{c|}
1 \\
5 \\
1 \\
1 \\
.. \\
. \\
. \\
. \\
. \\
. \\
. \\
. \\
. \\
. \\
.. \\
\end{tabular} & 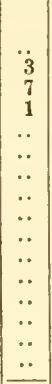 & 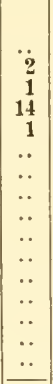 & $\begin{array}{r}2 \\
\ddot{9} \\
20 \\
4 \\
. . \\
. \\
. . \\
. . \\
. \\
. \\
. \\
. . \\
\end{array}$ & 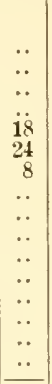 & $\begin{array}{c}22 \\
17 \\
4 \\
. \\
\ddot{.} \\
\ddot{1} \\
. \\
\because \\
\because \\
.\end{array}$ & 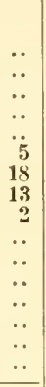 & $\begin{array}{c}. . \\
. . \\
. . \\
\ddot{3} \\
7 \\
8 \\
1 \\
. \\
\because \\
\because \\
\because \\
.\end{array}$ & $\begin{array}{c}. . \\
. . \\
. . \\
. . \\
\ddot{2} \\
9 \\
4 \\
. \\
\ddot{.} \\
\because \\
\because .\end{array}$ & 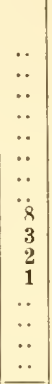 & $\begin{array}{l}. . \\
\ddot{.} \\
. \\
. \\
. \\
. \\
\ddot{.} \\
\ddot{1} \\
7 \\
\dot{4} \\
. \\
\ddot{.} \\
. \\
\end{array}$ & $\begin{array}{l}. . \\
. . \\
. \\
. \\
. \\
. \\
. \\
\ddot{3} \\
6 \\
. \\
. \\
. \\
. .\end{array}$ & $\begin{array}{l}. . \\
. \\
. . \\
. . \\
\ddot{.} \\
\ddot{.} \\
\ddot{.} \\
\ddot{4} \\
. . \\
. . \\
.\end{array}$ & 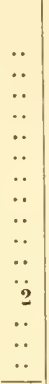 & $\begin{array}{l}. . \\
. \\
. \\
\ddot{.} \\
\ddot{.} \\
\ddot{.} \\
\ddot{.} \\
\ddot{.} \\
\ddot{.} \\
\ddot{.} \\
. . \\
\end{array}$ & 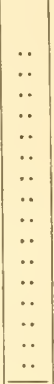 & $\begin{array}{l}. \ddot{ } \\
\ddot{.} \\
\ddot{.} \\
. \\
\ddot{.} \\
\ddot{.} \\
\ddot{.} \\
\ddot{.} \\
\ddot{i} \\
\end{array}$ & $\begin{array}{r}1 \\
13 \\
9 \\
25 \\
39 \\
55 \\
46 \\
26 \\
27 \\
8 \\
12 \\
12 \\
8 \\
.8 \\
\because\end{array}$ \\
\hline Total. & 1 & 8 & 11 & 18 & 35 & 50 & 44 & 38 & 19 & 15 & 14 & 12 & 11 & 4 & & & .. & 1 & 283 \\
\hline $\begin{array}{l}\text { LEG II. } \\
5.5 \text { to } 5.9 . . \\
5.9 \text { to } 6.3 . \\
6.3 \text { to } 6.7 . \\
6.7 \text { to } 7.1 . \\
7.1 \text { to } 7.5 . \\
7.5 \text { to } 7.9 . \\
7.9 \text { to } 8.3 . \\
8.3 \text { to } 8.7 . \\
8.7 \text { to } 9.1 . \\
9.1 \text { to } 9.5 . \\
9.5 \text { to } 9.9 . \\
9.9 \text { to } 10.3 . \\
10.3 \text { to } 10.7 . \\
10.7 \text { to } 11.1 . \\
11.1 \text { to } 11.5 .\end{array}$ & 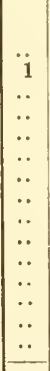 & $\begin{array}{c}2 \\
5 \\
1 \\
. \\
\because \\
\because \\
\because \\
\because \\
\because \\
\because . \\
\because . \\
\because \\
. \\
\end{array}$ & 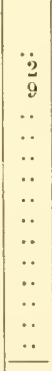 & 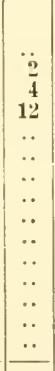 & $\begin{array}{c}\ddot{1} \\
3 \\
16 \\
10 \\
1 \\
. . \\
\because \\
\because \\
\because \\
\because \\
\because . \\
\because . . \\
\end{array}$ & $\begin{array}{c}. . \\
\because \\
7 \\
23 \\
18 \\
2 \\
. . \\
\because . \\
\because . \\
\because . \\
\because . \\
.\end{array}$ & $\begin{array}{c}\because \\
\ddot{2} \\
\ddot{6} \\
19 \\
14 \\
1 \\
1 \\
1 \\
. \\
\because \\
\because \\
\because . \\
\end{array}$ & 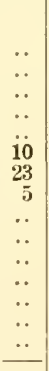 & $\begin{array}{c}. . \\
. . \\
\ddot{1} \\
1 \\
7 \\
8 \\
2 \\
. \\
. \\
\because \\
. \\
. . \\
. .\end{array}$ & $\begin{array}{c}\because . \\
. \\
. \\
. \\
\because . \\
\overrightarrow{6} \\
7 \\
. \\
\because \\
\because \\
\because . \\
. . \\
\end{array}$ & 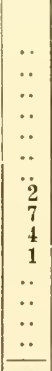 & 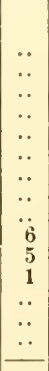 & $\begin{array}{l}\ddot{.} \\
\therefore \\
. \\
. \\
. \\
. \\
. \\
\ddot{2} \\
6 \\
2 \\
1 \\
. . \\
. .\end{array}$ & 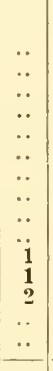 & $\begin{array}{c}. . \\
. \\
. \\
. \\
. \\
. \\
. \\
\ddot{.} \\
\ddot{1} \\
1 \\
. . \\
. . \\
\end{array}$ & 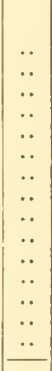 & $\begin{array}{l}\ddot{.} \\
\ddot{.} \\
\ddot{.} \\
\ddot{.} \\
\ddot{.} \\
\ddot{.} \\
\ddot{.} \\
\ddot{.} \\
\end{array}$ & $\begin{array}{l}\vdots \\
\vdots \\
\vdots \\
\vdots\end{array}$ & $\begin{array}{r}11 \\
18 \\
35 \\
45 \\
49 \\
48 \\
22 \\
17 \\
19 \\
13 \\
5\end{array}$ \\
\hline & 1 & 8 & 11 & 18 & 35 & 50 & 44 & 38 & 19 & 15 & 14 & 12 & 11 & 4 & 2 & .. & .. & 1 & 283 \\
\hline $\begin{array}{r}\text { LEG III } \\
6.3 \text { to } 6.7 \\
6.7 \text { to } 7.1 \\
7.1 \text { to } 7.5 \\
7.5 \text { to } 7.9 \\
7.9 \text { to } 8.3 \\
8.3 \text { to } 8.7 \\
8.7 \text { to } 9.1 \\
9.1 \text { to } 9.5 \\
9.5 \text { to } 9.9 \\
9.9 \text { to } 10.3 \\
10.3 \text { to } 10.7 \\
10.7 \text { to } 11.1 \\
11.1 \text { to } 11.5 \\
11.5 \text { to } 11.9 \\
11.9 \text { to } 12.3 \\
12.3 \text { to } 12.7\end{array}$ & $\begin{array}{l}\because . \\
\because . \\
\because . \\
\because . \\
\because . \\
\because . \\
\because . \\
\because . \\
\because . \\
\end{array}$ & $\begin{array}{c}1 \\
4 \\
3 \\
. \\
. . \\
. \\
. \\
. \\
. \\
. \\
. \\
\because \\
\because \\
\because . \\
. \\
\end{array}$ & $\begin{array}{l}\ddot{3} \\
7 \\
1 \\
. . \\
. \\
. \\
. \\
. \\
. \\
. \\
. \\
. \\
. \\
\end{array}$ & $\begin{array}{c}\because \\
\ddot{6} \\
10 \\
2 \\
\because . \\
\because \\
\because \\
\because \\
\because \\
\because \\
\because \\
\because \\
.\end{array}$ & $\begin{array}{c}\ddot{1} \\
2 \\
12 \\
14 \\
6 \\
. . \\
. \\
\because \\
\because \\
. \\
\because \\
\because \\
. .\end{array}$ & 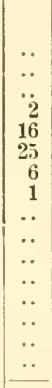 & 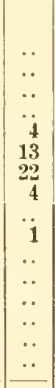 & $\begin{array}{c}\because \\
\because \\
\because \\
\ddot{4} \\
16 \\
17 \\
1 \\
. . \\
\because \\
\because \\
\because \\
\because \\
. . \\
\end{array}$ & 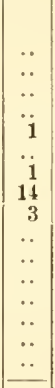 & $\begin{array}{l}\because . \\
\because . \\
\because \\
\because . \\
\because \\
4 \\
8 \\
3 \\
\because \\
\because \\
\because \\
\because \\
\because . \\
\end{array}$ & $\begin{array}{c}. . \\
\because \\
. \\
. \\
\ddot{1} \\
\ddot{1} \\
5 \\
4 \\
3 \\
1 \\
. . \\
. . \\
. .\end{array}$ & $\begin{array}{l}\because . \\
\because \\
\because \\
\because \\
\because \\
\because \\
3 \\
3 \\
1 \\
1 \\
\because . \\
\because \\
\because \\
\end{array}$ & 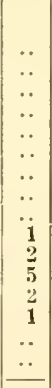 & \begin{tabular}{|c|}
$\ddot{.}$ \\
$\ddot{.}$ \\
$\ddot{.}$ \\
$\ddot{.}$ \\
$\ddot{.}$ \\
$\ddot{.}$ \\
$\ddot{2}$ \\
$\ddot{2}$ \\
$\ddot{.}$ \\
\end{tabular} & \begin{tabular}{l|}
$\ddot{.}$ \\
$\ddot{.}$ \\
$\ddot{.}$ \\
$\ddot{.}$ \\
$\ddot{.}$ \\
$\ddot{.}$ \\
$\ddot{2}$ \\
$\ddot{.}$ \\
$\ddot{.}$ \\
\end{tabular} & 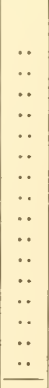 & 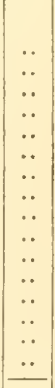 & $\begin{array}{l}\because . \\
\because . . \\
\because . \\
\because . \\
\because . \\
\because . \\
\because . \\
\because . \\
\ddot{1} \\
\end{array}$ & $\begin{array}{l} \\
1 \\
2 \\
3 \\
4 \\
4 \\
4 \\
1 \\
1 \\
1\end{array}$ \\
\hline Total. . & 1 & 8 & 11 & 18 & 35 & 50 & 44 & 38 & 19 & 15 & 14 & 12 & 11 & 4 & 2 & .. & .. & 1 & 283 \\
\hline
\end{tabular}


TABLES OF MEASUREMENTS.

Table 22.-Continued.

\begin{tabular}{|c|c|c|c|c|c|c|c|c|c|c|c|c|c|c|c|c|c|c|c|}
\hline \multirow[b]{2}{*}{$\begin{array}{c}\text { Length } \\
\text { OF } \\
\text { CaRPopodite. }\end{array}$} & \multicolumn{19}{|c|}{ Cephalothorax Length. } \\
\hline & 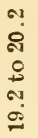 & $\begin{array}{l}\text { ?] } \\
\dot{a} \\
\stackrel{5}{1} \\
\text { ọ } \\
\dot{8}\end{array}$ & 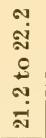 & 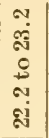 & 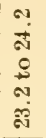 & 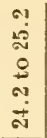 & 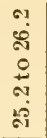 & 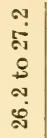 & 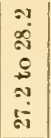 & 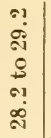 & 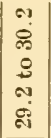 & 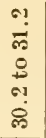 & 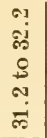 & 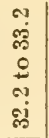 & 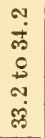 & 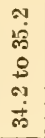 & 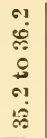 & 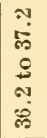 & 远 \\
\hline 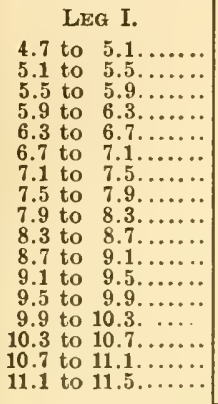 & 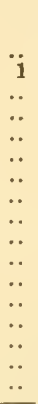 & $\begin{array}{c}\ddot{2} \\
4 \\
2 \\
. . \\
. \\
\because \\
\because \\
\because . \\
\because \\
\because \\
\because \\
\because \\
\because \\
. .\end{array}$ & $\begin{array}{c}1 \\
\ddot{5} \\
\tilde{5} \\
\ddot{.} \\
\ddot{.} \\
\ddot{.} \\
\because \\
\because \\
\because \\
\because \\
\ddot{ } \\
\ddot{.} \\
\end{array}$ & $\begin{array}{c}. . \\
\ddot{3} \\
\mathbf{9} \\
6 \\
. . \\
. . \\
. \\
. \\
. \\
. \\
. \\
. \\
. \\
. \\
. \\
. . \\
\end{array}$ & $\begin{array}{r}\ddot{2} \\
\ddot{3} \\
3 \\
11 \\
11 \\
1 \\
. . \\
\because \\
\because \\
\because \\
\because \\
\because \\
\because \\
\because \\
\because \\
\end{array}$ & 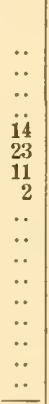 & $\begin{array}{c}. . \\
\because . \\
\ddot{2} \\
\ddot{2} \\
12 \\
21 \\
7 \\
1 \\
1 \\
. . \\
. \\
. \\
. \\
. \\
. . \\
\end{array}$ & 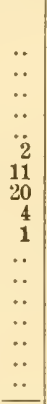 & 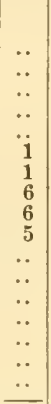 & 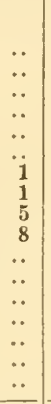 & $\begin{array}{l}. . \\
. . \\
. . \\
. . \\
. . \\
. . \\
\ddot{3} \\
6 \\
3 \\
2 \\
. . \\
. . \\
. . \\
. . \\
. . \\
\end{array}$ & $\begin{array}{c}. . \\
. \\
. \\
. \\
\because \\
\because \\
\because . \\
\ddot{1} \\
\ddot{3} \\
6 \\
2 \\
. \\
. \\
. \\
. . \\
\end{array}$ & $\begin{array}{l}\because . . \\
\because . \\
\because . \\
\because . \\
\because . \\
\because . \\
\ddot{1} \\
4 \\
3 \\
3 \\
. . \\
\because . \\
. \\
\end{array}$ & 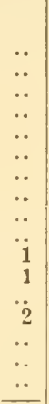 & 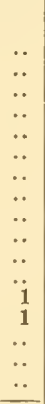 & 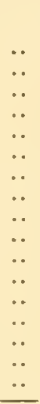 & 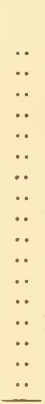 & $\begin{array}{l}\because \\
\because \\
\because \\
\because \\
\because \\
\because \\
\because \\
\because \\
\because \\
\because \\
\because \\
\because \\
.\end{array}$ & $\begin{array}{r}1 \\
5 \\
12 \\
19 \\
40 \\
49 \\
46 \\
36 \\
20 \\
22 \\
11 \\
12 \\
6 \\
3 \\
. . \\
\ddot{1}\end{array}$ \\
\hline Total....... & 1 & 8 & 11 & 18 & 35 & 50 & 44 & 38 & 19 & 15 & 14 & 12 & 11 & 4 & 2 & .. & .. & 1 & 283 \\
\hline 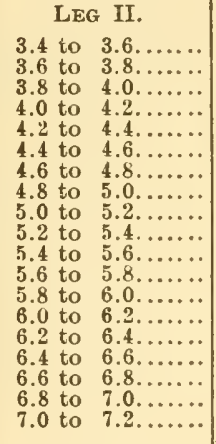 & $\begin{array}{l}\ddot{1} \\
\ddot{1} \\
\ddot{.} \\
\ddot{.} \\
\ddot{.} \\
\ddot{.} \\
\ddot{.} \\
\ddot{.} \\
\ddot{.} \\
\ddot{.} \\
\ddot{.}\end{array}$ & 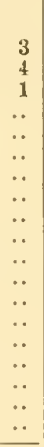 & 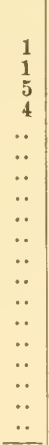 & 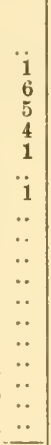 & $\begin{array}{r}\ddot{1} \\
6 \\
6 \\
11 \\
9 \\
2 \\
\because . \\
\because . \\
\because . \\
\because . \\
\because . \\
\because . \\
\because . \\
\because . \\
\because \\
\because . \\
.\end{array}$ & $\begin{array}{r}13 \\
16 \\
17 \\
2 \\
1 \\
. . \\
. \\
. . \\
. . \\
. \\
. \\
. \\
. \\
. . \\
\end{array}$ & 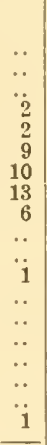 & $\begin{array}{r}. . \\
\ddot{.} \\
\ddot{1} \\
1 \\
7 \\
18 \\
8 \\
2 \\
. . \\
. . \\
. . \\
. \\
\ddot{1} \\
. . \\
. . \\
. .\end{array}$ & 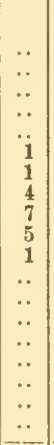 & 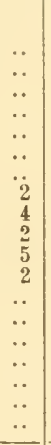 & 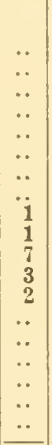 & 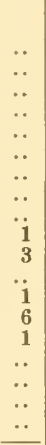 & $\begin{array}{l}\because . . \\
\because . \\
\because . \\
\because . \\
. . \\
\because . \\
\because . \\
\because . \\
3 \\
4 \\
\ddot{4} \\
. . \\
\because . \\
. . \\
\end{array}$ & 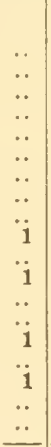 & 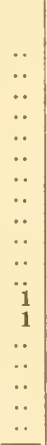 & 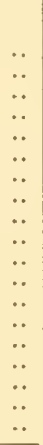 & 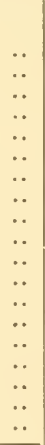 & $\begin{array}{l}\because \\
\because . \\
\because . \\
\because . \\
\because \\
\because . \\
\because \\
\because . \\
\because . \\
\because . \\
\because \\
\ddot{1} \\
\because \\
\end{array}$ & $\begin{array}{r}4 \\
7 \\
20 \\
17 \\
31 \\
37 \\
37 \\
40 \\
27 \\
12 \\
16 \\
10 \\
8 \\
7 \\
6 \\
1 \\
2 \\
\ddot{1}\end{array}$ \\
\hline Total....... & 1 & 8 & 11 & 18 & 35 & 50 & 44 & 38 & 19 & 15 & 14 & 12 & 11 & 4 & 2 & .. & .. & 1 & 283 \\
\hline 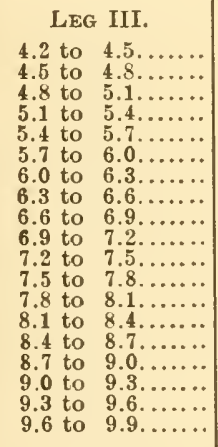 & 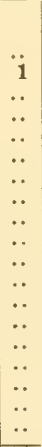 & $\begin{array}{c}1 \\
2 \\
5 \\
. . \\
\because . . \\
. . \\
. . \\
. . \\
. . \\
. . \\
. . \\
. . \\
. . \\
. . \\
. . \\
. . \\
\end{array}$ & $\begin{array}{c}1 \\
1 \\
5 \\
3 \\
1 \\
. . \\
. . \\
. . \\
. . \\
. . \\
. . \\
. . \\
. . \\
. . \\
. . \\
. . \\
\end{array}$ & 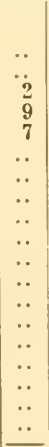 & 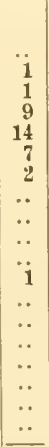 & 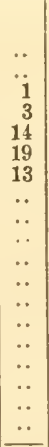 & $\begin{array}{r}\ddot{.} \\
\ddot{.} \\
\ddot{3} \\
13 \\
19 \\
7 \\
\ddot{1} \\
. . \\
. . \\
. . \\
. . \\
. . \\
\ddot{1} \\
. . \\
\end{array}$ & 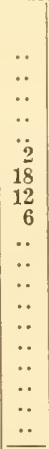 & 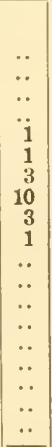 & 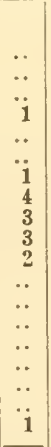 & 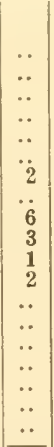 & $\begin{array}{c}\because . . \\
\because . \\
\because . \\
\because . \\
\because . \\
\ddot{2} \\
1 \\
1 \\
5 \\
3 \\
1 \\
. . \\
\because . \\
\because . \\
\because . . \\
\end{array}$ & $\begin{array}{c}. . \\
. . \\
. . \\
. . \\
. . \\
\because . \\
. . \\
\ddot{1} \\
5 \\
4 \\
1 \\
. . \\
. \\
. \\
. \\
. .\end{array}$ & 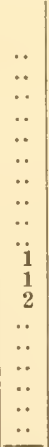 & $\begin{array}{c}. . \\
. . \\
. \\
. \\
. \\
\ddot{.} \\
\ddot{.} \\
. \\
\ddot{1} \\
\mathbf{1} \\
. \\
. \\
. \\
\because \\
. . \\
\end{array}$ & 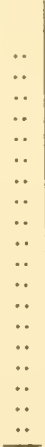 & 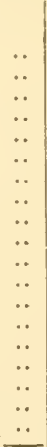 & 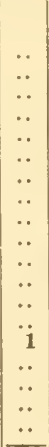 & $\begin{array}{r}2 \\
5 \\
14 \\
25 \\
40 \\
42 \\
58 \\
33 \\
20 \\
10 \\
14 \\
12\end{array}$ \\
\hline Total....... & 1 & 8 & 11 & 18 & 35 & 50 & 44 & 38 & 19 & 15 & 14 & 12 & 11 & 4 & 2 & .. & .. & 1 & 283 \\
\hline
\end{tabular}


TABLE 22.-Continued.

\begin{tabular}{|c|c|c|c|c|c|c|c|c|c|c|c|c|c|c|c|c|c|c|c|}
\hline \multirow[b]{2}{*}{$\begin{array}{c}\text { LENGTH } \\
\text { OF } \\
\text { PROPODITE }\end{array}$} & \multicolumn{19}{|c|}{ CEPHalothorax LeNGTh } \\
\hline & 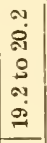 & 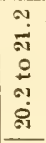 & 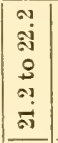 & 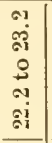 & 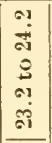 & $\mid \begin{array}{c}01 \\
0 \\
0 \\
0 \\
0 \\
01 \\
01 \\
01 \\
\end{array}$ & 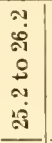 & 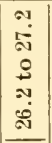 & 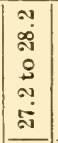 & 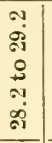 & 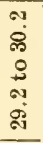 & 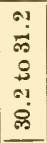 & \begin{tabular}{|c|}
$\infty$ \\
0 \\
0 \\
0 \\
0 \\
$\bar{m}$ \\
\end{tabular} & 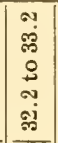 & 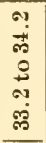 & 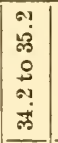 & 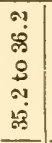 & 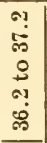 & \\
\hline 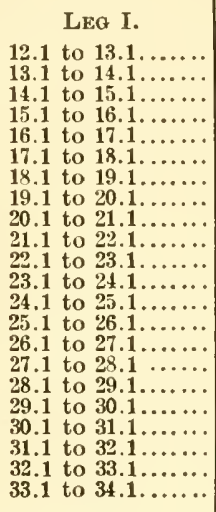 & 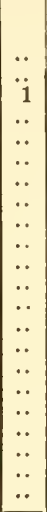 & 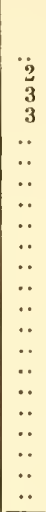 & 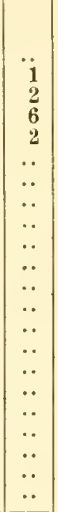 & 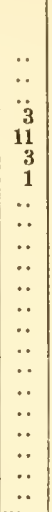 & 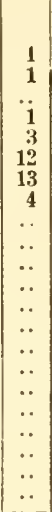 & $\begin{array}{r}. . \\
\ddot{.} \\
\ddot{2} \\
6 \\
13 \\
21 \\
5 \\
2 \\
. \\
\ddot{1} \\
. \\
\because \\
\ddot{.} \\
\ddot{.} \\
. \\
. \\
. \\
. .\end{array}$ & \begin{tabular}{r|}
$\ddot{.}$ \\
$\ddot{2}$ \\
$\ddot{1}$ \\
2 \\
5 \\
6 \\
16 \\
10 \\
2 \\
1 \\
1 \\
. \\
. \\
. \\
. \\
. \\
. \\
. \\
..
\end{tabular} & 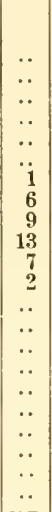 & 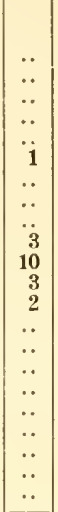 & \begin{tabular}{c|}
$\ddot{.}$ \\
$\ddot{.}$ \\
$\ddot{.}$ \\
$\ddot{1}$ \\
$\ddot{1}$ \\
1 \\
1 \\
6 \\
3 \\
2 \\
. \\
. \\
$\ddot{.}$ \\
. \\
. \\
. \\
.
\end{tabular} & $\begin{array}{l}. . \\
. . \\
. \\
. . \\
. . \\
. . \\
. \\
. \\
\ddot{4} \\
5 \\
1 \\
2 \\
2 \\
. \\
. \\
. \\
. \\
. .\end{array}$ & 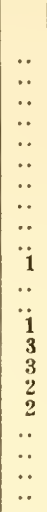 & $\begin{array}{l}\because \ddot{ } \\
\because . \\
\ddot{.} \\
\ddot{.} \\
\ddot{.} \\
\ddot{.}\end{array}$ & $\begin{array}{l}\ddot{.} \\
\ddot{.} \\
\ddot{.} \\
\ddot{.} \\
\ddot{.} \\
\ddot{.} \\
\ddot{.} \\
\ddot{1} \\
\ddot{1} \\
\ddot{2} \\
\ddot{.} \\
. .\end{array}$ & $\begin{array}{l}\ddot{.} \\
\ddot{.} \\
\ddot{.} \\
\ddot{.} \\
\ddot{.}\end{array}$ & 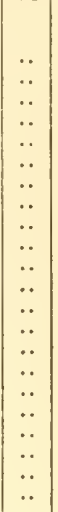 & 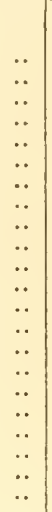 & $\ddot{i}$ & $\begin{array}{c} \\
13 \\
19 \\
2 \\
3 \\
37 \\
31\end{array}$ \\
\hline Total & 1 & 8 & 11 & 18 & 35 & 50 & 44 & 38 & 19 & 15 & 14 & 12 & 11 & & & .. & .. & & 283 \\
\hline $\begin{array}{l}4.9 \text { to } 5.2 \ldots \ldots \ldots \\
5.2 \text { to } 5.5 \ldots \ldots \ldots \\
5.5 \text { to } 5.8 \ldots \ldots \ldots \\
5.8 \text { to } 6.1 \ldots \ldots \ldots \\
6.1 \text { to } 6.4 \ldots \ldots \ldots \\
6.4 \text { to } 6.7 \ldots \ldots \ldots \\
6.7 \text { to } 7.0 \ldots \ldots \ldots \\
7.0 \text { to } 7.3 \ldots \ldots \ldots \\
7.3 \text { to } 7.6 \ldots \ldots \ldots \\
7.6 \text { to } 7.9 \ldots \ldots \ldots \\
7.9 \text { to } 8.2 \ldots \ldots \ldots \\
8.2 \text { to } 8.5 \ldots \ldots \ldots \\
8.5 \text { to } 8.8 \ldots \ldots \ldots \\
8.8 \text { to } 9.1 \ldots \ldots \ldots \\
9.1 \text { to } 9.4 \ldots \ldots \ldots \\
9.4 \text { to } 9.7 \ldots \ldots \ldots \\
9.7 \text { to } 10.0 \ldots \ldots \ldots \\
10.0 \text { to } 10.3 \ldots \ldots \ldots\end{array}$ & $\begin{array}{l}\because . . \\
\because . . \\
\because . . \\
\because . . \\
\because . . \\
\because . \\
\because . \\
\because . \\
. . \\
\end{array}$ & $\begin{array}{l}1 \\
2 \\
4 \\
1 \\
. . \\
\because . \\
. . \\
. . \\
. . \\
\because . \\
\because . \\
. . \\
. . \\
. .\end{array}$ & $\begin{array}{c}\ddot{1} \\
5 \\
3 \\
2 \\
. . \\
. \\
. \\
. \\
\ddot{.} \\
. \\
. \\
\ddot{.} \\
\ddot{.} \\
.\end{array}$ & 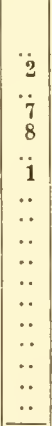 & 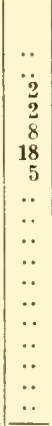 & $\begin{array}{c}. . \\
\ddot{1} \\
4 \\
19 \\
22 \\
4 \\
\ddot{.} \\
\ddot{.} \\
\ddot{.} \\
\ddot{.} \\
\ddot{.} \\
\ddot{.} \\
\end{array}$ & $\begin{array}{c}\ddot{.} \\
\ddot{2} \\
\ddot{2} \\
7 \\
13 \\
16 \\
4 \\
2 \\
\ddot{.} \\
\ddot{.} \\
\ddot{.} \\
\ddot{.} \\
\ddot{.} \\
\ddot{.} \\
\end{array}$ & $\begin{array}{r}\ddot{.} \\
\ddot{.} \\
\ddot{4} \\
\ddot{4} \\
20 \\
10 \\
4 \\
\ddot{.} \\
\ddot{.} \\
\ddot{.} \\
\ddot{.} \\
.\end{array}$ & $\begin{array}{c}\ddot{.} \\
\ddot{.} \\
\ddot{.} \\
\ddot{1} \\
\mathbf{1 1} \\
6 \\
. \\
\ddot{.} \\
\ddot{.} \\
\ddot{.} \\
\ddot{.} \\
.\end{array}$ & \begin{tabular}{l|}
$\ddot{.}$ \\
$\ddot{.}$ \\
$\ddot{.}$ \\
$\ddot{.}$ \\
$\ddot{5}$ \\
5 \\
5 \\
. \\
$\ddot{.}$ \\
$\ddot{.}$ \\
$\ddot{.}$ \\
$\ddot{.}$ \\
\end{tabular} & $\begin{array}{l}\ddot{.} \\
\ddot{.} \\
\ddot{.} \\
\ddot{.} \\
\ddot{.} \\
\ddot{4} \\
5 \\
5 \\
\ddot{.} \\
\ddot{.} \\
\ddot{.} \\
. \\
\end{array}$ & $\begin{array}{l}1 \\
1 \\
4 \\
5 \\
1 \\
. \\
. \\
. .\end{array}$ & 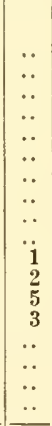 & $\begin{array}{c}\ddot{.} \\
\ddot{.} \\
\ddot{.} \\
\ddot{.} \\
\ddot{.} \\
\ddot{.} \\
\ddot{1} \\
1 \\
\ddot{1} \\
1 \\
\ddot{.} \\
\end{array}$ & $\begin{array}{l}\because . . \\
\ddot{.} \\
\ddot{1} \\
1 \\
. . \\
\because . . \\
. .\end{array}$ & $\begin{array}{l}\ddot{.} \\
\ddot{.} \\
\ddot{.} \\
\ddot{.} \\
\ddot{.} \\
\ddot{.} \\
\ddot{.} \\
\ddot{.} \\
\ddot{.}\end{array}$ & $\begin{array}{l}. . \\
. . \\
. . \\
. . \\
. \\
. \\
. \\
. \\
. \\
. \\
. \\
. \\
. \\
. \\
\end{array}$ & : & $\begin{array}{l} \\
11 \\
1 \\
4 \\
4 \\
41 \\
3 \\
2 \\
1 \\
11 \\
1\end{array}$ \\
\hline Total........ & 1 & 8 & 11 & 18 & 35 & 50 & 44 & 38 & 19 & 15 & 14 & 12 & 11 & 4 & 2 & .. & .. & 1 & 28 \\
\hline $\begin{array}{r}\text { LEG } 1 \text { III. } \\
6.6 \text { to } 7.0 . \\
7.0 \text { to } 7.4 . \\
7.4 \text { to } 7.8 . \\
7.8 \text { to } 8.2 . \\
8.2 \text { to } 8.6 . \\
8.6 \text { to } 9.0 . \\
9.0 \text { to } 9.4 . \\
9.4 \text { to } 9.8 . \\
9.8 \text { to } 10.2 . \\
10.2 \text { to } 10.6 . \\
10.6 \text { to } 11.0 . \\
11.0 \text { to } 11.4 . \\
11.4 \text { to } 11.8 . \\
11.8 \text { to } 12.2 . \\
12.2 \text { to } 12.6 . \\
12.6 \text { to } 13.0 .\end{array}$ & $\begin{array}{l}\because . . \\
\because . \\
. . \\
. . \\
. . \\
. . \\
\because . \\
\because . \\
\because . \\
. .\end{array}$ & $\begin{array}{l}\mathbf{1} \\
\mathbf{4} \\
\mathbf{3} \\
. . \\
. . \\
. . \\
. . \\
. \\
. \\
. \\
. \\
. .\end{array}$ & 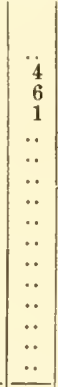 & $\begin{array}{c}\ddot{1} \\
4 \\
12 \\
1 \\
\because . \\
\because . \\
\because . \\
\because \\
\because \\
\because \\
\because \\
\because . \\
\therefore \\
\end{array}$ & $\begin{array}{r}2 \\
3 \\
11 \\
14 \\
5 \\
. . \\
\because . \\
\because \\
\because \\
\because \\
\because \\
\because \\
\because .\end{array}$ & $\begin{array}{c}. . \\
\ddot{3} \\
16 \\
25 \\
25 \\
1 \\
. \\
\because \\
\ddot{y} \\
\ddot{y} \\
\ddot{.} \\
. .\end{array}$ & 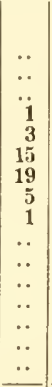 & $\begin{array}{c}. . \\
. \\
\ddot{3} \\
3 \\
18 \\
12 \\
2 \\
. \\
. \\
. \\
\because \\
. \\
. .\end{array}$ & 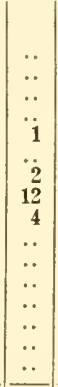 & $\begin{array}{c}\because . \\
\because \\
\because \\
\because \\
\ddot{1} \\
4 \\
6 \\
. \\
\because \\
\because \\
\because \\
\because .\end{array}$ & $\begin{array}{c}\because . \\
\because . \\
\because . \\
\because \\
\ddot{1} \\
3 \\
6 \\
4 \\
. \\
\because \\
\because \\
. .\end{array}$ & $\begin{array}{l}\because . \\
\because . \\
. . \\
. . \\
\ddot{0} \\
\ddot{0} \\
\ddot{1} \\
2 \\
5 \\
3 \\
1\end{array}$ & $\begin{array}{l}\ddot{.} \\
\ddot{~} \\
\ddot{~} \\
\ddot{~} \\
\ddot{~} \\
\ddot{1} \\
3 \\
4 \\
3\end{array}$ & \begin{tabular}{c|}
$\ddot{.}$ \\
$\ddot{.}$ \\
. \\
$\ddot{.}$ \\
$\ddot{.}$ \\
$\ddot{.}$ \\
$\ddot{.}$ \\
$\ddot{2}$ \\
$\ddot{2}$ \\
$\ddot{.}$
\end{tabular} & $\begin{array}{l}. . \\
. \\
. \\
. \\
. \\
. \\
\because \\
\because \\
. \\
\ddot{2} \\
. .\end{array}$ & 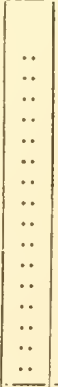 & $\begin{array}{l}\ddot{.} \\
\ddot{.} \\
\ddot{.} \\
\ddot{.} \\
\ddot{.} \\
\ddot{.} \\
\ddot{.} \\
\ddot{.} \\
\ddot{.} \\
\ddot{.} \\
\end{array}$ & 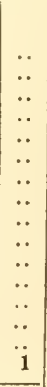 & $\begin{array}{r}12 \\
16 \\
28 \\
38 \\
48 \\
45 \\
35 \\
17 \\
13 \\
12 \\
9 \\
6 \\
2\end{array}$ \\
\hline Total....... & 1 & 8 & 11 & 18 & 35 & 50 & 44 & 38 & 19 & 15 & 14 & 12 & 11 & 4 & 2 &.$\cdot$ & & 1 & 283 \\
\hline
\end{tabular}


TABLES OF MEASUREMENTS.

Table 22.-Continued.

\begin{tabular}{|c|c|c|c|c|c|c|c|c|c|c|c|c|c|c|c|c|c|c|c|}
\hline \multirow[b]{2}{*}{$\underset{\text { BREADTH. }}{\text { HEAD }}$} & \multicolumn{19}{|c|}{ Cephalothorax length. } \\
\hline & 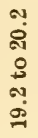 & 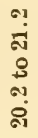 & 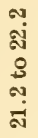 & 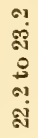 & 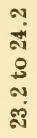 & 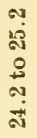 & 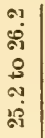 & 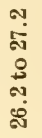 & 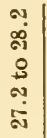 & 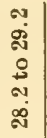 & 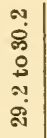 & 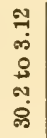 & 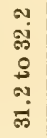 & 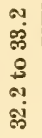 & 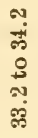 & 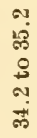 & 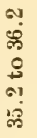 & $\begin{array}{l}9 \\
10 \\
5 \\
\dot{0} \\
01 \\
\infty \\
\infty\end{array}$ & हే \\
\hline 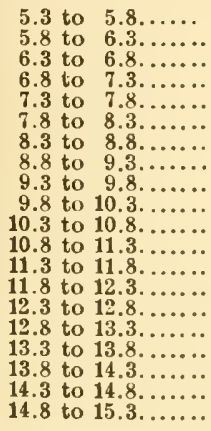 & 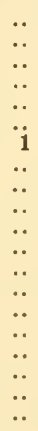 & 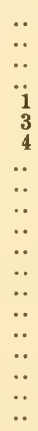 & 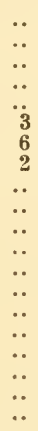 & 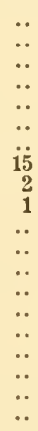 & 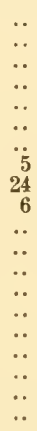 & 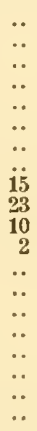 & $\begin{array}{c}\ddot{.} \\
\ddot{.} \\
\ddot{.} \\
\ddot{.} \\
\ddot{2} \\
\ddot{2} \\
10 \\
21 \\
5 \\
\ddot{1} \\
\ddot{.} \\
\ddot{.} \\
\ddot{.} \\
. .\end{array}$ & $\begin{array}{l}1 \\
\ddot{.} \\
\ddot{.} \\
\ddot{.} \\
\ddot{.} \\
\ddot{0} \\
17 \\
18 \\
\ddot{.} \\
\ddot{.} \\
\ddot{.} \\
\because \\
\because .\end{array}$ & $\begin{array}{c}\because \\
\ddot{.} \\
\ddot{.} \\
\ddot{.} \\
\ddot{.} \\
\ddot{.} \\
\ddot{4} \\
7 \\
5 \\
3 \\
\ddot{.} \\
\ddot{.} \\
\ddot{.}\end{array}$ & 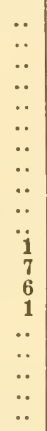 & $\begin{array}{c}. . \\
. \\
. . \\
\ddot{.} \\
\ddot{. .} \\
. . \\
. . \\
\ddot{1} \\
\ddot{1} \\
\ddot{5} \\
6 \\
2 \\
. \\
\ddot{.} \\
. .\end{array}$ & $\begin{array}{c}\ddot{.} \\
\ddot{.} \\
\ddot{.} \\
\ddot{.} \\
\ddot{.} \\
\ddot{.} \\
\ddot{1} \\
\ddot{1} \\
\ddot{1} \\
6 \\
3 \\
1 \\
\ddot{.} \\
\ddot{.}\end{array}$ & $\begin{array}{c}. . \\
\ddot{.} \\
. \\
\ddot{.} \\
\ddot{.} \\
\ddot{.} \\
\ddot{.} \\
\ddot{.} \\
\ddot{.} \\
\ddot{.} \\
\ddot{3} \\
4 \\
4 \\
\ddot{.} \\
\ddot{.}\end{array}$ & $\begin{array}{c}\ddot{.} \\
\ddot{.} \\
\ddot{.} \\
\ddot{.} \\
\ddot{.} \\
\ddot{.} \\
\ddot{.} \\
\ddot{.} \\
\ddot{.} \\
\ddot{1} \\
. \\
\ddot{.} \\
\ddot{.}\end{array}$ & 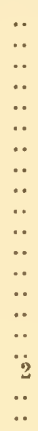 & 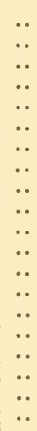 & 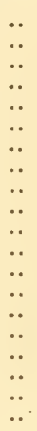 & $\begin{array}{c}. . \\
\ddot{.} \\
. \\
\ddot{.} \\
\ddot{.} \\
\ddot{.} \\
\ddot{.} \\
\ddot{.} \\
\ddot{.} \\
\ddot{.} \\
\ddot{.} \\
\ddot{i}\end{array}$ & $\begin{array}{r}1 \\
. . \\
\ddot{.} \\
\ddot{1} \\
6 \\
11 \\
22 \\
43 \\
47 \\
53 \\
34 \\
12 \\
16 \\
16 \\
10 \\
8 \\
2 \\
\ddot{1}\end{array}$ \\
\hline Total....... & 1 & 8 & 11 & 18 & 35 & 50 & 44 & 38 & 19 & 15 & 14 & 12 & 11 & 2 & 2 & .. & .. & 1 & 283 \\
\hline
\end{tabular}


TABLE 23.

\begin{tabular}{|c|c|c|c|c|c|c|c|c|c|c|c|c|c|c|c|c|c|c|c|c|c|}
\hline \multirow[b]{2}{*}{$\begin{array}{l}\text { LENGTH } \\
\text { OF } \\
\text { MERIPO. } \\
\text { DITE. }\end{array}$} & \multicolumn{20}{|c|}{ HEAD BREADTH. } & \\
\hline & 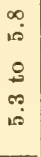 & $\begin{array}{l}\infty \\
0 \\
0 \\
\infty \\
\infty \\
0\end{array}$ & $\begin{array}{l}\infty \\
\dot{\omega} \\
\dot{0} \\
\infty \\
0\end{array}$ & $\begin{array}{l}\stackrel{8}{+} \\
\infty \\
\dot{0}\end{array}$ & 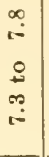 & $\begin{array}{c}\infty \\
\infty \\
0 \\
\infty \\
\infty \\
1-\end{array}$ & $\begin{array}{l}\stackrel{\rho}{+} \\
\infty \\
\infty\end{array}$ & $\begin{array}{l}\stackrel{1}{\infty} \\
\infty \\
\infty\end{array}$ & $\begin{array}{l}\infty \\
\infty \\
\infty \\
\infty \\
\infty\end{array}$ & $\begin{array}{c}\infty \\
\stackrel{0}{0} \\
\stackrel{8}{\infty} \\
\infty \\
\dot{\infty}\end{array}$ & $\begin{array}{c}\infty \\
0 \\
0 \\
\stackrel{0}{1} \\
\infty \\
0 \\
0\end{array}$ & $\begin{array}{l}-1 \\
0 \\
\infty \\
\infty \\
0\end{array}$ & 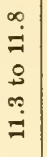 & 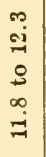 & 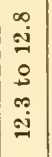 & 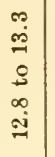 & 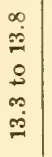 & $\begin{array}{l}\infty \\
\dot{\pi} \\
\rho \\
\infty \\
\infty \\
\infty\end{array}$ & 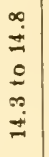 & $\begin{array}{l}\overrightarrow{0} \\
\dot{8} \\
\infty \\
\dot{z}\end{array}$ & \\
\hline & $\begin{array}{l}. . \\
\ddot{.} \\
\ddot{.} \\
\ddot{.} \\
\ddot{.} \\
\ddot{*}\end{array}$ & 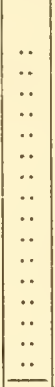 & \begin{tabular}{|c|}
$\ddot{.}$ \\
$\ddot{.}$ \\
$\ddot{.}$ \\
$\ddot{.}$ \\
$\ddot{.}$ \\
$\ddot{.}$ \\
$\ddot{.}$ \\
$\ddot{.}$ \\
$\ddot{.}$ \\
\\
\end{tabular} & 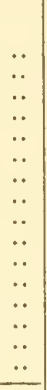 & $\begin{array}{c}1 \\
. \\
. \\
. \\
. \\
. \\
. \\
\ddot{.} \\
\ddot{.} \\
. \\
\ddot{.} \\
. . \\
\end{array}$ & 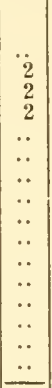 & 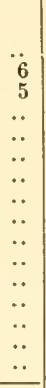 & $\begin{array}{r}\ddot{3} \\
2 \\
15 \\
2 \\
. \\
\because . \\
\because \\
\because \\
\because \\
\because \\
\because \\
\because \\
\because \\
. \\
\end{array}$ & $\begin{array}{l}\ddot{2} \\
\ddot{7} \\
22 \\
12 \\
. . \\
. \\
. \\
\ddot{.} \\
. \\
. \\
. \\
. . \\
\end{array}$ & $\begin{array}{r}.0 \\
\ddot{1} \\
15 \\
23 \\
6 \\
2 \\
. . \\
. . \\
. \\
. \\
. \\
. \\
. \\
. . \\
\end{array}$ & $\begin{array}{c}\ddot{0} \\
\ddot{y} \\
\ddot{1} \\
17 \\
23 \\
9 \\
3 \\
\ddot{1} \\
\ddot{.} \\
\ddot{.} \\
\ddot{.} \\
\end{array}$ & $\begin{array}{c}3 \\
. \\
\ddot{.} \\
\ddot{.} \\
\ddot{.} \\
\ddot{.} \\
\end{array}$ & 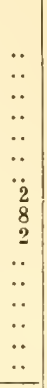 & $\begin{array}{c}. \ddot{ } \\
\ddot{.} \\
\ddot{.} \\
\ddot{0} \\
\ddot{1} \\
\ddot{1} \\
9 \\
4 \\
1 \\
1 \\
. . \\
\ddot{.} \\
. . \\
\end{array}$ & 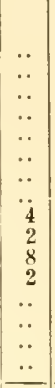 & 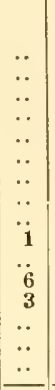 & 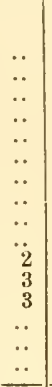 & $\begin{array}{l}\ddot{.} \\
\ddot{.} \\
\ddot{.} \\
\ddot{.}\end{array}$ & 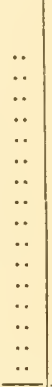 & 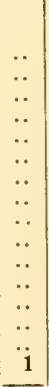 & \\
\hline Total... & 1 &.. &.. &.. & 1 & 6 & 11 & 22 & 43 & 47 & $\overline{53}$ & 34 & $\sqrt{12}$ & $\overline{16}$ & 16 & $\overline{10}$ & 8 & &.. & 1 & \\
\hline & 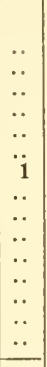 & $\begin{array}{l}. . \\
. . \\
. . \\
. . \\
. . \\
. . \\
. . \\
. \\
. \\
\ddot{.} \\
\ddot{.} \\
\end{array}$ & 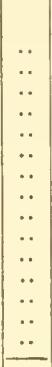 & $\begin{array}{c}. . \\
. . \\
. . \\
. . \\
. \\
. \\
. \\
. \\
. \\
. \\
. \\
. \\
. . \\
\end{array}$ & 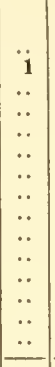 & $\begin{array}{c}2 \\
\ddot{4} \\
\because . . \\
\because . . \\
\because . . \\
\because . . \\
\because . \\
\because . \\
\because . \\
\because . \\
\end{array}$ & 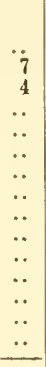 & $\begin{array}{c}\because \ddot{2} \\
6 \\
13 \\
1 \\
\because . \\
\because . \\
\because . \\
\because . \\
\because . \\
\because . \\
\because . \\
\end{array}$ & $\begin{array}{r}\ddot{1} \\
1 \\
18 \\
19 \\
3 \\
1 \\
. \\
\because \\
\because \\
\because \\
\because \\
\because \\
\because . \\
\end{array}$ & $\begin{array}{r}. \\
\ddot{2} \\
4 \\
19 \\
18 \\
4 \\
. \\
\because \\
\because \\
. \\
. \\
. \\
. \\
\end{array}$ & $\begin{array}{c}\ddot{1} \\
\ddot{i} \\
\ddot{5} \\
18 \\
22 \\
6 \\
. \\
\ddot{1} \\
. \\
\ddot{.} \\
. . \\
\end{array}$ & $\begin{array}{c}\ddot{.} \\
\ddot{1} \\
\ddot{1} \\
10 \\
17 \\
4 \\
2 \\
\ddot{.} \\
\ddot{.} \\
\ddot{.} \\
\end{array}$ & $\begin{array}{c}. . \\
. . \\
. . \\
. . \\
\ddot{2} \\
8 \\
2 \\
. . \\
. . \\
. \\
. \\
. .\end{array}$ & $\begin{array}{c}. . \\
\ddot{.} \\
\ddot{.} \\
\ddot{1} \\
4 \\
9 \\
2 \\
. \\
\ddot{.} \\
\ddot{.} \\
\end{array}$ & $\begin{array}{c}. . \\
. . \\
. . \\
. \\
. \\
. \\
\ddot{3} \\
9 \\
4 \\
. \\
. \\
. \\
. . \\
\end{array}$ & 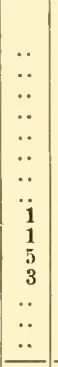 & $\begin{array}{c}. . \\
. . \\
. . \\
. . \\
. \\
. \\
\ddot{1} \\
3 \\
1 \\
3 \\
. . \\
. .\end{array}$ & 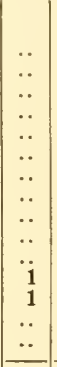 & 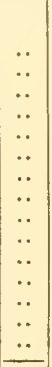 & & \\
\hline Total... & 1 & .. & .. & .. & 1 & 6 & 11 & 22 & 43 & 47 & 53 & 34 & 12 & 16 & $\overline{16}$ & $\overline{10}$ & 0 & 2 &.. & 1 & \\
\hline $\begin{array}{l}\text { LEG } \\
6.3 \text { to } \\
6.7 \text { to } \\
77.1 \text { to } \\
7.5 \text { to } \\
7.9 \text { to } \\
8.3 \text { to } \\
8.7 \text { to } \\
9.1 \text { to } \\
9.5 \text { to } \\
9.9 \text { to } \\
10.3 \text { to }\end{array}$ & 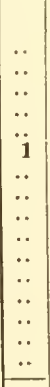 & \begin{tabular}{|l|}
$\ddot{.}$ \\
$\ddot{.}$ \\
$\ddot{.}$ \\
$\ddot{.}$ \\
$\ddot{.}$ \\
$\ddot{.}$ \\
$\ddot{.}$ \\
$\ddot{.}$ \\
$\ddot{.}$ \\
\end{tabular} & $\begin{array}{l}\ddot{.} \\
\ddot{.} \\
\ddot{.} \\
\ddot{.} \\
\ddot{.} \\
\ddot{.} \\
\ddot{.} \\
\ddot{.} \\
\ddot{.} \\
\ddot{.} \\
.\end{array}$ & $\begin{array}{c}.0 \\
. \\
\ddot{.} \\
\ddot{.} \\
. \\
\ddot{.} \\
\ddot{.} \\
\ddot{.} \\
\ddot{.} \\
\ddot{.} \\
. \\
. .\end{array}$ & 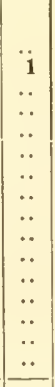 & $\begin{array}{c}1 \\
1 \\
3 \\
1 \\
. . \\
. . \\
. . \\
. . \\
. . \\
. . \\
. \\
. \\
. . \\
. . \\
\end{array}$ & $\begin{array}{c}\ddot{5} \\
6 \\
. . \\
\because . \\
\because . \\
\because . \\
\because . \\
\because . \\
\because . \\
\because . \\
.\end{array}$ & 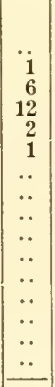 & $\begin{array}{r}1 \\
1 \\
3 \\
10 \\
19 \\
7 \\
3 \\
\because . \\
\because . \\
\because . \\
\because . \\
\because . \\
. . \\
. .\end{array}$ & $\begin{array}{c}\because \\
\ddot{2} \\
12 \\
26 \\
7 \\
\ddot{.} \\
\because \\
\because \\
\because \\
\because \\
\because \\
.\end{array}$ & $\begin{array}{c}\ddot{.} \\
\ddot{0} \\
\ddot{3} \\
9 \\
23 \\
16 \\
1 \\
\ddot{1} \\
\ddot{0} \\
\ddot{.} \\
\ddot{.} \\
\end{array}$ & 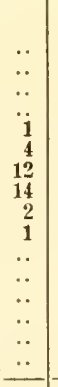 & $\begin{array}{c}. . \\
. . \\
. \\
. . \\
. . \\
. \\
\ddot{7} \\
5 \\
. . \\
. . \\
. . \\
. . \\
. . \\
\end{array}$ & 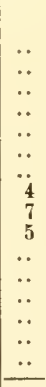 & 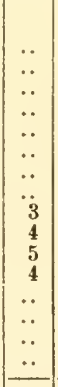 & $\begin{array}{c}\because . \\
\because \\
\because \\
\because \\
\because \\
\ddot{.} \\
\ddot{1} \\
2 \\
5 \\
1 \\
1 \\
\because \\
.\end{array}$ & $\begin{array}{c}. . \\
\ddot{.} \\
\ddot{.} \\
\ddot{.} \\
\ddot{.} \\
\ddot{1} \\
1 \\
3 \\
1 \\
2 \\
. . \\
\end{array}$ & 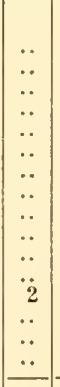 & $\begin{array}{l}\ddot{.} \\
\ddot{.} \\
\ddot{.} \\
\ddot{.} \\
\ddot{.} \\
\ddot{.} \\
\ddot{.} \\
\ddot{.} \\
\ddot{.} \\
\ddot{.} \\
\ddot{.} \\
\end{array}$ & 1 & \\
\hline Total... & 1 & .. & & $\cdot \cdots$ & 1 & 6 & 11 & 22 & 43 & 47 & 53 & 34 & 12 & 16 & 16 & 10 & 8 & 2 & & 1 & \\
\hline
\end{tabular}


TABLES OF MEASUREMENTS.

TABLE 23.-Continued.

\begin{tabular}{|c|c|c|c|c|c|c|c|c|c|c|c|c|c|c|c|c|c|c|c|c|c|}
\hline \multirow[b]{2}{*}{$\begin{array}{c}\text { LENGTH } \\
\text { OF } \\
\text { CARPOPO- } \\
\text { DITE. }\end{array}$} & \multicolumn{20}{|c|}{ HEAD BREADTh. } & \\
\hline & 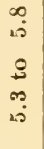 & 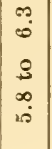 & 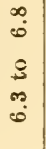 & $\begin{array}{l}\stackrel{3}{3} \\
\infty \\
\infty \\
\stackrel{0}{0}\end{array}$ & $\begin{array}{l}\infty \\
\stackrel{\infty}{-} \\
\stackrel{+}{\circ} \\
\stackrel{\infty}{r}\end{array}$ & $\begin{array}{l}\stackrel{9}{\infty} \\
\infty \\
\stackrel{2}{\circ}\end{array}$ & $\begin{array}{l}\stackrel{0}{\infty} \\
\infty \\
\infty\end{array}$ & $\begin{array}{l}9 \\
\infty \\
\infty \\
\infty\end{array}$ & $\begin{array}{l}\infty \\
\infty \\
\infty \\
\infty \\
\infty \\
\infty\end{array}$ & 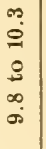 & $\begin{array}{l}\infty \\
\stackrel{0}{0} \\
\stackrel{+}{0} \\
0 \\
\stackrel{0}{0}\end{array}$ & 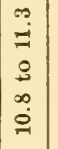 & 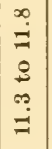 & 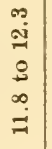 & 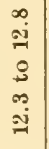 & 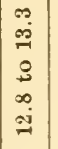 & 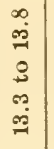 & 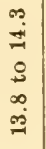 & 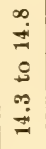 & 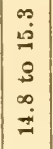 & تूँّ \\
\hline $\begin{array}{l}5.1 \\
5.5 \\
5.9 \\
6.3 \\
6.7 \\
7.1 \\
7.5 \\
7.9 \\
8.3 \\
8.7 \\
9.1 \\
9.5 \\
9.9 \\
10.3 \\
10.7 \\
11.1 \\
11.5\end{array}$ & $\begin{array}{c}. \ddot{ } \\
\ddot{.} \\
\ddot{.} \\
\ddot{1} \\
\ddot{.} \\
\ddot{.} \\
\ddot{.} \\
\ddot{.} \\
\ddot{.} \\
\end{array}$ & 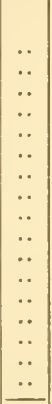 & 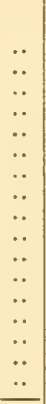 & 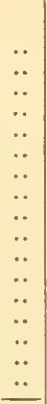 & 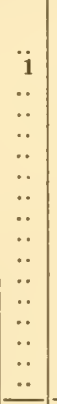 & $\begin{array}{c}1 \\
4 \\
1 \\
. \\
. \\
. \\
. \\
. \\
. \\
. \\
. \\
\because . \\
. \\
. \\
. . \\
\end{array}$ & $\begin{array}{c}1 \\
1 \\
5 \\
4 \\
. \\
. \\
\because \\
\because \\
\because \\
\because \\
\because \\
\because \\
\because \\
\because . \\
. . \\
\end{array}$ & 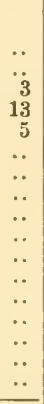 & $\begin{array}{c}\ddot{2} \\
\ddot{1} \\
20 \\
17 \\
3 \\
\because \\
\because \\
\because \\
\because \\
\because \\
\because \\
\because \\
\because \\
.\end{array}$ & $\begin{array}{c}14 \\
21 \\
11 \\
1 \\
. . \\
. \\
. \\
. \\
. \\
. \\
. \\
. .\end{array}$ & 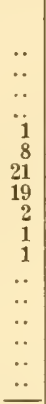 & 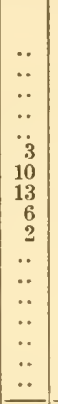 & 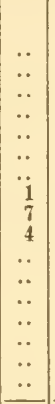 & 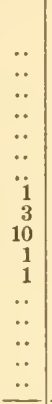 & $\begin{array}{c}. . \\
. . \\
. . \\
. . \\
. \\
\ddot{2} \\
4 \\
5 \\
4 \\
1 \\
. \\
\ddot{.} \\
\end{array}$ & 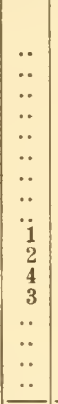 & $\begin{array}{l}. . \\
. . \\
. . \\
. . \\
. . \\
. . \\
\ddot{2} \\
\ddot{2} \\
3 \\
2 \\
2 \\
. . \\
. . \\
\end{array}$ & 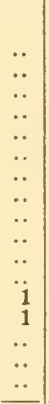 & & 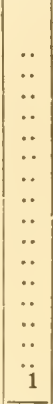 & 1 \\
\hline Total... & 1 & .. & .. & .. & 1 & 6 & 11 & 22 & 43 & 47 & 53 & 34 & 12 & 16 & 16 & 10 & 8 & & & 1 & 283 \\
\hline 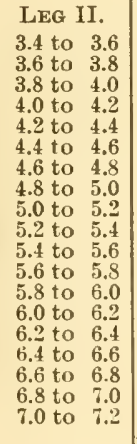 & 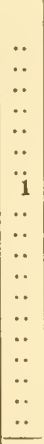 & $\begin{array}{l}. . \\
. . \\
. . \\
. . \\
. . \\
. . \\
. \\
. \\
. \\
. \\
. \\
. \\
. \\
. \\
. .\end{array}$ & $\begin{array}{l}. . \\
. \\
. . \\
. . \\
. \\
. \\
. \\
. \\
. \\
. \\
. \\
. \\
. \\
. \\
. \\
. \\
\end{array}$ & \begin{tabular}{l|}
.. \\
.. \\
.. \\
.. \\
.. \\
.. \\
. \\
.. \\
.. \\
. \\
. \\
. \\
. \\
.. \\
\end{tabular} & 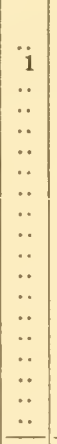 & $\begin{array}{c}2 \\
2 \\
1 \\
1 \\
. . \\
\because \\
\because \\
\because \\
\because \\
\because \\
\because \\
\because \\
\because \\
\because \\
\because \\
\because \\
\because \\
. \\
\end{array}$ & 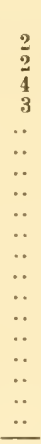 & 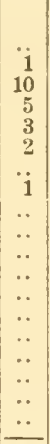 & $\begin{array}{r}1 \\
5 \\
5 \\
17 \\
10 \\
5 \\
. . \\
. \\
. \\
. \\
. \\
. \\
. \\
. \\
. \\
. \\
.\end{array}$ & 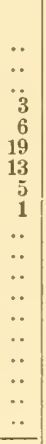 & $\begin{array}{r}. . \\
\ddot{.} \\
\ddot{4} \\
5 \\
11 \\
17 \\
11 \\
4 \\
. \\
. \\
. \\
. \\
. \\
. \\
\ddot{.} \\
\ddot{1}\end{array}$ & $\begin{array}{r}. . \\
\ddot{.} \\
\ddot{1} \\
1 \\
7 \\
13 \\
9 \\
2 \\
. . \\
\ddot{.} \\
. \\
\ddot{1} \\
. . \\
. . \\
\end{array}$ & \begin{tabular}{c|}
.. \\
. \\
. \\
. \\
$\ddot{1}$ \\
3 \\
4 \\
2 \\
1 \\
1 \\
. \\
$\ddot{.}$ \\
. \\
. \\
..
\end{tabular} & $\begin{array}{c}\ddot{.} \\
\ddot{.} \\
\ddot{.} \\
\ddot{.} \\
\ddot{2} \\
2 \\
11 \\
1 \\
. \\
\ddot{.} \\
\ddot{.} \\
\ddot{.} \\
. \\
\end{array}$ & $\begin{array}{l}. . \\
. . \\
. . \\
. . \\
. . \\
. \\
\ddot{i} \\
.2 \\
6 \\
2 \\
4 \\
1 \\
. \\
. \\
. . \\
. .\end{array}$ & \begin{tabular}{c|}
$\ddot{.}$ \\
$\ddot{.}$ \\
$\ddot{.}$ \\
$\ddot{.}$ \\
$\ddot{.}$ \\
$\ddot{1}$ \\
2 \\
1 \\
2 \\
2 \\
2 \\
$\ddot{.}$ \\
$\ddot{.}$ \\
. \\
\end{tabular} & $\begin{array}{c}. \ddot{ } \\
\ddot{.} \\
. \\
\ddot{.} \\
\ddot{.} \\
\ddot{.} \\
\ddot{1} \\
3 \\
\ddot{3} \\
\ddot{i} \\
. \\
. . \\
\end{array}$ & 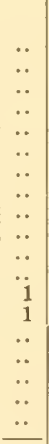 & & 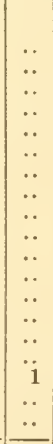 & \\
\hline al... & 1 & .. & .. & .. & 1 & 6 & 11 & 22 & 43 & 47 & 53 & 34 & 12 & 16 & 16 & 10 & 8 & & .. & 1 & 28 \\
\hline $\begin{array}{l}\text { LEG III. } \\
4.2 \text { to } 4.5 \\
4.5 \text { to } 4.8 \\
4.8 \text { to } 3.1 \\
5.1 \text { to } 5.4 \\
5.4 \text { to } 5.7 \\
5.7 \text { to } 6.0 \\
6.0 \text { to } 6.3 \\
6.3 \text { to } 6.6 \\
6.6 \text { to } 6.9 \\
6.9 \text { to } 7.2 \\
7.2 \text { to } 7.5 \\
7.5 \text { to } 7.8 \\
7.8 \text { to } 8.1 \\
8.1 \text { to } 8.4 \\
8.4 \text { to } 8.7 \\
8.7 \text { to } 9.0 \\
9.0 \text { to } 9.3 \\
9.3 \text { to } 9.6 \\
9.6 \text { to } 9.9\end{array}$ & $\begin{array}{c}. . \\
\ddot{.} \\
\ddot{.} \\
\ddot{\mathbf{i}} \\
. \\
\ddot{.} \\
\ddot{.} \\
\ddot{.}\end{array}$ & \begin{tabular}{|l|}
$\ddot{.}$ \\
$\ddot{.}$ \\
$\ddot{.}$ \\
$\ddot{.}$ \\
$\ddot{.}$ \\
$\ddot{.}$ \\
$\ddot{.}$ \\
$\ddot{.}$ \\
$\ddot{.}$ \\
$\ddot{.}$ \\
$\ddot{.}$ \\
\end{tabular} & $\begin{array}{l}. . \\
. . \\
. . \\
. . \\
. . \\
. . \\
. \\
\ddot{.} \\
\ddot{.} \\
\ddot{.} \\
\ddot{.} \\
.\end{array}$ & $\begin{array}{l}. . \\
. . \\
. . \\
. . \\
. \\
. \\
. . \\
. . \\
\ddot{.} \\
. \\
\ddot{.} \\
. \\
. \\
. . \\
\end{array}$ & 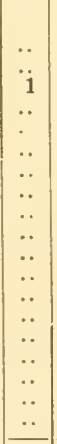 & 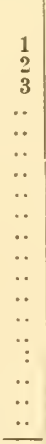 & $\begin{array}{l}1 \\
2 \\
5 \\
2 \\
1 \\
. . \\
. . \\
. . \\
. . \\
. \\
. \\
. \\
. \\
. \\
.\end{array}$ & 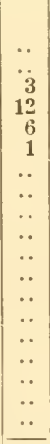 & $\begin{array}{r}\because 1 \\
1 \\
9 \\
19 \\
9 \\
3 \\
. \\
. . \\
. \\
. \\
. \\
. \\
. \\
. \\
. \\
. .\end{array}$ & $\begin{array}{r}. . \\
11 \\
1 \\
10 \\
19 \\
13 \\
1 \\
1 \\
. \\
\ddot{1} \\
. \\
. \\
. \\
. \\
. \\
.\end{array}$ & 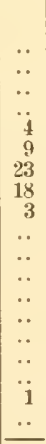 & 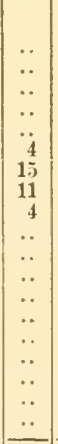 & $\begin{array}{l}. . \\
. \\
\ddot{i} \\
. \\
\ddot{2} \\
4 \\
3 \\
1 \\
. \\
. \\
. \\
. \\
. \\
. \\
. \\
. \\
\mathrm{i}\end{array}$ & 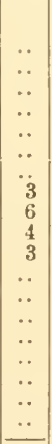 & 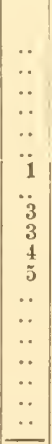 & 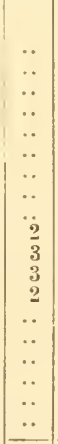 & 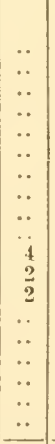 & $\begin{array}{l} \\
\vdots\end{array}$ & $\begin{array}{l}\because \because \\
\because \because \\
\because \because \\
\because . \\
\because \\
\because \\
\because \\
\because \\
\because \\
\because \\
\because\end{array}$ & 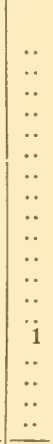 & \\
\hline Total... & 1 & . & .. &.. & 1 & 6 & 11 & 22 & 43 & 47 & 53 & 34 & 12 & 16 & 16 & 10 & 8 & -1 & .. & 1 & 28 \\
\hline
\end{tabular}


TABLE 23.-Continued.

\begin{tabular}{|c|c|c|c|c|c|c|c|c|c|c|c|c|c|c|c|c|c|c|c|c|c|}
\hline \multirow[b]{2}{*}{$\begin{array}{l}\text { LENGTH } \\
\text { OF } \\
\text { PROPO- } \\
\text { DITE. }\end{array}$} & \multicolumn{20}{|c|}{ HEAD Breadth. } & \\
\hline & 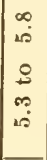 & 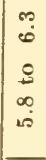 & 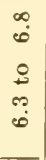 & $\begin{array}{l}\infty \\
i- \\
\infty \\
\infty \\
0\end{array}$ & 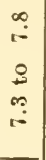 & $\mid \begin{array}{c}\infty \\
\infty \\
\infty \\
\infty \\
\infty \\
\vdots\end{array}$ & $\begin{array}{l}\infty \\
\infty\end{array}$ & $\begin{array}{l}\infty \\
\infty \\
\dot{0} \\
\infty \\
\infty\end{array}$ & $\mid \begin{array}{c}\infty \\
\infty \\
0 \\
0 \\
\tilde{\sigma} \\
\infty \\
0\end{array}$ & $\begin{array}{l}\mathcal{8} \\
\infty \\
\infty \\
0\end{array}$ & $\begin{array}{l}\infty \\
\stackrel{\leftrightarrow}{0} \\
\stackrel{0}{0} \\
ٌ \\
\stackrel{0}{0}\end{array}$ & $\begin{array}{l}\cong \\
\Xi \\
\rho \\
\infty \\
\stackrel{0}{0} \\
\ddots\end{array}$ & $\begin{array}{l}\infty \\
\beth \\
\stackrel{1}{\perp} \\
\infty \\
=\end{array}$ & 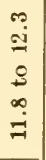 & 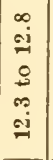 & 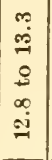 & 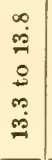 & 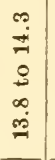 & 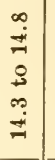 & 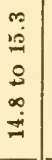 & \\
\hline $\begin{array}{c}\text { LEG I. } \\
12.1 \text { to } 13.1 \\
13.1 \text { to } 14.1 \\
14.1 \text { to } 15.1 \\
15.1 \text { to } 16.1 \\
16.1 \text { to } 17.1 \\
17.1 \text { to } 18.1 \\
18.1 \text { to } 19.1 \\
19.1 \text { to } 20.1 \\
20.1 \text { to } 21.1 \\
21.1 \text { to } 22.1 \\
22.1 \text { to } 23.1 \\
23.1 \text { to } 24.1 \\
24.1 \text { to } 25.1 \\
25.1 \text { to } 26.1 \\
26.1 \text { to } 26.1 \\
27.1 \text { to } 28.1 \\
28.1 \text { to } 29.1 \\
29.1 \text { to } 30.1 \\
30.1 \text { to } 31.1 \\
31.1 \text { to } 32.1 \\
32.1 \text { to } 33.1 \\
33.1 \text { to } 34.1\end{array}$ & 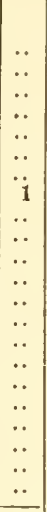 & 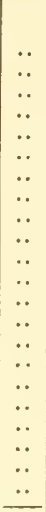 & $\begin{array}{l}\ddot{.} \\
\ddot{.} \\
\ddot{.} \\
\ddot{.} \\
\ddot{.} \\
\ddot{.} \\
\ddot{.} \\
\ddot{~} \\
\ddot{.} \\
\ddot{~} \\
\ddot{.}\end{array}$ & 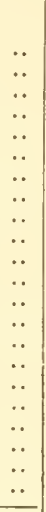 & $\begin{array}{l}.1 \\
. . \\
. . \\
. . \\
. . \\
. . \\
. \\
. . \\
. \\
. . \\
. \\
. \\
. \\
. \\
. \\
. . \\
\end{array}$ & $\begin{array}{c}\ddot{1} \\
2 \\
3 \\
. . \\
. \\
. . \\
. \\
. \\
. \\
. \\
. \\
. \\
. \\
. \\
. \\
. \\
. \\
. \\
. \\
. . \\
\end{array}$ & $\begin{array}{l}\ddot{i} \\
4 \\
5 \\
1 \\
. . \\
\because . \\
\ddot{.} \\
\because . \\
. . \\
. .\end{array}$ & $\begin{array}{l}\ddot{.} \\
\ddot{5} \\
12 \\
3 \\
1 \\
1 \\
. . \\
\ddot{.} \\
\ddot{.} \\
\ddot{.} \\
\ddot{.} \\
\ddot{.} \\
\ddot{.} \\
\ddot{.} \\
\end{array}$ & $\begin{array}{c}1 \\
1 \\
. \\
\ddot{4} \\
12 \\
15 \\
10 \\
. \\
. \\
. \\
. \\
. \\
. \\
. \\
. \\
. \\
. \\
. \\
. \\
. . \\
\end{array}$ & $\begin{array}{r}\because . \\
\because . \\
\ddot{2} \\
8 \\
13 \\
12 \\
9 \\
3 \\
. . \\
\because . \\
\because \\
\because . \\
\because . \\
\because . \\
. \\
. \\
. . \\
\end{array}$ & 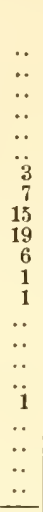 & \begin{tabular}{c|}
$\ddot{.}$ \\
$\ddot{.}$ \\
$\ddot{1}$ \\
2 \\
2 \\
6 \\
6 \\
6 \\
9 \\
3 \\
1 \\
. \\
$\ddot{.}$ \\
$\ddot{.}$ \\
. \\
. \\
. \\
.. \\
\end{tabular} & $\begin{array}{l}. . \\
. \\
. . \\
. . \\
. \\
\ddot{1} \\
1 \\
3 \\
5 \\
1 \\
1 \\
. \\
. \\
. \\
. \\
. \\
. \\
. . \\
\end{array}$ & $\begin{array}{l}. . \\
\ddot{.} \\
\ddot{.} \\
\ddot{.} \\
\ddot{.} \\
\ddot{.} \\
\ddot{2} \\
6 \\
6 \\
2 \\
. \\
. \\
. \\
. \\
. \\
. . \\
\end{array}$ & $\begin{array}{l}. . \\
. \\
. \\
. \\
. . \\
. \\
. \\
\ddot{1} \\
1 \\
3 \\
2 \\
5 \\
3 \\
1 \\
. \\
. \\
. \\
. . \\
\end{array}$ & 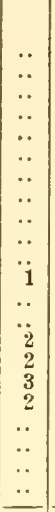 & $\begin{array}{l}. . \\
. . \\
\because . \\
. . \\
. . \\
. . \\
\because . \\
\because . \\
. . \\
\ddot{2} \\
1 \\
2 \\
1 \\
2 \\
. . \\
. . \\
\end{array}$ & 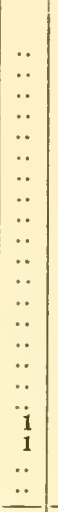 & 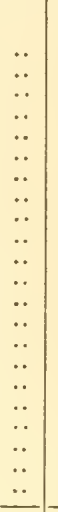 & 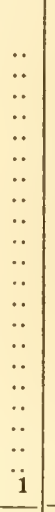 & \\
\hline Total... & 1 & .. & .. &.. & 1 & 6 & 11 & 22 & 43 & 47 & $\overline{53}$ & 34 & $\overline{12}$ & 16 & $\overline{16}$ & $\overline{10}$ & $\overline{8}$ & 2 &.. & 1 & 28 \\
\hline $\begin{array}{l}\text { LEG II. } \\
4.9 \text { to } 5.2 \\
5.2 \text { to } 5.5 \\
5.5 \text { to } 5.8 \\
5.8 \text { to } 6.1 \\
6.1 \text { to } 6.4 \\
6.4 \text { to } 6.7 \\
6.7 \text { to } 7.0 \\
7.0 \text { to } 7.3 \\
77.3 \text { to } 7.6 \\
7.6 \text { to } 7.9 \\
7.9 \text { to } 8.2 \\
8.2 \text { to } 8.5 \\
8.5 \text { to } 8.8 \\
8.8 \text { to } 9.1 \\
9.1 \text { to } 9.4 \\
9.4 \text { to } 9.7 \\
9.7\end{array}$ & $\begin{array}{l}\ddot{.} \\
\ddot{.} \\
\ddot{1} \\
\ddot{.} \\
\ddot{.} \\
\ddot{.} \\
\ddot{.} \\
\ddot{.} \\
\ddot{.}\end{array}$ & 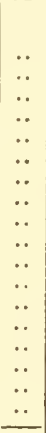 & $\begin{array}{l}. . \\
\ddot{.} \\
\ddot{.} \\
\ddot{.} \\
\ddot{.} \\
\ddot{.} \\
\ddot{.} \\
\ddot{.} \\
\ddot{.} \\
\ddot{.} \\
\end{array}$ & 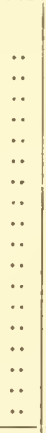 & 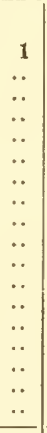 & $\begin{array}{l}\ddot{2} \\
3 \\
1 \\
. \\
\ddot{.} \\
\ddot{.} \\
\ddot{.} \\
. \\
. \\
. \\
. \\
\ddot{.} \\
\ddot{.} \\
. \\
\end{array}$ & 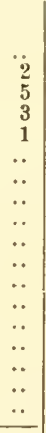 & $\begin{array}{c}\ddot{2} \\
1 \\
8 \\
9 \\
2 \\
. \\
\ddot{.} \\
\ddot{.} \\
\ddot{.} \\
\ddot{.} \\
\ddot{.} \\
\ddot{.} \\
\ddot{.} \\
\end{array}$ & $\begin{array}{c}\ddot{2} \\
1 \\
10 \\
19 \\
11 \\
. \\
\ddot{.} \\
\ddot{.} \\
. \\
\ddot{.} \\
. \\
\ddot{.} \\
. . \\
\end{array}$ & $\begin{array}{c}. . \\
\ddot{.} \\
\ddot{3} \\
20 \\
17 \\
6 \\
\ddot{1} \\
. \\
. \\
. \\
. \\
. \\
. \\
. . \\
\end{array}$ & $\begin{array}{r}\because . \\
\ddot{1} \\
1 \\
3 \\
12 \\
22 \\
12 \\
1 \\
1 \\
\because \\
\ddot{.} \\
\ddot{.} \\
\ddot{.} \\
\end{array}$ & \begin{tabular}{r|}
$\ddot{.}$ \\
$\ddot{.}$ \\
$\ddot{.}$ \\
$\ddot{5}$ \\
13 \\
9 \\
6 \\
1 \\
. \\
. \\
. \\
. \\
. \\
. \\
.. \\
\end{tabular} & $\begin{array}{l}. . \\
. \\
. \\
. \\
. \\
. \\
\ddot{5} \\
6 \\
1 \\
. \\
\ddot{.} \\
\ddot{.} \\
. \\
. . \\
\end{array}$ & $\begin{array}{l}. . \\
\ddot{.} \\
\ddot{.} \\
\ddot{.} \\
\ddot{4} \\
6 \\
4 \\
. \\
. \\
\ddot{.} \\
. \\
. . \\
\end{array}$ & $\begin{array}{l}. . \\
\ddot{.} \\
\ddot{.} \\
. \\
. \\
\ddot{2} \\
\ddot{2} \\
3 \\
5 \\
1 \\
. \\
. \\
. \\
. \\
\end{array}$ & 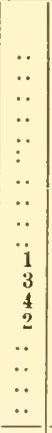 & $\begin{array}{l}. . \\
. . \\
\ddot{.} \\
\ddot{.} \\
\ddot{.} \\
\ddot{1} \\
2 \\
2 \\
1 \\
1 \\
. \\
. . \\
\end{array}$ & $\begin{array}{l}\ddot{.} \\
\ddot{.} \\
\ddot{.} \\
\ddot{.} \\
. \\
. \\
. \\
\ddot{.} \\
\ddot{1} \\
. \\
. \\
. \\
.\end{array}$ & $\begin{array}{l}\ddot{.} \\
\ddot{.} \\
\ddot{.} \\
\ddot{.} \\
\ddot{.} \\
\ddot{.} \\
\ddot{.} \\
\ddot{~} \\
\ddot{.} \\
\ddot{.}\end{array}$ & $\begin{array}{l}\ddot{0} \\
\ddot{.} \\
\ddot{.} \\
\ddot{0} \\
\ddot{0} \\
\ddot{0} \\
\ddot{0} \\
\ddot{~} \\
\ddot{1}\end{array}$ & $\begin{array}{l}1 \\
1 \\
2 \\
4 \\
4 \\
4 \\
3 \\
2 \\
1 \\
1 \\
1\end{array}$ \\
\hline Total... & 1 & .. & .. & .. & 1 & 6 & 11 & 22 & 43 & 47 & 53 & $\overline{34}$ & $\overline{12}$ & 16 & $\overline{16}$ & $\overline{10}$ & 8 & 2 & & 1 & 28 \\
\hline $\begin{array}{l}\text { III. } \\
7.0 \\
7.4 \\
7.8 \\
8.2 \\
8.6 \\
9.0 \\
9.4 \\
9.8 \\
10.2 \\
10.6\end{array}$ & $\begin{array}{l}\ddot{.} \\
. \\
. .\end{array}$ & & 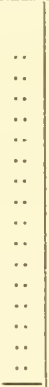 & 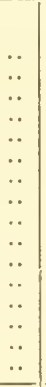 & $\begin{array}{c}\mathbf{1} \\
. . \\
. . \\
. . \\
. . \\
. . \\
. \\
. \\
. . \\
. \\
. .\end{array}$ & 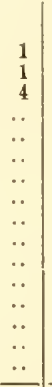 & 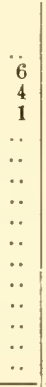 & 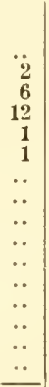 & $\begin{array}{l}2 \\
2 \\
12 \\
16 \\
11 \\
. . \\
. . \\
. . \\
. . \\
. \\
. \\
. . \\
.\end{array}$ & $\begin{array}{c}. . \\
\ddot{3} \\
14 \\
22 \\
1 \\
1 \\
. \\
. \\
. \\
. \\
. \\
. \\
. \\
\end{array}$ & 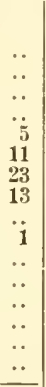 & 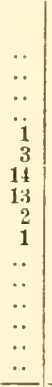 & 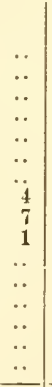 & 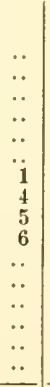 & $\begin{array}{l}. . \\
\because . . \\
. . . \\
. . \\
\ddot{3} \\
2 \\
9 \\
1 \\
1 \\
. . \\
. . \\
\end{array}$ & 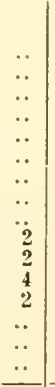 & 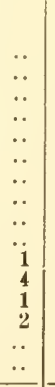 & 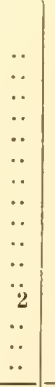 & 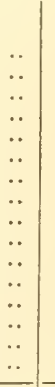 & 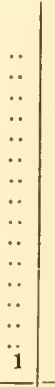 & $\begin{array}{r}1 \\
12 \\
16 \\
28 \\
38 \\
48 \\
45 \\
35 \\
17 \\
13 \\
12 \\
9\end{array}$ \\
\hline Total... & 1 & & .. & .. & 1 & 6 & 11 & 22 & 43 & 47 & 53 & $3 t$ & 12 & 16 & 16 & 10 & 8 & 2 & & 12 & 283 \\
\hline
\end{tabular}


TABLES OF MEASUREMENTS

TABLE 24.

\begin{tabular}{|c|c|c|c|c|c|c|c|c|c|c|c|c|c|c|c|c|c|}
\hline \multirow[b]{2}{*}{ LENGTH OF MERIPODITE. } & \multicolumn{17}{|c|}{ Length of Meripodite, Leg I. } \\
\hline & $\begin{array}{l}\overrightarrow{1} \\
- \\
0 \\
0 \\
0 \\
0\end{array}$ & 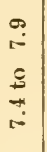 & $\begin{array}{l}\overrightarrow{+} \\
\infty \\
\dot{0} \\
\dot{0} \\
\dot{0}\end{array}$ & $\begin{array}{l}0 \\
\infty \\
0 \\
\$ \\
+ \\
\infty\end{array}$ & $\begin{array}{l}\overrightarrow{0} \\
0 \\
\$ \\
0 \\
\infty \\
\infty\end{array}$ & $\begin{array}{l}\$ \\
0 \\
\$ \\
\vdots \\
0\end{array}$ & $\begin{array}{l}\overrightarrow{0} \\
\stackrel{0}{0} \\
\stackrel{0}{0} \\
0 \\
0\end{array}$ & $\begin{array}{l}\stackrel{0}{0} \\
0 \\
\stackrel{0}{8} \\
\stackrel{0}{0} \\
\stackrel{0}{0}\end{array}$ & 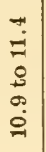 & 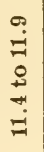 & 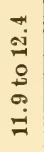 & 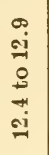 & $\begin{array}{l}\ddot{1} \\
\stackrel{3}{9} \\
0 \\
0 \\
0 \\
a j\end{array}$ & 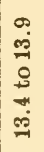 & 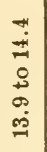 & $\begin{array}{l}0 \\
\\
\\
\\
\\
-\end{array}$ & [ٓ \\
\hline 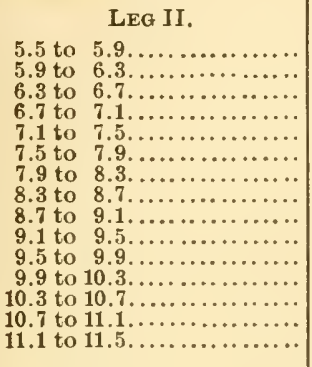 & $\begin{array}{l}\ddot{1} \\
\ddot{.} \\
\ddot{.} \\
\ddot{.} \\
\ddot{*} \\
\ddot{*} \\
\ddot{*} \\
\ddot{.} \\
\ddot{.}\end{array}$ & $\begin{array}{l}2 \\
7 \\
4 \\
\because . \\
\because . \\
\because . \\
\because . \\
\because . \\
\because . \\
\because . \\
\because . \\
\because . \\
\because . \\
. \\
\end{array}$ & 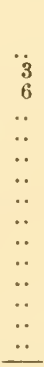 & 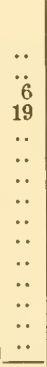 & $\begin{array}{r}\because . \\
\because \\
12 \\
24 \\
3 \\
\cdots \\
\therefore \\
\therefore \\
\because . \\
\therefore \\
\therefore \\
\therefore \\
\therefore\end{array}$ & $\begin{array}{r}\because \\
\dddot{1} \\
4 \\
18 \\
26 \\
5 \\
1 \\
\because . \\
\because . \\
\because . \\
\because . \\
\because . \\
\cdots\end{array}$ & $\begin{array}{r}\ddot{.} \\
\ddot{1} \\
\ddot{3} \\
17 \\
23 \\
1 \\
1 \\
\because . \\
\because . \\
\because . \\
\because \\
.\end{array}$ & 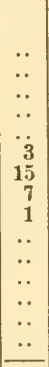 & $\begin{array}{r}. . \\
. . \\
. . \\
. . \\
\ddot{.} \\
\ddot{5} \\
11 \\
10 \\
1 \\
. . \\
\ddot{.} \\
\ddot{.} \\
\ddot{.} \\
\end{array}$ & $\begin{array}{c}. . \\
. . \\
\ddot{.} \\
\ddot{.} \\
\ddot{.} \\
\ddot{.} \\
\ddot{2} \\
5 \\
2 \\
. \\
\ddot{.} \\
\ddot{.} \\
\ddot{.} \\
\end{array}$ & $\begin{array}{l}\ddot{.} \\
\ddot{.} \\
\ddot{.} \\
\ddot{.} \\
\ddot{.} \\
\ddot{.} \\
\ddot{7} \\
\ddot{7} \\
\ddot{5} \\
\ddot{.} \\
\ddot{.} \\
.\end{array}$ & 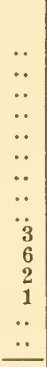 & $\begin{array}{c}. . \\
\because . \\
\because . \\
\because . \\
\because . \\
\because . \\
\because . \\
. . \\
\ddot{2} \\
3 \\
3 \\
. . \\
. . \\
\end{array}$ & 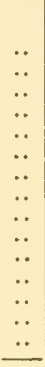 & $\begin{array}{c}. \\
\because \\
\because \\
\because \\
\because \\
\because \\
\because \\
\because \\
\because \\
\because \\
\because \\
\because \\
\end{array}$ & $\begin{array}{c}\because \\
\because \\
\therefore \\
\therefore \\
\therefore \\
\therefore \\
\therefore \\
\therefore \\
\therefore \\
\because \\
\because \\
\ddot{1} \\
\end{array}$ & \begin{tabular}{|r}
2 \\
11 \\
18 \\
35 \\
45 \\
49 \\
48 \\
22 \\
17 \\
13 \\
13 \\
5 \\
4 \\
7 \\
1
\end{tabular} \\
\hline Total................ & 1 & 13 & 9 & 25 & 39 & 55 & 46 & 26 & 27 & 9 & 12 & 12 & 8 & .. & $\cdots$ & 1 & 283 \\
\hline 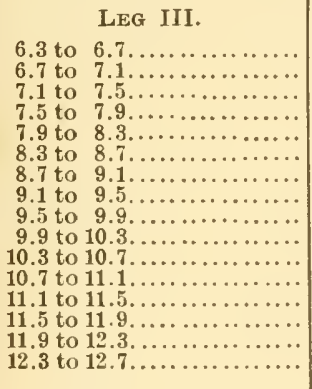 & 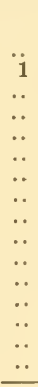 & $\begin{array}{c}1 \\
7 \\
5 \\
. . \\
. . \\
. . \\
. . \\
. . \\
. . \\
. \\
. \\
. \\
. \\
\because . \\
.\end{array}$ & 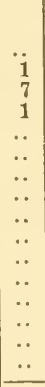 & 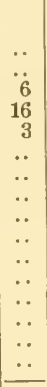 & $\begin{array}{c}. . \\
\because . \\
\ddot{7} \\
18 \\
14 \\
. . \\
\because \\
\because \\
\because \\
\because \\
\because \\
\because \\
\because \\
\end{array}$ & $\begin{array}{r}. . \\
\ddot{.} \\
\ddot{1} \\
14 \\
22 \\
16 \\
2 \\
. . \\
. . \\
. . \\
. . \\
. \\
. \\
. \\
\end{array}$ & $\begin{array}{c}. . \\
. . \\
. \\
\ddot{2} \\
12 \\
21 \\
11 \\
. \\
. \\
\because . \\
. . \\
. . \\
. \\
.\end{array}$ & 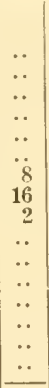 & 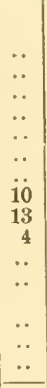 & $\begin{array}{c}. . \\
. \\
. . \\
. . \\
\because . \\
. . \\
\because . \\
2 \\
3 \\
3 \\
1 \\
. . \\
. . \\
\because . \\
. . \\
\end{array}$ & 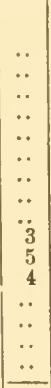 & $\begin{array}{c}. . \\
\ddot{.} \\
. . \\
. . \\
\ddot{.} \\
\ddot{.} \\
\ddot{2} \\
3 \\
6 \\
1 \\
. . \\
. . \\
\end{array}$ & $\begin{array}{c}. . \\
. . \\
. . \\
. . \\
\because . \\
\ddot{.} \\
. . \\
. . \\
\ddot{2} \\
3 \\
3 \\
. \\
. . \\
\end{array}$ & $\begin{array}{c}. . \\
. . \\
. . \\
. . \\
. . \\
. . \\
\ddot{.} \\
\ddot{.} \\
. \\
\ddot{.} \\
\ddot{.} \\
\end{array}$ & 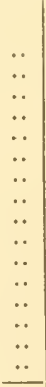 & 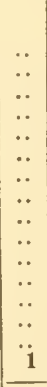 & \begin{tabular}{|r}
$\mathbf{1}$ \\
$\mathbf{9}$ \\
$\mathbf{1 8}$ \\
$\mathbf{2 5}$ \\
$\mathbf{3 7}$ \\
$\mathbf{4 8}$ \\
$\mathbf{4 5}$ \\
$\mathbf{4 1}$ \\
18 \\
12 \\
9 \\
12 \\
4 \\
$\mathbf{3}$ \\
$\mathrm{i}$ \\
\end{tabular} \\
\hline Total................ & 1 & 13 & 9 & 25 & 39 & 55 & 46 & 26 & 27 & 9 & 12 & 12 & 8 & .. & .. & 1 & 283 \\
\hline
\end{tabular}


TABLE 24.-Continued.

\begin{tabular}{|c|c|c|c|c|c|c|c|c|c|c|c|c|c|c|c|c|c|}
\hline \multirow[b]{2}{*}{ Length of Carpopodite. } & \multicolumn{17}{|c|}{ Length of Meripodite, Leg I. } \\
\hline & $\begin{array}{l}\overrightarrow{0} \\
\stackrel{0}{0} \\
0 \\
0 \\
0 \\
0 \\
0\end{array}$ & 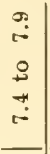 & $\begin{array}{l}\overrightarrow{0} \\
\infty \\
\stackrel{0}{0} \\
\stackrel{0}{0}\end{array}$ & 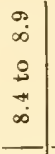 & $\begin{array}{l}\overrightarrow{0} \\
\dot{0} \\
\dot{\$} \\
\dot{\infty} \\
\dot{\infty}\end{array}$ & $\begin{array}{l}\dot{\rho} \\
\dot{0} \\
\dot{8} \\
\vec{\sigma} \\
\dot{\sigma}\end{array}$ & 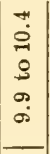 & 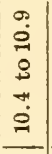 & 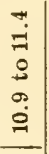 & 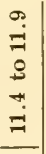 & 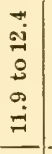 & 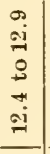 & 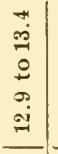 & 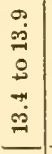 & 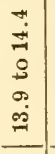 & 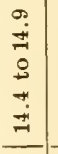 & 吾 \\
\hline 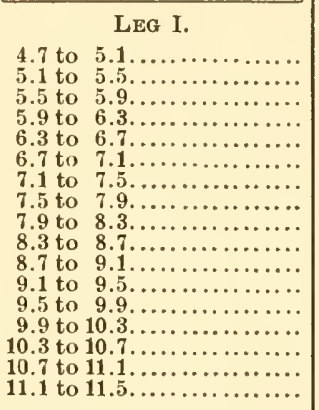 & 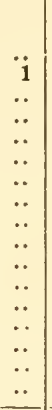 & 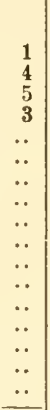 & 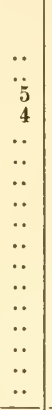 & 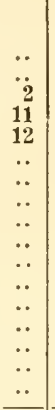 & 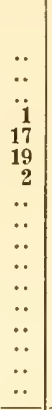 & $\begin{array}{c}. . \\
\ddot{.} \\
\ddot{10} \\
2.2 \\
21 \\
2 \\
. \\
. \\
. \\
. \\
. \\
. \\
. \\
. . \\
\end{array}$ & 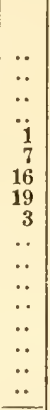 & 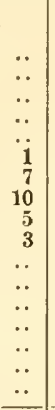 & $\begin{array}{c}. . \\
\because . \\
. . \\
. \\
. \\
\ddot{3} \\
10 \\
13 \\
1 \\
. \\
. . \\
. \\
. \\
. . \\
\end{array}$ & 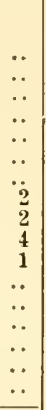 & $\begin{array}{l}. . \\
. . \\
. . \\
. . \\
. \\
. \\
. \\
\ddot{5} \\
6 \\
1 \\
. \\
. \\
.\end{array}$ & $\begin{array}{c}. . \\
. . \\
. . \\
. . \\
. . \\
. \\
\ddot{2} \\
3 \\
4 \\
3 \\
. \\
. . \\
. . \\
\end{array}$ & 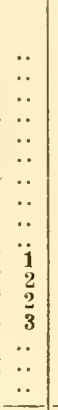 & 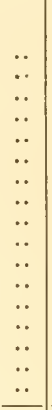 & 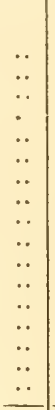 & 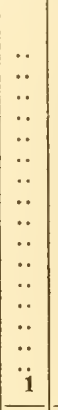 & $\begin{array}{r}1 \\
5 \\
12 \\
19 \\
40 \\
49 \\
46 \\
36 \\
20 \\
22 \\
11 \\
12 \\
6 \\
3 \\
.0 \\
1 \\
\end{array}$ \\
\hline Total ......... & 1 & 13 & 9 & 25 & 39 & 55 & 46 & 26 & 27 & 9 & 12 & 12 & 8 &. &.. & 1 & 283 \\
\hline $\begin{array}{l}\ldots \\
\ldots \\
\ldots \\
\ldots \\
\ldots \\
\ldots \\
\ldots \\
\ldots \\
\ldots \\
\ldots \\
\ldots \\
\ldots \\
\ldots \\
\ldots\end{array}$ & 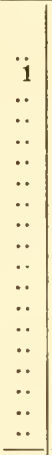 & 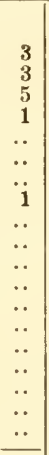 & 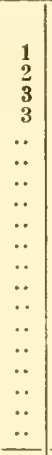 & 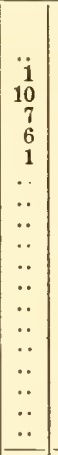 & $\begin{array}{r}. . \\
1 \\
2 \\
15 \\
16 \\
5 \\
. \\
. \\
. \\
. \\
. \\
. \\
.0 \\
\ddot{.} \\
. \\
. \\
.\end{array}$ & $\begin{array}{r}\ddot{.} \\
\ddot{1} \\
3 \\
7 \\
16 \\
15 \\
9 \\
3 \\
\ddot{.} \\
\ddot{.} \\
\ddot{.} \\
\ddot{.} \\
\ddot{.} \\
\ddot{1}\end{array}$ & 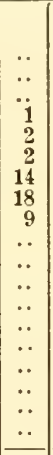 & \begin{tabular}{r|}
$\ddot{.}$ \\
$\ddot{ }$ \\
$\ddot{1}$ \\
2 \\
1 \\
10 \\
7 \\
4 \\
$\ddot{.}$ \\
$\ddot{.}$ \\
$\ddot{.}$ \\
$\ddot{1}$ \\
$\ddot{.}$ \\
$\ddot{.}$
\end{tabular} & 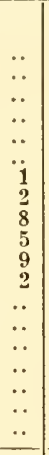 & $\begin{array}{c}. . \\
\ddot{.} \\
\ddot{.} \\
\ddot{0} \\
\ddot{1} \\
. \\
\ddot{1} \\
5 \\
2 \\
. \\
\ddot{.} \\
\ddot{.} \\
\ddot{.} \\
\ddot{.} \\
\end{array}$ & $\begin{array}{c}. . \\
. . \\
. . \\
. . \\
. . \\
. . \\
\ddot{1} \\
1 \\
2 \\
3 \\
3 \\
2 \\
. . \\
. . \\
.\end{array}$ & $\begin{array}{l}. . \\
. . \\
. . \\
. . \\
. \\
. . \\
. \\
\ddot{1} \\
3 \\
4 \\
3 \\
1 \\
. . \\
. . \\
. . \\
\end{array}$ & 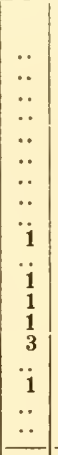 & 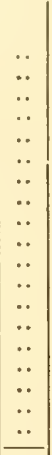 & 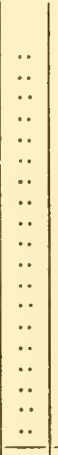 & 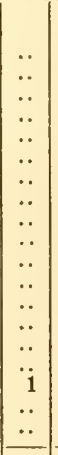 & $\begin{array}{r}4 \\
7 \\
20 \\
17 \\
31 \\
37 \\
37 \\
40 \\
27 \\
12 \\
16 \\
10 \\
8 \\
7 \\
6 \\
1 \\
2\end{array}$ \\
\hline Total......... & 1 & $\overline{13}$ & 9 & 25 & 39 & 55 & $\overline{46}$ & 26 & 27 & 9 & 12 & $\overrightarrow{12}$ & $\overline{8}$ & .. &.. & 1 & 283 \\
\hline 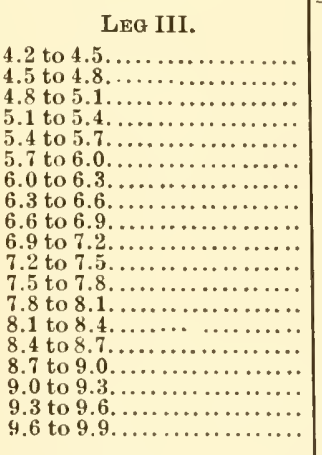 & 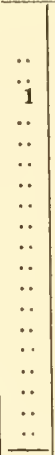 & $\begin{array}{c}2 \\
3 \\
6 \\
2 \\
. . \\
. . \\
. . \\
. . \\
. \\
. \\
. \\
. \\
. \\
. \\
. \\
. \\
. . \\
\end{array}$ & 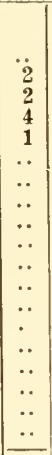 & 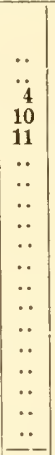 & 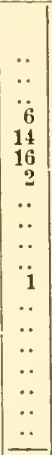 & $\begin{array}{r}. . \\
\ddot{1} \\
2 \\
11 \\
16 \\
20 \\
3 \\
1 \\
. . \\
. . \\
. \\
. . \\
. . \\
. . \\
\ddot{1} \\
. .\end{array}$ & 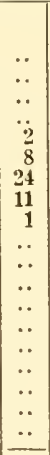 & 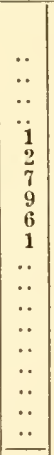 & 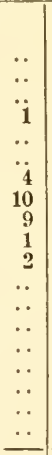 & 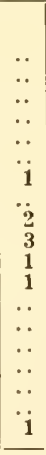 & 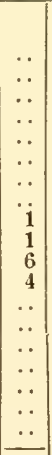 & $\begin{array}{c}. . \\
. \\
\because \\
\because \\
\because \\
\because \\
\because \\
\ddot{4} \\
4 \\
3 \\
1 \\
. \\
\because \\
\because \\
\because \\
. \\
\end{array}$ & \begin{tabular}{|c|}
$\because$ \\
$\because$ \\
$\because$ \\
$\because$ \\
$\because$ \\
$\because$ \\
$\because$ \\
$\because \mathrm{i}$ \\
3 \\
4 \\
$\because$ \\
$\because$ \\
$\because$ \\
$\because$ \\
$\because$ \\
\end{tabular} & 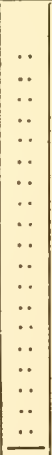 & 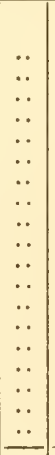 & 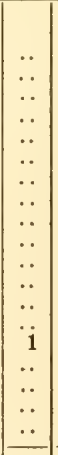 & $\begin{array}{r}2 \\
5 \\
14 \\
25 \\
40 \\
42 \\
58 \\
33 \\
20 \\
10 \\
14 \\
12\end{array}$ \\
\hline Total.................. & 1 & $\overline{13}$ & 9 & 25 & 39 & 55 & 46 & 26 & 27 & 9 & 12 & $\overline{12}$ & $\overline{8}$ & & $\overline{. .}$ & 1 & 283 \\
\hline
\end{tabular}


Table 25.

\begin{tabular}{|c|c|c|c|c|c|c|c|c|c|c|c|c|c|c|c|c|c|}
\hline \multirow[b]{2}{*}{ Length of Propodite. } & \multicolumn{17}{|c|}{ Length of Meripodite, Leg I. } \\
\hline & 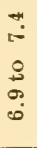 & 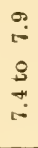 & $\begin{array}{l}\stackrel{\rho}{3} \\
\stackrel{\sigma}{r} \\
\text { - }\end{array}$ & $\begin{array}{l}0 \\
\infty \\
\infty \\
\stackrel{\infty}{\infty} \\
+1\end{array}$ & $\begin{array}{l}\ddot{H} \\
\dot{0} \\
\dot{0} \\
\dot{\infty}\end{array}$ & $\begin{array}{l}0 \\
\text { o } \\
\stackrel{3}{0} \\
\overrightarrow{0}\end{array}$ & $\begin{array}{l}\overrightarrow{0} \\
\dot{0} \\
\dot{0} \\
0 \\
\dot{0}\end{array}$ & $\begin{array}{l}\stackrel{0}{0} \\
\stackrel{0}{1} \\
\stackrel{0}{0} \\
\dot{0} \\
\dot{0}\end{array}$ & $\begin{array}{l}+ \\
\ddot{-} \\
\dot{3} \\
\stackrel{0}{0} \\
\dot{0}\end{array}$ & 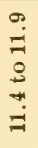 & 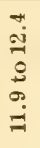 & 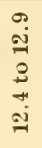 & 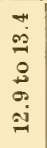 & 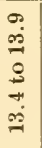 & 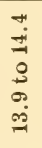 & 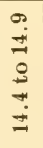 & 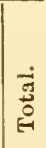 \\
\hline 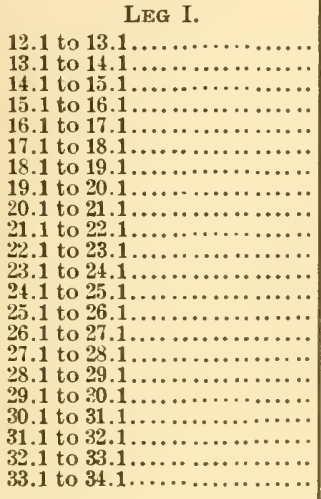 & 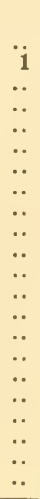 & $\begin{array}{l}1 \\
3 \\
4 \\
4 \\
1 \\
\because . \\
\because . \\
\because . \\
\because . \\
\because . \\
\because . \\
\because \\
\because \\
\because \\
\because \\
\because \\
\because \\
\because \\
\because . \\
\end{array}$ & $\begin{array}{l}\ddot{2} \\
2 \\
5 \\
2 \\
\because . \\
\because . \\
\because \\
\because \\
\because \\
\because \\
\because \\
\because \\
\because \\
\because \\
\because \\
\because \\
\because\end{array}$ & $\begin{array}{r}\ddot{.} \\
\ddot{3} \\
13 \\
6 \\
3 \\
\because . \\
\because \\
\because \\
\because \\
\because \\
\because \\
\because \\
\because \\
\because \\
\because \\
\because \\
\because\end{array}$ & $\begin{array}{r}\ddot{.} \\
\ddot{1} \\
2 \\
8 \\
16 \\
11 \\
1 \\
\because . \\
\because \\
\because . \\
\because \\
\because \\
\because \\
\because \\
\because \\
\because \\
\because \\
\because\end{array}$ & $\begin{array}{r}. . \\
\ddot{.} \\
\ddot{1} \\
9 \\
10 \\
17 \\
11 \\
6 \\
. . \\
\ddot{1} \\
. . \\
. . \\
. \\
. \\
. \\
. \\
. .\end{array}$ & 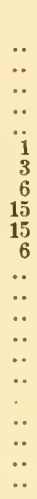 & 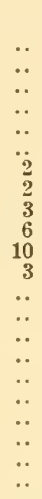 & 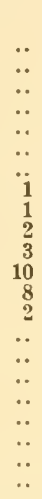 & 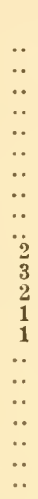 & $\begin{array}{c}. . \\
. . \\
. . \\
\ddot{.} \\
\ddot{.} \\
\ddot{.} \\
\ddot{.} \\
\ddot{.} \\
\ddot{1} \\
4 \\
4 \\
2 \\
1 \\
. . \\
. . \\
. .\end{array}$ & 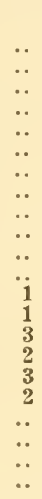 & 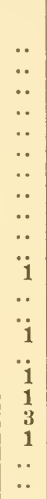 & 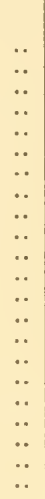 & $\begin{array}{l}. . \\
\ddot{0} \\
\ddot{.} \\
\ddot{.} \\
\ddot{.} \\
\ddot{.} \\
\ddot{.} \\
\ddot{.} \\
\ddot{.} \\
\ddot{.} \\
\ddot{.} \\
\ddot{.} \\
\ddot{.} \\
. .\end{array}$ & 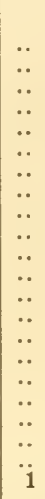 & $\begin{array}{r}1 \\
4 \\
6 \\
13 \\
19 \\
24 \\
34 \\
37 \\
31 \\
29 \\
21 \\
17 \\
12 \\
5 \\
9 \\
6 \\
6 \\
4 \\
3 \\
1 \\
2 \\
1\end{array}$ \\
\hline Total... & 1 & 13 & 9 & 25 & 39 & 55 & 46 & 26 & 27 & 9 & 12 & 12 & 8 & .. & .. & 1 & 283 \\
\hline 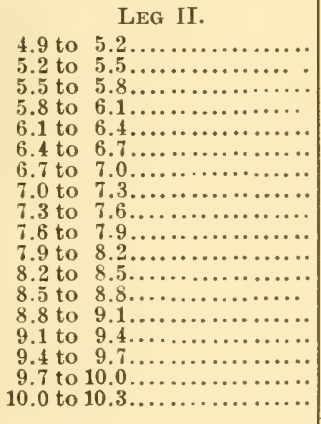 & $\begin{array}{c}1 \\
. . \\
\ddot{.} \\
\ddot{.} \\
\ddot{.} \\
\ddot{. .} \\
\ddot{.} \\
\ddot{.} \\
\ddot{.} \\
\ddot{.} \\
\ddot{.}\end{array}$ & 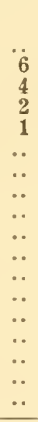 & $\begin{array}{c}\because \\
\ddot{6} \\
2 \\
1 \\
\ddot{1} \\
\because \\
\ddot{.} \\
\because \\
\because \\
\because \\
\because \\
\because \\
\because \\
\because\end{array}$ & 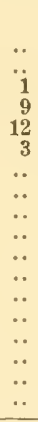 & 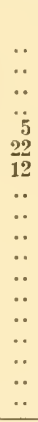 & 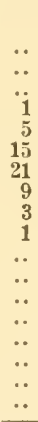 & 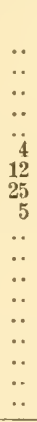 & 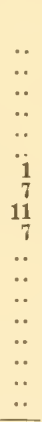 & 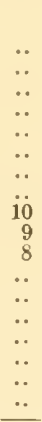 & 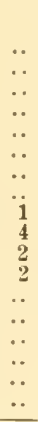 & 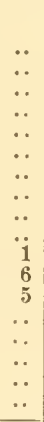 & 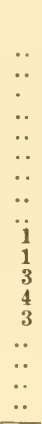 & 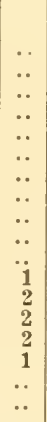 & $\begin{array}{l}\ddot{.} \\
\ddot{.} \\
\ddot{.} \\
\ddot{.} \\
\ddot{.} \\
\ddot{.} \\
\ddot{.} \\
\ddot{.} \\
\ddot{.} \\
\ddot{.} \\
\ddot{.} \\
\ddot{.}\end{array}$ & $\begin{array}{l}\ddot{.} \\
\ddot{.} \\
\ddot{.} \\
\ddot{.} \\
\ddot{.} \\
\ddot{.} \\
\ddot{.} \\
\ddot{.} \\
\ddot{.} \\
\ddot{.} \\
\ddot{.} \\
\ddot{.}\end{array}$ & 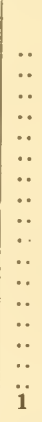 & $\begin{array}{r}1 \\
6 \\
11 \\
14 \\
24 \\
44 \\
46 \\
41 \\
30 \\
22 \\
12 \\
12 \\
11 \\
5 \\
2 \\
1 \\
7 \\
1\end{array}$ \\
\hline Total.................. & 1 & 13 & 9 & 25 & 39 & 55 & 46 & 26 & 27 & 9 & 12 & 12 & 8 & .. & .. & 1 & 283 \\
\hline 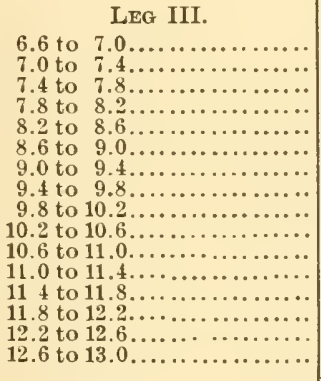 & $\begin{array}{c}\ddot{\mathbf{i}} \\
. \\
\ddot{0} \\
\ddot{.} \\
\ddot{.} \\
\ddot{.} \\
\ddot{.} \\
\ddot{.} \\
\ddot{.} \\
\ddot{.}\end{array}$ & 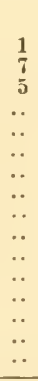 & $\begin{array}{c}\ddot{2} \\
6 \\
1 \\
\ddot{0} \\
\ddot{.} \\
\ddot{.} \\
\ddot{.} \\
\ddot{.} \\
\ddot{.}\end{array}$ & 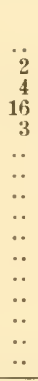 & $\begin{array}{r}\because \\
\dddot{1} \\
7 \\
19 \\
11 \\
1 \\
\because \\
\because \\
\because \\
\because \\
\because \\
\because \\
\because\end{array}$ & $\begin{array}{c}. \\
\because \\
\ddot{4} \\
12 \\
25 \\
12 \\
2 \\
. . \\
\because . \\
\because . \\
. \\
. \\
. \\
.\end{array}$ & 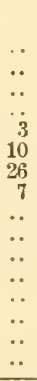 & 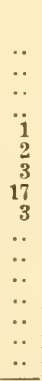 & 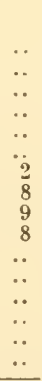 & 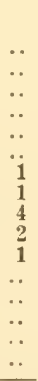 & 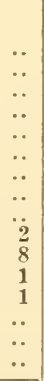 & 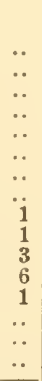 & 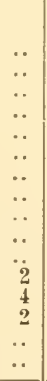 & $\begin{array}{l}\ddot{.} \\
\ddot{.} \\
\ddot{.} \\
. \\
. \\
\ddot{.} \\
\ddot{.} \\
\ddot{.} \\
\ddot{.} \\
\ddot{.} \\
\ddot{.}\end{array}$ & 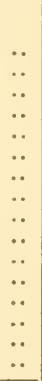 & $\begin{array}{l}\ddot{.} \\
\ddot{.} \\
\ddot{.} \\
\ddot{.} \\
\ddot{.} \\
\ddot{.} \\
\ddot{.} \\
\ddot{.} \\
\ddot{.} \\
\ddot{1}\end{array}$ & $\begin{array}{r}1 \\
12 \\
16 \\
28 \\
38 \\
48 \\
45 \\
35 \\
17 \\
13 \\
12 \\
9 \\
6 \\
2 \\
.1\end{array}$ \\
\hline Total................ & 1 & 13 & 9 & 25) & 39 & 55 & 46 & 26 & 27 & 9 & 12 & 12 & 8 & .. & .. & 1 & 283 \\
\hline
\end{tabular}


Table 26.

\begin{tabular}{|c|c|c|c|c|c|c|c|c|c|c|c|c|c|c|c|c|}
\hline \multirow[b]{2}{*}{ Length of Carpopodite. } & \multicolumn{16}{|c|}{ Length of Meripodite, LeG iI. } \\
\hline & 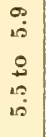 & $\begin{array}{l}m \\
0 \\
\dot{0} \\
0 \\
0 \\
0\end{array}$ & $\begin{array}{l}5 \\
0 \\
0 \\
\infty \\
0\end{array}$ & $\begin{array}{l}7 \\
\therefore \\
0 \\
0 \\
0 \\
0\end{array}$ & $\frac{10}{2}$ & 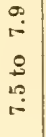 & $\begin{array}{l}m \\
\dot{\infty} \\
\dot{0} \\
0 \\
0 \\
i=\end{array}$ & $\begin{array}{l}- \\
\infty \\
\dot{\infty} \\
\infty \\
\infty\end{array}$ & $\begin{array}{c}\overrightarrow{1} \\
0 \\
\dot{0} \\
\vec{\infty}\end{array}$ & 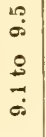 & $\begin{array}{l}\sigma \\
0 \\
0 \\
\dot{0} \\
0 \\
0\end{array}$ & 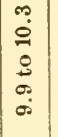 & $\begin{array}{l}\ddot{0} \\
0 \\
0 \\
0 \\
0 \\
0\end{array}$ & 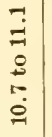 & 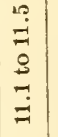 & \\
\hline 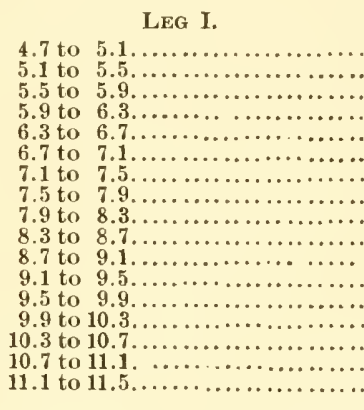 & 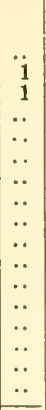 & 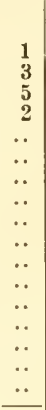 & 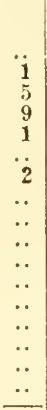 & 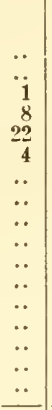 & 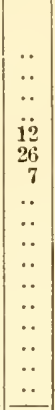 & 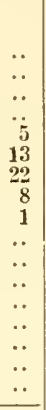 & $\begin{array}{l}\ddot{.} \\
\ddot{.} \\
\ddot{6} \\
11 \\
20 \\
7 \\
2 \\
\ddot{.} \\
\ddot{.} \\
\ddot{.} \\
\ddot{.} \\
\end{array}$ & \begin{tabular}{l|}
.. \\
.. \\
. \\
. \\
$\ddot{3}$ \\
5 \\
8 \\
6 \\
.. \\
. \\
. \\
. \\
. \\
.. \\
\end{tabular} & 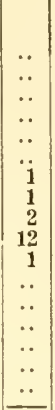 & $\begin{array}{c}. . \\
\ddot{.} \\
\ddot{.} \\
. \\
. \\
\ddot{2} \\
\ddot{2} \\
1 \\
4 \\
5 \\
1 \\
. \\
. \\
. \\
. \\
\end{array}$ & $\begin{array}{c}. . \\
. \\
. \\
. \\
\ddot{.} \\
. \\
\ddot{y} \\
\ddot{1} \\
4 \\
5 \\
3 \\
. \\
\ddot{y} \\
\ddot{.} \\
\end{array}$ & \begin{tabular}{|c}
$\because$. \\
$\because$. \\
$\because$. \\
$\because$. \\
$\because$. \\
$\because \because$ \\
$\because \because$ \\
$\ddot{2}$ \\
2 \\
1 \\
$\because$ \\
$\because$ \\
$\because$ \\
\end{tabular} & 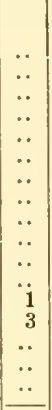 & 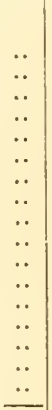 & 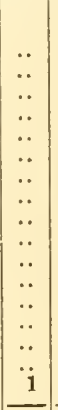 & $\begin{array}{r}1 \\
5 \\
12 \\
19 \\
40 \\
49 \\
48 \\
36 \\
20 \\
22 \\
11 \\
12 \\
6 \\
3 \\
\because \\
1 \\
\end{array}$ \\
\hline Total.......... & 2 & 11 & 18 & $3 \tilde{5}$ & 45 & 49 & 48 & 22 & 17 & 13 & 13 & 5 & 4 & .. & 1 & 283 \\
\hline 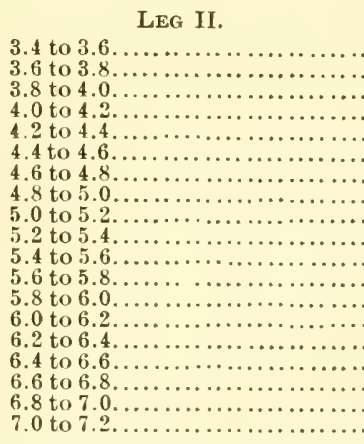 & 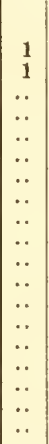 & $\begin{array}{l}2 \\
3 \\
4 \\
2 \\
\because . \\
\because . \\
\because . \\
\because \\
\because \\
\because . \\
\because \\
\because \\
\because \\
\because \\
\because \\
\because . \\
.\end{array}$ & 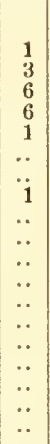 & $\begin{array}{r}\because \\
10 \\
6 \\
14 \\
4 \\
1 \\
. \\
\because \\
\because \\
\because \\
\because \\
\because \\
\because \\
\because \\
\because \\
\because \\
.\end{array}$ & \begin{tabular}{r|}
$\ddot{.}$ \\
$\ddot{2}$ \\
14 \\
19 \\
8 \\
1 \\
. \\
$\ddot{.}$ \\
$\ddot{.}$ \\
. \\
$\ddot{.}$ \\
$\ddot{.}$ \\
$\ddot{.}$ \\
$\ddot{1}$
\end{tabular} & 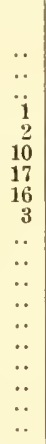 & $\begin{array}{r}. . \\
. . \\
. \\
\ddot{4} \\
10 \\
18 \\
13 \\
2 \\
1 \\
. . \\
. \\
. \\
. \\
. \\
. \\
. .\end{array}$ & 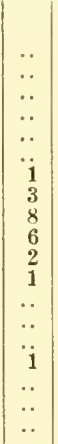 & $\begin{array}{l}. . \\
. \\
. \\
. \\
. \\
. \\
\ddot{1} \\
3 \\
2 \\
9 \\
2 \\
. . \\
. \\
. \\
. \\
. \\
. .\end{array}$ & \begin{tabular}{l|}
.. \\
$\ddot{.}$ \\
. \\
. \\
. \\
. \\
$\because$ \\
$\ddot{3}$ \\
4 \\
1 \\
3 \\
2 \\
. \\
. \\
$\ddot{.}$
\end{tabular} & \begin{tabular}{|l|}
$\because$ \\
$\because$ \\
$\because$. \\
$\because$ \\
$\because$ \\
$\because$ \\
$\because$ \\
$\ddot{1}$ \\
1 \\
3 \\
5 \\
2 \\
1 \\
$\because$. \\
$\because$. \\
$\because$. \\
.
\end{tabular} & 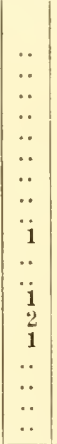 & $\begin{array}{l}\ddot{.} \\
\ddot{.} \\
\ddot{.} \\
\ddot{.} \\
\ddot{.} \\
\ddot{.} \\
\ddot{1} \\
\ddot{2} \\
\ddot{1} \\
\ddot{.}\end{array}$ & 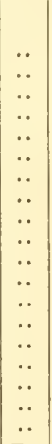 & 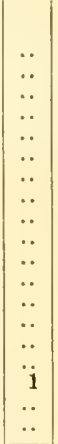 & $\begin{array}{r} \\
27 \\
11 \\
31 \\
37 \\
37 \\
40 \\
27 \\
12 \\
16 \\
10 \\
8 \\
7 \\
6 \\
1 \\
2 \\
1 \\
1\end{array}$ \\
\hline Total....... & 2 & 11 & 18 & 35 & 45 & $\overline{49}$ & $\overline{48}$ & $\overline{22}$ & $\overline{17}$ & 13 & 13 & 5 & 4 & .. & 1 & 283 \\
\hline 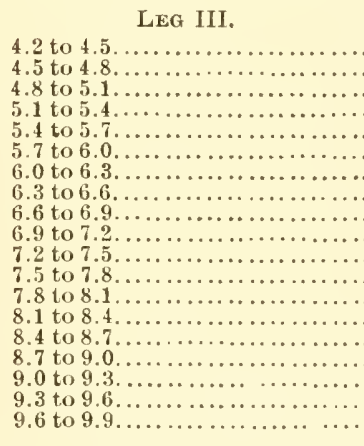 & 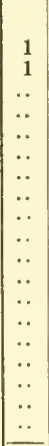 & $\begin{array}{c}1 \\
2 \\
4 \\
4 \\
\because . \\
\because \\
\because \\
\because \\
\because \\
\because \\
\because \\
\because \\
\because \\
\because \\
\because \\
\because \\
\because \\
.\end{array}$ & $\begin{array}{c}\ddot{2} \\
8 \\
4 \\
2 \\
1 \\
1 \\
. \\
\because . \\
. \\
. \\
. \\
. \\
. \\
. \\
. \\
. \\
. .\end{array}$ & 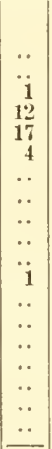 & 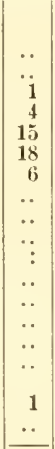 & 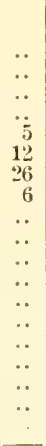 & 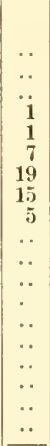 & 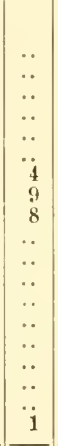 & 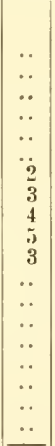 & 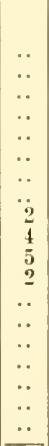 & \begin{tabular}{|c|}
$\because$. \\
$\because$. \\
$\because$. \\
$\because$. \\
$\because$. \\
$\ddot{1}$ \\
1 \\
4 \\
7 \\
$\because$. \\
$\because$. \\
$\because$. \\
$\because$. \\
\end{tabular} & 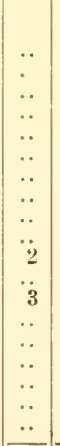 & 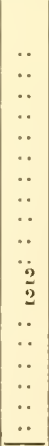 & 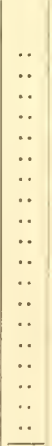 & 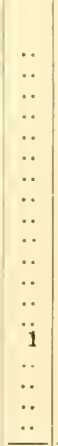 & $\begin{array}{r}5 \\
5 \\
14 \\
25 \\
40 \\
42 \\
58 \\
33 \\
50 \\
10 \\
14 \\
12 \\
5\end{array}$ \\
\hline Total... . . . . & 2 & 11 & 18 & 35 & $4 \pi$ & 49 & 48 & 22 & 17 & 13 & 13 & 5 & 4 & .. & 1 & 283 \\
\hline
\end{tabular}


Table 26.-Continued.

\begin{tabular}{|c|c|c|c|c|c|c|c|c|c|c|c|c|c|c|c|c|}
\hline \multirow[b]{2}{*}{ Length of Propodite. } & \multicolumn{16}{|c|}{ LENGTH OF MERIPODITE, LEG II. } \\
\hline & $\begin{array}{l}\text { is } \\
\text { is } \\
8 \\
\text { in } \\
\text { in }\end{array}$ & 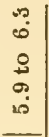 & 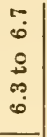 & 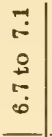 & 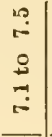 & 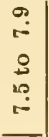 & 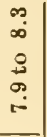 & $\underset{\infty}{\infty}$ & 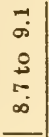 & \begin{tabular}{|c|}
20 \\
$\infty$ \\
$\infty$ \\
$\dot{0}$ \\
0
\end{tabular} \mid & $\begin{array}{l}9 \\
\dot{0} \\
\dot{1} \\
10 \\
0\end{array}$ & $\begin{array}{l}0 \\
\stackrel{0}{0} \\
0 \\
0 \\
0 \\
0\end{array}$ & $\begin{array}{l}5: \\
\stackrel{0}{0} \\
\dot{0} \\
0 \\
0\end{array}$ & 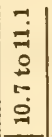 & 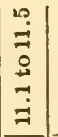 & 苛 \\
\hline $\begin{array}{l}\text { LEG I. } \\
12.1 \text { to } 13.1 \ldots \ldots \ldots \ldots \\
13.1 \text { to } 14.1 \ldots \ldots \ldots \ldots \\
14.1 \text { to } 15.1 \ldots \ldots \ldots \ldots\end{array}$ & 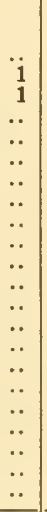 & $\begin{array}{l}\ddot{3} \\
3 \\
4 \\
1 \\
\because \\
\because \\
\because \\
\because \\
\because \\
\because \\
\because \\
\because \\
\because \\
\because \\
\because \\
\because \\
\ddot{.} \\
.\end{array}$ & $\begin{array}{c}1 \\
\ddot{2} \\
7 \\
6 \\
. . \\
\ddot{2} \\
\ddot{2} \\
. . \\
\ddot{.} \\
\ddot{.} \\
\ddot{.} \\
\ddot{.} \\
\ddot{.} \\
\ddot{.} \\
. . \\
. .\end{array}$ & 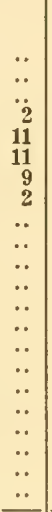 & 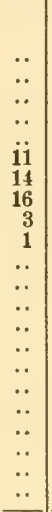 & 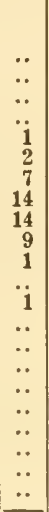 & 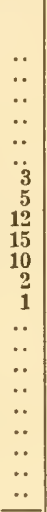 & 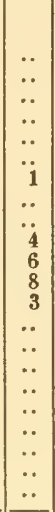 & $\begin{array}{c}. \ddot{ } \\
\ddot{.} \\
\ddot{.} \\
\ddot{.} \\
\ddot{.} \\
\ddot{.} \\
\ddot{3} \\
5 \\
5 \\
3 \\
1 \\
. \\
\ddot{.} \\
\ddot{.} \\
\ddot{.} \\
\end{array}$ & 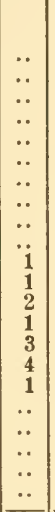 & $\begin{array}{c}. \ddot{ } \\
\ddot{.} \\
\ddot{.} \\
\ddot{.} \\
\ddot{.} \\
\ddot{.} \\
\ddot{.} \\
\ddot{.} \\
\ddot{1} \\
4 \\
2 \\
3 \\
3 \\
\ddot{.} \\
\ddot{.} \\
\end{array}$ & 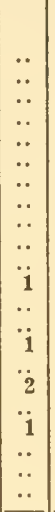 & 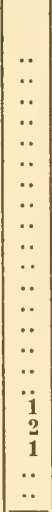 & 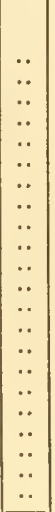 & $\begin{array}{c}. \ddot{ } \\
\ddot{.} \\
\ddot{.} \\
\ddot{.} \\
\ddot{.} \\
\ddot{.} \\
\ddot{.} \\
\ddot{.} \\
\ddot{.} \\
\ddot{.} \\
\ddot{.} \\
\ddot{.} \\
\ddot{1}\end{array}$ & $\begin{array}{r}1 \\
4 \\
6 \\
13 \\
19 \\
24 \\
34 \\
37 \\
31 \\
29 \\
21 \\
17 \\
12 \\
5 \\
9 \\
6 \\
6 \\
4 \\
3 \\
1 \\
\ddot{1}\end{array}$ \\
\hline Total ................... & 2 & 11 & 18 & 35 & 45 & 49 & 48 & 22 & 17 & 13 & 13 & 5 & 4 & .. & $1:$ & 283 \\
\hline 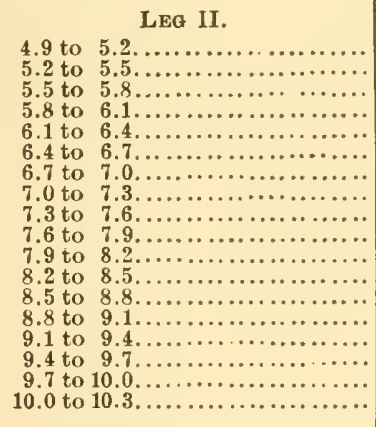 & 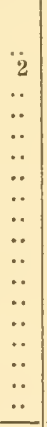 & 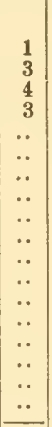 & 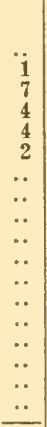 & 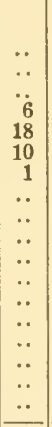 & 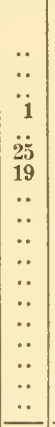 & 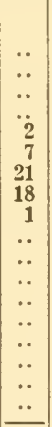 & 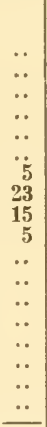 & 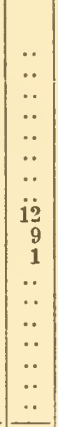 & $\begin{array}{c}\because . \\
\ddot{.} \\
\ddot{.} \\
\ddot{.} \\
\ddot{2} \\
6 \\
8 \\
1 \\
\ddot{.} \\
\ddot{.} \\
\ddot{.} \\
. .\end{array}$ & $\begin{array}{c}\ddot{.} \\
\ddot{.} \\
\ddot{.} \\
\ddot{.} \\
\ddot{.} \\
\ddot{2} \\
\mathbf{1} \\
6 \\
4 \\
\ddot{.} \\
\ddot{.} \\
\ddot{.}\end{array}$ & 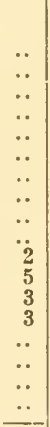 & \begin{tabular}{|l}
$\ddot{.}$ \\
$\ddot{.}$ \\
$\ddot{.}$ \\
$\ddot{.}$ \\
$\ddot{.}$ \\
$\ddot{.}$ \\
$\ddot{.}$ \\
$\ddot{4}$ \\
.1 \\
$\ddot{.}$ \\
$\ddot{.}$ \\
\end{tabular} & $\begin{array}{l}. . \\
. . \\
. . \\
. . \\
. . \\
. . \\
. . \\
. . \\
.0 \\
\ddot{1} \\
\frac{2}{1} \\
. . \\
. .\end{array}$ & 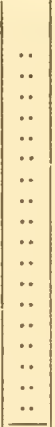 & 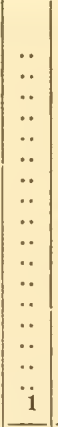 & $\begin{array}{r}1 \\
6 \\
11 \\
14 \\
24 \\
44 \\
46 \\
41 \\
30 \\
22 \\
12 \\
12 \\
11 \\
5 \\
2 \\
1 \\
11\end{array}$ \\
\hline Total........... & 2 & 11 & 18 & 35 & 45 & 49 & 48 & 22 & 17 & 13 & 13 & 5 & 4 & .. & 1 & 283 \\
\hline 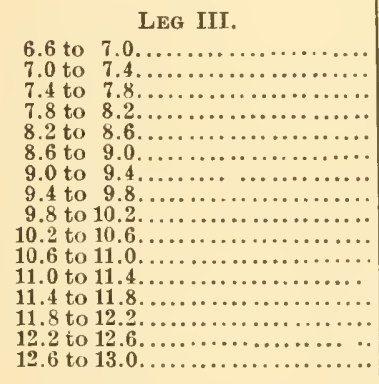 & $\begin{array}{l}1 \\
. \\
. \\
. \\
. \\
\ddot{.} \\
\ddot{.} \\
\ddot{.} \\
\ddot{.} \\
. .\end{array}$ & $\begin{array}{c}\ddot{6} \\
\mathbf{5} \\
. \\
\ddot{*} \\
\ddot{.} \\
\because \\
\because \\
\because \\
\because \\
\because \\
\because . \\
\because .\end{array}$ & $\begin{array}{c}\ddot{4} \\
8 \\
3 \\
1 \\
\ddot{2} \\
. \\
\ddot{.} \\
\because \\
\because \\
\because \\
\ddot{.} \\
.\end{array}$ & 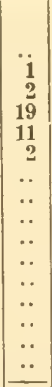 & $\begin{array}{c}\ddot{1} \\
5 \\
20 \\
16 \\
3 \\
. \\
\because \\
\because \\
\because \\
\because \\
\because \\
\because \\
.\end{array}$ & 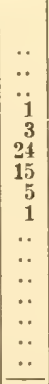 & 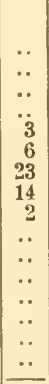 & 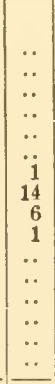 & 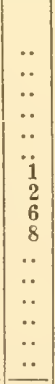 & 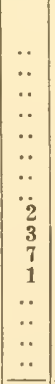 & $\begin{array}{l}\because . . \\
\because . . \\
\because . . \\
\because . \\
\because . \\
\ddot{1} \\
5 \\
5 \\
2 \\
\because . \\
\because . .\end{array}$ & 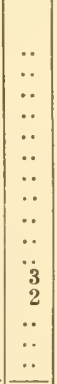 & $\begin{array}{l}\ddot{.} \\
\ddot{.} \\
. \\
. \\
. . \\
. . \\
. \\
\ddot{2} \\
\ddot{2} \\
. \\
.\end{array}$ & 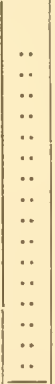 & 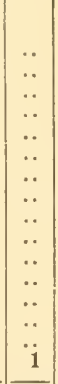 & $\begin{array}{r}1 \\
12 \\
16 \\
28 \\
38 \\
48 \\
45 \\
35 \\
17 \\
13 \\
12 \\
9\end{array}$ \\
\hline Total................... & 2 & 11 & 18 & 35 & 45 & 49 & 48 & 22 & 17 & 13 & 13 & 5 & 4 &. & 1 & 283 \\
\hline
\end{tabular}


TABle 26.-Continued.

\begin{tabular}{|c|c|c|c|c|c|c|c|c|c|c|c|c|c|c|c|c|}
\hline \multirow[b]{2}{*}{ LENGTH OF MERIPODITE. } & \multicolumn{16}{|c|}{ Length of Meripodite, Leg II. } \\
\hline & 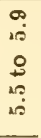 & $\begin{array}{l}0 \\
0 \\
0 \\
0 \\
0 \\
0 \\
10\end{array}$ & $\mid \begin{array}{l}5 \\
0 \\
0 \\
0 \\
0 \\
0 \\
0\end{array}$ & 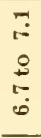 & 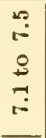 & 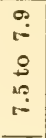 & $\begin{array}{l}0 \\
\infty \\
\dot{0} \\
\dot{0} \\
0\end{array}$ & $\begin{array}{l}r \\
\infty \\
\infty \\
\infty \\
\infty \\
\infty\end{array}$ & $\begin{array}{l}\overrightarrow{1} \\
\dot{0} \\
\dot{0} \\
5\end{array}$ & $\begin{array}{l}10 \\
0 \\
8 \\
0 \\
0\end{array}$ & $\mid \begin{array}{c}0 \\
0 \\
0 \\
\vdots \\
10 \\
0 \\
0\end{array}$ & $\begin{array}{l}\stackrel{0}{0} \\
\stackrel{0}{0} \\
\stackrel{0}{0} \\
\stackrel{0}{0}\end{array}$ & $\begin{array}{l}10 \\
\stackrel{0}{0} \\
0 \\
0 \\
0 \\
0\end{array}$ & $\begin{array}{l}= \\
\vdots \\
0 \\
0 \\
0\end{array}$ & 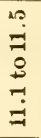 & \\
\hline 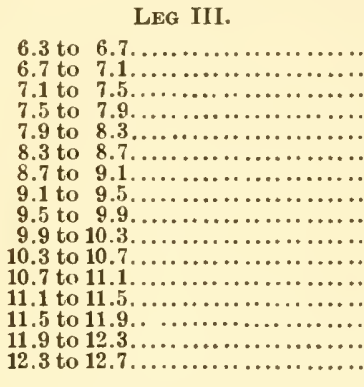 & 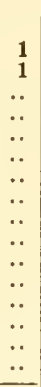 & $\begin{array}{c}\ddot{6} \\
5 \\
\ddot{.} \\
\ddot{.} \\
\ddot{~} \\
\ddot{~} \\
\ddot{~} \\
\ddot{~} \\
\ddot{~} \\
\ddot{.}\end{array}$ & $\begin{array}{c}\ddot{2} \\
10 \\
4 \\
\ddot{1} \\
1 \\
\ddot{0} \\
\because \\
\because \\
\because \\
\because \\
\because \\
\because\end{array}$ & 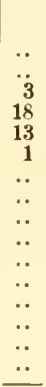 & $\begin{array}{c}\ddot{.} \\
\ddot{3} \\
2 \\
19 \\
1 \\
. \\
\ddot{.} \\
\ddot{.} \\
\ddot{.} \\
\ddot{.} \\
. .\end{array}$ & 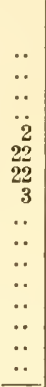 & 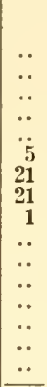 & 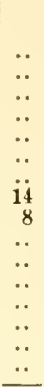 & 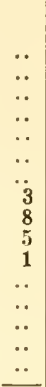 & $\begin{array}{l}\therefore \\
\ddot{.} \\
\ddot{.} \\
. \\
\ddot{1} \\
7 \\
3 \\
2 \\
. \\
\ddot{.}\end{array}$ & 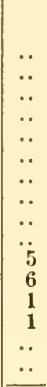 & $\begin{array}{l}\ddot{.} \\
\ddot{.} \\
. \\
. \\
\ddot{.} \\
\ddot{.} \\
\ddot{3} \\
\ddot{3} \\
2 \\
.0 \\
. .\end{array}$ & $\begin{array}{l}\ddot{.} \\
\ddot{.} \\
\ddot{.} \\
. \\
\ddot{.} \\
\ddot{0} \\
\ddot{1} \\
2 \\
. \\
.\end{array}$ & $\begin{array}{l}. . \\
. . \\
\ddot{.} \\
. . \\
. . \\
. . \\
. . \\
. . \\
. . \\
. .\end{array}$ & $\begin{array}{l}\ddot{.} \\
\ddot{.} \\
\ddot{.} \\
\ddot{.} \\
\ddot{.} \\
\ddot{.} \\
\ddot{.} \\
\ddot{0} \\
\ddot{1}\end{array}$ & $\begin{array}{r}1 \\
9 \\
18 \\
25 \\
37 \\
48 \\
45 \\
41 \\
18 \\
12 \\
9 \\
12 \\
4 \\
3 \\
\text { i }\end{array}$ \\
\hline Total............ & 2 & 11 & 18 & 35 & 45 & 49 & 48 & 22 & 17 & 13 & 13 & 5 & 4 & .. & 1 & 283 \\
\hline
\end{tabular}


TABLES OF MEASUREMENTS.

TABLE 27.

\begin{tabular}{|c|c|c|c|c|c|c|c|c|c|c|c|c|c|c|c|c|c|}
\hline \multirow[b]{2}{*}{ LENGTH OF CARPOPODITE. } & \multicolumn{17}{|c|}{ Length of Meripodite, LEG III. } \\
\hline & \begin{tabular}{l}
$\square$ \\
\hdashline \\
0 \\
0 \\
0
\end{tabular} & $\begin{array}{l}\square \\
\vdots \\
0 \\
0\end{array}$ & $\begin{array}{l}\stackrel{2}{2} \\
\stackrel{0}{+} \\
\stackrel{1}{\circ}\end{array}$ & $\begin{array}{l}\stackrel{0}{0} \\
i \\
\stackrel{2}{2} \\
\stackrel{2}{0}\end{array}$ & 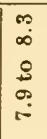 & $\begin{array}{l}\square \\
\infty \\
\infty \\
\infty \\
\infty\end{array}$ & $\begin{array}{l}-1 \\
0 \\
0 \\
\dot{0} \\
\infty\end{array}$ & $\begin{array}{l}\stackrel{0}{0} \\
\stackrel{0}{\circ} \\
\dot{0}\end{array}$ & $\begin{array}{l}\dot{0} \\
\dot{0} \\
\dot{8} \\
\dot{0}\end{array}$ & 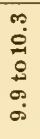 & $\begin{array}{l}\square \\
0 \\
0 \\
\dot{8} \\
\ddot{0} \\
\ddot{0}\end{array}$ & 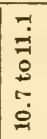 & 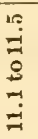 & 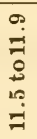 & 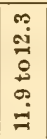 & 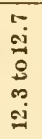 & 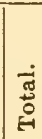 \\
\hline 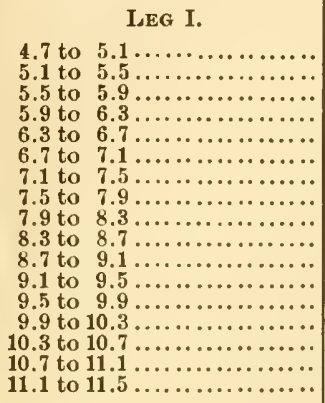 & 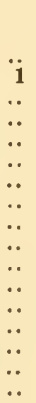 & 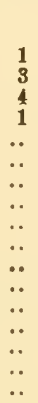 & $\begin{array}{c}\ddot{1} \\
6 \\
8 \\
3 \\
\ddot{0} \\
\ddot{0} \\
\ddot{0} \\
\ddot{0} \\
\ddot{0} \\
\ddot{y}\end{array}$ & 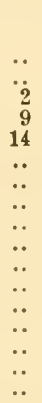 & 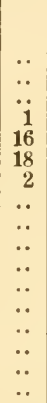 & $\begin{array}{c}\ddot{.} \\
\ddot{.} \\
\ddot{7} \\
21 \\
15 \\
5 \\
\ddot{.} \\
\ddot{.} \\
\ddot{0} \\
\ddot{0} \\
\ddot{.}\end{array}$ & 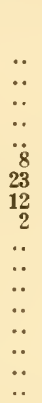 & 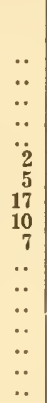 & 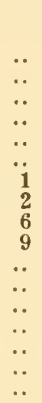 & $\begin{array}{c}\ddot{.} \\
\ddot{.} \\
\ddot{.} \\
\ddot{.} \\
\ddot{.} \\
\ddot{2} \\
4 \\
3 \\
3 \\
\ddot{3} \\
\ddot{.} \\
\ddot{.}\end{array}$ & $\begin{array}{c}\ddot{.} \\
\ddot{.} \\
\ddot{.} \\
\ddot{.} \\
\ddot{~} \\
\ddot{2} \\
\ddot{2} \\
5 \\
2 \\
\ddot{.} \\
\ddot{.} \\
\ddot{.}\end{array}$ & 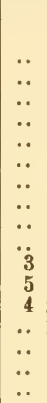 & 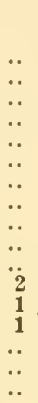 & $\begin{array}{l}\ddot{.} \\
\ddot{.} \\
\ddot{.} \\
\ddot{.} \\
\ddot{.} \\
\ddot{.} \\
\ddot{.} \\
\ddot{1} \\
2 \\
\ddot{.} \\
\ddot{.}\end{array}$ & $\begin{array}{l}\ddot{.} \\
\ddot{.} \\
\ddot{.} \\
\ddot{.} \\
\ddot{.} \\
\ddot{.} \\
\ddot{.} \\
\ddot{.} \\
\ddot{.} \\
\ddot{.}\end{array}$ & $\begin{array}{l}\ddot{.} \\
\ddot{.} \\
\ddot{.} \\
\ddot{.} \\
\ddot{.} \\
\ddot{.} \\
\ddot{~} \\
\ddot{~} \\
\ddot{.} \\
\ddot{1}\end{array}$ & $\begin{array}{r}1 \\
5 \\
12 \\
19 \\
40 \\
49 \\
46 \\
36 \\
20 \\
22 \\
11 \\
12 \\
6 \\
3 \\
\because \\
\ddot{1}\end{array}$ \\
\hline Total.. & 1 & 9 & 18 & 25 & 37 & 48 & 45 & 41 & 18 & 12 & 9 & 12 & 4 & 3 & .. & 1 & 283 \\
\hline 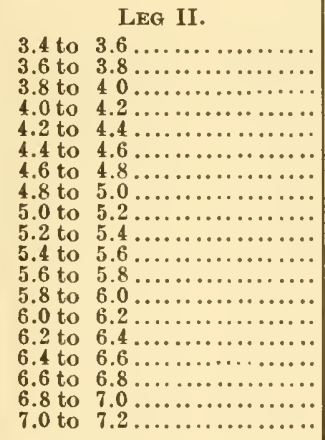 & 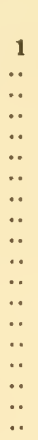 & $\begin{array}{l}\mathbf{1} \\
3 \\
4 \\
1 \\
\because . \\
\because \\
\because \\
\because \\
\because \\
\because \\
\because \\
\because \\
\because \\
\because \\
\because \\
\because \\
\because\end{array}$ & $\begin{array}{c}\mathbf{1} \\
\mathbf{4} \\
5 \\
4 \\
3 \\
. . \\
\ddot{1} \\
\ddot{.} \\
\because \\
. \\
\because \\
\because \\
\ddot{.} \\
\because \\
\because \\
. .\end{array}$ & $\begin{array}{c}1 \\
\ddot{9} \\
7 \\
6 \\
1 \\
1 \\
. \\
\because \\
\because \\
\because \\
\because \\
\because \\
\because \\
\because \\
\because \\
\because \\
.\end{array}$ & 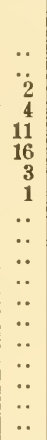 & 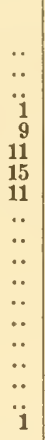 & 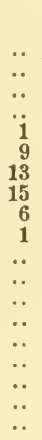 & $\begin{array}{r}\because . . \\
\because . \\
\ddot{1} \\
\ddot{5} \\
11 \\
15 \\
6 \\
2 \\
. . \\
. \\
\ddot{2} \\
\ddot{1} \\
\because . . \\
. .\end{array}$ & $\begin{array}{c}. . \\
. . \\
. . \\
. \\
\because \\
\ddot{1} \\
5 \\
3 \\
7 \\
2 \\
. \\
\because . \\
\because \\
\because . \\
. .\end{array}$ & 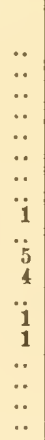 & $\begin{array}{c}. . \\
. . \\
. . \\
. . \\
. . \\
. . \\
\ddot{1} \\
1 \\
1 \\
3 \\
3 \\
. . \\
. . \\
. .\end{array}$ & $\begin{array}{c}. . \\
\because \\
\because . \\
\because . \\
\ddot{.} \\
\because \\
\ddot{1} \\
1 \\
3 \\
3 \\
2 \\
2 \\
. \\
\because \\
\because .\end{array}$ & 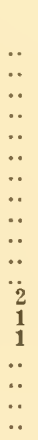 & 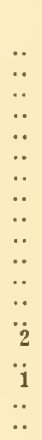 & 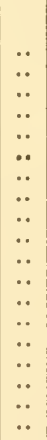 & 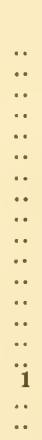 & $\begin{array}{r}4 \\
7 \\
20 \\
17 \\
31 \\
37 \\
37 \\
40 \\
27 \\
12 \\
16 \\
10 \\
8 \\
7 \\
6 \\
1 \\
2 \\
\ddot{1}\end{array}$ \\
\hline Total.. & 1 & 9 & 18 & 25 & 37 & 48 & 45 & 41 & 18 & 12 & 9 & 12 & 4 & 3 & .. & 1 & 283 \\
\hline 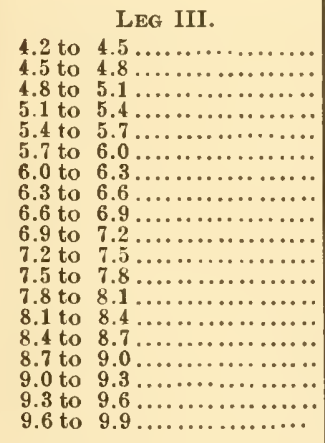 & 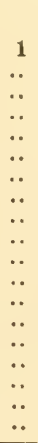 & $\begin{array}{c}1 \\
3 \\
4 \\
1 \\
\because . \\
\because \\
\because \\
\because \\
\because \\
\because \\
\because \\
\because \\
\because \\
. \\
. \\
.\end{array}$ & 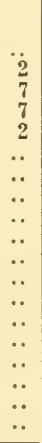 & 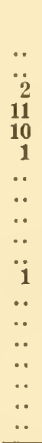 & 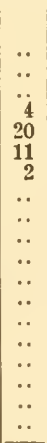 & 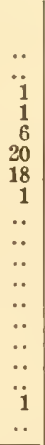 & 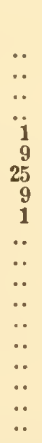 & 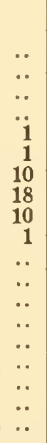 & $\begin{array}{c}\because \\
\because \\
\ddot{1} \\
\because \\
\ddot{2} \\
5 \\
7 \\
1 \\
1 \\
\because \\
\because \\
\because \\
\because \\
\ddot{1}\end{array}$ & 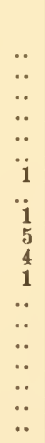 & 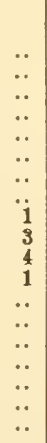 & 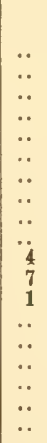 & $\begin{array}{c}. . \\
. . \\
. . \\
. . \\
. \\
. \\
. \\
\ddot{1} \\
1 \\
2 \\
. . \\
. \\
. \\
\ddot{.}\end{array}$ & 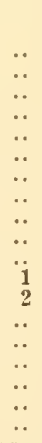 & 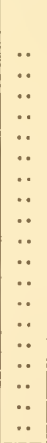 & $\begin{array}{l}\ddot{.} \\
\ddot{.} \\
\ddot{.} \\
\ddot{.} \\
\ddot{.} \\
\ddot{.} \\
\ddot{.} \\
\ddot{.} \\
\ddot{1} \\
\ddot{.} \\
\ddot{.}\end{array}$ & $\begin{array}{r}2 \\
5 \\
14 \\
25 \\
40 \\
42 \\
58 \\
33 \\
20 \\
10 \\
14 \\
12 \\
5 \\
\ddot{1} \\
. . \\
\ddot{1} \\
1\end{array}$ \\
\hline Total. & 1 & 9 & 18 & 25 & 37 & 48 & 45 & 41 & 18 & 12 & 9 & 12 & 4 & 3 & .. & 1 & 283 \\
\hline
\end{tabular}


TABLE 27.-Continued.

\begin{tabular}{|c|c|c|c|c|c|c|c|c|c|c|c|c|c|c|c|c|c|}
\hline \multirow[b]{2}{*}{ Length of Propodite. } & \multicolumn{17}{|c|}{ LenGth of MERIPOdite, LEG III. } \\
\hline & $\begin{array}{l}\dot{0} \\
\dot{0} \\
\dot{0}\end{array}$ & 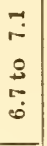 & 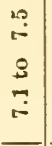 & 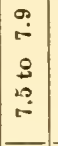 & 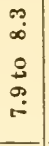 & $\begin{array}{l}- \\
\infty \\
\rho \\
\infty \\
\infty \\
\infty\end{array}$ & $\begin{array}{l}\overrightarrow{0} \\
\dot{0} \\
\dot{\infty} \\
\vec{\infty}\end{array}$ & $\begin{array}{l}\stackrel{s}{0} \\
\dot{0} \\
\dot{\rho} \\
\dot{\sigma}\end{array}$ & $\mid \begin{array}{l}0 \\
0 \\
0 \\
\dot{1} \\
0 \\
\sigma\end{array}$ & 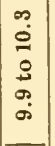 & $\begin{array}{l}\check{0} \\
0 \\
0 \\
\infty \\
0 \\
\varrho\end{array}$ & $\begin{array}{l}\vec{y} \\
\vec{z} \\
\dot{8} \\
0 \\
0\end{array}$ & 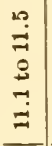 & 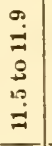 & 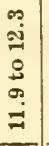 & 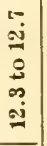 & 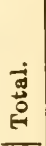 \\
\hline 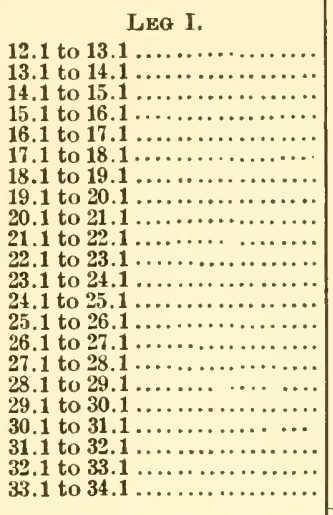 & 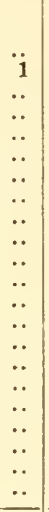 & 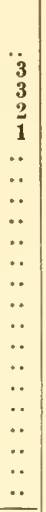 & 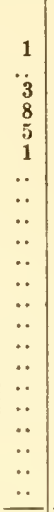 & 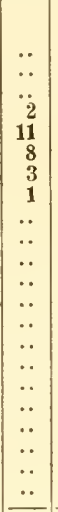 & $\begin{array}{r}. . \\
\ddot{1} \\
\mathbf{1} \\
20 \\
10 \\
7 \\
1 \\
. \\
. \\
. \\
. \\
.0 \\
. \\
. \\
. \\
. \\
. . \\
\end{array}$ & $\begin{array}{c}\because . \\
\because \\
\because \\
\ddot{4} \\
9 \\
22 \\
8 \\
5 \\
. . \\
\because . \\
\because . \\
\because . \\
\because . \\
\because . \\
\because . \\
. . \\
\end{array}$ & 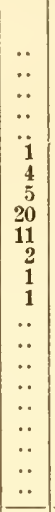 & 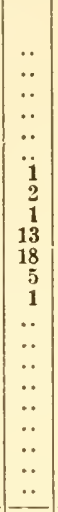 & 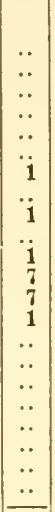 & 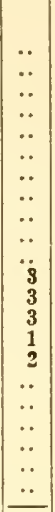 & 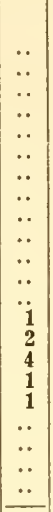 & 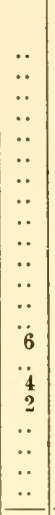 & 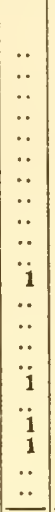 & 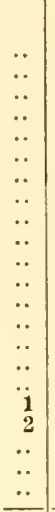 & 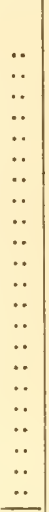 & 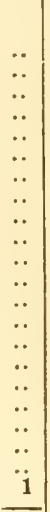 & $\begin{array}{r} \\
5 \\
9 \\
6 \\
6 \\
4 \\
3 \\
1 \\
. .\end{array}$ \\
\hline Total...... & 1 & 9 & 18 & 25 & 37 & 48 & 45 & 41 & 18 & 12 & 9 & 12 & 4 & 3 & .. & 1 & 283 \\
\hline $\begin{array}{r}4.9 \text { to } 5.2 \ldots \ldots \ldots \\
5.2 \text { to } 5.5 \ldots \ldots \ldots \\
5.5 \text { to } 5.8 \ldots \ldots \ldots \\
5.8 \text { to } 6.1 \ldots \ldots \ldots \\
6.1 \text { to } 6.4 \ldots \ldots \ldots \\
6.4 \text { to } 6.7 \ldots \ldots \ldots \\
6.7 \text { to } 7.0 \ldots \ldots \ldots \\
7.0 \text { to } 7.3 \ldots \ldots \ldots \\
7.3 \text { to } 7.6 \ldots \ldots \ldots \\
7.6 \text { to } 7.9 \ldots \ldots \ldots \\
7.9 \text { to } 8.2 \ldots \ldots \ldots \\
8.2 \text { to } 8.5 \ldots \ldots \ldots \\
8.5 \text { to } 8.8 \ldots \ldots \ldots \\
8.8 \text { to } 9.1 \ldots \ldots \ldots \\
99.1 \text { to } 9.4 \ldots \ldots \ldots \\
9.4 \text { to } 9.7 \ldots \ldots \ldots \\
90.7 \text { to } 10.0 \ldots \ldots \ldots \\
10.0 \text { to } 10.3 \ldots \ldots \ldots\end{array}$ & $\begin{array}{l}1 \\
. \\
\ddot{.} \\
. \\
\ddot{.} \\
\ddot{.} \\
\ddot{.} \\
\ddot{.} \\
\ddot{.} \\
\ddot{.} \\
\ddot{.} \\
\end{array}$ & $\begin{array}{c}1 \\
3 \\
3 \\
1 \\
1 \\
. \\
. . \\
. . \\
. . \\
. . \\
. . \\
. . \\
.0 \\
\ddot{.} \\
.\end{array}$ & 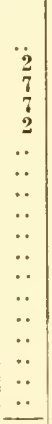 & $\begin{array}{r}\ddot{1} \\
5 \\
13 \\
4 \\
2 \\
. \\
\ddot{.} \\
\ddot{.} \\
\ddot{.} \\
. \\
\ddot{.} \\
\ddot{.} \\
. \\
\end{array}$ & 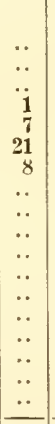 & $\begin{array}{c}\ddot{.} \\
\ddot{.} \\
\ddot{18} \\
23 \\
6 \\
1 \\
. \\
\ddot{.} \\
\ddot{.} \\
\ddot{.} \\
\ddot{.} \\
.\end{array}$ & 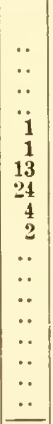 & $\begin{array}{c}\ddot{.} \\
. . \\
. \\
. \\
\ddot{11} \\
22 \\
8 \\
. \\
\ddot{.} \\
\ddot{.} \\
\ddot{.} \\
\ddot{.} \\
\end{array}$ & $\begin{array}{c}. \ddot{ } \\
\ddot{.} \\
\ddot{.} \\
\ddot{3} \\
\ddot{3} \\
10 \\
\tilde{y} \\
\ddot{.} \\
\ddot{.} \\
\ddot{.} \\
\ddot{.} \\
\end{array}$ & \begin{tabular}{|l|}
$\ddot{.}$ \\
$\ddot{.}$ \\
$\ddot{.}$ \\
$\ddot{.}$ \\
$\ddot{z}$ \\
$\ddot{2}$ \\
4 \\
4 \\
2 \\
$\ddot{.}$ \\
$\ddot{.}$ \\
$\ddot{.}$ \\
\end{tabular} & 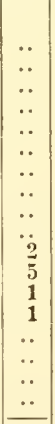 & $\begin{array}{l}\ddot{.} \\
\ddot{.} \\
\ddot{.} \\
\ddot{.} \\
\ddot{.} \\
\ddot{.} \\
\ddot{3} \\
7 \\
. \\
\ddot{.} \\
\ddot{.} \\
\end{array}$ & 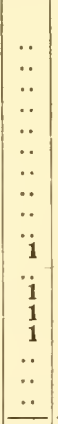 & $\begin{array}{l}\ddot{.} \\
\ddot{.} \\
\ddot{.} \\
\ddot{.} \\
\ddot{.} \\
. \\
\ddot{.} \\
\ddot{1} \\
1 \\
1 \\
\ddot{.} \\
\end{array}$ & 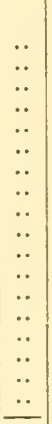 & $\begin{array}{l}. \ddot{.} \\
. \\
. \\
\ddot{.} \\
\ddot{.} \\
\ddot{.} \\
\ddot{.} \\
. .\end{array}$ & $\begin{array}{r}1 \\
8 \\
11 \\
14 \\
24 \\
44 \\
46 \\
41\end{array}$ \\
\hline Total. . & 1 & 9 & 18 & 25 & 37 & 48 & 45 & 41 & 18 & 12 & 9 & 12 & 4 & 3 & .. & 1 & 283 \\
\hline $\begin{array}{l}6.6 \text { to } 7.0 . \\
7.0 \text { to } 7.4 . \\
7.4 \text { to } 7.8 . \\
7.8 \text { to } 8.2 . \\
8.2 \text { to } 8.6 . \\
8.6 \text { to } 9.0 . \\
9.0 \text { to } 9.4 . \\
9.4 \text { to } 9.8 \\
9.8 \text { to } 10.2 . \\
10.2 \text { to } 10.6 . \\
10.6 \text { to } 11.0 \ldots \\
11.0 \text { to } 11.4 . \\
11.4 \text { to } 11.8 . \\
11.8 \text { to } 12.2 . \\
12.2 \text { to } 12.6 . \\
12.6 \text { to } 13.0 .\end{array}$ & $\begin{array}{l}\because . \\
\ddot{.} \\
\ddot{.} \\
\ddot{.} \\
\because \\
\because . \\
\because . \\
\because . \\
\end{array}$ & \begin{tabular}{c|}
1 \\
6 \\
2 \\
. \\
. \\
. \\
. \\
. \\
. \\
. \\
. \\
. \\
. \\
.. \\
\end{tabular} & 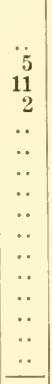 & $\begin{array}{c}\because \\
3 \\
\mathbf{1} \\
7 \\
. \\
\because \\
\because \\
\because \\
\because \\
\because . \\
\because \\
\because . \\
\because . \\
\end{array}$ & \begin{tabular}{|c|}
$\ddot{.}$ \\
$\ddot{9}$ \\
21 \\
6 \\
1 \\
. \\
. \\
. \\
. \\
. \\
. \\
. \\
$\ddot{.}$ \\
.. \\
\end{tabular} & \begin{tabular}{c|}
$\ddot{.}$ \\
$\ddot{2}$ \\
8 \\
26 \\
12 \\
$\ddot{.}$ \\
$\ddot{.}$ \\
$\ddot{.}$ \\
$\ddot{.}$ \\
$\ddot{.}$ \\
. \\
\end{tabular} & \begin{tabular}{|l|}
$\because$. \\
. \\
$\ddot{1}$ \\
16 \\
18 \\
10 \\
$\because$ \\
$\because$. \\
$\because$. \\
. \\
. \\
.. \\
\end{tabular} & 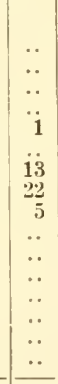 & $\begin{array}{r}. . \\
. \\
. \\
. \\
\ddot{.} \\
1 \\
3 \\
10 \\
4 \\
. . \\
. \\
. \\
. \\
. \\
. . \\
\end{array}$ & 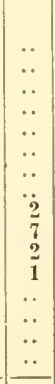 & $\begin{array}{l}. \ddot{ } \\
\ddot{.} \\
\ddot{.} \\
. \\
. \\
\ddot{ } \\
\ddot{2} \\
6 \\
\mathbf{1} \\
. \\
\ddot{.} \\
\ddot{.} \\
\end{array}$ & $\begin{array}{l}\ddot{.} \\
\ddot{.} \\
\ddot{0} \\
\ddot{.} \\
\ddot{.}\end{array}$ & 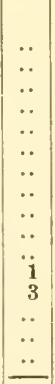 & 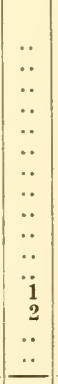 & $\begin{array}{l}\ddot{.} \\
\ddot{.}\end{array}$ & & $\begin{array}{l}1 \\
12 \\
16 \\
28 \\
38 \\
48 \\
45 \\
35 \\
17 \\
1: \\
13 \\
6 \\
3\end{array}$ \\
\hline Total. & 1 & 9 & 18 & 25 & 37 & 48 & 45 & 41 & 18 & 12 & 9 & 12 & 4 & 3 & $\cdot \cdot$ & & 283 \\
\hline
\end{tabular}


TABLES OF MEASUREMENTS.

TABLe 28.

\begin{tabular}{|c|c|c|c|c|c|c|c|c|c|c|c|c|c|c|c|c|c|c|}
\hline \multirow[b]{2}{*}{$\begin{array}{l}\text { LRNGTH OF } \\
\text { CARPOPODITE. }\end{array}$} & \multicolumn{18}{|c|}{ LENGTH OF CARPOPODITE, LEG I. } \\
\hline & 20 & 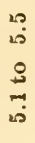 & 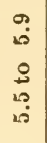 & 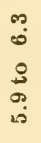 & 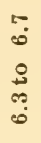 & $\begin{array}{l}\ddot{4} \\
\stackrel{5}{5} \\
\stackrel{0}{0}\end{array}$ & 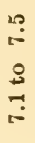 & 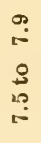 & $\begin{array}{l}\infty \\
\infty \\
\infty \\
\dot{0} \\
\stackrel{0}{0} \\
\stackrel{0}{0}\end{array}$ & $\begin{array}{l}\not \\
\infty \\
\infty \\
\infty \\
\infty \\
\infty\end{array}$ & $\begin{array}{l}\overrightarrow{0} \\
\overrightarrow{0} \\
\vec{\infty}\end{array}$ & 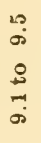 & 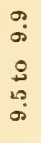 & $\begin{array}{l}\stackrel{\infty}{0} \\
\stackrel{0}{0} \\
\stackrel{\rho}{\circ} \\
\dot{\rho}\end{array}$ & $\begin{array}{l}5 \\
0 \\
0 \\
0 \\
\infty \\
0 \\
0\end{array}$ & 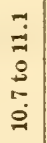 & 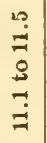 & 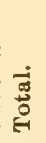 \\
\hline 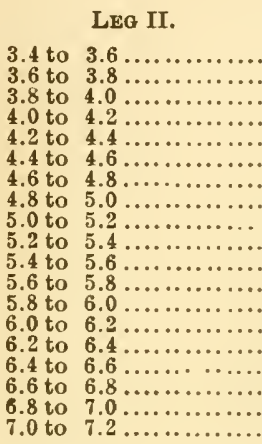 & 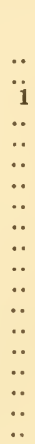 & $\begin{array}{l}\mathbf{1} \\
\mathbf{2} \\
\mathbf{1} \\
\mathbf{.} \\
\ddot{.} \\
\ddot{.} \\
\ddot{.} \\
.0 \\
\ddot{.} \\
. \\
\ddot{.} \\
. .\end{array}$ & $\begin{array}{c}3 \\
3 \\
3 \\
2 \\
1 \\
. \\
. \\
. . \\
. \\
. \\
. . \\
. \\
. . \\
. . \\
. . \\
. \\
. .\end{array}$ & 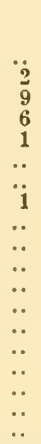 & 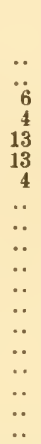 & 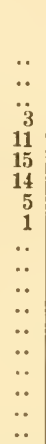 & 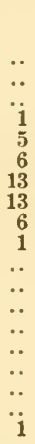 & 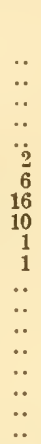 & $\begin{array}{c}\ddot{0} \\
\ddot{.} \\
\ddot{0} \\
\ddot{1} \\
\ddot{4} \\
7 \\
4 \\
3 \\
1 \\
\ddot{0} \\
\ddot{.} \\
\ddot{.}\end{array}$ & 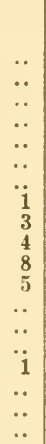 & $\begin{array}{l}\because . \\
\because . \\
. . \\
. . \\
. . \\
\ddot{2} \\
2 \\
2 \\
3 \\
2 \\
. \\
. \\
. . \\
. .\end{array}$ & 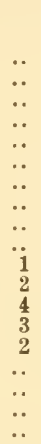 & 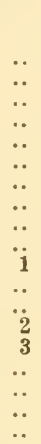 & 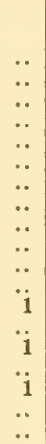 & 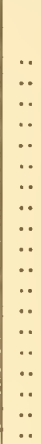 & 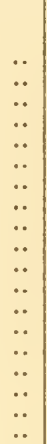 & 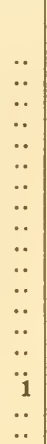 & $\begin{array}{r}4 \\
7 \\
20 \\
17 \\
31 \\
37 \\
37 \\
40 \\
27 \\
12 \\
16 \\
10 \\
8 \\
7 \\
6 \\
1 \\
2 \\
1\end{array}$ \\
\hline Total. .. & 1 & 5 & 12 & 19 & 40 & 49 & 46 & 36 & 20 & 22 & 11 & 12 & 6 & 3 & .. & .. & 1 & 283 \\
\hline 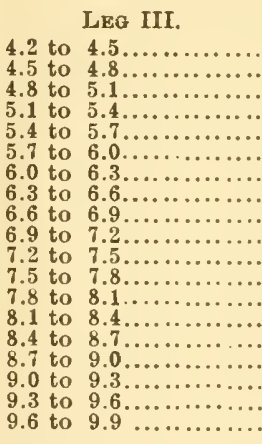 & 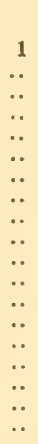 & $\begin{array}{l}1 \\
2 \\
1 \\
1 \\
. . \\
\because . \\
\because . \\
\because . \\
\because . \\
\because \because \\
\because . \\
\because .\end{array}$ & $\begin{array}{c}\ddot{3} \\
5 \\
3 \\
1 \\
. . \\
. . \\
. . \\
. . \\
. . \\
. . \\
. . \\
. . \\
. . \\
. .\end{array}$ & 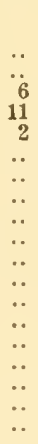 & $\begin{array}{r}. \ddot{0} \\
\ddot{1} \\
6 \\
19 \\
11 \\
2 \\
. .\end{array}$ & 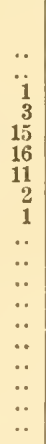 & 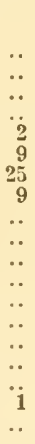 & 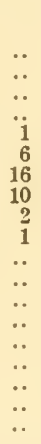 & 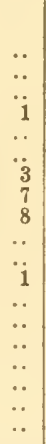 & $\begin{array}{l}. \ddot{ } \\
\ddot{.} \\
\ddot{.} \\
\ddot{1} \\
5 \\
7 \\
4 \\
4 \\
. . \\
\ddot{.} \\
\ddot{.} \\
\ddot{.} \\
\ddot{1}\end{array}$ & 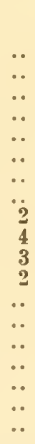 & 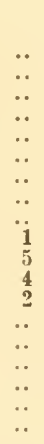 & 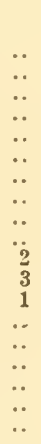 & 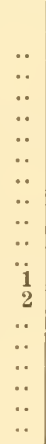 & $\begin{array}{l}. . \\
. \\
. . \\
. \\
. \\
. \\
. \\
. \\
. \\
. \\
. \\
. \\
. \\
.\end{array}$ & $\begin{array}{l}\ddot{.} \\
\ddot{.} \\
\ddot{.} \\
\ddot{.} \\
\ddot{.} \\
\ddot{.} \\
\ddot{.} \\
\ddot{.} \\
\ddot{.} \\
\ddot{.} \\
\ddot{.}\end{array}$ & $\begin{array}{l}. . \\
. . \\
. . \\
. . \\
. . \\
. \\
. \\
. . \\
. \\
. \\
\ddot{i} \\
. \\
. \\
. .\end{array}$ & $\begin{array}{r}2 \\
5 \\
14 \\
25 \\
40 \\
42 \\
58 \\
33 \\
20 \\
10 \\
14 \\
12 \\
5 \\
\ddot{1} \\
. . \\
\ddot{1} \\
1\end{array}$ \\
\hline Total............... & 1 & 5 & 12 & 19 & 40 & 49 & 46 & 36 & 20 & 22 & 11 & 12 & 6 & 3 & .. & .. & 1 & 283 \\
\hline
\end{tabular}


Table 28.-Continued.

\begin{tabular}{|c|c|c|c|c|c|c|c|c|c|c|c|c|c|c|c|c|c|c|}
\hline \multirow[b]{2}{*}{$\begin{array}{l}\text { LENGTh of } \\
\text { Propodite. }\end{array}$} & \multicolumn{18}{|c|}{ LENGTH OF CARPOPODITE, LEG I } \\
\hline & 18 & 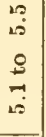 & 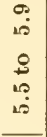 & $\mid \begin{array}{c}0 \\
0 \\
0 \\
0 \\
0 \\
0 \\
0\end{array}$ & $\begin{array}{l}= \\
0 \\
0 \\
0 \\
0 \\
0\end{array}$ & $\begin{array}{l}-1 \\
2= \\
0 \\
0 \\
0 \\
0\end{array}$ & 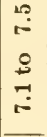 & 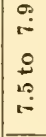 & $\left|\begin{array}{l}\infty \\
\infty \\
\infty \\
0 \\
0 \\
0 \\
i\end{array}\right|$ & $\mid \begin{array}{l}1 \\
\infty \\
\infty \\
\infty \\
\infty \\
\infty \\
\infty\end{array}$ & $\mid \begin{array}{l}-1 \\
0 \\
0 \\
1 \\
\infty\end{array}$ & $\mid \begin{array}{l}0 \\
0 \\
0 \\
0 \\
0 \\
0\end{array}$ & $\begin{array}{l}0 \\
0 \\
0 \\
\dot{0} \\
0 \\
0 \\
0\end{array}$ & $\begin{array}{l}\stackrel{0}{0} \\
\stackrel{0}{0} \\
\stackrel{0}{0} \\
0 \\
0\end{array}$ & $\begin{array}{l}10 \\
0 \\
0 \\
0 \\
0 \\
0 \\
0\end{array}$ & $\begin{array}{l}7 \\
3 \\
0 \\
8 \\
0 \\
0\end{array}$ & 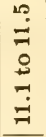 & 胥 \\
\hline $\begin{array}{l}\text { LEG I. } \\
12.1 \text { to } 13.1 \ldots \ldots \\
13.1 \text { to } 14.1 \ldots \ldots \\
14.1 \text { to } 15.1 \ldots \ldots \\
15.1 \text { to } 16.1 \ldots \ldots \\
16.1 \text { to } 17.1 \ldots \ldots \\
17.1 \text { to } 18.1 \ldots \ldots \\
18.1 \text { to } 19.1 \ldots \ldots \\
19.1 \text { to } 20.1 \ldots \ldots \\
20.1 \text { to } 21.1 \ldots \ldots \\
21.1 \text { to } 22.1 \ldots \ldots \\
22.1 \text { to } 23.1 \ldots \ldots \\
23.1 \text { to } 24.1 \ldots \ldots \\
24.1 \text { to } 25.1 \ldots \ldots \\
25.1 \text { to } 26.1 \ldots \ldots \\
26.1 \text { to } 27.1 \ldots \ldots \\
27.1 \text { to } 28.1 \ldots \ldots \\
28.1 \text { to } 29.1 \ldots \ldots \\
29.1 \text { to } 30.1 \ldots \ldots \\
30.1 \text { to } 31.1 \ldots \ldots \\
31.1 \text { to } 32.1 \ldots \ldots \\
32.1 \text { to } 33.1 \ldots \ldots \\
33.1 \text { to } 34.1 \ldots \ldots\end{array}$ & $\begin{array}{l}\ddot{ } \\
\ddot{ } \\
\ddot{ }\end{array}$ & $\begin{array}{c}1 \\
3 \\
1 \\
. . \\
. \\
. . \\
. . \\
. . \\
. \\
. . \\
. . \\
. . \\
. \\
. \\
. \\
. \\
. \\
. . \\
. .\end{array}$ & 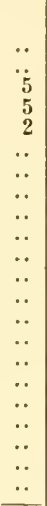 & 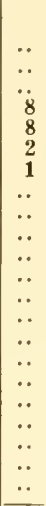 & 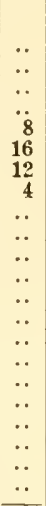 & 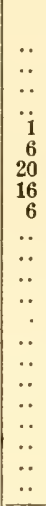 & 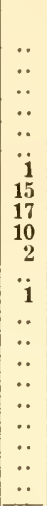 & 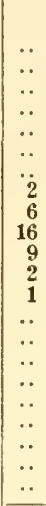 & 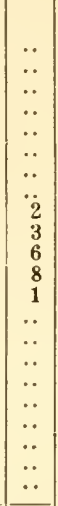 & 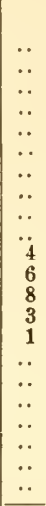 & 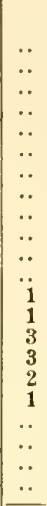 & $\begin{array}{l}\ddot{.} \\
\ddot{.} \\
\ddot{.} \\
\ddot{.} \\
\ddot{.} \\
\ddot{1} \\
\ddot{1} \\
5 \\
3 \\
. \\
\ddot{.} \\
\ddot{.}\end{array}$ & 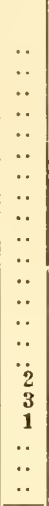 & 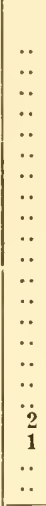 & $\begin{array}{l}. . \\
. . \\
. . \\
. . \\
. . \\
\end{array}$ & 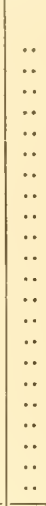 & 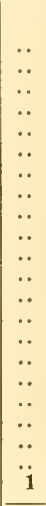 & $\begin{array}{l}6 \\
18 \\
19 \\
34 \\
3\end{array}$ \\
\hline Total....... & 1 & 5 & 12 & 19 & 40 & 49 & 46 & 36 & 20 & 22 & 11 & 12 & 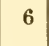 & & .. & .. & & 283 \\
\hline $\begin{array}{l}4.9 \text { to } 5.2 \ldots \ldots \\
5.2 \text { to } 5.5 \ldots \ldots \\
6.5 \text { to } 5.8 \ldots \ldots \\
5.8 \text { to } 6.1 \ldots \ldots \\
6.1 \text { to } 6.4 \ldots \ldots \\
6.4 \text { to } 6.7 \ldots \ldots \\
6.7 \text { to } 7.0 \ldots \ldots \\
7.0 \text { to } 7.3 \ldots \ldots \\
7.3 \text { to } 7.6 \ldots \ldots \\
7.6 \text { to } 7.9 \ldots \ldots \\
7.9 \text { to } 8.2 \ldots \ldots \\
8.2 \text { to } 8.5 \ldots \ldots \\
8.5 \text { to } 8.8 \ldots \ldots \\
8.8 \text { to } 9.1 \ldots \ldots . \\
9.1 \text { to } 9.4 \ldots \ldots \\
9.4 \text { to } 9.7 \ldots \ldots \\
9.7 \text { to } 10.0 \ldots \ldots \\
10.0 \text { to } 10.3 \ldots \ldots\end{array}$ & 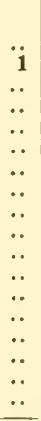 & $\begin{array}{l}1 \\
2 \\
2 \\
. \\
. . \\
. \\
. . \\
. . \\
. . \\
. . \\
. . \\
. . \\
. . \\
. .\end{array}$ & $\begin{array}{c}\ddot{2} \\
6 \\
3 \\
1 \\
. . \\
\ddot{.} \\
\ddot{.} \\
\ddot{.} \\
\ddot{.} \\
\ddot{.} \\
\ddot{.} \\
\ddot{.} \\
.\end{array}$ & 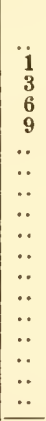 & $\begin{array}{l}\ddot{0} \\
\ddot{4} \\
12 \\
18 \\
6 \\
\ddot{0} \\
\ddot{0} \\
\ddot{0} \\
\ddot{0} \\
\ddot{~} \\
\ddot{.}\end{array}$ & $\begin{array}{r}\ddot{.} \\
\ddot{1} \\
1 \\
19 \\
20 \\
6 \\
1 \\
1 \\
. \\
\ddot{.} \\
\ddot{.} \\
\ddot{.} \\
. .\end{array}$ & $\begin{array}{r}\ddot{.} \\
\ddot{1} \\
6 \\
6 \\
16 \\
18 \\
4 \\
1 \\
. . \\
\because . \\
\because . \\
\because . \\
\ddot{.} \\
. \\
\end{array}$ & $\begin{array}{r}\ddot{.} \\
\ddot{.} \\
\ddot{1} \\
3 \\
16 \\
11 \\
4 \\
1 \\
. \\
\ddot{0} \\
\ddot{.} \\
\ddot{.} \\
.\end{array}$ & 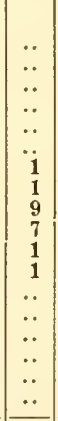 & $\begin{array}{l}\ddot{.} \\
\ddot{.} \\
\ddot{.} \\
\ddot{5} \\
9 \\
7 \\
\ddot{0} \\
\ddot{1} \\
\ddot{.} \\
\ddot{.}\end{array}$ & $\begin{array}{l}\ddot{.} \\
\ddot{.} \\
\ddot{.} \\
\ddot{.} \\
\ddot{.} \\
\ddot{2} \\
\ddot{5} \\
4 \\
\ddot{0} \\
\ddot{0} \\
\ddot{.}\end{array}$ & 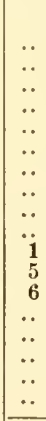 & $\begin{array}{l}\ddot{.} \\
\ddot{.} \\
\ddot{.} \\
\ddot{.} \\
\ddot{.} \\
\ddot{1} \\
1 \\
4 \\
\ddot{.} \\
\ddot{.}\end{array}$ & $\begin{array}{l}\ddot{.} \\
\ddot{.} \\
\ddot{~} \\
\ddot{~} \\
\ddot{0} \\
\ddot{~} \\
\ddot{~} \\
\ddot{2} \\
. \\
.\end{array}$ & 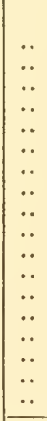 & $\begin{array}{l}\ddot{.} \\
\ddot{.} \\
. \\
. \\
. \\
. \\
. \\
. \\
. \\
. \\
. \\
.\end{array}$ & $\begin{array}{l}\ddot{.} \\
\ddot{.} \\
\ddot{.} \\
\ddot{.} \\
\ddot{.} \\
\ddot{0} \\
\ddot{0} \\
\ddot{0} \\
\ddot{~}\end{array}$ & $\begin{array}{l}1 \\
1 \\
2 \\
4 \\
4 \\
4 \\
3 \\
2 \\
1\end{array}$ \\
\hline Total... & 1 & 5 & 12 & 19 & 40 & 49 & 46 & 36 & 20 & 22 & 11 & 12 & 6 & : & .. & .. & 1 & 285 \\
\hline $\begin{array}{r}6.6 \text { to } 7.0 \\
7.0 \text { to } 7.4 \\
7.4 \text { to } 7.8 \\
7.8 \text { to } 8.2 \\
8.2 \text { to } 8 . \\
8.6 \text { to } 9 . \\
9.0 \text { to } 9 . \\
9.4 \text { to } 9 . \\
9.8 \text { to } 10 . \\
10.2 \text { to } 10 . \\
10.6 \text { to } 11 . \\
11.0 \text { to } 11 . \\
11.4 \text { to } 11 . \\
11.8 \text { to } 12 . \\
12.2 \text { to } 12 . \\
12.6 \text { to } 13 .\end{array}$ & $\ddot{.}$ & 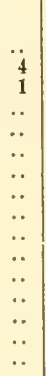 & 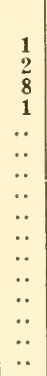 & $\begin{array}{r}\ddot{4} \\
4 \\
11 \\
\ddot{.} \\
\ddot{.} \\
\ddot{.} \\
\ddot{.} \\
\ddot{.} \\
\ddot{.} \\
\ddot{.} \\
\ddot{.}\end{array}$ & 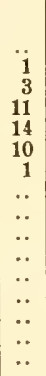 & 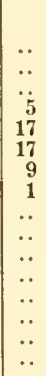 & 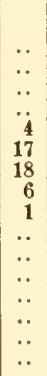 & $\begin{array}{r}\ddot{y} \\
\ddot{~} \\
\ddot{3} \\
3 \\
14 \\
15 \\
1\end{array}$ & $\begin{array}{c}\ddot{y} \\
\ddot{y} \\
\ddot{1} \\
3 \\
8 \\
5 \\
2 \\
1 \\
\ddot{y} \\
\ddot{.} \\
\ddot{.}\end{array}$ & 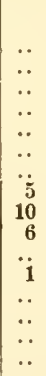 & $\begin{array}{l}\because . \\
\because . \\
\because . \\
\because . \\
\because . \\
\because \\
\ddot{4} \\
5 \\
2 \\
. . \\
. . \\
. .\end{array}$ & 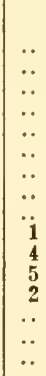 & 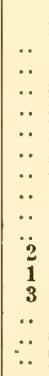 & $\begin{array}{l}\because . \\
\because . \\
\because . \\
\because \\
\because \\
\because \\
\because \\
\ddot{1} \\
2 \\
\because \\
\because\end{array}$ & $\begin{array}{l}. . \\
. . \\
. . . \\
. . \\
. . \\
. . \\
. . \\
. . \\
. . \\
. .\end{array}$ & $\begin{array}{l}. . \\
\ddot{.} \\
\ddot{.}\end{array}$ & 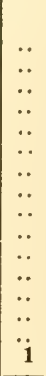 & $\begin{array}{l}1 \\
1 \\
2 \\
3 \\
4 \\
4 \\
3 \\
1 \\
1 \\
1\end{array}$ \\
\hline Total....... & 1 & 5 & 12 & 19 & 40 & 49 & 46 & 36 & 20 & 22 & 11 & 12 & 6 & 3 & $\cdot \cdot$ & .. & 1 & 283 \\
\hline
\end{tabular}


TABLES OF MEASUREMENTS.

TABLE 29.

\begin{tabular}{|c|c|c|c|c|c|c|c|c|c|c|c|c|c|c|c|c|c|c|c|c|}
\hline \multirow[b]{2}{*}{$\begin{array}{l}\text { LENGTH of } \\
\text { Propodite. }\end{array}$} & \multicolumn{20}{|c|}{ LENGTH OF CARPOPODITE, LEG II. } \\
\hline & 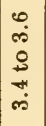 & $\begin{array}{l}\infty \\
\infty \\
\infty \\
\stackrel{0}{0} \\
0 \\
\infty\end{array}$ & $\begin{array}{l}0 \\
\dot{+} \\
\dot{0} \\
\infty \\
\infty \\
\infty\end{array}$ & 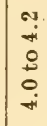 & 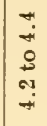 & 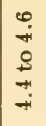 & $\begin{array}{l}\infty \\
\stackrel{0}{+} \\
\stackrel{8}{8} \\
\stackrel{0}{+}\end{array}$ & $\begin{array}{l}0 \\
10 \\
0 \\
\infty \\
\infty \\
\infty \\
+i\end{array}$ & $\mid \begin{array}{c}0 \\
0 \\
10 \\
0 \\
0 \\
0 \\
10 \\
\end{array}$ & $\mid \begin{array}{l}7 \\
10 \\
0 \\
0 \\
01 \\
20\end{array}$ & मे & \begin{tabular}{|c|c}
$\infty$ \\
20 \\
0 \\
$\vdots$ \\
0 \\
0. \\
10
\end{tabular} & $\begin{array}{l}0 \\
0 \\
0 \\
0 \\
\infty \\
10 \\
10\end{array}$ & $\mid \begin{array}{l}0 \\
0 \\
0 \\
0 \\
0 \\
0 \\
0\end{array}$ & $\begin{array}{l}+ \\
0 \\
0 \\
0 \\
0 ! \\
0 \\
0\end{array}$ & 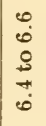 & $\begin{array}{l}\infty \\
0 \\
0 \\
\vdots \\
0 \\
0 \\
0\end{array}$ & 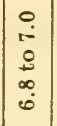 & $\begin{array}{l}? \\
? \\
\vdots \\
\vdots \\
0 \\
0\end{array}$ & 苛 \\
\hline 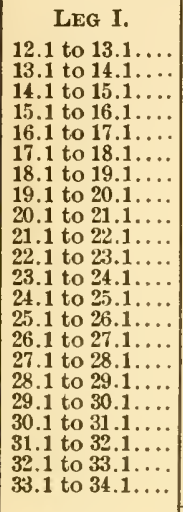 & 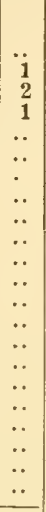 & $\begin{array}{c}\mathbf{1} \\
\mathbf{1} \\
\mathbf{1} \\
3 \\
\mathbf{1} \\
. . \\
\because . \\
\because . \\
. \\
\because \\
\because . \\
\because . \\
\because . \\
\because . \\
\because \\
\because \\
\because . \\
\end{array}$ & $\begin{array}{c}\ddot{1} \\
2 \\
4 \\
7 \\
4 \\
2 \\
. . \\
\because . \\
\because . \\
\because . \\
\because . \\
\because . \\
\because . \\
\because . \\
\because . \\
\because . \\
\because .\end{array}$ & 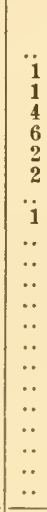 & $\begin{array}{r}\because . \\
\because . \\
\ddot{5} \\
5 \\
8 \\
11 \\
2 \\
\because \\
\because \\
\because \\
\because \\
\because \\
\because \\
\because \\
\because \\
\because \\
\because \\
\end{array}$ & 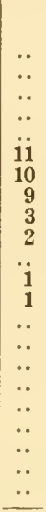 & $\begin{array}{r}. . \\
. . \\
\ddot{.} \\
\ddot{1} \\
9 \\
11 \\
9 \\
6 \\
\ddot{1} \\
. \\
. \\
. \\
. \\
. \\
. \\
. \\
. \cdot\end{array}$ & 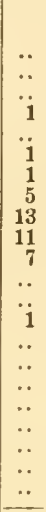 & 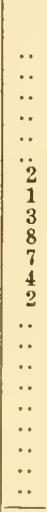 & 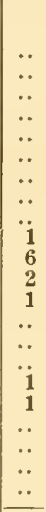 & $\begin{array}{l}\ddot{.} \\
\ddot{1} \\
6 \\
5 \\
2 \\
1\end{array}$ & 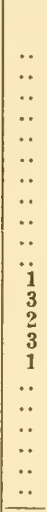 & $\begin{array}{l}\because . . \\
\because . . \\
\because . . \\
\because . . \\
\because . . \\
\because . \\
\because . \\
\because . \\
\ddot{3} \\
2 \\
2 \\
\because . \\
\ddot{1} \\
\because . \\
\end{array}$ & $\begin{array}{l}\because . \\
\because . \\
\because . . \\
\because . \\
\because . \\
\because . \\
. \\
\because . \\
\ddot{2} \\
2 \\
1 \\
1 \\
. .\end{array}$ & 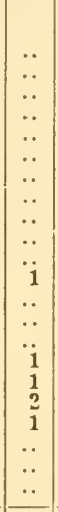 & 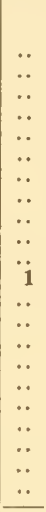 & 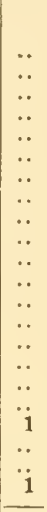 & 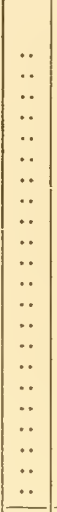 & 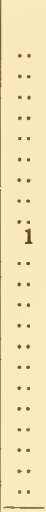 & $\begin{array}{r}1 \\
4 \\
6 \\
13 \\
19\end{array}$ \\
\hline Total....... & 4 & 7 & 20 & 17 & & 37 & 37 & 40 & 27 & 12 & 16 & 10 & 8 & 7 & 6 & 1 & 2 & .. & 1 & 283 \\
\hline $\begin{array}{l}4.9 \text { to } \\
5.2 \text { to } \\
5.5 \text { to } \\
5.8 \text { to } \\
6.1 \text { to } \\
6.4 \text { to } \\
6.7 \text { to } \\
7.0 \text { to } \\
7.3 \text { to } \\
7.6 \text { to } \\
7.9 \text { to } \\
8.2 \text { to } \\
8.5 \text { to } \\
8.8 \text { to } \\
9.1 \text { to } \\
9.4 \text { to } \\
9.5\end{array}$ & $\begin{array}{c}\ddot{1} \\
3 \\
. \\
\ddot{.} \\
\ddot{.} \\
\ddot{.} \\
\ddot{.} \\
\ddot{.} \\
\ddot{.} \\
\ddot{.} \\
\ddot{.}\end{array}$ & $\begin{array}{c}1 \\
2 \\
3 \\
.1 \\
. \\
. \\
. \\
\ddot{.} \\
. \\
\ddot{.} \\
. \\
. \\
. \\
. \\
. .\end{array}$ & $\begin{array}{c}\ddot{2} \\
2 \\
7 \\
7 \\
2 \\
. . \\
\because . \\
\because . \\
\because . \\
\because . \\
\because . \\
\ddot{.} \\
\ddot{.} \\
. .\end{array}$ & 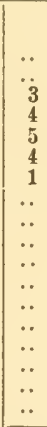 & $\begin{array}{c}\ddot{.} \\
\ddot{3} \\
9 \\
12 \\
6 \\
1 \\
. \\
\because \\
\ddot{.} \\
\ddot{.} \\
\ddot{.} \\
\ddot{.}\end{array}$ & $\begin{array}{c}\ddot{.} \\
\ddot{2} \\
17 \\
13 \\
13 \\
3 \\
\ddot{2} \\
\ddot{.} \\
\ddot{.} \\
\ddot{.} \\
\ddot{.} \\
. .\end{array}$ & $\begin{array}{r}\ddot{.} \\
\ddot{.} \\
\ddot{8} \\
16 \\
10 \\
2 \\
1 \\
. . \\
\ddot{.} \\
\ddot{.} \\
\ddot{.} \\
. .\end{array}$ & $\begin{array}{c}\ddot{1} \\
. \\
\ddot{1} \\
\ddot{1} \\
20 \\
7 \\
2 \\
1 \\
\ddot{.} \\
\ddot{.} \\
\ddot{.} \\
.\end{array}$ & 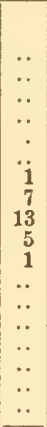 & $\begin{array}{l}\ddot{.} \\
\ddot{.} \\
\ddot{.} \\
\ddot{.} \\
\ddot{8} \\
1 \\
2 \\
\ddot{1} \\
. \\
\ddot{.} \\
\ddot{.} \\
. .\end{array}$ & $\begin{array}{l}\ddot{.} \\
\ddot{.} \\
\ddot{.} \\
\ddot{.} \\
\ddot{7} \\
6 \\
2 \\
\ddot{1} \\
. .\end{array}$ & 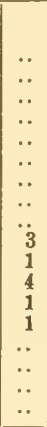 & $\begin{array}{c}\ddot{.} \\
\ddot{.} \\
\ddot{.} \\
\ddot{.} \\
\ddot{.} \\
\ddot{.} \\
\ddot{1} \\
3 \\
3 \\
\ddot{1} \\
. \\
\ddot{.} \\
. .\end{array}$ & $\begin{array}{l}\because . . \\
. . \\
\because . \\
\because . \\
\because . \\
\because . \\
\ddot{3} \\
\ddot{3} \\
3 \\
1 \\
. . \\
. . \\
. .\end{array}$ & 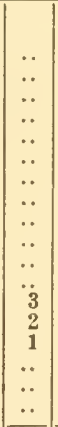 & $\begin{array}{l}\ddot{.} \\
\ddot{.} \\
\ddot{.} \\
\ddot{.} \\
\ddot{\mathrm{i}} \\
\ddot{.} \\
\ddot{.} \\
\ddot{.} \\
\ddot{.} \\
. .\end{array}$ & $\begin{array}{l}\ddot{.} \\
\ddot{.} \\
\ddot{.} \\
\ddot{.} \\
\ddot{.} \\
\ddot{.} \\
\ddot{.} \\
\ddot{.} \\
\ddot{\mathrm{i}} \\
\ddot{\mathrm{i}}\end{array}$ & 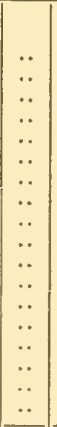 & $\begin{array}{l}\ddot{.} \\
\ddot{.} \\
\ddot{.} \\
\ddot{i} \\
. . \\
\ddot{.} \\
\ddot{.} \\
\ddot{.} \\
\ddot{.} \\
\ddot{.}\end{array}$ & $\begin{array}{r}1 \\
6 \\
11 \\
14 \\
24 \\
44 \\
46 \\
41 \\
30 \\
22 \\
12 \\
12 \\
11 \\
5 \\
1 \\
1\end{array}$ \\
\hline Total...... & 4 & 7 & 20 & 17 & 31 & 37 & 37 & 40 & 27 & 12 & 16 & 10 & 8 & 7 & 6 & 1 & 2 & .. & 1 & 283 \\
\hline $\begin{array}{r}7.4 \text { to } 7.8 \ldots \ldots \\
7.8 \text { to } 8.2 \ldots \\
8.2 \text { to } 8.6 \ldots \\
8.6 \text { to } 9.0 \ldots \\
9.0 \text { to } 9.4 \ldots \\
9.4 \text { to } 9.8 \ldots \\
9.8 \text { to } 10.2 \ldots \\
10.2 \text { to } 10.6 \ldots \\
10.6 \text { to } 11.0 \ldots \\
11.0 \text { to } 11.4 \ldots \\
11.4 \text { to } 11.8 \ldots \\
11.8 \text { to } 12.2 \ldots \\
12.2 \text { to } 12.6 \ldots \\
12.6 \text { to } 13.0 \ldots\end{array}$ & 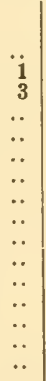 & 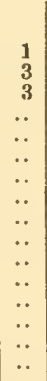 & $\begin{array}{l}\ddot{6} \\
4 \\
7 \\
3 \\
\ddot{.} \\
\because . \\
\because . \\
\because . \\
\because . \\
\ddot{.} \\
\ddot{.} \\
\ddot{.}\end{array}$ & $\begin{array}{l}\ddot{1} \\
\ddot{~} \\
\ddot{~} \\
\ddot{0} \\
\ddot{0} \\
\ddot{.}\end{array}$ & $\begin{array}{r}1 \\
2 \\
7 \\
13 \\
6 \\
1 \\
\because \\
1 \\
\because \\
\because \\
\because \\
\because \\
\because \\
\because\end{array}$ & $\begin{array}{r}\ddot{.} \\
\ddot{5} \\
11 \\
16 \\
3 \\
2 \\
\because \\
\because \\
\because \\
\because \\
\because \\
\because \\
\because \\
\end{array}$ & $\begin{array}{l}\ddot{.} \\
\ddot{5} \\
15 \\
13 \\
3 \\
1 \\
. \\
\ddot{.} \\
\ddot{.} \\
\ddot{.}\end{array}$ & $\begin{array}{c}\ddot{1} \\
\ddot{2} \\
8 \\
18 \\
10 \\
\ddot{1} \\
\ddot{.} \\
\ddot{.} \\
\ddot{.}\end{array}$ & $\begin{array}{r}\because . . \\
\because \\
\ddot{1} \\
3 \\
6 \\
12 \\
4 \\
1 \\
\because . \\
\because . \\
\because . \\
\because . . \\
. .\end{array}$ & $\begin{array}{l}\ddot{.} \\
\ddot{.} \\
\ddot{.} \\
\ddot{1} \\
7 \\
2 \\
1 \\
\ddot{i} \\
\ddot{.} \\
\ddot{.}\end{array}$ & $\begin{array}{c}\ddot{\because} \\
\ddot{0} \\
\ddot{0} \\
\ddot{1} \\
1 \\
5 \\
8 \\
1 \\
\ddot{y}\end{array}$ & $\begin{array}{l}\ddot{.} \\
\ddot{.} \\
\ddot{.} \\
\ddot{.} \\
\ddot{3} \\
2 \\
3 \\
2 \\
\ddot{.} \\
\ddot{.} \\
. .\end{array}$ & $\begin{array}{l}\ddot{.} \\
\ddot{.} \\
\because \\
\ddot{.} \\
\ddot{.} \\
\ddot{3} \\
3 \\
3 \\
2 \\
. \\
\because \\
. .\end{array}$ & $\begin{array}{l}\ddot{.} \\
\ddot{.} \\
\ddot{.} \\
\ddot{.} \\
\ddot{.} \\
\ddot{4} \\
2 \\
1 \\
\ddot{.} \\
\therefore\end{array}$ & 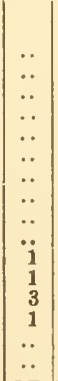 & $\begin{array}{l}\ddot{.} \\
\ddot{.} \\
\ddot{.} \\
\ddot{.} \\
. \\
\ddot{.} \\
\ddot{.} \\
\ddot{.} \\
.\end{array}$ & $\begin{array}{l}\ddot{.} \\
\ddot{.} \\
\ddot{.} \\
\ddot{.} \\
\ddot{.} \\
\ddot{.} \\
\ddot{i} \\
\ddot{i}\end{array}$ & 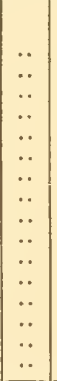 & $\begin{array}{l}\ddot{.} \\
\ddot{.} \\
\ddot{.} \\
. . \\
\ddot{.} \\
\ddot{.} \\
\ddot{.} \\
\ddot{.} \\
.\end{array}$ & $\begin{array}{r}1 \\
12 \\
16 \\
28 \\
38 \\
48 \\
45 \\
35 \\
17 \\
13 \\
12 \\
9 \\
6 \\
2\end{array}$ \\
\hline Total...... & 4 & 7 & 20 & 17 & 31 & 37 & 37 & 40 & 27 & 12 & 16 & 10 & 8 & 1 & 6 & 1 & 2 &. & 1 & 283 \\
\hline
\end{tabular}


TABle 29.-Continued.

\begin{tabular}{|c|c|c|c|c|c|c|c|c|c|c|c|c|c|c|c|c|c|c|c|c|}
\hline \multirow[b]{2}{*}{$\begin{array}{c}\text { LENGTH OF } \\
\text { CARPOPODITE. }\end{array}$} & \multicolumn{20}{|c|}{ Length of Carpopodite, Leg il. } \\
\hline & 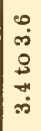 & $\begin{array}{l}\infty \\
\text { o } \\
0 \\
0 \\
0 \\
\infty\end{array}$ & $\begin{array}{l}\stackrel{0}{+} \\
\stackrel{\$}{\infty} \\
\infty \\
\text { of }\end{array}$ & 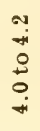 & 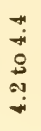 & 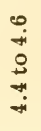 & $\begin{array}{l}\infty \\
\stackrel{\infty}{+} \\
\stackrel{8}{+} \\
\stackrel{0}{+} \\
-i\end{array}$ & 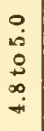 & 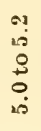 & $\begin{array}{l}\vec{j} \\
\dot{0} \\
0 \\
\text { on } \\
i \dot{0}\end{array}$ & 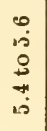 & $\mid \begin{array}{l}\infty \\
0 \\
0 \\
\rho \\
0 \\
0 \\
0\end{array}$ & 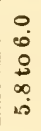 & $\begin{array}{l}\stackrel{1}{0} \\
0 \\
0 \\
+ \\
0 \\
0\end{array}$ & $\begin{array}{l}+ \\
0 \\
0 \\
\vdots \\
\vdots \\
0 \\
0\end{array}$ & 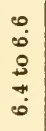 & $\begin{array}{l}\infty \\
\dot{0} \\
0 \\
0 \\
0 \\
0 \\
0\end{array}$ & $\begin{array}{l}0 \\
0 \\
0 \\
\infty \\
0 \\
0\end{array}$ & 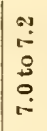 & 㷰 \\
\hline $\begin{array}{r}\text { L } \\
4.2 \\
4.5 \\
4.8 \\
5.1 \\
5.4 \\
5.7 \\
6.0\end{array}$ & $\begin{array}{l}\ddot{3} \\
\because \\
\because \\
\because \\
\because \\
\because \\
\because \\
\because \\
\because \\
\because \\
\because \\
\because \\
\end{array}$ & $\begin{array}{l}3 \\
3 \\
1 \\
. \\
\because \\
\because \\
\because \\
\because \\
\because \\
\because \\
\because \\
\because \\
\because \\
\because . \\
.\end{array}$ & $\begin{array}{c}1 \\
2 \\
3 \\
9 \\
4 \\
1 \\
. \because \\
\because \\
\therefore \\
\because \\
\because \\
\because \\
\because \\
\because \\
\because \\
\because \\
\therefore\end{array}$ & 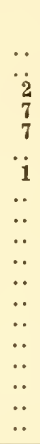 & $\begin{array}{r}\because \ddot{1} \\
\ddot{1} \\
13 \\
8 \\
3 \\
\ddot{0} \\
\ddot{0} \\
\ddot{1} \\
.\end{array}$ & $\begin{array}{r}. . \\
\ddot{1} \\
1 \\
12 \\
14 \\
6 \\
2 \\
1 \\
. . \\
. . \\
\because . . \\
\because . . \\
\because . \\
. .\end{array}$ & 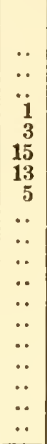 & 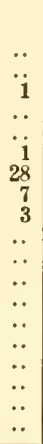 & $\begin{array}{r}\because . \\
\because \ddot{1} \\
1 \\
3 \\
6 \\
12 \\
3 \\
1 \\
. . \\
\because . \\
\because . \\
\because . \\
\because .\end{array}$ & $\begin{array}{c}.0 \\
\ddot{.} \\
\ddot{.} \\
\ddot{.} \\
\ddot{4} \\
7 \\
\ddot{1} \\
. . \\
\ddot{.} \\
\ddot{.} \\
\ddot{.} \\
. .\end{array}$ & $\begin{array}{c}. . \\
\ddot{.} \\
\ddot{.} \\
\ddot{.} \\
\ddot{2} \\
\ddot{2} \\
6 \\
3 \\
5 \\
\ddot{.} \\
\ddot{.} \\
\ddot{.} \\
\ddot{.} \\
\ddot{.}\end{array}$ & 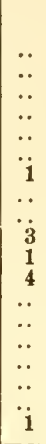 & $\begin{array}{l}\because . \\
. . \\
. . \\
. . \\
. . \\
. . \\
\ddot{2} \\
3 \\
3 \\
. . \\
. . \\
. . \\
. .\end{array}$ & $\begin{array}{c}. . \\
\ddot{.} \\
\ddot{.} \\
\ddot{.} \\
\ddot{.} \\
\ddot{y} \\
\ddot{1} \\
2 \\
2 \\
2 \\
\ddot{.} \\
\ddot{.} \\
\ddot{.} \\
. .\end{array}$ & 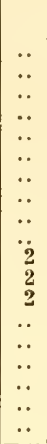 & 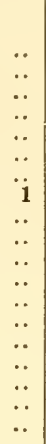 & 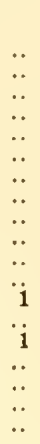 & $\begin{array}{l}. . \\
\ddot{.} \\
\ddot{.} \\
\ddot{.} \\
\ddot{.} \\
\ddot{.} \\
\ddot{.} \\
\ddot{.} \\
\ddot{.} \\
\ddot{.} \\
\ddot{.} \\
\ddot{.}\end{array}$ & 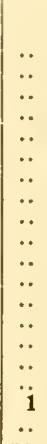 & $\begin{array}{l}1 \\
2 \\
4 \\
4 \\
5 \\
3 \\
3 \\
20 \\
10 \\
10\end{array}$ \\
\hline Total.. & 4 & 7 & 20 & 17 & 31 & 37 & 37 & 40 & 27 & 12 & 16 & 10 & 8 & 7 & 6 & 1 & 2 &.. & 1 & 283 \\
\hline
\end{tabular}


TABLES OF MEASUREMENTS.

Table 30.

\begin{tabular}{|c|c|c|c|c|c|c|c|c|c|c|c|c|c|c|c|c|c|c|c|c|}
\hline \multirow[b]{2}{*}{$\begin{array}{l}\text { LENGTH of } \\
\text { PROPODITE. }\end{array}$} & \multicolumn{20}{|c|}{ LENGth of Carpopodite, Leg iII. } \\
\hline & 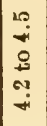 & 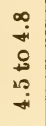 & $\begin{array}{l}\overrightarrow{1} \\
\dot{10} \\
+ \\
\infty \\
+ \\
+\end{array}$ & $\begin{array}{l}4 \\
20 \\
0 \\
0 \\
20 \\
20\end{array}$ & 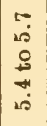 & $\begin{array}{l}0 \\
0 \\
0 \\
1 \\
10 \\
0\end{array}$ & $\begin{array}{l}\infty \\
0 \\
0 \\
0 \\
0 \\
0 \\
0\end{array}$ & $\mid$\begin{tabular}{l|}
0 \\
$\dot{0}$ \\
0 \\
0 \\
0 \\
0
\end{tabular} & $\begin{array}{l}0 \\
\dot{0} \\
0 \\
0 \\
0 \\
0\end{array}$ & 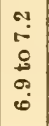 & 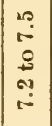 & 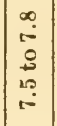 & \begin{tabular}{l}
$\overrightarrow{1}$ \\
$\infty$ \\
0 \\
$\dot{0}$ \\
$\infty$ \\
\hdashline
\end{tabular} & $\begin{array}{c}+ \\
\infty \\
\infty \\
0 \\
+1 \\
\infty \\
\infty\end{array}$ & $\begin{array}{l}5 \\
\infty \\
0 \\
\vdots \\
-1 \\
\infty\end{array}$ & $\begin{array}{l}0 \\
0 \\
0 \\
\infty \\
\infty \\
\infty\end{array}$ & 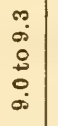 & $\begin{array}{l}\dot{0} \\
\dot{0} \\
\dot{8} \\
\dot{m} \\
\infty\end{array}$ & \begin{tabular}{c|c}
0 \\
$\dot{0}$ \\
0 \\
$\dot{0}$ \\
$\dot{0}$ \\
$\dot{0}$
\end{tabular} & 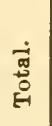 \\
\hline 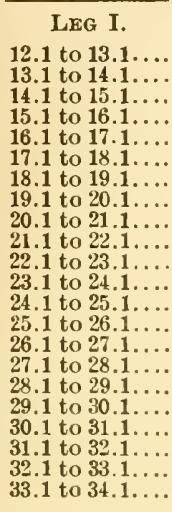 & $\begin{array}{r}2 \\
\because \\
\because \\
\because \\
\because \\
\because \\
\because \\
\because \\
\because \\
\because \\
\because \\
\because \\
\because \\
\because \\
\because \\
\end{array}$ & 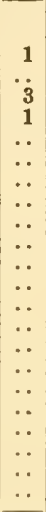 & $\begin{array}{c}1 \\
2 \\
6 \\
3 \\
1 \\
\because 1 \\
\because \\
\because \\
\because \\
\because \\
\because \\
\because \\
\because \\
\because \\
\because \\
\because \\
\end{array}$ & 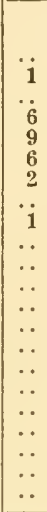 & $\begin{array}{c}\because \\
\mathbf{i} \\
\ddot{6} \\
11 \\
13 \\
8 \\
\because \\
\because \mathbf{i} \\
\because \\
\because \\
\because \\
\because \\
\because \\
\because \\
\because\end{array}$ & 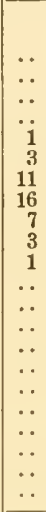 & $\begin{array}{c}\because \\
\because \\
\because \\
\because 2 \\
2 \\
4 \\
10 \\
20 \\
14 \\
2 \\
3 \\
3 \\
\because \\
\because \\
\because \\
\because \\
\because \\
\because . \\
\end{array}$ & 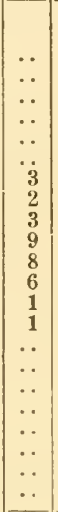 & \begin{tabular}{|c|c|}
$\because$ \\
$\because$ \\
$\because$ \\
$\because$ \\
$\because$ \\
$\because$ \\
$\because$ \\
2 \\
8 \\
4 \\
4 \\
$\because$ \\
$\because$ \\
$\because$ \\
1 \\
$\because$ \\
$\because$ \\
$\because$ \\
\end{tabular} & \begin{tabular}{|c|}
$\because$ \\
$\because$ \\
$\because$ \\
$\because$ \\
$\because$ \\
$\because$ \\
$\because$ \\
$\because$ \\
1 \\
2 \\
2 \\
1 \\
3 \\
$\because$ \\
$\because$ \\
$\because$ \\
$\because$ \\
\end{tabular} & \begin{tabular}{|c|}
$\because$ \\
$\because$. \\
$\because$. \\
$\because$. \\
$\because$ \\
$\because$ \\
$\because$ \\
$\because$ \\
$\because$ \\
1 \\
$\frac{1}{2}$ \\
3 \\
2 \\
5 \\
$\because$. \\
$\because$ \\
$\because$. \\
\end{tabular} & 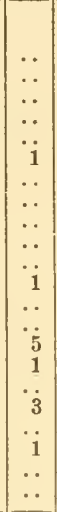 & $\begin{array}{c}\because \because \\
\because \\
\because \\
\because \\
\because \\
\because \\
\because \\
\because \\
\ddot{1} \\
\because \\
\because \\
\because \\
1 \\
\ddot{3} \\
\because \\
\because . \\
\end{array}$ & $\begin{array}{c}. \\
. \\
. \\
\because \\
. \\
. \\
\because \\
\because \\
\because \\
\because \\
\because \\
\because \\
\because \\
\because \\
\because \\
\because \\
\because \\
.\end{array}$ & 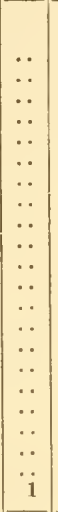 & 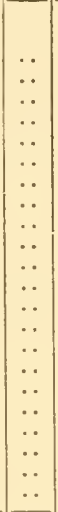 & 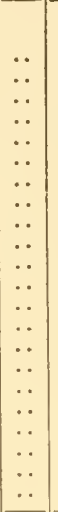 & $\begin{array}{c}\because \\
\because \\
\because \\
\because \\
\because \\
\because \\
\because \mathrm{i} \\
\because \\
\because \\
\because \\
\because \\
\because \\
\because \\
\because \\
\because \\
\end{array}$ & \begin{tabular}{|c|}
$\because$ \\
$\because$ \\
$\because$ \\
$\because$ \\
$\because$ \\
$\because$ \\
$\because$ \\
$\because$ \\
$\because$ \\
$\because$ \\
$\therefore$ \\
$\because \because$ \\
$\because \because$ \\
$\because$ \\
$\because$ \\
$\because \because$ \\
\end{tabular} & $\begin{array}{r}1 \\
4 \\
6 \\
13 \\
19 \\
24 \\
34\end{array}$ \\
\hline Total..... & 2 & 5 & $\overline{14}$ & 25 & 40 & 42 & $\overline{58}$ & 33 & 20 & 70 & 14 & $\overline{12}$ & &.. & 1 & .. &.. & & 1 & 283 \\
\hline $\begin{array}{r}\text { L } \\
4.9 \mathrm{t} \\
5.2 \mathrm{t} \\
5.5 \mathrm{t} \\
5.8 \mathrm{t} \\
6.1 \mathrm{t} \\
6.4 \\
6.7 \mathrm{t} \\
7.0 \mathrm{t} \\
7.3 \mathrm{t} \\
7.6 \mathrm{t} \\
7.9 \mathrm{t} \\
8.25 \\
8.5 \mathrm{t} \\
8.8 \mathrm{t} \\
9.1 \mathrm{t} \\
9.4 \mathrm{t} \\
9\end{array}$ & $\begin{array}{l}\ddot{2} \\
\because \\
\because \\
\because . \\
\because \\
\because \\
\because \\
\because \\
\because \\
\because \\
\because \\
\because \\
\because \\
\end{array}$ & $\begin{array}{c}\ddot{2} \\
3 \\
\because . \\
\because \\
\because \\
\because \\
\because \\
\because \\
\because \\
\because \\
\because \\
\because \\
\because \\
\because \\
\end{array}$ & $\begin{array}{c}1 \\
1 \\
4 \\
4 \\
3 \\
1 \\
\because \\
\because \\
\because \\
\because \\
\because \\
\because \\
\because \\
\because \\
\therefore\end{array}$ & $\begin{array}{l}\mathrm{i} \\
\because \\
\because \\
\because \\
\because \\
\because \\
\because\end{array}$ & $\begin{array}{r}\because \\
\ddot{i} \\
4 \\
8 \\
17 \\
9 \\
\ddot{i} \\
\because \\
\because \\
\because \\
\because \\
\because \\
\because\end{array}$ & $\begin{array}{c}\because \\
\because \because \\
\because \\
4 \\
15 \\
16 \\
5 \\
2 \\
. \\
\because . \\
\because \\
\because \\
\because \\
\because \\
\therefore\end{array}$ & \begin{tabular}{|r}
$\because$. \\
$\because$. \\
$\because$ \\
07 \\
17 \\
25 \\
4 \\
4 \\
1 \\
$\because$ \\
$\because$ \\
$\because$ \\
$\because$ \\
$\because$ \\
$\therefore$
\end{tabular} & $\begin{array}{r}\because \\
\because \\
\because \\
\because \\
\because \\
i \\
10 \\
14 \\
7 \\
1 \\
\because \\
\because \\
\because \\
\because \\
\because \\
. \\
\end{array}$ & \begin{tabular}{|c|}
$\because$ \\
$\because$ \\
$\because$ \\
$\because$ \\
$\because$ \\
8 \\
8 \\
7 \\
4 \\
$\because$ \\
$\because$ \\
$\because$ \\
$\because$ \\
\end{tabular} & $\begin{array}{c}\because \because \\
\because \\
\because \\
\because \\
\because \\
\because \\
\because \\
\ddot{3} \\
2 \\
4 \\
1 \\
\because \\
\because \\
\because \\
\because \\
\end{array}$ & $\begin{array}{c}\because \\
\because \\
\because \\
\because \\
\because \\
\because \\
\because \\
\because 4 \\
3 \\
5 \\
2 \\
\because \\
\because \\
\because \\
\end{array}$ & $\begin{array}{c}\because \\
\because \\
\because \\
\ddot{1} \\
. \\
\because \\
\because \\
\because \\
\because \\
\ddot{5} \\
3 \\
2 \\
1 \\
. \\
\because \\
. \\
\end{array}$ & \begin{tabular}{|c|}
$\because$ \\
$\because$ \\
$\because$ \\
$\because$ \\
$\because$ \\
$\because$ \\
$\because$ \\
$\because$ \\
$\because 2$ \\
1 \\
1 \\
1 \\
$\because$ \\
\end{tabular} & $\begin{array}{c}\because \\
\because \\
\because \\
\because \\
\because \\
\because \\
\because \\
\because \\
\because \\
\because \\
\because \\
\because \\
\because \\
\because \\
\end{array}$ & $\begin{array}{l}\because \\
\because \\
\because \\
\because \\
\because \\
\because \\
\because \\
\because \\
\because \\
\because \\
\because \\
\because \\
\because \\
\because \\
\mathrm{i} \\
\end{array}$ & $\begin{array}{l}\because \\
\because \\
\because \\
\because \\
\because \\
\because \\
\because \\
\because \\
\because \\
\because \\
\because \\
\because \\
\because \\
\because \\
. \\
. \\
\end{array}$ & $\begin{array}{l}\because: \\
\because: \\
\because: \\
\because: \\
\because: \\
\because \\
\because \\
\because \\
\because \\
\because \\
\because \\
.\end{array}$ & $\begin{array}{c}\because \\
\because \\
\because \\
\because \\
\because 1 \\
\because \\
\because \\
\because \\
\because \\
\because \\
\because \\
\because \\
\because \\
\end{array}$ & 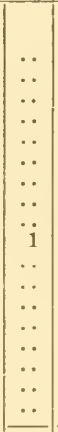 & $\begin{array}{r}1 \\
6 \\
11 \\
14 \\
24 \\
44 \\
46 \\
41 \\
30 \\
22 \\
12 \\
12 \\
11 \\
5 \\
2 \\
1 \\
1 \\
1\end{array}$ \\
\hline & 2 & 5 & 14 & 25 & 40 & 42 & 58 & 33 & 20 & 10 & 14 & & 5 & & & $\overline{.}$ & $\ldots$ & & 1 & 283 \\
\hline $\begin{array}{r}\mathrm{L} \\
6.6 \\
7.0 \\
7.4 \\
7.8 \\
8.2 \\
8.6 \\
9.0 \\
9.4 \\
9.8 \\
10.2\end{array}$ & 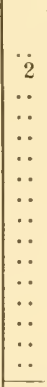 & 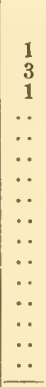 & 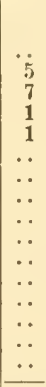 & 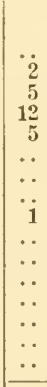 & $\begin{array}{r}\because \\
3 \\
12 \\
20 \\
4 \\
1 \\
\because \\
\because \\
\because \\
\because \\
\because \\
\because \\
\because \\
\end{array}$ & $\begin{array}{r}\because \\
\because \\
2 \\
7 \\
23 \\
8 \\
2 \\
\because \\
\because \\
\because \\
\because \\
\because \\
\because \\
\therefore\end{array}$ & $\begin{array}{r}\because . \\
\because \\
3 \\
19 \\
24 \\
8 \\
3 \\
1 \\
\because \\
\because \\
\because \\
\because . \\
. .\end{array}$ & $\begin{array}{r}. \\
\because \\
\because \\
\ddot{1} \\
2 \\
8 \\
16 \\
5 \\
1 \\
\because \\
\because \\
\because \\
\because \\
\because \\
\end{array}$ & \begin{tabular}{|c|}
$\because$. \\
$\because$ \\
$\because$ \\
$\mathrm{i}$ \\
$\because 2$ \\
9 \\
9 \\
4 \\
4 \\
$\because$ \\
$\because$ \\
$\because$ \\
$\because$ \\
\end{tabular} & $\begin{array}{l}. . \\
\because . \\
\ddot{.} \\
\ddot{1} \\
\dot{1} \\
\ddot{3} \\
3 \\
3 \\
. \\
. \\
. \\
.\end{array}$ & $\begin{array}{l}\because \\
\because \\
\because \\
\because \\
\because \\
\because \\
\ddot{4} \\
5 \\
. \\
\because \\
\because \\
\therefore\end{array}$ & \begin{tabular}{c}
$\because$ \\
$\because$ \\
\hdashline 1 \\
$\because$. \\
$\because$ \\
$\because$ \\
$\because$ \\
$\because 4$ \\
3 \\
4 \\
$\because$ \\
$\because$ \\
\end{tabular} & \begin{tabular}{c}
$\because$ \\
$\because$ \\
$\because$ \\
$\because$ \\
$\because$ \\
$\because$ \\
$\because$ \\
$\because$ \\
$\because$ \\
\hdashline 1 \\
2 \\
2 \\
$\because$ \\
. \\
\end{tabular} & $\begin{array}{l}\because \\
\because \\
\because \\
\because \\
\because \\
\therefore \\
\therefore \\
\therefore\end{array}$ & 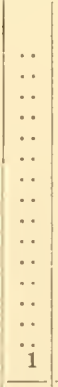 & 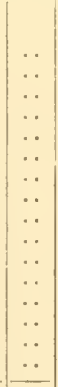 & $\begin{array}{c}\because \\
\because \\
\because . \\
\because . \\
\because \\
\because . \\
\because \\
\because \\
\because \\
\because \\
\because . \\
\end{array}$ & 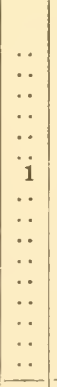 & $\begin{array}{l}\because . \\
\because . \\
\because . \\
\because . \\
\because \because \\
\mathrm{i} \\
\therefore \\
\because \\
\because \\
\because \\
\because \\
\end{array}$ & $\begin{array}{r}1 \\
12 \\
16 \\
28 \\
38 \\
48 \\
45 \\
35 \\
17 \\
13 \\
12 \\
9 \\
6 \\
2 \\
1 \\
1 \\
\end{array}$ \\
\hline Total.... & 2 & 5 & 14 & 25 & 40 & 42 & 58 & 33 & 20 & 10 & 14 & 12 & 5 & & 1 & .. &.. & 1 & 1 & 283 \\
\hline
\end{tabular}


TABle 31.

\begin{tabular}{|c|c|c|c|c|c|c|c|c|c|c|c|c|c|c|c|c|c|c|c|c|c|c|c|}
\hline \multirow[b]{2}{*}{$\begin{array}{l}\text { LENGTH of } \\
\text { Propodite. }\end{array}$} & \multicolumn{23}{|c|}{ Length of Propodite, Leg I. } \\
\hline & $\begin{array}{l}\overrightarrow{0} \\
\mathfrak{a} \\
0 \\
0\end{array}$ & 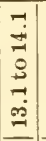 & 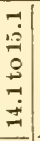 & $\begin{array}{c}-1 \\
\dot{0} \\
0 \\
0 \\
-1 \\
2\end{array}$ & 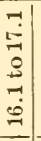 & 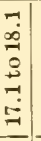 & 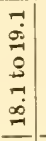 & 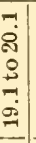 & 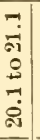 & 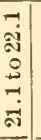 & 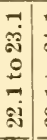 & 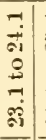 & 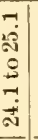 & 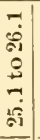 & \begin{tabular}{c}
-1 \\
5 \\
0 \\
0 \\
-1 \\
\hdashline
\end{tabular} & 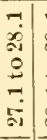 & 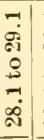 & 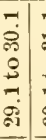 & 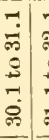 & 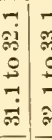 & 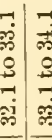 & 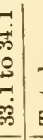 & 吾 \\
\hline 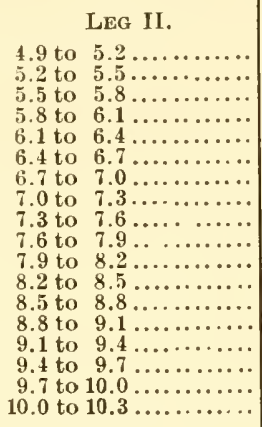 & $\begin{array}{l}\because \\
\because \because \\
\because \because \\
\because \\
\therefore \\
\because \\
\because \\
\because \\
\because \\
\because\end{array}$ & $\begin{array}{c}1 \\
2 \\
1 \\
\because \\
\because \\
\because \\
\because \\
\because \\
\because \\
\because \\
\because \\
\because \\
\because \\
\because\end{array}$ & 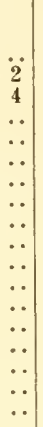 & 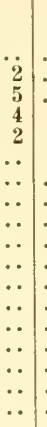 & $\begin{array}{c}\because \ddot{ } \\
\ddot{9} \\
9 \\
1 \\
. \\
\because \\
\because \\
\because \\
\because \\
\because \\
\because \\
\because \\
\because \\
\because\end{array}$ & $\begin{array}{l}\because \ddot{ } \\
\because \\
8 \\
8 \\
11 \\
5 \\
\because \\
\because \\
\therefore \\
\because \\
\because \\
\because \\
\because \\
\because \\
\therefore\end{array}$ & $\begin{array}{r}\because \\
\because \\
\ddot{4} \\
16 \\
9 \\
3 \\
\ddot{2} \\
\because \\
\because \\
\because \\
\because \\
\because \\
\because \\
\because\end{array}$ & $\begin{array}{r}\because \\
\because \\
\mathrm{i} \\
\mathrm{i2} \\
18 \\
4 \\
\mathbf{2} \\
\therefore \\
\because \\
\because \\
\because \\
\because \\
\because\end{array}$ & $\begin{array}{r}\because \\
\because \because \\
\because \\
1 \\
4 \\
11 \\
13 \\
2 \\
\because \\
\because \\
\because \\
\because \\
\because \\
\because \\
\therefore\end{array}$ & $\begin{array}{c}\because \\
\because \\
\because \\
\because \\
\ddot{2} \\
19 \\
8 \\
\because \\
\because \\
\because \\
\because \\
\because \\
\because \\
\because\end{array}$ & 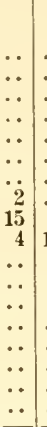 & 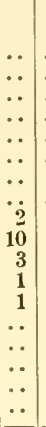 & $\begin{array}{c}1 \\
6 \\
4 \\
. \\
\because \\
\because \\
\because \\
\because \\
.\end{array}$ & 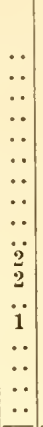 & $\begin{array}{c}\because \\
\because \\
\because \\
\because \\
\because \\
\because \\
\because \\
1 \\
2 \\
6 \\
\because \\
\because \\
\because \\
\because\end{array}$ & 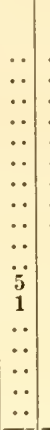 & $\begin{array}{l}\because \\
\because \\
\because \\
\because \\
\because \\
\because \\
\because \\
\ddot{1} \\
1 \\
3 \\
1 \\
\because \\
\because \\
\therefore\end{array}$ & 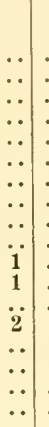 & $\begin{array}{l}\because \\
\because \\
\because \\
\because \\
\because \\
: \\
\because \\
\therefore \\
\therefore \\
\therefore \\
\ddot{1} \\
\ddot{1} \\
1 \\
1 \\
\therefore\end{array}$ & 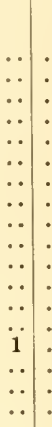 & 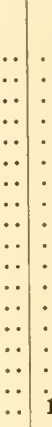 & $\begin{array}{l}\because \\
\because \\
\because \\
\because \\
\because \\
\because \\
\because \\
\because \\
\because \because \\
\because \\
\because .\end{array}$ & $\begin{array}{r}1 \\
6 \\
11 \\
14 \\
24 \\
44 \\
46 \\
41 \\
30 \\
22 \\
12 \\
12 \\
11 \\
5 \\
2 \\
1 \\
1 \\
1\end{array}$ \\
\hline Total........ & 1 & 4 & 6 & 13 & 19 & 24 & 34 & 37 & 31 & 29 & 21 & 17 & 12 & 5 & 9 & 6 & 6 & $\overline{4}$ & 3 & 1 & .. & & 283 \\
\hline 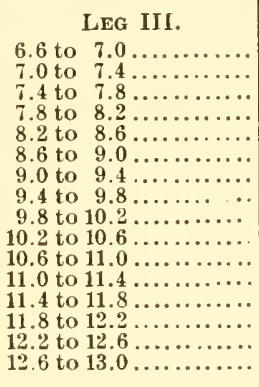 & $\begin{array}{l}1 \\
\because \\
\because \\
\because \\
\therefore \\
\because \\
\therefore \\
\therefore \\
\therefore \\
\because \\
\therefore \\
\therefore\end{array}$ & $\begin{array}{c}3 \\
1 \\
\because \\
\because \\
\because \\
\because \\
\because \\
\because \\
\because \\
\because \\
\because \\
\because \\
\end{array}$ & $\begin{array}{l}1 \\
1 \\
4 \\
. . \\
. \\
. \\
. \\
. \\
. \\
. \\
\therefore \\
\therefore \\
. \\
.\end{array}$ & $\begin{array}{l}4 \\
6 \\
3 \\
: \because \\
\because \\
\because \\
\because \\
\because \\
\because \\
\because \\
\because \\
\because \\
\because\end{array}$ & $\begin{array}{c}2 \\
4 \\
9 \\
3 \\
1 \\
\because . \\
\because \\
\because \\
\because \\
\because \\
\because \\
\because \\
\because\end{array}$ & $\begin{array}{r}1 \\
10 \\
8 \\
3 \\
2 \\
\because \\
\because \because \\
\because \\
\because \\
\because \\
\because \\
\because\end{array}$ & $\begin{array}{c}\because \\
\because \\
13 \\
11 \\
3 \\
2 \\
2 \\
\because \\
\because \\
\because \\
\because \\
\because \\
\because \\
\end{array}$ & \begin{tabular}{r}
$\because$ \\
$\mathrm{i}$ \\
1 \\
12 \\
15 \\
6 \\
1 \\
1 \\
\hdashline \\
$\because$ \\
$\because \because$ \\
$\because$ \\
$\because$
\end{tabular} & $\begin{array}{c}\because \\
\because \\
\ddot{1} \\
13 \\
15 \\
1 \\
1 \\
\therefore \\
\because \\
\because \\
\because \\
\because \\
\therefore\end{array}$ & $\begin{array}{c}\because \\
\because \\
\because \\
\ddot{4} \\
15 \\
10 \\
\because \\
\because \\
\because \\
\because \\
\because\end{array}$ & 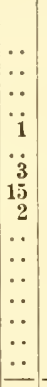 & 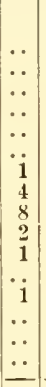 & $\begin{array}{c}\because \\
\because \\
\because \\
\ddot{1} \\
\ddot{2} \\
\tilde{5} \\
4 \\
\ddot{y} \\
\because \\
\because \\
\because\end{array}$ & 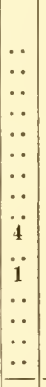 & 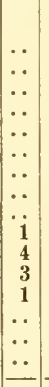 & \begin{tabular}{l|}
$\because$ \\
. \\
. \\
$:$ \\
. \\
$:$ \\
$\ddot{1}$ \\
4 \\
1 \\
$\therefore$ \\
$\therefore$ \\
.
\end{tabular} & 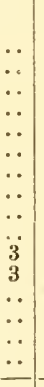 & 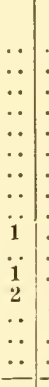 & 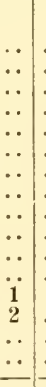 & 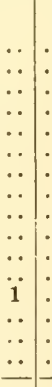 & 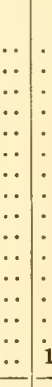 & $\begin{array}{l}\because \\
\because \\
\because \\
\because \\
\because \\
\because \\
\because \\
\because \\
\because \\
\because \\
\\
\end{array}$ & $\begin{array}{r}1 \\
12 \\
16 \\
28 \\
38 \\
48 \\
45 \\
35 \\
17 \\
13 \\
12 \\
9 \\
6 \\
2 \\
1 \\
1\end{array}$ \\
\hline Total............ & 1 & 4 & 6 & 13 & 19 & 24 & 34 & 37 & 31 & 29 & 21 & 17 & 12 & 5 & 9 & 6 & 6 & 4 & 3 & 1. & .. & & 283 \\
\hline
\end{tabular}

Table 32.

\begin{tabular}{|c|c|c|c|c|c|c|c|c|c|c|c|c|c|c|c|c|c|c|c|}
\hline \multirow[b]{2}{*}{$\begin{array}{l}\text { LENGTH OF } \\
\text { PROPODITE. }\end{array}$} & \multicolumn{19}{|c|}{ Length of Propodite, Leg II. } \\
\hline & 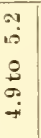 & 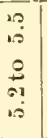 & 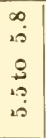 & $\begin{array}{c}\overrightarrow{0} \\
0 \\
\infty \\
\dot{0} \\
20\end{array}$ & $\begin{array}{l}\overrightarrow{0} \\
\dot{0} \\
\stackrel{\Xi}{0} \\
\overrightarrow{0}\end{array}$ & $\begin{array}{l}ت: \\
0 \\
\dot{0} \\
+ \\
\dot{0}\end{array}$ & $\begin{array}{l}\stackrel{0}{0} \\
\therefore \\
\stackrel{8}{+} \\
\dot{0}\end{array}$ & 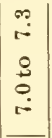 & 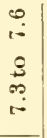 & 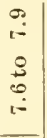 & 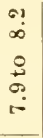 & 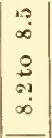 & \begin{tabular}{c|}
$\infty$ \\
$\infty$ \\
$\infty$ \\
0 \\
$\dot{3}$ \\
$\infty$ \\
$\infty$
\end{tabular} & $\begin{array}{c}-1 \\
0 \\
5 \\
+ \\
\infty \\
\infty\end{array}$ & $\begin{array}{l}\vec{\sigma} \\
\dot{\sigma} \\
\dot{0} \\
\vec{\sigma}\end{array}$ & $\begin{array}{l}1 \\
0 \\
0 \\
\dot{0} \\
\ddot{0}\end{array}$ & $\begin{array}{l}\stackrel{0}{\circ} \\
\stackrel{\leftrightarrow}{\circ} \\
\stackrel{0}{0}\end{array}$ & $\begin{array}{l}\infty \\
0 \\
0 \\
\dot{0} \\
0 \\
\dot{0}\end{array}$ & \\
\hline 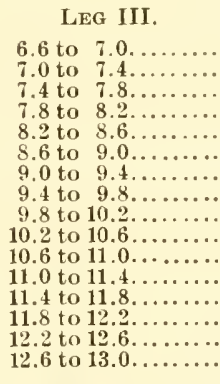 & $\begin{array}{l}1 \\
\because . \\
\because \\
\because . \\
\because \\
\because \because \\
\because \because \\
\because \because \\
\because \because \\
\because \because \\
\because \because \\
\end{array}$ & $\begin{array}{c}1 \\
3 \\
2 \\
\because \\
\because \\
\because \\
\because \\
\because \\
\because \\
\because \\
\because \\
\because \\
\because \\
\because \\
\because \\
\end{array}$ & $\begin{array}{c}2 \\
8 \\
1 \\
\because \\
\because \\
\because \\
\because \\
\because \\
\because \\
\because \\
\because \\
\because \\
.\end{array}$ & $\begin{array}{c}4 \\
4 \\
5 \\
1 \\
\because \\
\because \\
\because \\
\because \\
\because \\
\because \\
\because \\
\because \\
.\end{array}$ & $\begin{array}{r}2 \\
1 \\
15 \\
3 \\
2 \\
1 \\
1 \\
\because . \\
\because \because \\
\because \because \\
\because \because \\
\because \because \\
\because \\
\end{array}$ & 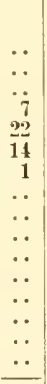 & $\begin{array}{l}\because \\
1 \\
\ddot{9} \\
25 \\
11 \\
\because \\
\because \\
\because \\
\because \\
\because \\
\because \\
\because \\
\end{array}$ & $\begin{array}{r}\because \\
\because \\
\because \\
6 \\
6 \\
26 \\
7 \\
1 \\
\because \\
\because \\
\because \\
\because \\
\because \\
\end{array}$ & $\begin{array}{c}\because \\
\because \\
\because \\
1 \\
1 \\
5 \\
20 \\
3 \\
\because \\
\because \\
\because \\
\because \\
\because \\
.\end{array}$ & 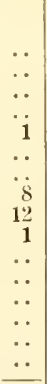 & $\begin{array}{c}\because \\
\because \\
\because \\
\because \\
\ddot{1} \\
\ddot{i} \\
9 \\
\ddot{1} \\
\because \\
\because \\
\because \\
\end{array}$ & 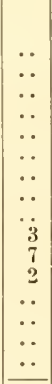 & 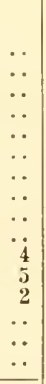 & $\begin{array}{l}\because \\
\because . \\
\because \\
\because \\
\because \\
\because \\
\because \\
\ddot{1} \\
1 \\
3 \\
\because \\
\because \\
.\end{array}$ & $\begin{array}{l}\because . \\
\because . \\
\because \\
\because . \\
\because . \\
\because . \\
\because \\
1 \\
1 \\
\because . \\
\end{array}$ & 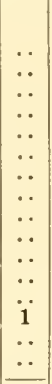 & 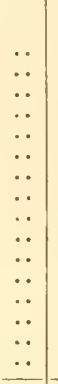 & $\begin{array}{l}\because \\
\because \\
\because \\
\because \\
\because \\
\because \\
\because \\
\because \\
\because \\
\because \\
\because \\
1\end{array}$ & $\begin{array}{r}1 \\
12 \\
16 \\
28 \\
3 \times \\
48 \\
4.5 \\
35 \\
17 \\
13 \\
12 \\
9 \\
6 \\
2 \\
1 \\
\mathrm{i} \\
\end{array}$ \\
\hline Total....... & 1 & 6 & 11 & 14 & 24 & 44 & 46 & 41 & 30 & 22 & 12 & 12 & 11 & 5 & 2 & 1 & .. & 12 & $3 \times 3$ \\
\hline
\end{tabular}




\section{LITERATURE CITED.}

Clawson, A. B.

1905. Some results of a study of correlation in the crayfish. Seventh Report Mich. Acad. Sci., pp. 103-108. 1905.

DAvenport, C. B.

1903. Quantitative studies on the evolution of Pecten. III. Comparison of Pecten opercularis from three localities in the British Isles. Proc. Amer. Acad. Arts and Sci., vol. xxxix, pp. 123-159. 1903.

Driesch, H.

1901. Die organischen Regulationen. Vorbereitungen zu einer Theorie des Lebens.

Duncker, G. Leipzig (Engelmann), 1901, $8^{\circ}$, pp. $x \mathrm{v}+228$.

1900. On variation in the rostrum of Palaemonetes vulgaris Herbst. Amer. Nat., vol. xxxiv, pp. 621-633. 1900.

1903. Ueber Asymmetrie bei "Gelasimus pugilator" Latr. Biometrika, vol. II, pp. 307-320. 1903.

FawcetT, C. D.

1902. A second study of the variation and correlation of the human skull, with special reference to the Naqada crania. Biometrika, vol. r, pp. 403-467,

Faxon, W. pls. IV-X. 1902.

1884. On the so-called Dimorphism in the genus Cambarus. Amer. Jour. Sci., vol. $27, \mathrm{pp} .42-44.1884$.

GaLton, F.

1897. Note to the Memoir by Professor Karl Pearson, F. R. S., on spurious correlation. Proc. Roy. Soc., vol.60, pp. 498-502. 1897.

\section{HAGEN, H. A.}

1870. Monograph of the North American Astacidae. Ill. Cat. Mus. Comp. Zool.

HARRIS, J. A. Harvard Coll. 1870. Vol. 3, pp. 1-110, 11 plates.

1901. Observations on the so-called Dimorphism in the males of Cambarus Erichson. Zool. Anz., Bd. 24, pp. 683-689. 1901.

Lewenz, M. A., and Whiteley, M. A.

1902. Data for the problem of evolution in man. A second study of the variability and correlation of the hand. Biometrika, vol. I, pp. 345-360. 1902.

Macdonell, W. R.

1904. A study of the variation and correlation of the human skull, with special reference to English crania. Biometrika, vol. III, pp. 191-244, pls. I-L. 1904.

Pfart, R.

1906. Variation in Chilomonas under favorable and unfavorable conditions. Biometrika, vol. v, pp. 53-72.

1907. A biometrical study of conjugation in Paramecium. Biometrika, vol. v, pp. 213-297.

Pfarl, R. (with the assistance of Olive M. Pepper and Florence J. Hagle).

1907a. Variation and differentiation in Ceratophyllum. Carnegie Institution of Washington Publication No. 58.

Pearson, K.

1897. Mathematical contributions to the theory of evolution. On a form of spurious correlation which may arise when indices are used in the measurement of organs. Proc. Roy. Soc., vol.60, pp. 489-498. 1897. 


\section{VARIATION AND CORRELATION IN THE CRAYFISH.}

Pearson, K.

1902. Mathematical contributions to the theory of evolution. XI. On the influence of natural selection on the variability and correlation of organs. Phil. Trans., vol. 200A, pp. 1-66. 1902.

Schuster, E. H. J.

1903. Variation in "Eupagurus prideauxi" (Heller). Biometrika, vol. II, pp. 191-210. 1903.

WARren, E.

1897. An investigation on the variability of the human skeleton, with especial reference to the Naqada race discovered by Professor Flinders Petrie in his explorations in Egypt. Phil. Trans., vol. 189в, pp. 125-227. 1897.

1902. Variation and inheritance in the parthenogenetic generations of the aphis "Hyalopterus trirhodus" (Walker). Biometrika, vol. I, 129-154. 1902.

YERKES, R. M.

1901. A study of variation in the fiddler crab, Gelasimus pugilator Latr. Proc. Amer. Acad. Arte and Sci., vol. xxxvi, pp. 417-442. 1901. 









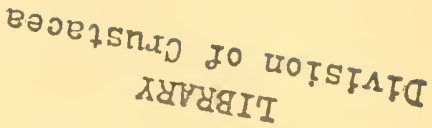

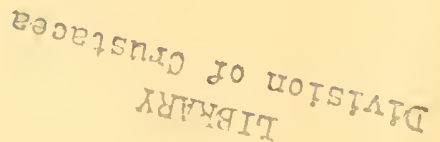



$\{, 3,3,3,35$ 3. 3 - $3,-3,-3=5$ $\left\{\begin{array}{l}3 \\ 3\end{array}\right.$

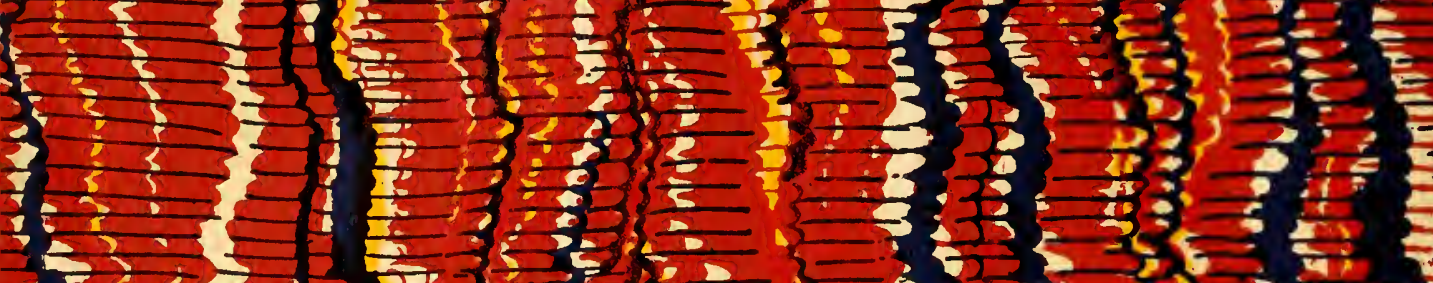
ह : $\{, 5,3,5,5$ 4. 1 13 33 $353,33=3$

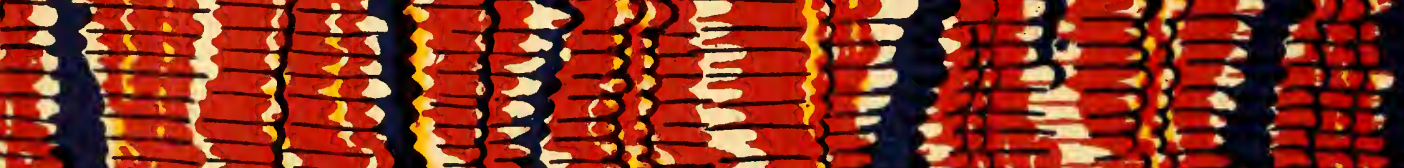

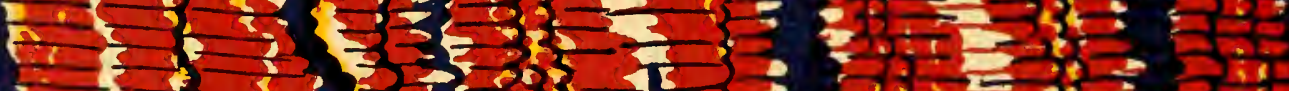
3 303

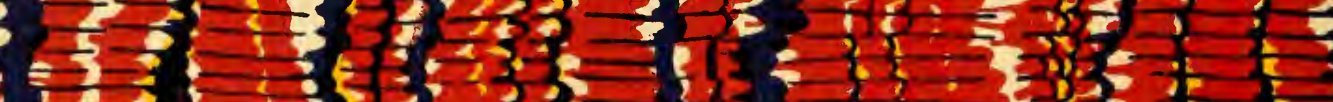

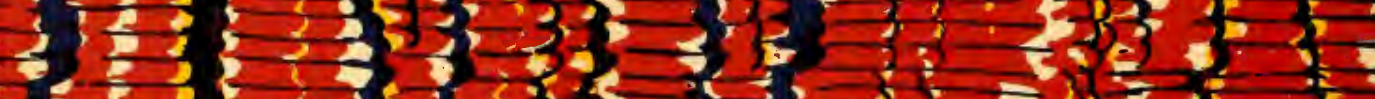

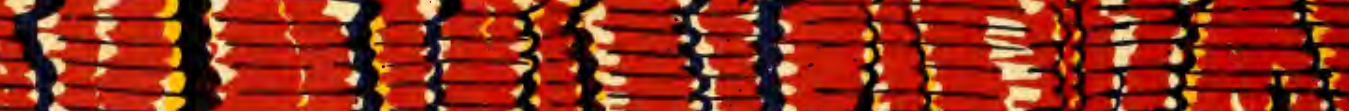

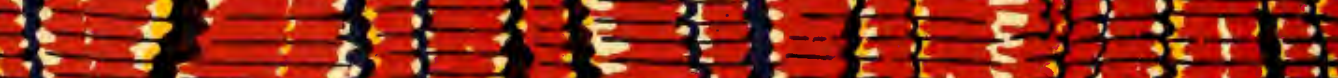

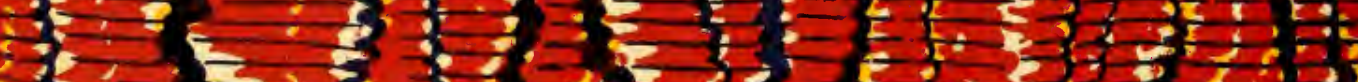

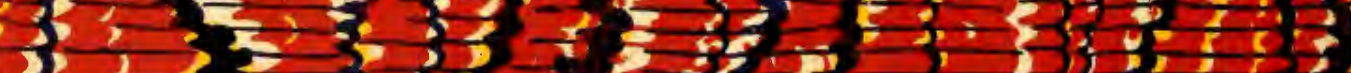

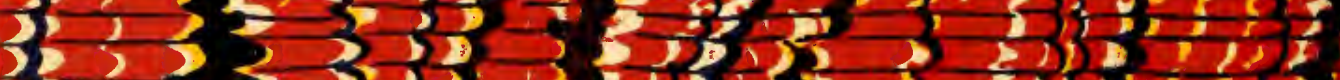

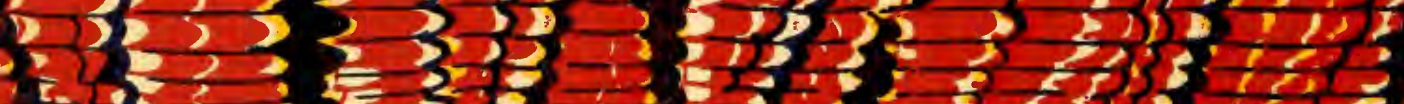

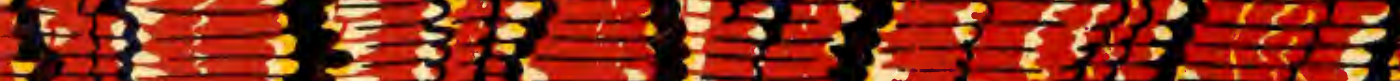

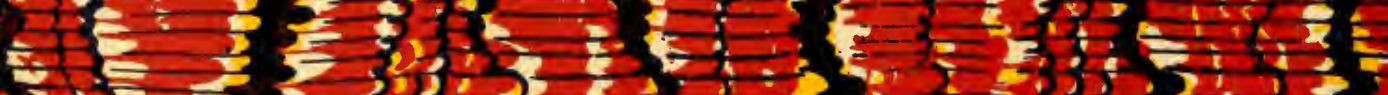

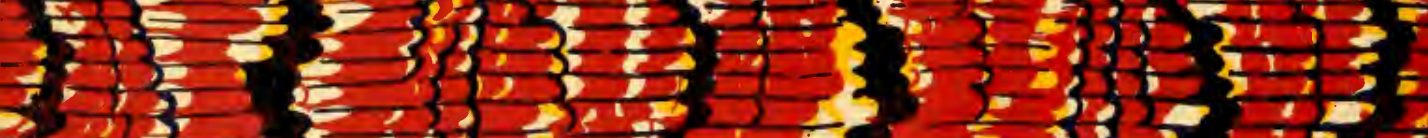

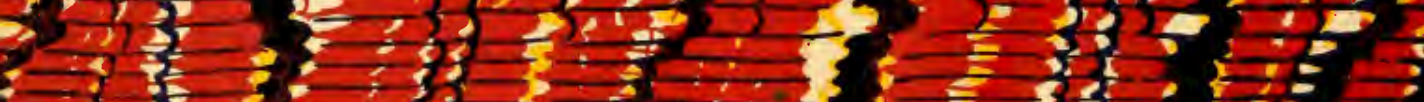

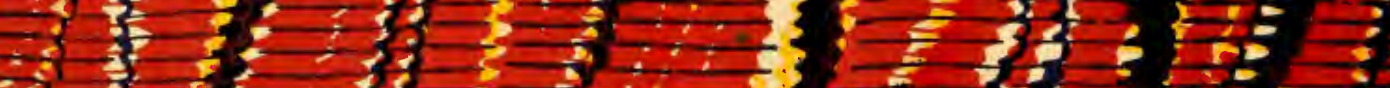

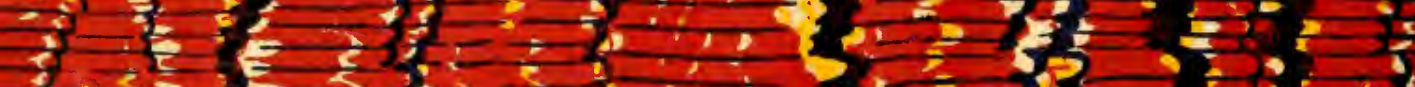

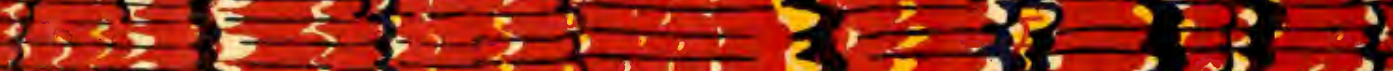

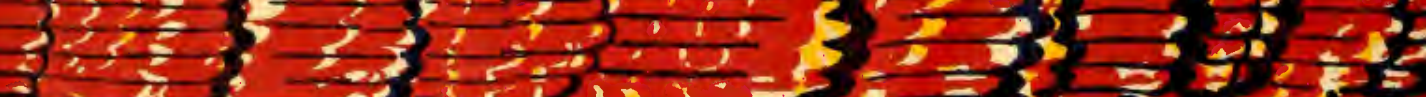

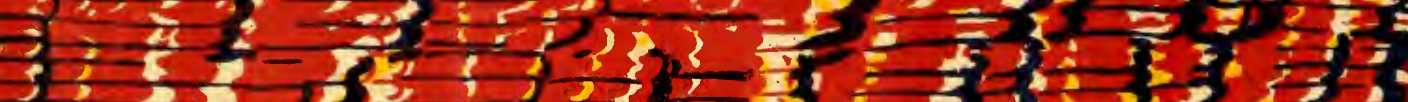

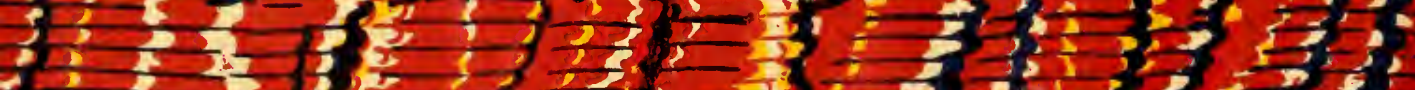

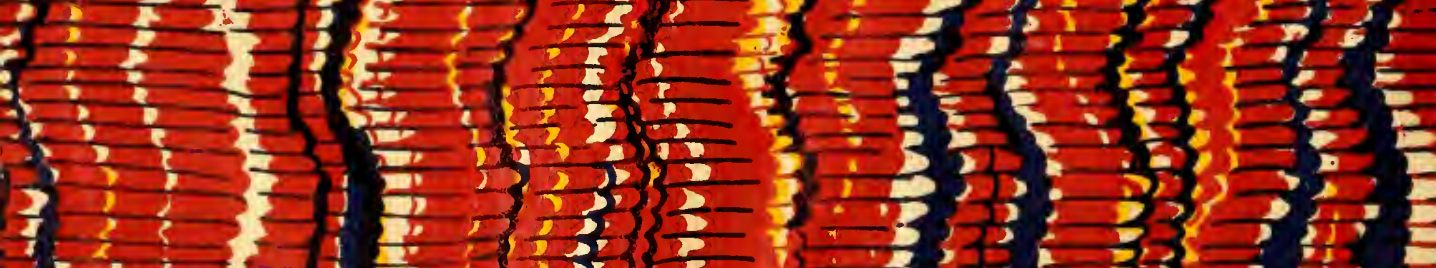


$\{, 3,5,3$

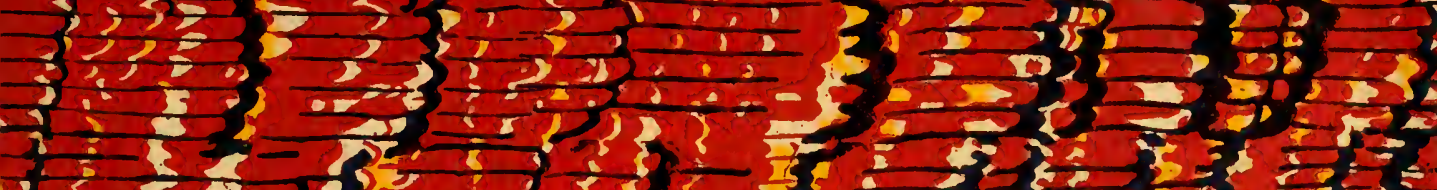

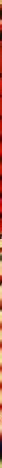

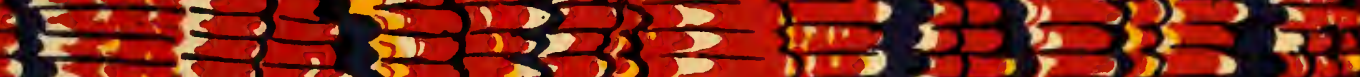

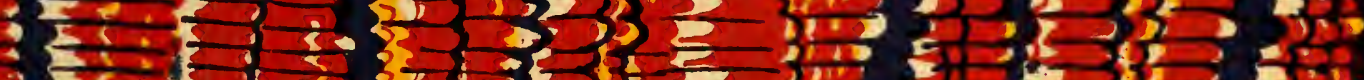

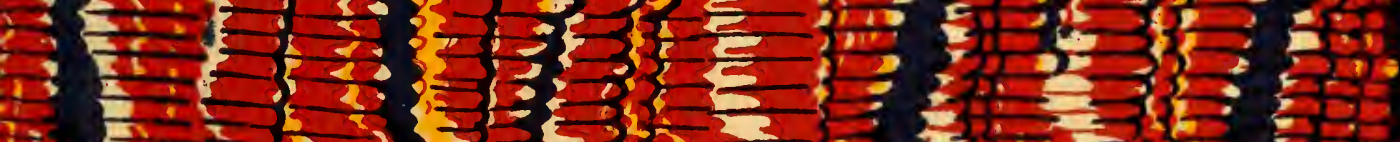

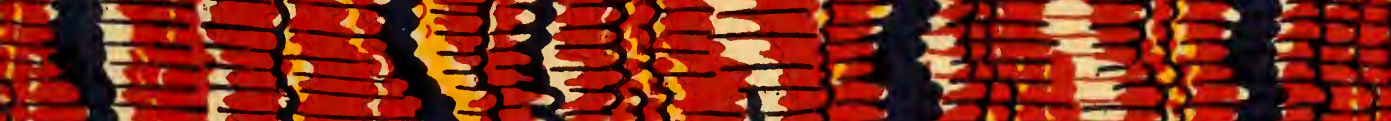
in

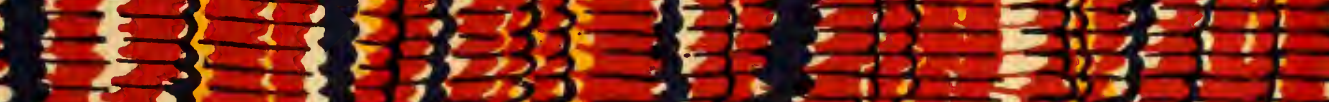

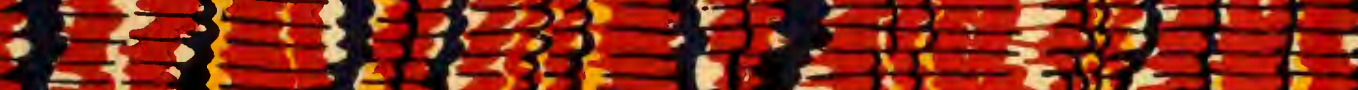

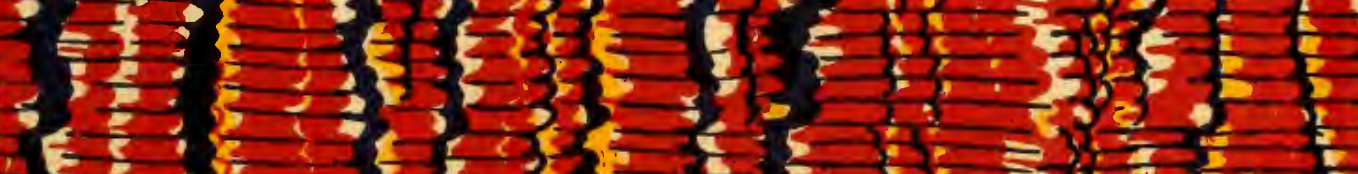

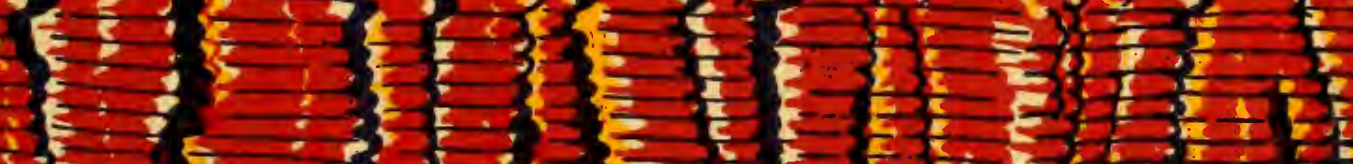
6:5

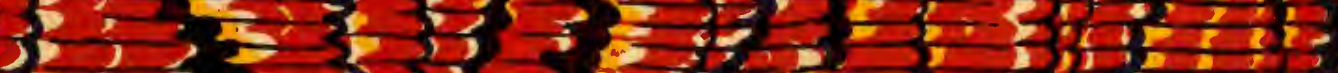

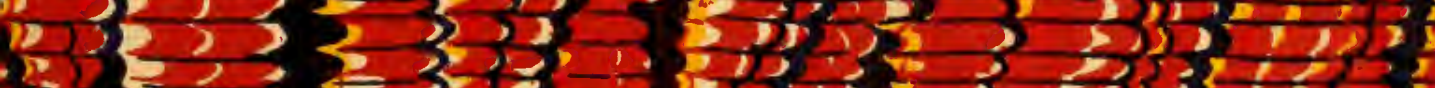

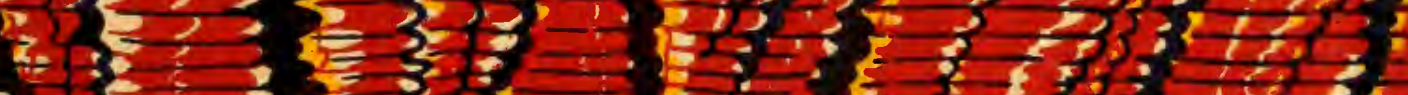

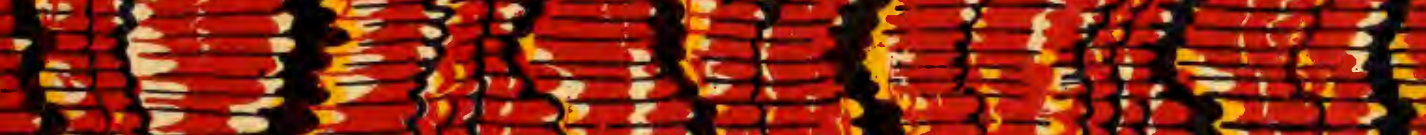

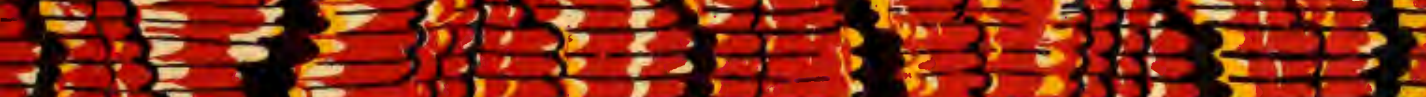

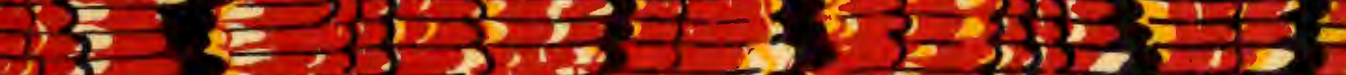

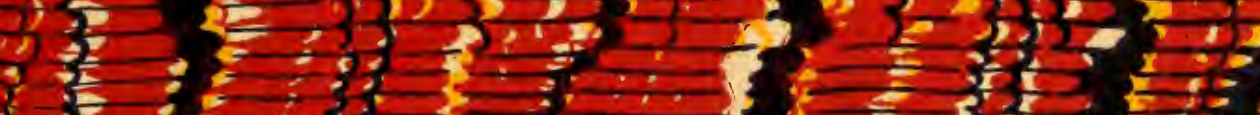

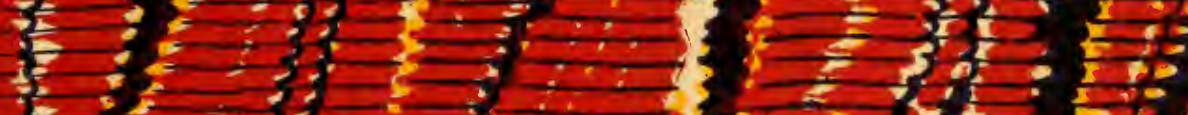
色位

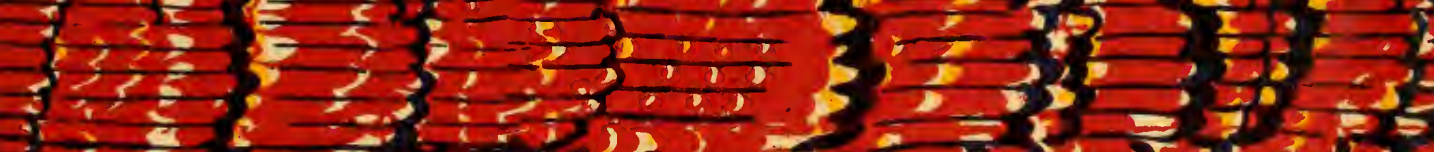

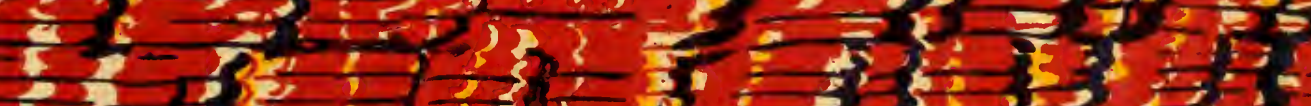

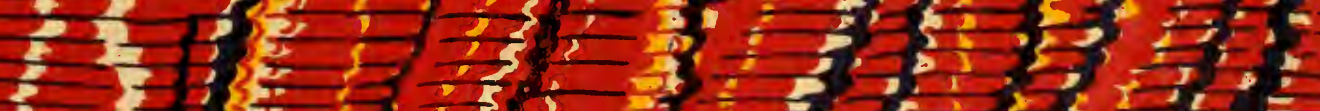

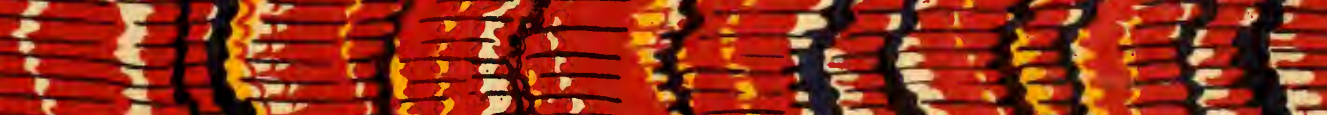

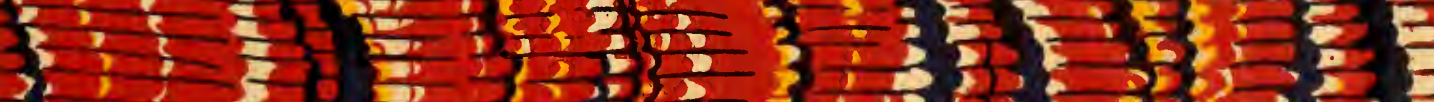

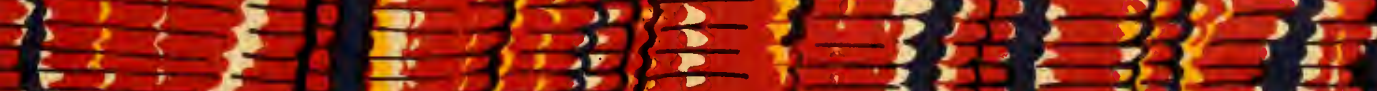

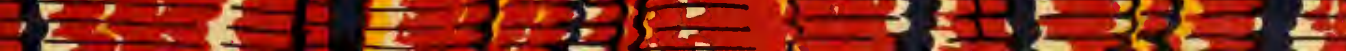


